Nevada

Environmental

Restoration

Project

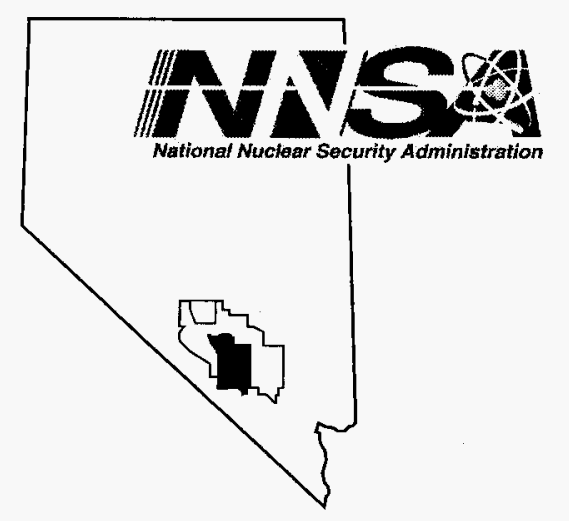

\title{
Closure Report for Corrective Action Unit 140: Waste Dumps, Burn Pits, and Storage Area, Nevada Test Site, Nevada
}

Controlled Copy No.:

Revision: 0

August 2005

Environmental Restoration

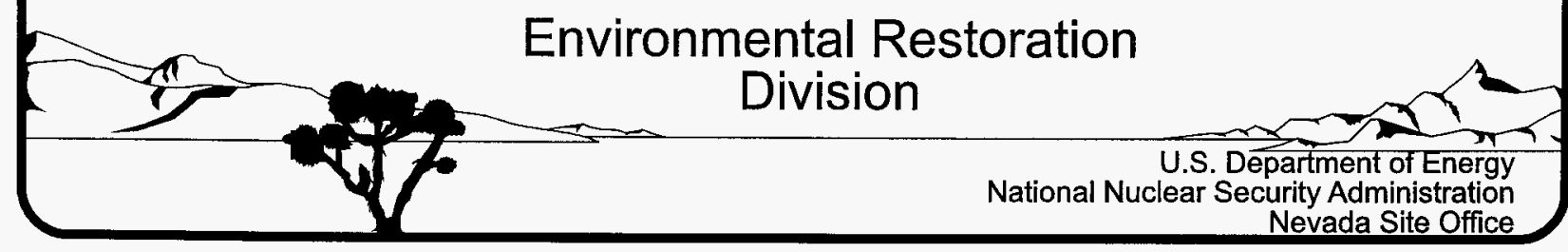




\section{DISCLAIMER}

This report was prepared as an account of work sponsored by an agency of the U.S. Government. Neither the U.S. Government nor any agency thereof, nor any of their employees, nor any of their contractors, subcontractors or their employees, makes any warranty or representation, express or implied, or assumes any legal liability or responsibility for the accuracy, completeness, or usefulness of any information, apparatus, product, or process disclosed, or represents that its use would not infringe privately own rights. Reference herein to any specific commercial product, process, or service by trade name, trademark, manufacturer, or otherwise, does not necessarily constitute or imply its endorsement, recommendation, or favoring by the U.S. Government or any agency thereof. The views and opinions of authors expressed herein do not necessarily state or reflect those of the U.S. Government or any agency thereof.

This report has been reproduced directly from the best available copy.

Available for sale to the public from:

U.S. Department of Commerce

National Technical Information Service

5285 Port Royal Road

Springfield, VA 22161-0002

Telephone: (800) 553-6847

Fax: (703) 605-6900

E-mail: orders@ntis.gov

Online ordering: http:/www.ntis.gov/ordering.htm

Available electronically at http://www.osti.gov/bridge.

Available for a processing fee to the U.S. Department of Energy and its contractors, in paper, from:

U.S. Department of Energy

Office of Scientific and Technical Information

P.O. Box 62

Oak Ridge, TN 37831-0062

Telephone: (865) 576-8401

Fax: (865) 576-5728

E-mail: reports@adonis.osti.gov 


\title{
CLOSURE REPORT FOR CORRECTIVE ACTION UNIT 140: WASTE DUMPS, BURN PITS, AND STORAGE AREA, NEVADA TEST SITE, NEVADA
}

\author{
U.S. Department of Energy \\ National Nuclear Security Administration \\ Nevada Site Office \\ Las Vegas, Nevada
}

Controlled Copy No.

Revision: 0

August 2005 
THIS PAGE INTENTIONALLY LEFT BLANK 


\section{CLOSURE REPORT \\ FOR CORRECTIVE ACTION UNIT 140: WASTE DUMPS, BURN PITS, AND STORAGE AREA, NEVADA TEST SITE, NEVADA}

Approved By: $\frac{\text { Sabui Curtis }}{\text { Sabine Curtis, Acting Project Manager }}$ Date: $8 / 9 / 05$ Industrial Sites Project

Approved By:

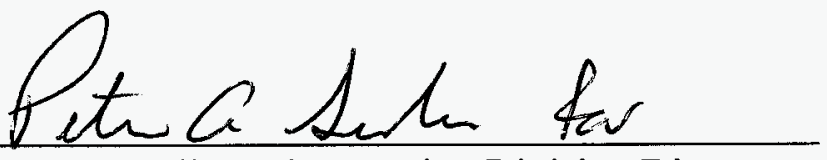

Janet Appenzeller-Wing, Acting Division Director Date: $8 / 9 / 2005$ Environmental Restoration Division 
THIS PAGE INTENTIONALLY LEFT BLANK 


\section{TABLE OF CONTENTS}

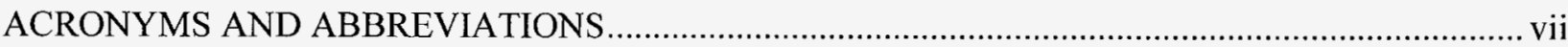

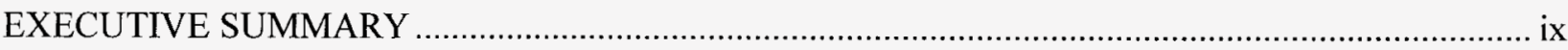

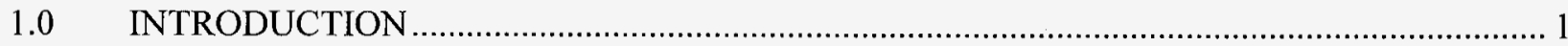

$1.1 \quad$ PURPOSE

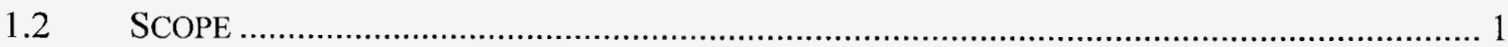

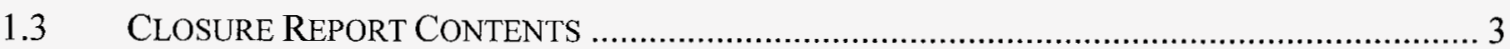

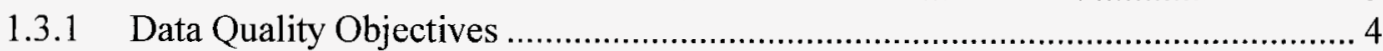

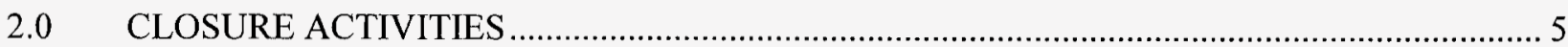

2.1 DESCRIPTION OF CORRECTIVE ACTION ACTIVITIES …............................................ 5

2.1.1 Preplanning and Site Preparation ............................................................. 5

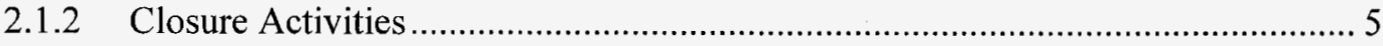

2.1.2.1 CAS 05-08-01, Detonation Pits.................................................... 5

2.1.2.2 CAS 05-08-02, Debris Pits.......................................................... 7

2.1.2.3 CAS 05-17-01, Hazardous Waste Accumulation Site (Buried) .......... 7

2.1.2.4 CAS 05-19-01, Waste Disposal Site ............................................... 7

2.1.2.5 CAS 05-23-01, Gravel Gertie …................................................... 7

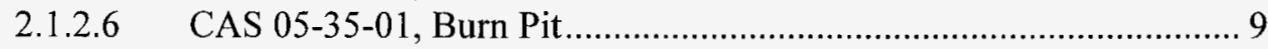

2.1.2.7 CAS 05-99-04, Burn Pit................................................................ 9

2.1.2.8 CAS 22-99-04, Radioactive Waste Dump .................................... 9

2.1.2.9 CAS 23-17-01, Hazardous Waste Storage Area ............................... 9

2.2 DEVIATIONS FROM CORRECTIVE ACTION PLAN AS APPROVED ..................................... 9

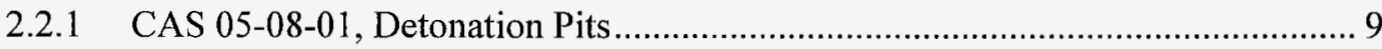

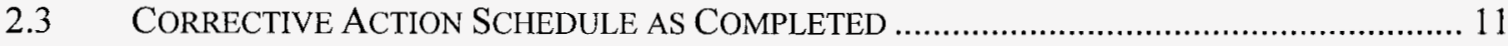

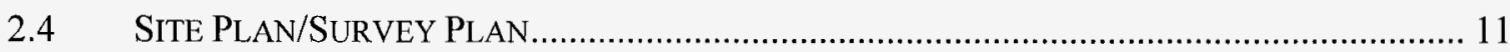

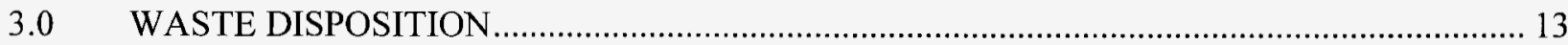

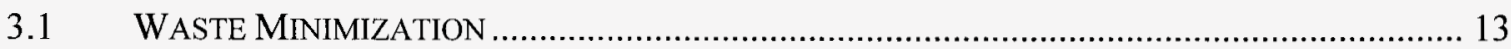

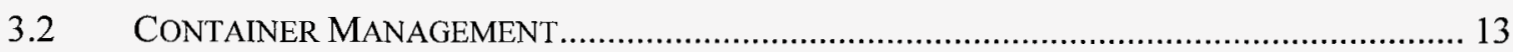

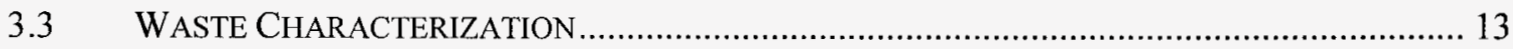

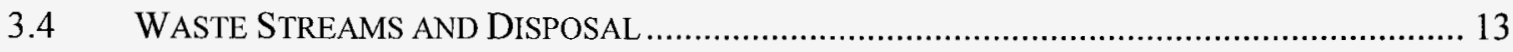

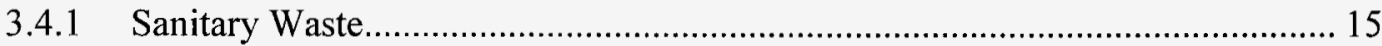

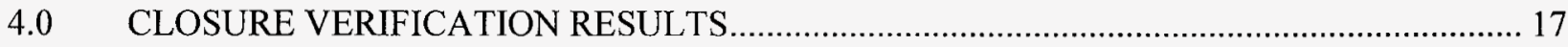

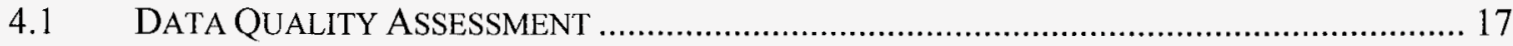

4.1.1 Quality Assurance/Quality Control Procedures ................................................ 17

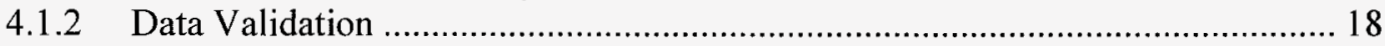

4.1.3 Conceptual Site Models.................................................................................. 18

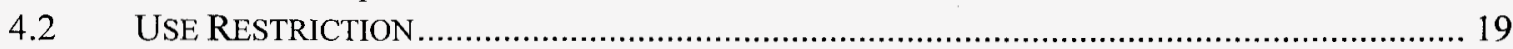

4.2.1 CAS 05-23-01, Gravel Gertie ................................................................... 19

4.2.2 CAS 23-17-01, Hazardous Waste Storage Area.................................................. 19

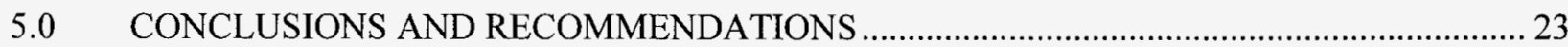

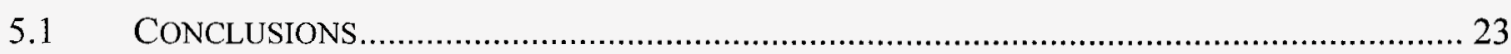

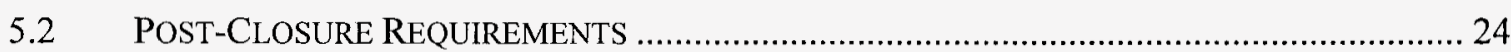

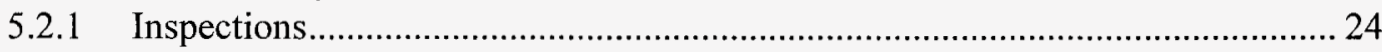

5.2.1.1 CAS 05-23-01, Gravel Gertie ................................................. 24 


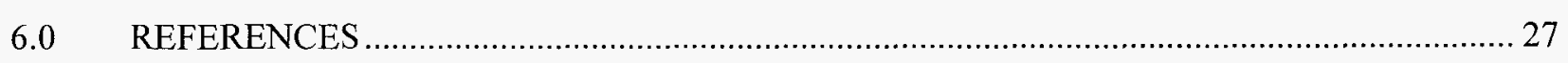

\section{FIGURES}

Figure 1. CAU 140 Site Location Map ………………................................................... 2

Figure 2. CAS 05-08-01, Detonation Pits, Verification Sample Location .......................... 6

Figure 3. CAS 05-23-01, Gravel Gertie, USE Restriction Boundary …….......................... 8

Figure 4. CAS 23-17-01, Hazardous Waste Storage AREa, Use Restriction Boundary 10

Figure 5. CAU 140, CAS 05-23-01, Gravel Gertie, Use Restriction Sign ........................... 20

Figure 6. CAU 140, CAS 23-17-01, HAZARdous WASTE Storage AREa, LANDFILl, USE

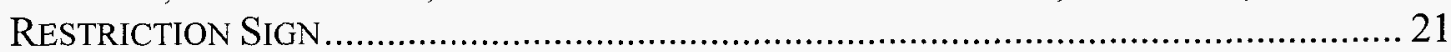

Figure 7. CAU 140, CAS 23-17-01, Hazardous Waste Storage AREa, TPH-IMPaCted AREA, USE RESTRICTION SIGN ....................................................................... 22

\section{TABLES}

Table 1. Summary of CAU 140 Closure Activities ............................................................

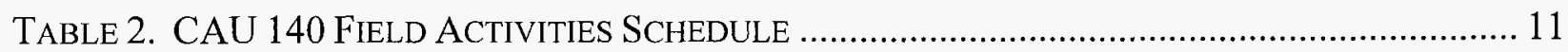

TABle 3. CAU 140 Waste Characterization SAmPles Collected ………........................... 14

TABLE 4. CAU 140 Verification SAMPLE Results ................................................................. 17

\section{APPENDICES}

APPENDIX A - DATA QUALITY OBJECTIVES

APPENDIX B - ClOSURE CERTIFICATION

APPENDIX C - As-BUILT DOCUMENTATION

APPENDIX D - SAMPLE ANALYTICAL RESULTS

APPENDIX E - WASTE DisPOSITION DOCUMENTATION

APPENDIX F - MODIFICATIONS TO THE POST-CLOSURE PlaN

APPENDIX G - USE RESTRICTION DOCUMENTATION

APPENDIX H - Site CLOSURE PHOTOGRAPHS

ApPendix I - NeVAda EnVIRONMENTAL Restoration Project Document ReVIEW SheET

APPENDIX J - NATIONAL ENVIRONMENTAL POLICY ACT CHECKLIST

LIBRARY DISTRIBUTION LIST 


\section{ACRONYMS AND ABBREVIATIONS}

bgs below ground surface

BMP Best Management Practice

BN Bechtel Nevada

CADD Corrective Action Decision Document

CAIP Corrective Action Investigation Plan

CAP Corrective Action Plan

CAS(s) Corrective Action Site(s)

CAU Corrective Action Unit

COC(s) Contaminant(s) of Concern

CR Closure Report

CSM(s) Conceptual Site Model(s)

DOE U.S. Department of Energy

DOE/NV U.S. Department of Energy, Nevada Operations Office

DOT U.S. Department of Transportation

DQO(s) Data Quality Objective(s)

EPA U.S. Environmental Protection Agency

ER Environmental Restoration

FFACO Federal Facility Agreement and Consent Order

$\mathrm{ft} \quad$ foot (feet)

$\mathrm{m} \quad$ meter(s)

$\mathrm{m}^{3} \quad$ cubic meter(s)

$\mathrm{mg} / \mathrm{kg} \quad$ milligram(s) per kilogram

NA not applicable

NAC Nevada Administrative Code

ND Not Detected

NDEP Nevada Division of Environmental Protection

NNSA/NSO U.S. Department of Energy, National Nuclear Security Administration Nevada Site Office

NNSA/NV U.S. Department of Energy, National Nuclear Security Administration Nevada Operations Office

NTS Nevada Test Site 


$\begin{array}{ll}\text { PAL(s) } & \text { Preliminary Action Level(s) } \\ \text { pCi/g } & \text { picocuries per gram } \\ \text { QA } & \text { Quality Assurance } \\ \text { QAPP } & \text { Quality Assurance Project Plan } \\ \text { QC } & \text { Quality Control } \\ \text { SDG } & \text { Sample Delivery Group } \\ \text { Th-234 } & \text { Thorium-234 } \\ \text { TPH } & \text { Total Petroleum Hydrocarbons } \\ \text { WGS } & \text { Waste Generator Services } \\ \text { XRF } & \text { X-Ray Fluorescence } \\ \text { yd }^{3} & \text { cubic yard(s) }\end{array}$


Corrective Action Unit (CAU) 140, Waste Dumps, Burn Pits, and Storage Area, is identified in the Federal Facility Agreement and Consent Order (FFACO) of 1996. CAU 140 is located in Areas 5, 22, and 23 of the Nevada Test Site, which is approximately 105 kilometers (65 miles) northwest of Las Vegas, Nevada. CAU 140 consists of the following nine Corrective Action Sites (CASs):

- CAS 05-08-01, Detonation Pits

- CAS 05-08-02, Debris Pits

- CAS 05-17-01, Hazardous Waste Accumulation Site (Buried)

- CAS 05-19-01, Waste Disposal Site

- CAS 05-23-01, Gravel Gertie

- CAS 05-35-01, Burn Pit

- CAS 05-99-04, Burn Pit

- CAS 22-99-04, Radioactive Waste Dump

- CAS 23-17-01, Hazardous Waste Storage Area

CAU 140 closure activities were conducted from January 2005 to April 2005 in accordance with the FFACO and the Nevada Division of Environmental Protection-approved Corrective Action Plan for CAU 140 (U.S. Department of Energy, National Nuclear Security Administration Nevada Site Office, 2004b). All waste generated during the closure of CAU 140 was appropriately managed and disposed. CAU 140 closure activities are summarized in Table 1. 
Table 1. Summary of CAU 140 Closure Activities

\begin{tabular}{|c|c|c|c|c|}
\hline $\operatorname{CAS}^{\mathrm{a}}$ & CAS Name & $\begin{array}{c}\text { Approved Closure } \\
\text { Method }\end{array}$ & $\operatorname{coc}^{\mathrm{b}}$ & Closure Activities \\
\hline $05-08-01$ & Detonation Pits & Clean Closure & $\begin{array}{l}\text { Lead and } \\
\text { Th-234 }\end{array}$ & $\begin{array}{l}\text { - Metal edging removed } \\
\text { - Impacted soil removed } \\
\text { - Verification samples collected } \\
\text { - Excavation backfilled and } \\
\text { recontoured } \\
\text { - Surface debris removed as a BMP } \\
\end{array}$ \\
\hline 05-08-02 & Debris Pits & No Further Action & None & - Surface debris removed as a BMP \\
\hline $05-17-01$ & $\begin{array}{c}\text { Hazardous Waste } \\
\text { Accumulation Site } \\
\text { (Buried) }\end{array}$ & No Further Action & None & - Surface debris removed as a BMP \\
\hline 05-19-01 & Waste Disposal Site & No Further Action & None & - Surface debris removed as a BMP \\
\hline $05-23-01$ & Gravel Gertie & $\begin{array}{l}\text { Closure in Place with } \\
\text { Administrative } \\
\text { Controls }\end{array}$ & Uranium & $\begin{array}{l}\text { - Fencing installed } \\
\text { - Use restriction warning signs } \\
\text { posted } \\
\text { - Surface debris removed as a BMP } \\
\text { - Site use restriction implemented }\end{array}$ \\
\hline $05-35-01$ & Burn Pit & No Further Action & None & - None \\
\hline 05-99-04 & Burn Pit & No Further Action & None & - Surface debris removed as a BMP \\
\hline $22-99-04$ & $\begin{array}{l}\text { Radioactive Waste } \\
\text { Dump }\end{array}$ & No Further Action & None & - Sand bags removed as a BMP \\
\hline $23-17-01$ & $\begin{array}{l}\text { Hazardous Waste } \\
\text { Storage Area }\end{array}$ & $\begin{array}{l}\text { Closure in Place with } \\
\text { Administrative } \\
\text { Controls }\end{array}$ & $\mathrm{TPH}^{\mathrm{e}}$ & $\begin{array}{l}\text { - Monuments installed } \\
\text { - Use restriction warning signs } \\
\text { posted } \\
\text { - Site use restriction implemented }\end{array}$ \\
\hline
\end{tabular}

${ }^{\mathrm{a}} \mathrm{CAS}=$ Corrective Action Site

${ }^{\mathrm{b}} \mathrm{COC}=$ contaminant of concern

${ }^{\mathrm{c}} \mathrm{Th}-234=$ Thorium-234

${ }^{\mathrm{d}} \mathrm{BMP}=$ best management practice

${ }^{\mathrm{e}} \mathrm{TPH}=$ Total Petroleum Hydrocarbons 
This Closure Report (CR) documents the closure activities for Corrective Action Unit (CAU) 140, Waste Dumps, Burn Pits, and Storage Area, in accordance with the Federal Facility Agreement and Consent Order (FFACO) of 1996. CAU 140 consists of nine Corrective Action Sites (CASs) located in Areas 5, 22, and 23 of the Nevada Test Site (NTS) (Figure 1). The NTS is located approximately 105 kilometers (65 miles) northwest of Las Vegas, Nevada. Site closure activities were performed according to the Corrective Action Plan (CAP) for CAU 140 (U.S. Department of Energy, National Nuclear Security Administration Nevada Site Office [NNSA/NSO], 2004b) that was approved by the Nevada Division of Environmental Protection (NDEP). CAU 140 consists of the following CASs:

- CAS 05-08-01, Detonation Pits

- CAS 05-08-02, Debris Pits

- CAS 05-17-01, Hazardous Waste Accumulation Site (Buried)

- CAS 05-19-01, Waste Disposal Site

- CAS 05-23-01, Gravel Gertie

- CAS 05-35-01, Burn Pit

- CAS 05-99-04, Burn Pit

- CAS 22-99-04, Radioactive Waste Dump

- CAS 23-17-01, Hazardous Waste Storage Area

\subsection{PURPOSE}

CAU 140, Waste Dumps, Burn Pits, and Storage Area, consists of nine CASs located in Areas 5 , 22, and 23 of the NTS (Figure 1). The approved closure alternatives included No Further Action, Clean Closure, and Closure in Place with Administrative Controls. As a best management practice (BMP), surface debris was removed from several sites and disposed appropriately. The purpose of this CR is to document the CAU 140 closure activities and to provide data confirming that the NDEP-approved corrective actions (NNSA/NSO, 2004b) were met.

\subsection{SCOPE}

Previous site characterization work done in 2002 and 2003 found no contaminants of concern (COCs) above action levels at six of the CASs (CAS 05-08-02, CAS 05-17-01, CAS 05-19-01, CAS 05-35-01, CAS 05-99-04, and CAS 22-99-04). Thorium-234 (Th-234) and lead were found at concentrations greater than the action levels at CAS 05-08-01, and total petroleum hydrocarbon (TPH) contamination was found at concentrations greater than the action level at CAS 23-17-01. Process knowledge indicated that uranium contamination was present at CAS 05-23-01, and uranium was considered a COC for this site (NNSA/NSO, 2004a). 


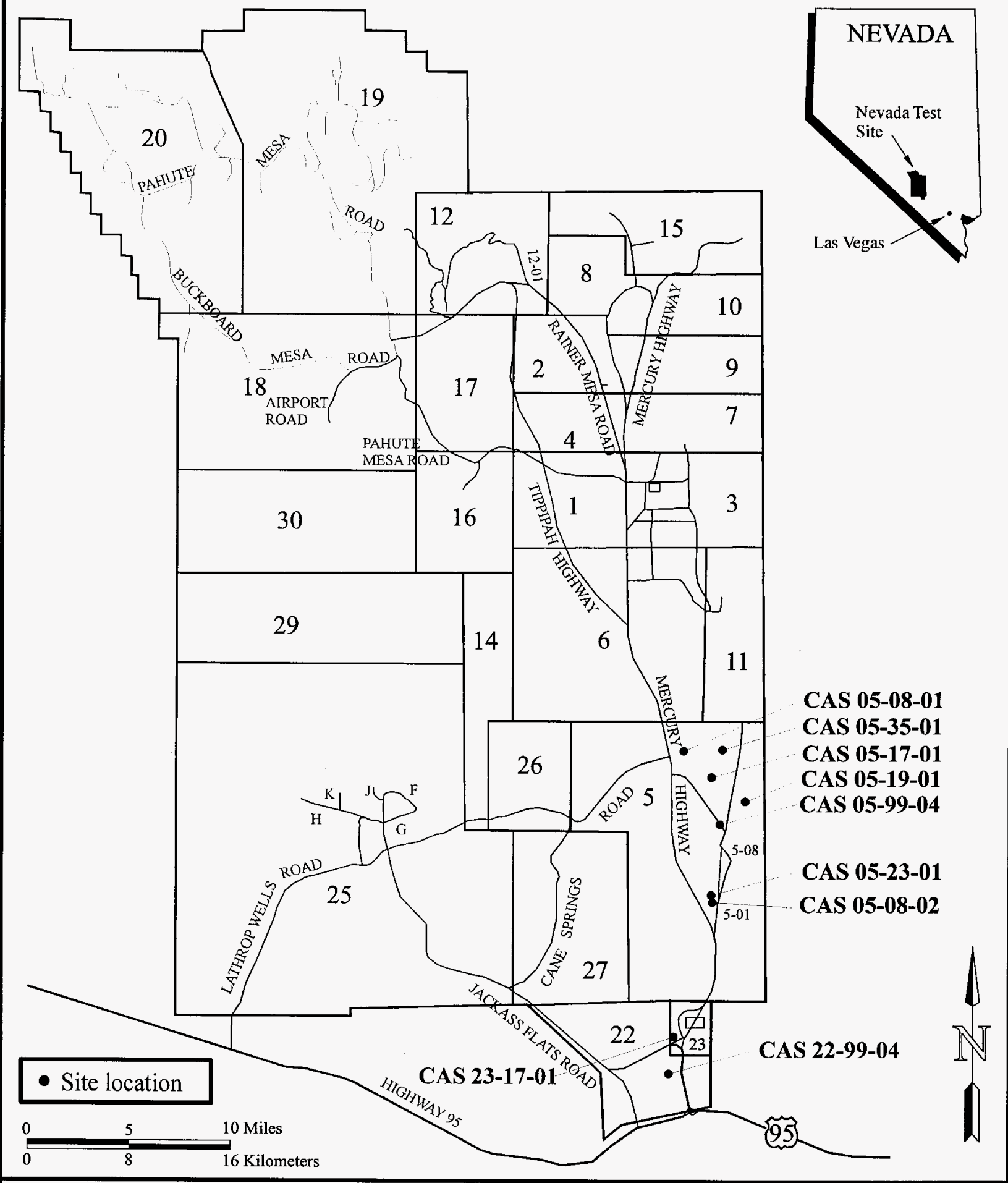

FIGURE 1

CAU 140 Site LOCATION MAP 
The closure strategy for CAU 140 was specified in the NDEP-approved CAP (NNSA/NSO, 2004b) as follows:

- CAS 05-08-01, Detonation Pits - The site was clean closed by removing metal edging, excavating impacted soil and disposing it as sanitary waste after a mixed waste profile was completed and the waste was found to be below the waste acceptance criteria for the sanitary landfill, collecting verification samples to verify that no COCs remained in the soil, backfilling the excavation, and removing surface debris as a BMP.

- CAS 05-08-02, Debris Pits - the site was closed by no further action; however, as a BMP, surface debris was removed.

- CAS 05-17-01, Hazardous Waste Accumulation Site (Buried) - the site was closed by no further action; however, as a BMP, surface debris was removed.

- CAS 05-19-01, Waste Disposal Site - the site was closed by no further action; however, as a BMP, surface debris was removed.

- CAS 05-23-01, Gravel Gertie - the site was closed in place with administrative controls. Fencing was installed, use restriction warning signs were posted, surface debris was removed as a BMP, and a use restriction was implemented.

- CAS 05-35-01, Burn Pit - the site was closed by no further action, and no field activities were conducted.

- CAS 05-99-04, Burn Pit - the site was closed by no further action; however, as a BMP, surface debris was removed.

- CAS 22-99-04, Radioactive Waste Dump - the site was closed by no further action; however, as a BMP, surface debris was removed.

- CAS 23-17-01, Hazardous Waste Storage Area - the site was closed in place with administrative controls. Monuments were installed, use restriction warning signs were posted, and a use restriction was implemented.

\subsection{Closure Report CONTENTS}

This CR includes the following sections:

- Section 1.0 - Introduction

- Section 2.0 - Closure Activities

- Section 3.0 - Waste Disposition

- Section 4.0 - Closure Verification Results

- Section 5.0 - Conclusions and Recommendations

- Section 6.0 - References

- Appendix A - Data Quality Objectives

- Appendix B - Closure Certification

- Appendix C - As-Built Documentation

- Appendix D - Sample Analytical Results

- Appendix E - Waste Disposition Documentation 
- Appendix F - Modifications to the Post-Closure Plan

- Appendix G - Use Restriction Documentation

- Appendix H - Site Closure Photographs

- Appendix I - Nevada Environmental Restoration Project Document Review Sheet

- Appendix J - National Environmental Policy Act Checklist

- Library Distribution List

The following Appendices listed in the approved FFACO CR outline do not apply to the CAU 140 closure:

- Appendix B - Closure Certification (not applicable [NA])

- Appendix C - As-Built Documentation (NA, no engineered structures were constructed)

- Appendix F - Modifications to the Post-Closure Plan (NA, no modifications to the plan were required)

This report was developed using information and guidance from the following documents:

- Corrective Action Decision Document (CADD) for CAU 140 (NNSA/NSO, 2004a)

- CAP for CAU 140 (NNSA/NSO, 2004b).

- Industrial Sites Quality Assurance Project Plan (QAPP) (U.S. Department of Energy, National Nuclear Security Administration Nevada Operations Office [NNSA/NV], 2002b).

\subsubsection{Data Quality Objectives}

The data quality objectives (DQOs) used for closure of CAU 140 were presented in Appendix A of the CAU 140 Corrective Action Investigation Plan (CAIP) (NNSA/NV, 2002a) and are included as Appendix A of this report.

Three general conceptual site models (CSMs), as presented in the CAIP (NNSA/NV, 2002a) and included as Appendix A of this report, were applied to the CASs in CAU 140. These CSMs assumed that any contamination was the result of both designed and accidental releases. The potential contamination would be attributable to direct release to the surface, burning activities, aerial dispersion testing or munitions detonation, erosion from the surface of solid materials, or leaching of contaminants from materials. The extent of the potential contamination was assumed to be minimal based on low precipitation and high evapotranspiration rates.

CAU 140 characterization results presented in the CADD (NNSA/NSO, 2004a), determined that actual site conditions were consistent with the CSMs developed during the DQO process. Closure activities also indicated that the CSMs were accurate with a few minor exceptions. Details of the DQO assessment are included in Section 4.1 of this report. 
This section details the specific closure activities completed during the closure of CAU 140, Waste Dumps, Burn Pits, and Storage Area. A copy of the analytical data reports for verification samples is included in Appendix D.

\subsection{DESCRIPTION OF CORRECTIVE ACTION ACTIVITIES}

\subsubsection{Preplanning and Site Preparation}

Closure activities for CAU 140 were completed using the NDEP-approved CAP (NNSA/NSO, 2004b). Prior to site closure activities, the following pre-field activities were completed:

- Preparation of National Environmental Policy Act documentation (checklist)

- Preparation of the Site-Specific Health and Safety Plan

- Preparation of a NNSA/NSO Real Estate/Operations Permit

- Preparation of required Bechtel Nevada (BN) work permits

- Preparation of BN work control packages

\subsubsection{Closure Activities}

Closure activities were conducted from January 2005 to April 2005 by the BN Environmental Restoration (ER) group. The following sections detail the activities completed at each CAS.

\subsubsection{CAS 05-08-01, Detonation Pits}

CAS 05-08-01 consisted of miscellaneous surface debris and two detonation pits, each defined by metal edging. Site characterization found one sample location impacted with lead and Th-234 above the preliminary action levels (PALs) at a depth of 0 to 0.3 meters $(\mathrm{m})$ ( 0 to 1 foot [ft]) below ground surface (bgs) (NNSA/NSO, 2004a).

The site was clean closed by removing surface debris, including scrap metal, miscellaneous wood debris, and the metal edging that defined the two detonation pits, and disposing it as sanitary waste at the Area $9 \mathrm{U} 10 \mathrm{c}$ Landfill. In addition, approximately 0.13 cubic meters $\left(\mathrm{m}^{3}\right)$ ( 0.17 cubic yards $\left.\left[\mathrm{yd}^{3}\right]\right)$ of soil that was assumed to be lead and radiologically impacted soil was excavated. The waste was managed as mixed waste; however, waste characterization analysis determined that the soil met sanitary landfill limits (see Section 3.3), and it was disposed at the Area 9 U10c Landfill. A portable X-Ray Fluorescence (XRF) unit was used to determine the extent of lead contamination in the soil, and radiological screening was used throughout the excavation.

One verification sample (Figure 2) was collected from the excavation and analyzed for total lead (U.S. Environmental Protection Agency [EPA], 1996) and gamma-emitting radionuclides (U.S. Department of Energy [DOE], 1997). The sample analytical results indicated that the remaining soil did not exceed the PALs for lead or radionuclides. The analytical data are summarized in Section 4.0, and the data report is included in Appendix D. The excavation was then backfilled with NTS native fill and contoured to the surrounding grade. 


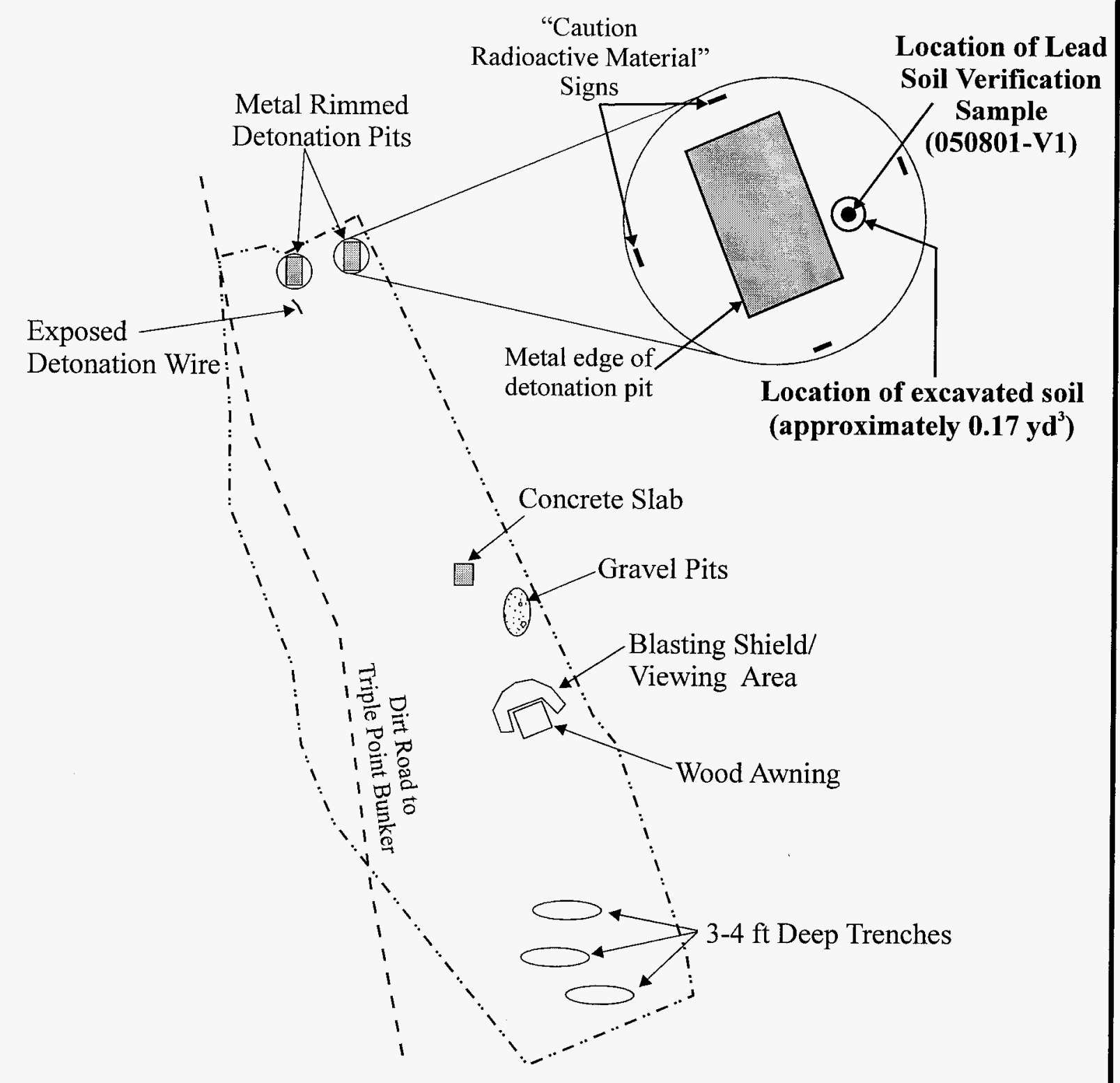

\section{LEGEND}

$-\cdots-\cdots-\cdots \cdot$ CAS Boundary

- Verification Sample Location

Not To Scale

Source: Modified from NNSA/NSO, 2004

FIGURE 2

CAS 05-08-01, DETONATION PITS, VERIFICATION SAMPLE LOCATION 


\subsubsection{CAS 05-08-02, Debris Pits}

CAS 05-08-02 consisted of miscellaneous surface debris and an evaporation basin. No COCs were identified during site characterization (NNSA/NSO, 2004a). As a BMP, the surface debris was removed and disposed as sanitary waste at the Area 9 U10c Landfill. One waste characterization sample was collected from a drum that contained approximately $0.019 \mathrm{~m}^{3}$ $\left(0.025 \mathrm{yd}^{3}\right)$ of soil. No COCs were identified above PALs in the soil in the drum, the soil was emptied from the drum, and the drum was disposed as sanitary waste at the Area 9 U10c Landfill. The waste characterization samples collected are listed in Section 3.3, and the analytical results are included in Appendix D.

\subsubsection{CAS 05-17-01, Hazardous Waste Accumulation Site (Buried)}

CAS 05-17-01 consisted of a small amount of surface debris. No COCs were identified during site characterization (NNSA/NSO, 2004a). As a BMP, the surface debris was removed and disposed as sanitary waste at the Area 9 U10c Landfill. Two glass bottles and two metal cans that were found onsite were screened for explosives, and three waste characterization samples were collected from the containers (Sample Numbers 051701-1, 051701-2, and 051701-3). The material in the bottles and cans was determined to be hydrocarbon waste. In the process of collecting these samples, the entire volume of material was removed to fulfill sample volume requirements. The empty containers were disposed as sanitary waste at the Area 9 U10c Landfill. One verification sample was collected from the soil beneath the bottles and cans (Sample Number 051701-4), and no COCs were identified above PALs for this sample. The waste characterization samples collected are listed in Section 3.3, and the verification sample results are summarized in Section 4.0. Analytical results are included Appendix D.

\subsubsection{CAS 05-19-01, Waste Disposal Site}

CAS 05-19-01 consisted of three areas, each defined by small amounts of surface debris. No COCs were identified during site characterization (NNSA/NSO, 2004a). As a BMP, the surface debris was removed and disposed as sanitary waste at the Area 9 U10c Landfill.

\subsubsection{CAS 05-23-01, Gravel Gertie}

CAS 05-23-01 consists of a bunker and a small amount of surface debris. No COCs were identified on the exterior of the structure during site characterization; however, the site was classified as a radiological control area. Process knowledge indicated that uranium contamination is present within the structure, and it is considered a COC (NNSA/NSO, 2004a). Due to the large volume of material present and the site's historical significance, the site was closed in place with administrative controls. As a BMP, scattered debris was removed from the site and disposed as sanitary waste at the Area 9 U10c Landfill. A three-strand wire fence was installed along the perimeter of the CAS, and warning signs were posted to prohibit intrusive activity according to the FFACO use restriction guidance (FFACO, 2003) (Figure 3). The LandUse Restriction Information form and a figure showing the boundary of the use-restricted area at CAS 05-23-01 are included in Appendix G. Annual site inspections will be required to ensure that the fence is in good repair, the signs are intact and legible, and the use restriction has been maintained. Details on the post-closure requirements for this CAS are included in Section 5.2. 


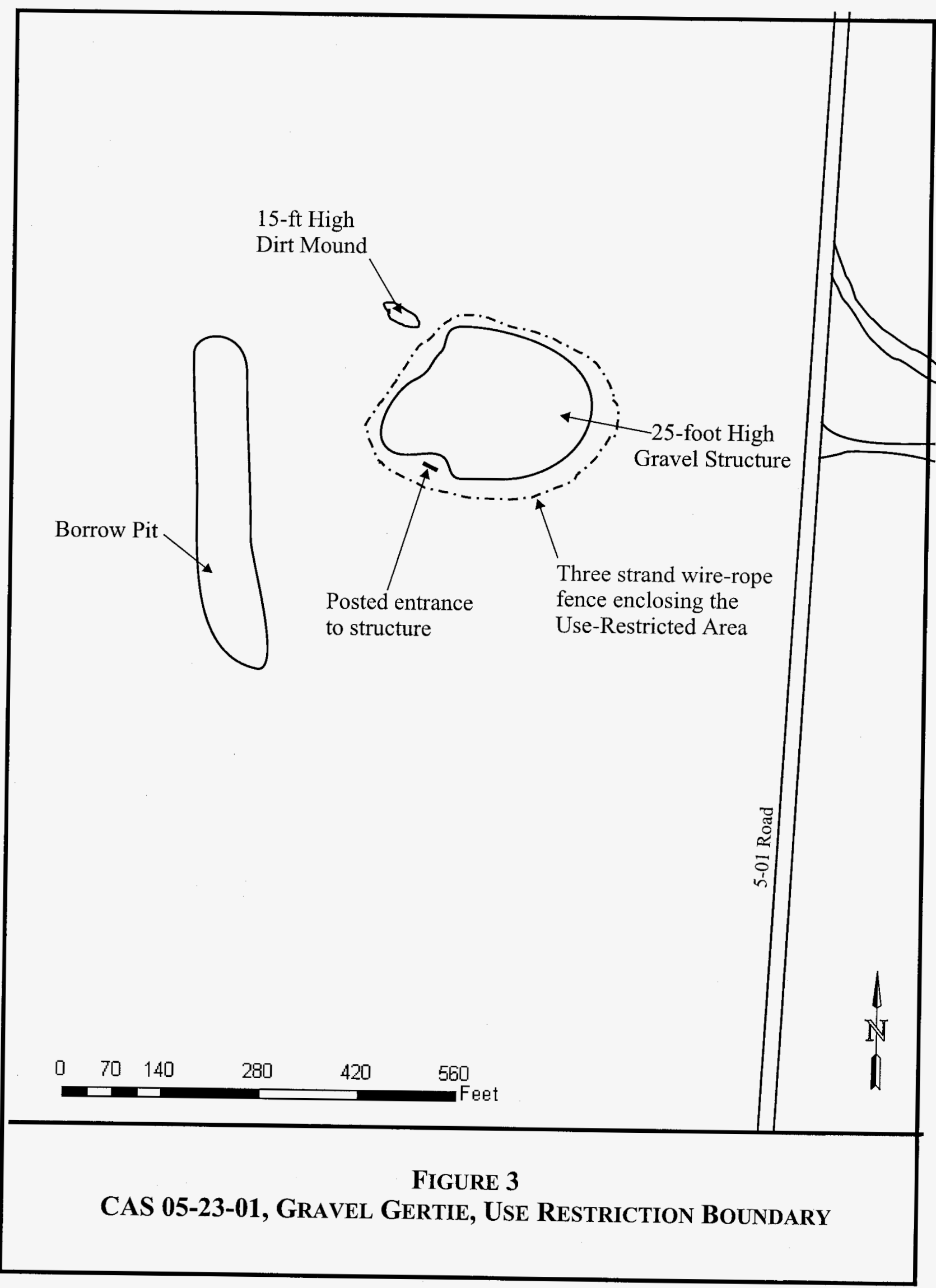




\subsubsection{CAS 05-35-01, Burn Pit}

CAS 05-35-01 consisted of two surface burn stains. No COCs were identified during site characterization (NNSA/NSO, 2004a). The site was closed by taking no further action, and no work was performed at this site.

\subsubsection{CAS 05-99-04, Burn Pit}

CAS 05-99-04 consisted of three surface burn areas containing surface debris. No COCs were identified during site characterization (NNSA/NSO, 2004a). As a BMP, the surface debris was removed and disposed as sanitary waste at the Area 9 U10c Landfill.

\subsubsection{CAS 22-99-04, Radioactive Waste Dump}

CAS 22-99-04 consisted of a bermed area containing deteriorating sand bags. No COCs were identified during site characterization (NNSA/NSO, 2004a). As a BMP, the sand bags were removed and disposed as sanitary waste at the Area 9 U10c Landfill.

\subsubsection{CAS 23-17-01, Hazardous Waste Storage Area}

CAS 23-17-01 consisted of a former hazardous waste storage area and landfill containing buried debris. No surface debris was present. In addition, an area outside of the landfill footprint was found to be impacted with TPH at concentrations above the Nevada State Action Level of 100 milligrams per kilogram (Nevada Administrative Code [NAC], 2002) at 2.7 to $3 \mathrm{~m}$ (9 to $10 \mathrm{ft}$ ) bgs (NNSA/NSO, 2004a).

Both the former landfill and the TPH-impacted area were closed in place with administrative controls. Monuments were installed to delineate the boundary of the landfill. Use restriction warning signs were posted on the monuments to prohibit intrusive activity according to the FFACO Use Restriction Posting Guidance (FFACO, 2003). In addition, use restriction warning signs were hung on T-posts to delineate the TPH-impacted area (Figure 4). The Land-Use Restriction Information form and a figure showing the locations of the surveyed points delineating the use-restricted areas at CAS 23-17-01 are included in Appendix G. Annual site inspections will be required to ensure that the signs are intact and legible, and that the use restriction has been maintained. Details on the post-closure requirements for this CAS are included in Section 5.2.

\subsection{Deviations From CoRRective ACtion Plan as APPROVED}

The NDEP-approved CAP (NNSA/NSO, 2004b) was modified during field activities to adjust to unexpected conditions and simplify activities. The following deviation occurred from the approved scope of work as presented in the NDEP-approved CAP (NNSA/NSO, 2004b).

\subsubsection{CAS 05-08-01, Detonation Pits}

It was originally stated in the CAP that a minimum of five soil verification samples would be collected from the excavation at this site. This sampling plan was based on the original estimate in the CADD that assumed $2.2 \mathrm{~m}^{3}\left(2.9 \mathrm{yd}^{3}\right)$ of impacted soil needed to be excavated 


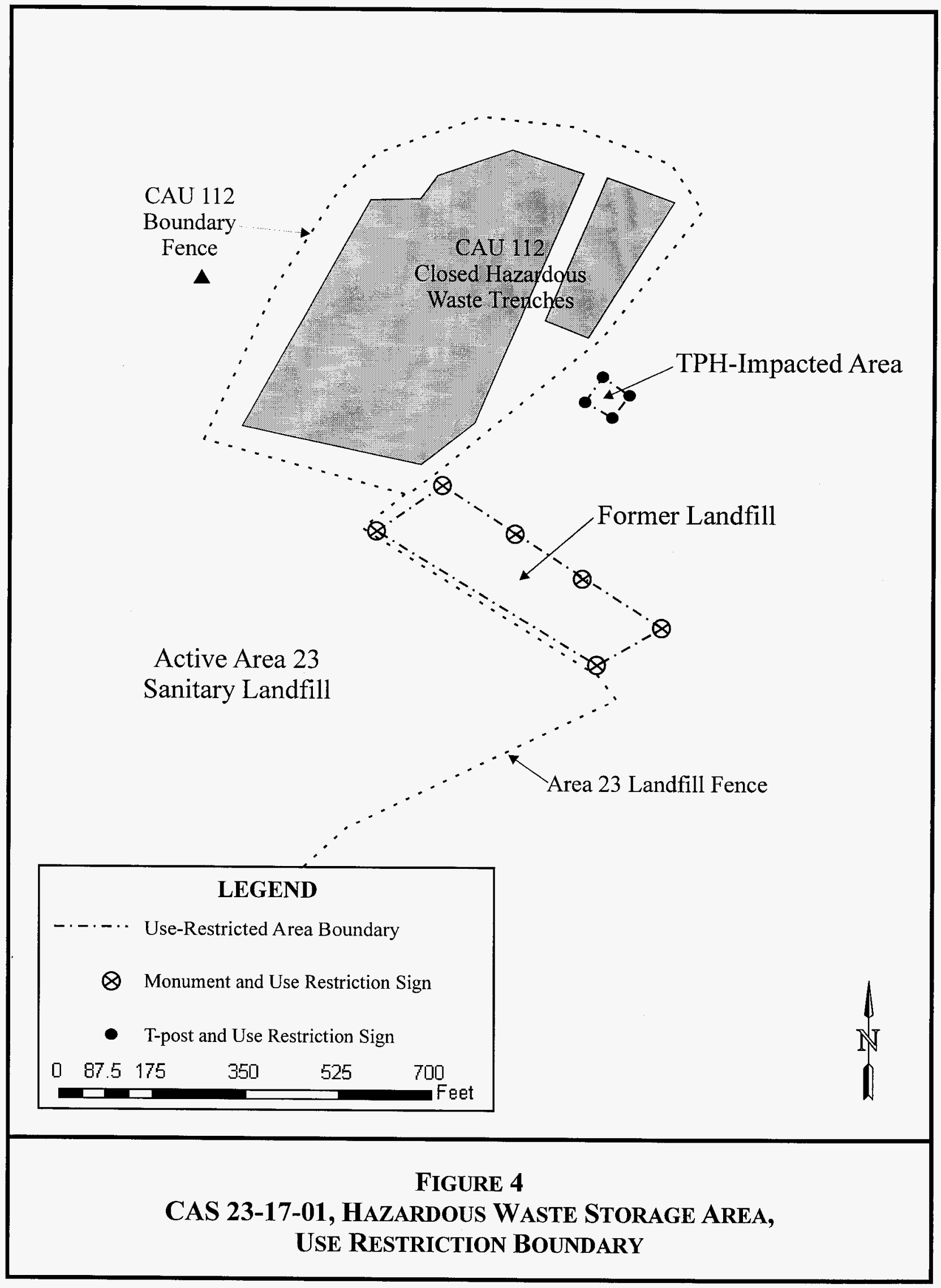


(NNSA/NSO, 2004a). During field activities, a portable XRF was used to screen for lead, and radiological screening was performed throughout the excavation. This allowed for a more thorough delineation of the extent of impacted soil, and the amount of waste was minimized. The field screening results indicated that only $0.13 \mathrm{~m}^{3}\left(0.17 \mathrm{yd}^{3}\right)$ of soil was impacted instead of the originally estimated $2.2 \mathrm{~m}^{3}\left(2.9 \mathrm{yd}^{3}\right)$. The excavation was approximately $0.3 \mathrm{~m}(1 \mathrm{ft})$ wide and $0.3 \mathrm{~m}(1 \mathrm{ft})$ deep and only required one verification sample to verify that concentrations remaining onsite were below PALs.

\subsection{CORRECTIVE ACTION SCHEdule AS COMPLETED}

CAU 140 closure activities began in January 2005 and were completed in April 2005. Details of the field activities schedule are provided in Table 2.

Table 2. CAU 140 Field Activities Schedule

\begin{tabular}{|c|c|c|c|c|}
\hline $\mathrm{CAS}^{\mathrm{a}}$ & CAS Description & CAS Location & Mobilization & Demobilization \\
\hline $05-08-01$ & Detonation Pits & Area 5 & 09 February 2005 & 07 April 2005 \\
\hline $05-08-02$ & Debris Pits & Gravel Gertie & 26 January 2005 & 09 February 2005 \\
\hline $05-17-01$ & $\begin{array}{l}\text { Hazardous Waste } \\
\text { Accumulation Site } \\
\text { (Buried) }\end{array}$ & Triple Point Bunker & 20 April 2005 & 21 April 2005 \\
\hline 05-19-01 & $\begin{array}{l}\text { Waste Disposal } \\
\text { Site }\end{array}$ & N Frenchman Lake & 09 February 2005 & 15 February 2005 \\
\hline $05-23-01$ & Gravel Gertie & Gravel Gertie & 08 February 2005 & 07 April 2005 \\
\hline $05-35-01$ & Burn Pit & Area 5 RWMS & $\mathrm{N} / \mathrm{A}$ & $\mathrm{N} / \mathrm{A}$ \\
\hline $05-99-04$ & Burn Pit & Spill Test Facility & 11 February 2005 & 11 February 2005 \\
\hline $22-99-04$ & $\begin{array}{l}\text { Radioactive Waste } \\
\text { Dump }\end{array}$ & Camp Desert Rock & 10 February 2005 & 10 February 2005 \\
\hline $23-17-01$ & $\begin{array}{l}\text { Hazardous Waste } \\
\text { Storage Area }\end{array}$ & Area 23 & 23 March 2005 & 07 April 2005 \\
\hline
\end{tabular}

${ }^{\mathrm{a}} \mathrm{CAS}=$ Corrective Action Site

\subsection{Site Plan/Survey Plan}

CAS 05-23-01, Gravel Gertie, and CAS 23-17-01, Hazardous Waste Storage Area, were closed in place with administrative controls (i.e., Use Restrictions). Figures showing the locations of the surveyed points delineating the use-restricted areas at these CASs are provided in Appendix G. 
Closure Report - CAU 140

Section: Closure Activities

Revision: 0

Date: August 2005

THIS PAGE INTENTIONALLY LEFT BLANK 
This section describes the waste generated at CAU 140 during closure activities and their final disposition. All waste was managed in accordance with applicable state and federal regulations, DOE orders, and $\mathrm{BN}$ procedures.

\subsection{WASTE Minimization}

Industry standard waste minimization practices were used during all field activities. These practices included:

- Using a portable XRF unit to field screen for lead contamination. This allowed for a better delineation of the extent of lead-impacted soil which was determined to be surface soil only ( 0 to $0.3 \mathrm{~m}[0$ to $1 \mathrm{ft}]$ bgs).

- Using laboratory analysis to correctly characterize and classify waste streams.

\subsection{CONTAiner Management}

All waste was managed according to applicable state and federal regulations, DOE orders, the CAU 140 CAP (NNSA/NSO, 2004b), BN Waste Management procedures, and company directives.

End-dumps were used to transport sanitary waste to the Area 9 U10c Landfill. Waste disposition documentation is presented in Appendix E.

One standard 208-L (55-gal) U.S. Department of Transportation (DOT) rated steel drum was used for sanitary waste. The drum was inspected prior to use to verify that it was in good condition (i.e., no leaks, rust, or dents), lined or made of a material that would not react with the waste, and met DOT requirements. The drum was inspected and approved by BN Waste Generator Services (WGS) personnel prior to use and was kept closed while stored unless waste was being added or removed. The drum was also handled in such a manner that the integrity of the container was not compromised. Appropriate labels were affixed and relevant information was marked on the container with an indelible marker. The information was legible and clearly visible.

\subsection{WaSte Characterization}

Waste streams were characterized according to the CAU 140 CAP (NNSA/NSO, 2004b), BN Solid Waste Operations, and BN WGS procedures. Laboratory samples were collected, sealed with a custody seal, cooled to four degrees Celsius, and logged onto a chain of custody. Waste characterization samples collected are listed in Table 3.

\subsection{WASTE STREAMS AND Disposal}

Waste streams generated during closure activities at CAU 140 included non-impacted sanitary debris. Waste disposition documentation is presented in Appendix E. 


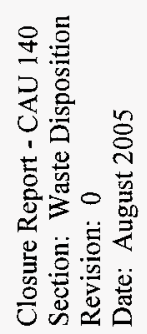

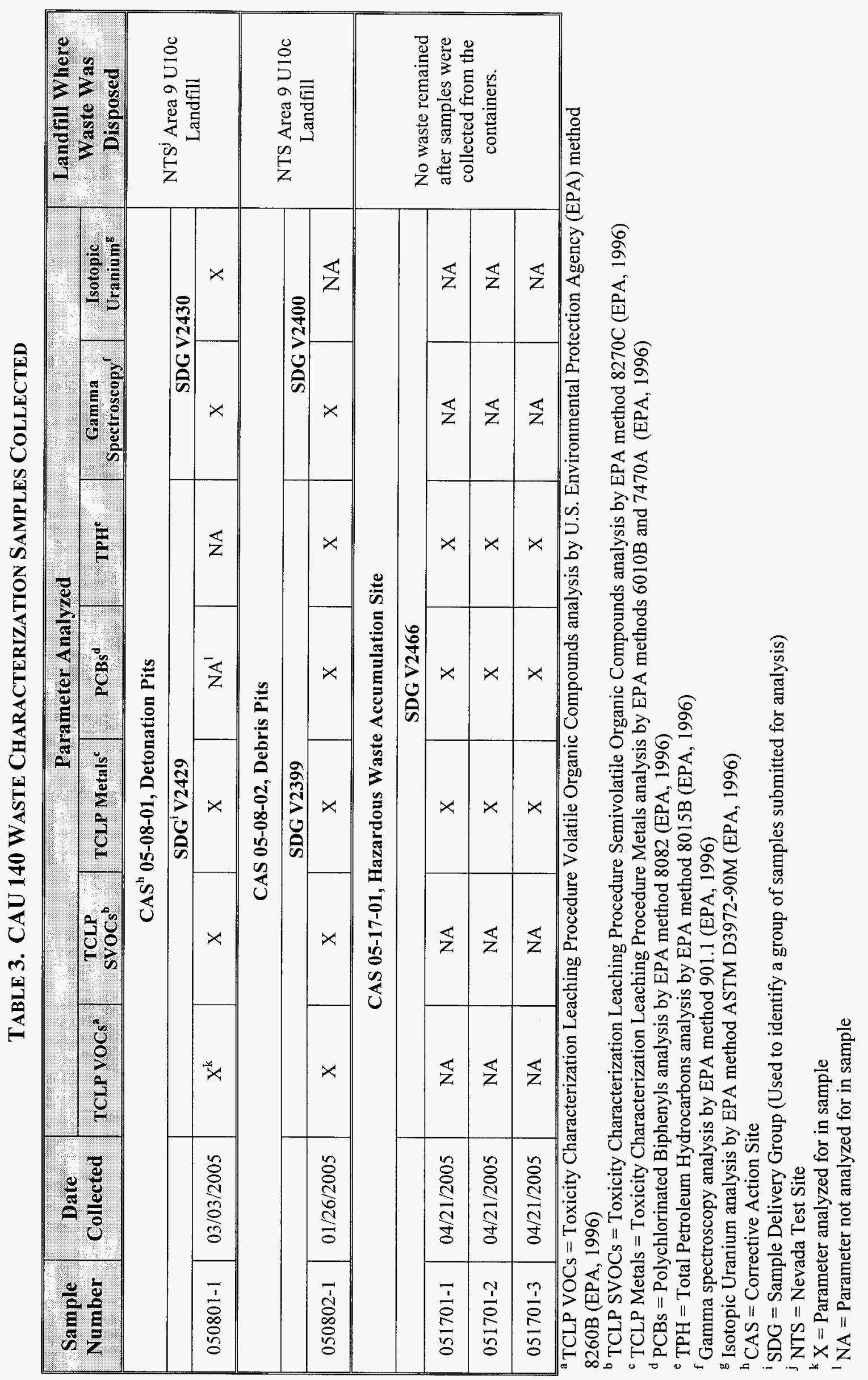




\subsubsection{Sanitary Waste}

Approximately $38 \mathrm{~m}^{3}\left(50 \mathrm{yd}^{3}\right)$ of sanitary waste was transported and disposed at the NTS Area 9 U10c Landfill. This waste included scrap metal, wood, plastic, steel pipe segments, and sand bags. Waste disposition documentation is presented in Appendix E. 
Closure Report - CAU 140

Section: Waste Disposition

Revision: 0

Date: August 2005

THIS PAGE INTENTIONALLY LEFT BLANK 
To verify that CAU 140 closure activities met clean-up criteria, one soil verification sample was collected and analyzed at CAS 05-08-01, Detonation Pits. Figure 2 shows the verification sample location. Clean closure was accomplished at CAS 05-08-01 by removing and disposing surface debris and approximately $0.13 \mathrm{~m}^{3}\left(0.17 \mathrm{yd}^{3}\right)$ of lead and radiologically impacted soil. The verification sample was analyzed for lead and radiological isotopes. The results showed no COCs above PALs. Sample results are shown in Table 4, and the laboratory data report is included in Appendix D.

Table 4. CAU 140 Verification SAMple Results

\begin{tabular}{|c|c|c|c|c|c|}
\hline $\begin{array}{l}\text { SAMPLE } \\
\text { NUMBER }\end{array}$ & $\begin{array}{c}\text { Date } \\
\text { Collected }\end{array}$ & $\begin{array}{l}\text { DEPTH } \\
\text { (feet) }\end{array}$ & $\begin{array}{l}\text { TOTAL } \\
\text { LEAD } \\
\left(\mathbf{m g} / \mathbf{k g}^{\mathbf{b}}\right)\end{array}$ & $\begin{array}{c}\text { GAMMA } \\
\text { SPECTROS } \\
\text { COPYc }^{\text {copidi }} \\
\left(\mathrm{pCi} / \mathrm{g}^{\mathrm{d}}\right) \\
\end{array}$ & $\begin{array}{c}\mathbf{T P H}^{\mathbf{e}} \\
\text { (mg/kg) }\end{array}$ \\
\hline \multicolumn{3}{|c|}{ CAS 05-08-01, Detonation Pits } & SDG ${ }^{f} V 2423$ & SDG V2424 & \\
\hline $050801 \mathrm{~V} 1$ & $03 / 03 / 2005$ & 0.5 & 21.9 & $<\mathrm{PALs}^{\mathrm{g}}$ & $\mathrm{NA}^{\mathrm{h}}$ \\
\hline \multicolumn{3}{|c|}{ CAS 05-17-01, Hazardous Waste Accumulation Site (Buried) } & & & SDG V2466 \\
\hline $051701-4$ & $04 / 25 / 2005$ & surface & NA & NA & $<\mathrm{PAL}$ \\
\hline
\end{tabular}

${ }^{a}$ Lead analysis by U.S. Environmental Protection Agency (EPA) method 6010B (EPA, 1996).

${ }^{\mathrm{b}} \mathrm{mg} / \mathrm{kg}=$ milligrams per kilogram

${ }^{\mathrm{c}}$ Gamma Spectroscopy analysis by U.S. Environmental Protection Agency (EPA) method 901.1 (EPA, 1996)

${ }^{\mathrm{d}} \mathrm{pCi} / \mathrm{g}=$ picocuries per gram

${ }^{\mathrm{e}} \mathrm{TPH}=$ Total Petroleum Hydrocarbons

${ }^{\mathrm{f}} \mathrm{SDG}=$ Sample Delivery Group (used to identify a group of samples submitted for analysis)

${ }^{\mathrm{g}} \mathrm{PAL}=$ Preliminary Action Level

${ }^{\mathrm{h}} \mathrm{NA}=$ Parameter not analyzed for in sample

\subsection{Data Quality AsSESSMENT}

Accurate and defensible analytical data were collected to verify that waste and verification samples were properly characterized, managed, and disposed during CAU 140 closure activities. The following sections describe the quality assurance (QA) / quality control (QC) procedures, data validation process, and a reconciliation of the CSM with actual findings during CAU 140 closure activities.

\subsubsection{Quality Assurance/Quality Control Procedures}

Below is a summary of the QA/QC procedures for CAU 140. More detail can be found in the CAU 140 CAP (NNSA/NSO, 2004b). Verification and waste characterization samples were collected with disposable polyethylene scoops and placed in appropriately labeled sample containers secured with custody seals. All samples were labeled with a unique sample number, placed on ice in coolers, and transported under a chain-of-custody. Standard QA/QC samples were collected (i.e., collecting one field duplicate per 20 samples submitted blind to the analytical laboratory for analysis). Samples were analyzed by BN contract laboratories. 
Analytical results were validated at the laboratory using stringent QA/QC procedures. This included matrix spike/matrix spike duplicate, spiked surrogate percent recovery, verification, validation of analytical results, and affirmation of Data Quality Indicator requirements related to laboratory analysis. Detailed information regarding the QA program can be found in the Industrial Sites QAPP (NNSA/NV, 2002b).

Waste characterization samples were collected at CAS 05-08-01, Detonation Pits; CAS 05-08-02, Debris Pits; and CAS 05-17-01, Hazardous Waste Accumulation Site (Buried), to properly classify the waste for disposal. Waste characterization samples collected are listed in Table 3.

One verification sample was collected at CAS 05-08-01, Detonation Pits (Figure 2). The site was considered to be clean closed when the laboratory results for the verification samples showed that COCs were below action levels. Verification sample results are listed in Table 4.

\subsubsection{Data Validation}

Data validation was performed in accordance with the Industrial Sites QAPP (NNSA/NV, 2002b) which is based on the EPA functional guidelines for data quality (EPA, 1994 and 1999). Data were reviewed to ensure that samples were appropriately processed and analyzed, and that the results of the samples are valid. All sample data were internally validated by qualified BN personnel using Tier I and the majority of elements that comprise Tier II. No anomalies were discovered in the data that would discredit any of the waste characterization or verification samples from CAU 140 . While only summary laboratory QC data for verification samples are presented in Appendix D of this document, the complete data set and validation reports for verification samples and waste characterization samples are available upon request. This data set is maintained in the BN ER project files in Mercury, NV.

\subsubsection{Conceptual Site Models}

Three CSMs were developed for CAU 140 in the CAIP (NNSA/NV, 2002a).

The first CSM, Surface Material, applied to all of the CASs in CAU 140. This CSM assumed that surface and near-surface soil was potentially contaminated due to release of contaminants through burning activities, aerial dispersion testing of munitions detonation, erosion of various contaminants off the surface of solid materials, and leaching of contaminants from materials. The degree of contaminant migration was assumed to be minimal based on low precipitation and high evapotranspiration rates. This CSM was confirmed by soil sample results presented in the CADD (NNSA/NSO, 2004a) and verified during closure activities. Contamination was found to a depth of $0.3 \mathrm{~m}(1 \mathrm{ft}) \mathrm{bgs}$, and samples collected at greater depths were below action levels (NNSA/NSO, 2004a).

The second CSM, Buried Debris, applied to CAS 05-08-01, Detonation Pits; CAS 05-17-01, Hazardous Waste Accumulation Site (Buried); CAS 05-19-01, Waste Disposal Site; and CAS 23-17-01, Hazardous Waste Storage Area. The Buried Debris CSM was in addition to the Surface Material CSM for these CASs. It assumed that liquid waste or leaching of contaminants off the surface of buried materials could have contributed contamination to subsurface soil. This CSM varied slightly from what was found during characterization and closure activities. 
Samples collected at depths greater than $0.3 \mathrm{~m}(1 \mathrm{ft})$ bgs were below the action levels and confirmed that COCs were not present at depths greater than $0.3 \mathrm{~m}(1 \mathrm{ft})$ bgs (NNSA/NSO, 2004a). Therefore, only the first CSM, Surface Material, applied to these CASs.

The third CSM, Internal Structure, applied to CAS 05-23-01, Gravel Gertie. It assumed that the floor, walls, and roof in the detonation and adjoining corridors/rooms of the Gravel Gertie, along with the gravel in the roof of the Gravel Gertie, are the most likely places to find contamination. Due to the physical constraints of the structure, it was not practical to collect samples from inside the Gravel Gertie. However, based on historical documentation, the internal structure is considered to be contaminated with uranium, and no variations to this CSM were identified during characterization or closure activities.

\subsection{USE RESTRICTION}

Use restrictions have been implemented for CAS 05-23-01, Gravel Gertie, and CAS 23-17-01, Hazardous Waste Storage Area. The following CASs have been closed by clean closure or no further action, and use of the areas associated with these sites is unrestricted:

- CAS 05-08-01, Detonation Pits

- CAS 05-08-02, Debris Pits

- CAS 05-17-01, Hazardous Waste Accumulation Site (Buried)

- CAS 05-19-01, Waste Disposal Site

- CAS 05-35-01, Burn Pit

- CAS 05-99-04, Burn Pit

- CAS 22-99-04, Radioactive Waste Dump

\subsubsection{CAS 05-23-01, Gravel Gertie}

No COCs were identified on the exterior of the structure during site characterization; however, process knowledge indicates that uranium contamination is present within the internal structure (NNSA/NSO, 2004a). A three-strand wire fence was installed along the perimeter of the CAS. Use restriction warning signs (Figure 5) were erected in the area according to the FFACO use restriction guidelines (FFACO, 2003) and as specified in the CAP (NNSA/NSO, 2004b). The CAU Land-Use Restriction Information form and a figure showing the locations of the surveyed points delineating the use-restricted areas at CAS 05-23-01 are included in Appendix G.

\subsubsection{CAS 23-17-01, Hazardous Waste Storage Area}

Monuments were installed to delineate the boundary of the landfill. Use restriction warning signs (Figure 6) were posted on the monuments to warn against intrusive activity according to the FFACO use restriction guidelines (FFACO, 2003). In addition, use restriction warning signs (Figure 7) were installed on T-posts to delineate the TPH-impacted area. The CAU Land-Use Restriction Information form and a figure showing the locations of the surveyed points delineating the use-restricted area at CAS 23-17-01 are included in Appendix G. 


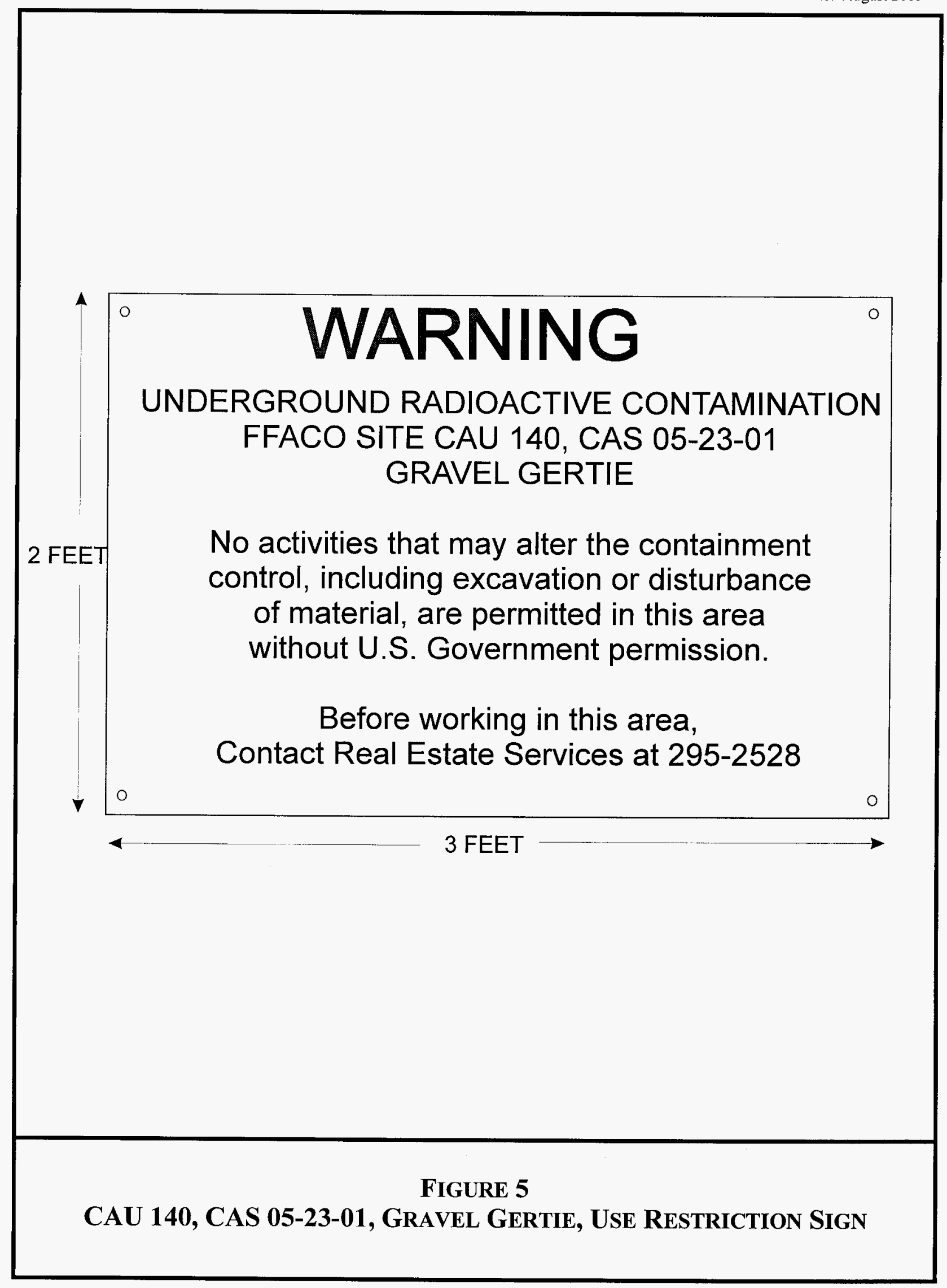




\section{WARNING}

BURIED LANDFILL CELL

FFACO SITE CAU 140, CAS 23-17-01 HAZARDOUS WASTE STORAGE AREA

No activities that may alter the 1 FOOT containment control, including excavation or disturbance of material, are permitted in this area without U.S. Government permission.

Before working in this area, Contact Real Estate Services at 295-2528

4 1 FOOT

FIGURE 6

CAU 140, CAS 23-17-01, HaZardous Waste Storage AREA, LANDFILL, USE RESTRICTION SIGN 


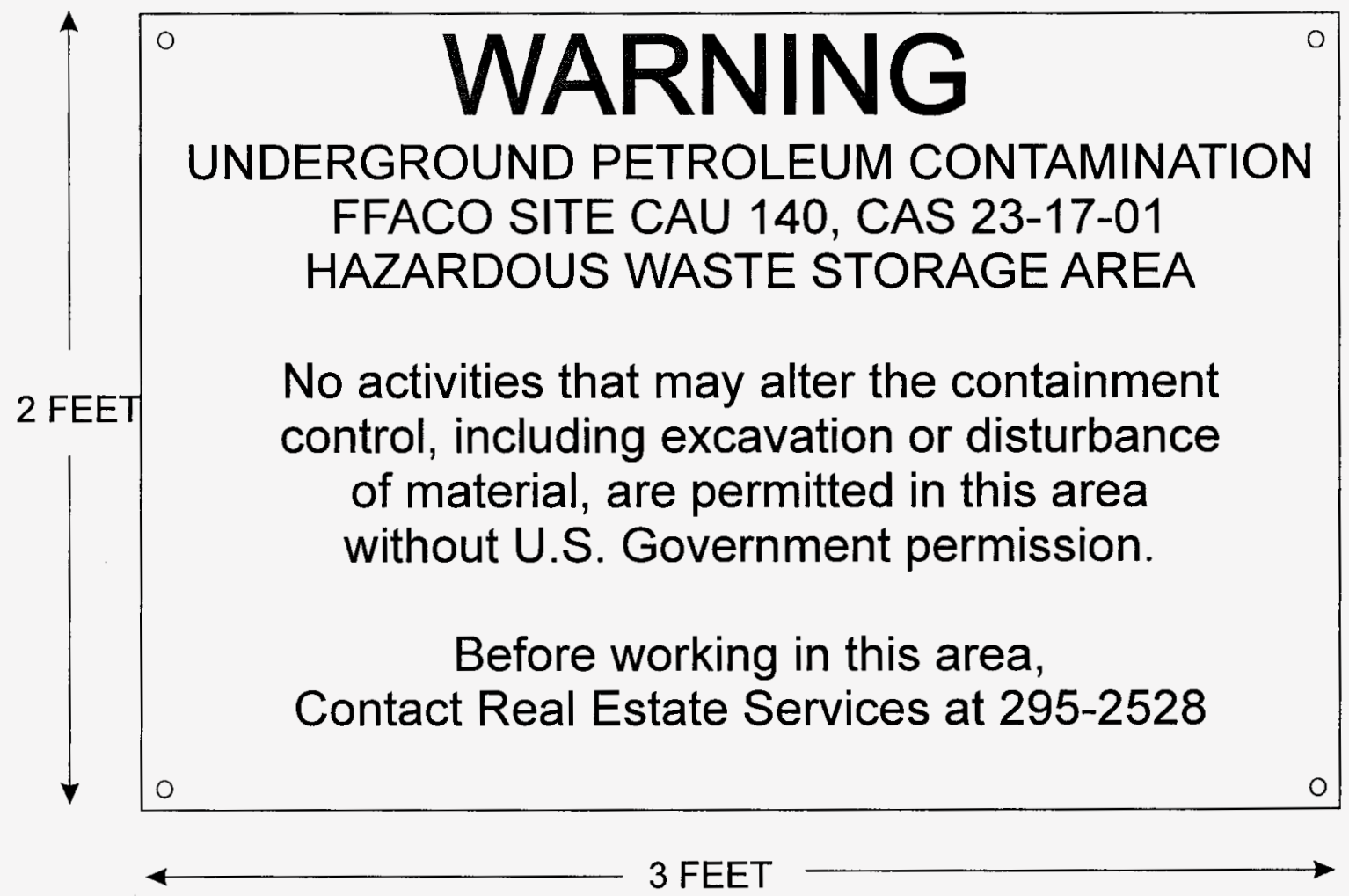

FIGURE 7

CAU 140, CAS 23-17-01, Hazardous Waste Storage AREA, TPH-IMPACTED AREA, USE RESTRICTION SIGN 


\subsection{CONCLUSIONS AND RECOMMENDATIONS}

\subsection{CONCLUSIONS}

The following site closure activities were performed at CAU 140 and are documented in this CR:

CAS 05-08-01, Detonation Pits - The site was clean closed by removing surface debris and lead and radiologically impacted soil. One verification sample was collected from the bottom of the excavation, and the analytical results were below the PALs. The excavated soil was determined to be sanitary waste on the basis of waste characterization sample results. The surface debris and excavated soil was disposed as sanitary waste at the Area 9 U10c Landfill. The excavation was backfilled with NTS native fill material.

CAS 05-08-02, Debris Pits - No further action was performed at this CAS. As a BMP, surface debris was removed. Waste characterization sample results from soil in a drum that was found onsite showed no COCs above the PALs, and the drum was disposed as sanitary waste at the Area 9 U10c Landfill with the other surface debris removed from this site.

CAS 05-17-01, Hazardous Waste Accumulation Site (Buried) - No further action was performed at this CAS. As a BMP, surface debris was removed. Waste characterization sample results from glass bottles and metal cans that were found onsite indicated that hydrocarbons were present above the PALs; however, no material remained in the containers after the samples were collected, and the empty containers were disposed as sanitary waste at the Area 9 U10c Landfill with the other surface debris removed from this site. A verification sample was collected from the bottles/cans footprint and analyzed for TPH, and the results were below the PALs.

CAS 05-19-01, Waste Disposal Site - No further action was performed at this CAS. As a BMP, surface debris was removed and disposed as sanitary waste at the Area 9 U10c Landfill.

CAS 05-23-01, Gravel Gertie - The site was closed in place with administrative controls. As a BMP, surface debris was removed and disposed as sanitary waste at the Area 9 U10c Landfill. A three-strand wire fence was installed, and use restriction warning signs were posted. Annual site inspections will be conducted at this CAS.

CAS 05-35-01, Burn Pit - No further action was performed at this CAS.

CAS 05-99-04, Burn Pit. No further action was performed at this CAS. As a BMP, surface debris was removed and disposed at sanitary waste at the Area 9 U10c Landfill.

CAS 22-99-04 - No further action was performed at this CAS. As a BMP, surface debris was removed and disposed as sanitary waste at the Area 9 U10c Landfill.

CAS 23-17-01, Hazardous Waste Storage Area - The site was closed in place with administrative controls. Monuments were installed along the boundary of the landfill, and use restriction signs warning were posted on the monuments. Use restriction warning signs were posted on T-posts along the boundary of a small TPH-impacted area. Annual site inspections will be conducted at this CAS. 


\subsection{Post-Closure REQUIREMENTS}

Details of the CAU 140 post-closure monitoring plan are provided below:

\subsubsection{Inspections}

Inspections will be performed on an annual basis at CAS 05-23-01, Gravel Gertie, and CAS 23-17-01, Hazardous Waste Storage Area.

\subsubsection{CAS 05-23-01, Gravel Gertie}

Inspections will consist of visual observations to verify that the fence is in good repair, the proper signs are in place and readable, and the use restriction is maintained. The results of the inspection will be documented in a single annual letter report. The letter report will include a discussion of observations and inspections, copies of the site inspection checklists and any maintenance records. A copy of the annual letter report will be submitted to the NDEP.

CAS 05-23-01 is currently posted as an Underground Radioactive Material area. As part of the NTS Radiological Control Demarcation and Maintenance program, sites posted as Underground Radioactive Material areas are inspected and resurveyed once every four years to verify that the site postings are correct. Therefore, CAS 05-23-01 use restriction signs will be inspected and the area resurveyed once every four years by Radiological Control Demarcation and Maintenance personnel. Demarcation and Maintenance personnel will perform a radiological survey of the CAS perimeter along the fence, perform any needed maintenance on the existing radiological postings, and, if indicated by survey results, update the radiological site postings. Results of all radiological surveys will be maintained in the project files.

If any maintenance and repair requirements are identified during the annual inspection of CAS 05-23-01, funding will be requested and the repairs scheduled. Any repair or maintenance performed at this site shall be documented in writing at the time of the repair and included in the annual letter report.

\subsubsection{CAS 23-17-01, Hazardous Waste Storage Area}

Inspections will consist of visual observations to verify that the proper signs are in place and readable and the use restriction is maintained. The results of the inspection will be documented in a single annual letter report. The letter report will include a discussion of observations and inspections, copies of the site inspection checklists and any maintenance records. A copy of the annual letter report will be submitted to the NDEP.

If any maintenance and repair requirements are identified during the annual inspection of CAS 23-17-01, funding will be requested and the repairs scheduled. Any repair or maintenance performed at this site shall be documented in writing at the time of the repair and included in the annual letter report. 


\subsection{RECOMMENDATIONS}

Since closure activities for CAU 140 have been completed following the NDEP-approved CAP (NNSA/NSO, 2004b) as documented in this report, NNSA/NSO requests the following:

1. A Notice of Completion be provided by the NDEP to the NNSA/NSO for the closure of CAU 140.

2. The transfer of CAU 140 from Appendix III to Appendix IV, Closed Corrective Action Units, of the FFACO (FFACO, 1996). 
Closure Report - CAU 140

Section: Conclusions \& Recom

Revision: 0

Date: August 2005

\section{THIS PAGE INTENTIONALLY LEFT BLANK}




\subsection{REFERENCES}

DOE, see U.S. Department of Energy.

EPA, see U.S. Environmental Protection Agency.

Federal Facility Agreement and Consent Order. 1996 (as amended). Agreed to by the State of Nevada, the U.S. Department of Energy, and the U.S. Department of Defense.

Federal Facility Agreement and Consent Order. 2003. Use Restriction Posting Guidance.

FFACO, see Federal Facility Agreement and Consent Order.

NAC, see Nevada Administrative Code.

Nevada Administrative Code. 2002. 445A.2272, Contamination of Soil: Establishment of Action Levels. Carson City, NV.

NNSA/NSO, see U.S. Department of Energy, National Nuclear Security Administration Nevada Site Office

NNSA/NV, see U.S. Department of Energy, National Nuclear Security Administration Nevada Operations Office

U.S. Department of Energy. 1997. Environmental Measurements Laboratory Procedure Manual, HASL-300. Washington, D.C.

U.S. Department of Energy, National Nuclear Security Administration Nevada Operations Office. 2002a. Corrective Action Investigation Plan for Corrective Action Unit 140: Waste Dumps, Burn Pits, and Storage Area, Nevada Test Site, Nevada. DOE/NV--826, Las Vegas, NV.

U.S. Department of Energy, National Nuclear Security Administration Nevada Operations Office. 2002b. Nevada Environmental Restoration Project Industrial Sites Quality Assurance Project Plan, Nevada Test Site, Nevada. DOE/NV--372, REV. 3, Las Vegas, NV.

U.S. Department of Energy, National Nuclear Security Administration Nevada Site Office. 2004a. Corrective Action Decision Document for Corrective Action Unit 140: Waste Dumps, Burn Pits, and Storage Area, Nevada Test Site, Nevada, Revision 1. DOE/NV--928-REV. 1, Las Vegas, NV. 
U.S. Department of Energy, National Nuclear Security Administration Nevada Site Office. 2004b. Corrective Action Plan for Corrective Action Unit 140: Waste Dumps, Burn Pits, and Storage Area, Nevada Test Site, Nevada. DOE/NV--963-REV. 2, Las Vegas, NV.

U.S. Environmental Protection Agency. 1994. Guidance for the Data Quality Objectives Process, EPA QA/G-4. Washington D.C.

U.S. Environmental Protection Agency. 1996. Test Methods for Evaluating Solid Waste, Physical/Chemical Methods, SW-0846 CD ROM PB97-501928GEI, which contains updates for 1986, 1992, 1994, and 1996. Washington D.C.

U.S. Environmental Protection Agency. 1999. Contract Laboratory Program National Functional Guidelines for Organic Data Review, EPA540/R-99/008. Washington D.C. 


\section{APPENDIX A*}

\section{DATA QUALITY OBJECTIVES}

* As presented and published in the approved Corrective Action Investigation Plan for Corrective Action Unit 140: Waste Dumps, Burn Pits, and Storage Area, Nevada Test Site, Nevada, 2002, DOE/NV--826. Las Vegas, NV. 
Closure Report - CAU 140

Section: Appendix A

Revision: 0

Date: August 2005

THIS PAGE INTENTIONALLY LEFT BLANK 


\section{A.1.0 Seven-Step DQO Process for Phase I Investigation}

The DQO process is a strategic planning approach based on the scientific method that is used to prepare for site characterization data collection. The DQOs are designed to ensure that the data collected will provide sufficient and reliable information to identify, evaluate, and technically defend potentially viable corrective actions (i.e., no further action, closure in place, or clean closure). The existing information about the nature and extent of contamination at the nine CASs in CAU 140 is insufficient to evaluate and select preferred corrective actions, except for CAS 05-23-01, Gravel Gertie, which will be closed in place. The CAU 140 investigation will be based on DQOs developed by representatives of the NDEP and the NNSA/NV.

Nine CASs comprise CAU 140. Seven CASs are in Area 5, one CAS is in Area 22, and one CAS is in Area 23. The nine CASs are:

- 05-08-01, Detonation Pits

- 05-08-02, Debris Pits

- 05-17-01, Hazardous Waste Accumulation Site (Buried)

- 05-19-01, Waste Disposal Site

- 05-23-01, Gravel Gertie

- 05-35-01, Burn Pit

- 05-99-04, Burn Pit

- 22-99-04, Radioactive Waste Dump

- 23-17-01, Hazardous Waste Storage Area

This section presents the seven-step DQO process for a Phase I investigation. All CASs will begin with Phase I. If a COPC is detected in any sample at a concentration above a PAL, the COPC will be identified as a $\mathrm{COC}$. If a $\mathrm{COC}$ is identified, the $\mathrm{CAS}$ containing that $\mathrm{COC}$ will undergo Phase II for the detected COCs, as presented in Section A.2.0.

\section{A.1.1 Step 1 - State the Problem}

This step identifies the DQO planning team members, describes the problem that has initiated the CAU 140 investigation, and develops a CSM. 


\section{A.1.1.1 Planning Team Members}

Page $A-2$ of $A-47$

The DQO planning team consists of representatives from NDEP, NNSA/NV, ITLV, and BN. The primary decision-makers include NDEP and NNSA/NV representatives. Table A.1-1 lists representatives, from each organization in attendance for the March 21, 2002, DQO Kickoff meeting.

Table A.1-1

DQO Meeting Participants

\begin{tabular}{|c|c|}
\hline Participant & Affiliation \\
\hline Steven Adams & ITLV \\
\hline Jill Dale & ITLV \\
\hline Gregory Doyle & BN \\
\hline Angela Dudley & ITLV \\
\hline Tom Fitzmaurice & BN \\
\hline Malu Gawthrop Cooper & ITLV \\
\hline Syl Hersh & ITLV \\
\hline Joe Hutchinson & ITLV \\
\hline Lynn Kidman & ITLV \\
\hline Sean Kosinski & NNSA/NV \\
\hline John Nicklas & ITLV \\
\hline Milinka Watson-Garrett & ITLV \\
\hline Dave Weston & ITLV \\
\hline Dustin Wilson & ITLV \\
\hline Clem Goewert & NDEP \\
\hline
\end{tabular}

BN - Bechtel Nevada

ITLV - IT Corporation, Las Vegas Office

NDEP - Nevada Division of Environmental Protection

NNSA/NV - U.S. Department of Energy, National Nuclear Security Administration

Nevada Operations Office

\section{A.1.1.2 Describe the Problem}

Corrective Action Unit 140 is being investigated because:

- Disposed waste may be present without appropriate controls (i.e., use restrictions, adequate cover). 
- Hazardous and/or radioactive constituents may be present at concentrations and locations that could potentially pose a threat to human health and the environment.

\section{A.1.1.3 Develop Conceptual Site Model}

Conceptual Site Models describe the most probable scenarios for current conditions at specific sites and define the assumptions that are the basis for identifying appropriate sampling strategy and data collection methods. Accurate CSMs are important as they serve as the basis for all subsequent inputs and decisions throughout the DQO process.

An important element of a CSM is the expected fate and transport of contaminants, which infer how contaminants move through site media and where they can be expected in the environment. The expected fate and transport is based on distinguishing physical characteristics of the contaminants and media. Contaminant characteristics include solubility, density, and particle size. Media characteristics include permeability, saturation, sorting, chemical composition, and adsorption coefficients. In general, contaminants with low solubility and high density can be expected to be found relatively close to release points. Contaminants with high solubility and low density can be expected to be found further from release points or in areas where settling may occur.

Migration of contaminants to groundwater is limited to the geophysical properties such as permeability, porosity, and hydrologic conductivity. The presence of a hardpan layer (i.e., caliche) at some of the CASs would limit vertical migration of contaminants. Groundwater contamination is not considered a likely scenario at CAU 140 based on the following information:

- Area 5 - Depth to groundwater is approximately 600 to $800 \mathrm{ft}$ depending upon the specific CAS (DOE/NV, 1986)

- Area 22 - Depth to groundwater is about $800 \mathrm{ft}$ (USGS, 1964)

- Area 23 - Depth to groundwater is about 1,150 ft (DOE/NV, 1997); depth to perched water is about 500 and $1,080 \mathrm{ft}(\mathrm{BN}, 1997)$

Descriptions of the CASs are located in Section 2.0 of the CAIP and summarized below:

- CAS 05-08-01, Detonation Pits -- This CAS contains two surface detonation areas that measure approximately 4 by $15 \mathrm{ft}$. Additionally, there are three trenches (3- to 4-ft deep) located at the far end of the CAS. 
- CAS 05-08-02, Debris Pits -- This CAS contains an area that resembles an evaporation pond. Surface debris is scattered throughout the area.

- CAS 05-17-01, Hazardous Waste Accumulation Site (Buried) -- No buried debris is believed to be present at this CAS. A soil mound is located in the middle of the CAS, and a small amount of surface debris and staining is present.

- CAS 05-19-01, Waste Disposal Site -- This CAS consists of three noncontiguous areas. Each area contains debris. A portion of the western area has burned debris. The middle area contains both surface and buried debris. The surface debris is next to but not on top of the buried debris.

- CAS 05-23-01, Gravel Gertie -- This CAS consists of a test structure and surrounding area that may have been impacted by dispersion of contaminants. Debris associated with the structure is located at this CAS.

- CAS 05-35-01, Burn Pit -- This CAS has two burn stains. The CAS was originally thought to be a landfill; however, a geophysical survey indicated that buried debris is not present. Aerial photographs and walkovers identify a bermed area. The only surface debris present is some scattered charcoal.

- CAS 05-99-04, Burn Pit -- This CAS contains three surface burn areas and surface debris.

- CAS 22-99-04, Radioactive Waste Dump -- This CAS contains a bermed area of deteriorating sandbags. No debris, except the sandbags, is located at this CAS. The term "dump" is believed to have the military meaning of "storage," rather than disposal area.

- CAS 23-17-01, Hazardous Waste Storage Area -- This CAS consists of a former hazardous waste storage area that has been covered over by gravel and is used as a parking/storage lot. No debris is associated with the surface area. The CAS also has buried debris in landfill cells. The landfill cells are partially below a portion of the former storage area.

Three CSMs have been developed for CAU 140 using assumptions formulated from the physical setting, potential contaminant sources/release information, historical background information, and data from previous sampling efforts. The CSMs are termed Surface Material, Buried Debris, and Internal Structure. The applicability to the CSMs to each CAS is summarized in Table A.1-2.

\section{Future Land-Use Scenarios}

Future land-use scenarios limit future uses of the CASs to various nonresidential (i.e., industrial) uses (DOE/NV, 1998). The future land-use scenarios for CAU 140 are presented in Table A.1-3. 
Table A.1-2

Conceptual Site Models and Associated CASs

\begin{tabular}{|c|c|c|c|c|c|c|c|c|c|}
\hline Conceptual Site Models & $\begin{array}{l}\text { ' } \\
\text { o } \\
\text { o } \\
\text { மீ }\end{array}$ & $\begin{array}{l}\text { o } \\
0 \\
0 \\
0 \\
\text { ம் }\end{array}$ & $\frac{5}{\stackrel{1}{1}}$ & $\begin{array}{l}5 \\
\text { ơ } \\
\frac{1}{\dot{b}}\end{array}$ & 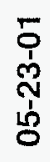 & $\begin{array}{l}\overline{0} \\
1 \\
0 \\
1 \\
1 \\
0\end{array}$ & $\begin{array}{l}\text { षे } \\
\text { ơ } \\
\text { के } \\
\text { ம் }\end{array}$ & $\begin{array}{l}\text { ષั } \\
\text { ò } \\
\text { Oे } \\
\text { ஸे }\end{array}$ & $\frac{5}{\stackrel{1}{\Lambda}}$ \\
\hline Surface Material & $\mathrm{x}$ & $x$ & $x$ & $x$ & $x$ & $x$ & $x$ & $x$ & $x$ \\
\hline Buried Debris & $x$ & & $x$ & $x$ & & & & & $x$ \\
\hline Internal Structure & & & & & $x$ & & & & \\
\hline
\end{tabular}

$X$ - The CSM applies to this CAS.

Table A.1-3

Future Land-Use Scenarios for CASs Within CAU 140

\begin{tabular}{|c|c|c|}
\hline CAS & Zone & Zone Description \\
\hline $05-19-01$ & $\begin{array}{l}\text { Research, Test, and } \\
\text { Experiment } \\
\text { Land-Use Zone }\end{array}$ & $\begin{array}{l}\text { Designated for small-scale research and development projects and } \\
\text { demonstrations; pilot projects; outdoor tests; and experiments for the } \\
\text { development, quality assurance, or reliability of material and equipment } \\
\text { under controlled conditions. Includes compatible defense and } \\
\text { nondefense research, development and testing projects and activities } \\
\text { (DOE/NV, 1998). }\end{array}$ \\
\hline $\begin{array}{l}05-08-01 \\
05-08-02 \\
05-17-01 \\
05-23-01 \\
05-99-04 \\
23-17-01\end{array}$ & $\begin{array}{l}\text { NTS Reserved } \\
\text { Land-Use Zone }\end{array}$ & $\begin{array}{l}\text { Includes land and facilities that provide widespread flexible support for } \\
\text { diverse short-term testing and experimentation. The reserved zone is } \\
\text { also used for short duration exercises and training such as nuclear } \\
\text { emergency response and Federal Radiological Monitoring and } \\
\text { Assessment Center training and DoD land-navigation exercises and } \\
\text { training (DOE/NV, 1998). }\end{array}$ \\
\hline $22-99-04$ & $\begin{array}{l}\text { Solar Enterprise, } \\
\text { Public Accessible } \\
\text { Land-Use Zone }\end{array}$ & $\begin{array}{l}\text { Designated for the development of a solar power generation facility, } \\
\text { and light industrial equipment, and commercial manufacturing } \\
\text { capability. This CAS is outside the security gate (DOE/NV, 1998). }\end{array}$ \\
\hline $05-35-01$ & $\begin{array}{l}\text { Radioactive Waste } \\
\text { Management } \\
\text { Land-Use Zone }\end{array}$ & $\begin{array}{l}\text { Designated for the management of radioactive wastes } \\
\text { (DOE/NV, 1998). }\end{array}$ \\
\hline
\end{tabular}


Exposure to contamination at sites within the NTS boundaries is limited to site workers. They may be exposed to COPCs through oral ingestion, inhalation, or dermal contact (absorption) of soils and/or debris (e.g., equipment, concrete) due to inadvertent disturbance of these materials.

\section{A.1.1.3.1 Surface Material Conceptual Site Model}

All nine CASs are included in the Surface Material CSM developed for CAU 140. Figure A.1-1 shows a generalized representation of the Surface Material CSM and the following text provides additional details to supplement the model.

According to historical documentation and interviews, instead of managing solid waste at one or two disposal sites, the practice was to manage solid waste in the vicinity of the activity. Waste was stored or burned from waste streams that included, but were not limited to, various combinations of construction debris, radioactive materials, explosives, and potentially hazardous wastes. Open burning was a common practice up to 1972. Waste was routinely soaked with diesel fuel and burned.

\section{CSM Parameters}

\section{Affected Media}

Surface and near-surface soils are the potentially affected media where solid and/or liquid material may have contributed contamination. Any contamination would be attributable to direct release to the surface, release of contaminants through burning activities, release of contaminants through aerial dispersion testing or munitions detonation, erosion of various contaminants off the surface of solid materials, and leaching of contaminants from materials.

\section{Location of Contamination/Release}

The surface soil at the CAU $140 \mathrm{CASs}$ is the most likely place to find contamination. At any sites (e.g., CAS 23-17-01) where a covering material (i.e., soil, gravel) has been added, the contamination is expected to be found below the covering. Contaminants at all of the CAU 140 CASs, regardless of physical or chemical characteristics, may be in the surface soil and any migration to the near-surface or subsurface is expected to be in a primarily vertical direction. 

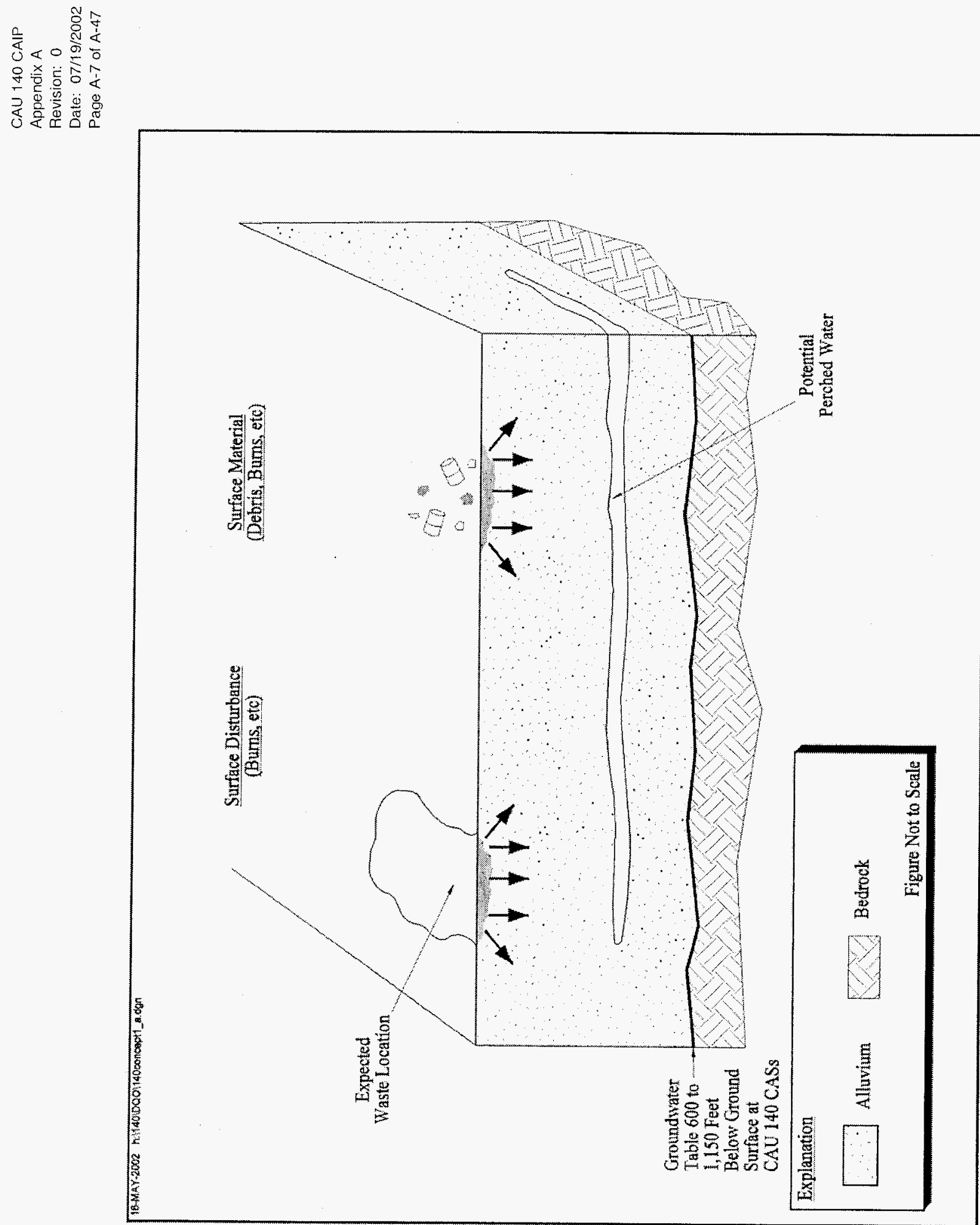

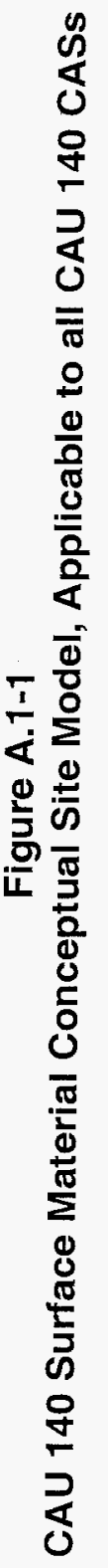


Aerial dispersion (e.g., CAS 05-23-01) would have initially occurred radially from the location of the detonation, with subsequent migration in the vertical direction.

\section{Transport Mechanisms}

The degree of contaminant migration at any of the sites is unknown, but is assumed to be minimal based on low precipitation and high evapotranspiration rates. Contaminants may have been transported by infiltration of precipitation through soil which serves as a driving force for downward migration of contaminants; however, the annual average precipitation on the valleys of the NTS ranges from 3 to $6 \mathrm{in}$. and on most of the ridges and the mesas of the NTS averages less than $10 \mathrm{in}$. per year. The potential annual evaporation from lake and reservoir surfaces was estimated to range from 60 to 82 in. per year, or roughly 5 to 25 times the annual precipitation (USGS, 1975). Grading or sloping at sites may cause a lateral migration prior to the vertical migration.

Wind direction at the time of release would have impacted aerial dispersion.

\section{Preferential Pathways}

None outside of the CSM.

\section{Surface Migration}

Surface migration may occur as a result of run-off, saltation, and grading. Surface migration is a biasing factor considered in the selection of sampling points.

\section{Lateral and Vertical Extent of Contamination}

Contamination, if present, is expected to be contiguous to the site. Concentrations are expected to decrease with distance and depth from the sites.

\section{COPCs/Released Material}

The COPCs are specific to each CAS and discussed individually in the following paragraphs. The COPCs and critical COPCs for the CAU 140 CASs are summarized in Table A.1-4.

CAS 05-08-01, Detonation Pits: The exact purpose of this site has not been identified; however, because one of the detonation pits is posted with signs that read "Caution Radioactive Material" and 
Table A.1-4

Phase I Contaminants of Potential Concern ${ }^{\text {a }}$

\begin{tabular}{|c|c|c|c|c|c|c|c|c|c|}
\hline COPC & $\begin{array}{l}5 \\
0 \\
1 \\
0 \\
1 \\
0 \\
0\end{array}$ & $\begin{array}{l}\text { } \\
0 \\
\infty \\
0 \\
0 \\
0 \\
0\end{array}$ & $\frac{5}{8}$ & 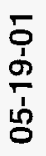 & 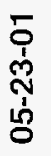 & $\begin{array}{l}\overline{0} \\
0 \\
0 \\
1 \\
0 \\
0\end{array}$ & $\begin{array}{l}8 \\
8 \\
1 \\
\delta \\
0 \\
1 \\
0 \\
0\end{array}$ & 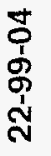 & $\frac{\Gamma}{\stackrel{1}{0}}$ \\
\hline \multicolumn{10}{|c|}{ Organics } \\
\hline Diesel/Gasoline/Petroleum Hydrocarbons & & C & $\mathrm{C}$ & $\mathrm{C}$ & & $\mathrm{C}$ & $\mathrm{C}$ & & $\mathrm{C}$ \\
\hline Ethylene Glycol & & & & & & & & & $\mathrm{C}$ \\
\hline Explosives Residue & $\mathrm{C}$ & & C & & $\mathrm{C}$ & & & & \\
\hline Herbicides & & & & & & & & & $\mathrm{C}$ \\
\hline PCBs & 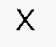 & $X$ & C & $X$ & $X$ & X & $X$ & $X$ & C \\
\hline Pesticides & & & $\mathrm{C}$ & & & & & & $\mathrm{C}$ \\
\hline Pyrolytic Oil ${ }^{b}$ & & & & $\mathrm{C}$ & & $\mathrm{C}$ & $\mathrm{C}$ & & \\
\hline SVOCs & $X$ & C & $\mathrm{C}$ & $x$ & & $x$ & $x$ & & $\mathrm{C}$ \\
\hline VOCs & $x$ & $\mathrm{C}$ & $C$ & $\mathrm{C}$ & & $x$ & $x$ & & $\mathrm{C}$ \\
\hline \multicolumn{10}{|c|}{ Metals } \\
\hline Antimony & & & & & C & & & & \\
\hline Beryllium & & & $\mathrm{C}$ & & & & & & \\
\hline Nickel and Zinc & & & & $\mathrm{C}$ & & $\mathrm{C}$ & C & & \\
\hline RCRA Metals & $x$ & $x$ & $\mathrm{C}$ & $\mathrm{C}$ & & $\mathrm{C}$ & $\mathrm{C}$ & & $\mathrm{C}$ \\
\hline \multicolumn{10}{|c|}{ Radionuclides } \\
\hline $\begin{array}{l}\text { Radionuclides (Isotopes are identified } \\
\text { in text) }\end{array}$ & $x$ & & & $x$ & $x$ & & & $x$ & $X$ \\
\hline
\end{tabular}

\footnotetext{
${ }^{\text {a }}$ For those COPCs identified that include multiple parameters, the parameters with PALs will be evaluated.

${ }^{\circ} \mathrm{By}$-product COPC from burning.

$C=$ Critical COPC $\quad X=C O P C$
}

because metal debris and shrapnel are scattered throughout the entire area, it is thought that CAS 05-08-01 may have been used for munitions detonation and storage. Three trenches located behind the observation area may have been used to store munitions. Surface staining was observed in the northern and southern trenches. The following specific COPCs identified for this CAS are based on process knowledge, interviews, historical documents, and field observations:

- Conventional explosives residue - based upon suspected explosives detonation and storage 
- RCRA Metals - based upon the limited amount of information available for this CAS

- Radionuclides - based upon radioactive contamination sign, cobalt-60, strontium-90, technetium-99, cesium-137, europium-154, europium-155, uranium-234, uranium-235, uranium-238, plutonium-239, plutonium-240, and americium-241

Although not identified as COPCs at this CAS, PCBs, VOCs, and SVOCs will be analyzed because they are common concerns at the NTS and have not been ruled out based upon process knowledge.

CAS 05-08-02, Debris Pits: Due to the lack of historical information, the original purpose or use of the site remains unknown. The site includes a small amount of surface and near surface debris (e.g., aerosol cans, paint cans, metal piping). The source of the debris is unknown. The large area that was mounded on all sides appears to resemble two ponds connected by a weir gate on the south side and an overflow pipe on the north side. No staining was observed.

If the area that resembles an evaporation pond was ever used as an evaporation pond, increased migration may have occurred in the vertical direction, impacting the transport mechanism.

The specific COPCs identified for this CAS are based on field observations:

- Fuel/Motor oil - based upon presence of filters

- SVOCs - based upon presence of debris

- VOCs - based upon presence of debris

Although not identified as COPCs at this CAS, PCBs and RCRA metals will be analyzed because they are common concerns at the NTS and have not been ruled out based upon process knowledge.

CAS 05-17-01, Hazardous Waste Accumulation Site (Buried): Although the term "buried" is part of the CAS description, no waste is believed to be buried at this site. This belief is based upon site visits and the lack of visual disturbance to the soil. Due to the lack of information found on this site, the original purpose or intended use of the site is unknown. Within the documentation found during the PA, the site is referred to as a hazardous waste accumulation site, explosives disposal site, CWD, waste dump/disposal site, contaminated waste site, and collapsed explosives bunker. Surface staining was observed within the CAS, indicating that materials may have been stored/released on the surface. No specific COPCs were identified for this site based on process knowledge, interviews, historical documentation, and field observations. Based upon the sites potential activities, COPCs may include: 
- Beryllium - based upon activities in this portion of Area 5

- Explosives residue - based upon reference to explosives bunker

- Chemicals (type and quantity undocumented, although may include VOCs, SVOCs, PCBs, petroleum hydrocarbons, and RCRA metals) - based upon potentially stored material

CAS 05-19-01, Waste Disposal Site: The potential exists that any of the activities at Frenchman Lake could have contributed wastes to the site. It is also possible that the site may have received radioactive wastes. A burned airplane was at the site, which may have been used for fire training activities. The majority of the visible debris at the site appears to be construction related debris, some of which has been burned on the surface. Geophysical results indicate the presence of buried debris. The following specific COPCs identified for this CAS are based on process knowledge, interviews, historical documents, and field observations:

- Diesel - typically used as a burning accelerant

- Nickel and zinc - by-product from burning activities

- Pyrolytic oil - by-product from burning activities

- RCRA metals - by-product from burning activities

- Radionuclides - based upon interviews and site surveys, cobalt-60, strontium-90, technetium-99, cesium-137, europium-154, europium-155, uranium-234, uranium-235, uranium-238, plutonium-239, plutonium-240, and americium-241

- VOCs - based upon presence of aerosol cans

Although not identified as COPCs at this CAS, PCBs and SVOCs will be analyzed because they are common concerns at the NTS and have not been ruled out based upon process knowledge.

Note: Pyrolytic oil, a by-product from burning activities, consists of naphthalenes, anthracene, benzenes, thiazoles, amines, ethyl benzene, toluene, and other hydrocarbons (CIWMB, 2001).

CAS 05-23-01, Gravel Gertie: Sandia National Laboratories used the structure for three tests in 1957 to test the ability to minimize contamination in the event of an accidental explosion associated with chemical explosives and nuclear material. The three tests involved $\mathrm{HE}$ and in the last two, uranium was used as a tracer material (Sandia Corporation, 1964). The structure (see Section A.1.1.3.3) was 
also used for similar testing in 1982, which involved HE, DU, and antimony oxide (Metcalf, 2002). A great deal of information was found during the PA on the 1957 and 1982 testing of the Gravel Gertie; no information was found regarding use of the structure for any other operations. The following specific COPCs identified for this CAS are based on process knowledge, interviews, historical documents, and field observations:

- Radionuclides - based upon presence of radioactive material during testing, cobalt-60, strontium-90, technetium-99, cesium-137, europium-154, europium-155, uranium-234, uranium-235, uranium-238, plutonium-239, plutonium-240, and americium-241

- Antimony - based upon presence antimony oxide during testing

- High explosives - based upon detonation, the HE is only applicable to the Internal Structure CSM (Section A.1.1.3.3) as any explosive material transported to the atmosphere would have been consumed in the detonation

Although not identified as a COPC at this CAS, PCBs will be analyzed because it is a common concern at the NTS and has not been ruled out based upon process knowledge.

CAS 05-35-01, Burn Pit: No historical information has been found regarding the use of this site as a burn pit, or for any other use. Also, no documentation has been located which identifies the dates of operation for this site. Field observations include charcoal wood and stained soil typical of burning activities. The burn area was likely covered at one time and a current dirt road runs across part of the site. General historical documentation and interviews identify diesel as an accelerant for starting the burns. Geophysical survey indicated no buried waste.

The dirt road that runs through CAS 05-35-01 is sprayed with water for dust control. This activity is not expected to significantly contribute to vertical migration or alter the transport mechanism. The following specific COPCs identified for this CAS are based on process knowledge, and field observations:

- Diesel fuel - typically used as a burning accelerant

- Nickel and zinc - by-product from burning activities

- Pyrolytic oil - by-product from burning activities

- RCRA metals - by-product from burning activities 
Although not identified as COPCs at this CAS, PCBs, VOCs, and SVOCs will be analyzed because they are common concerns at the NTS and have not been ruled out based upon process knowledge.

CAS 05-99-04, Burn Pit: The term "pit" may be misleading as the burning appears to have been surface burning. The site includes three burn areas. The ground surface of the burn pit area contains burned tires, metal debris, wire, broken glass, concrete piles, and a gravel pile. The ground surface and vegetation are relatively undisturbed. Diesel fuel is believed to have been used as an accelerant at the site. The following specific COPCs identified for this CAS are based on process knowledge, interviews, historical documents, and field observations:

- Diesel fuel - typically used as a burning accelerant

- Pyrolytic oil - by-product from burning activities

- Nickel and zinc - by-product from burning activities

- RCRA Metals - by-product from burning activities

Although not identified as COPCs at this CAS, PCBs, VOCs, and SVOCs will be analyzed because they are common concerns at the NTS and have not been ruled out based upon process knowledge.

CAS 22-99-04, Radioactive Waste Dump: This site is presumed to have been used for radioactive source material storage based upon the use of the word "dump" to signify "storage" by the Army. The site is assumed to have been in operation from 1951 through 1958, and potentially as late as 1964. Historical documentation indicates that radioactive sources and material were stored at Camp Desert Rock. No documentation has been identified in the investigation to indicate that radioactive waste was disposed of at this site. A geophysical survey indicated no buried waste. No specific COPCs were identified for this site based on process knowledge, interviews, historical documentation, and field observations. COPCs typically associated with radiation sources of the era are:

- Radionuclides - based upon storage of radioactive source material, chlorine-36, cobalt-60, strontium-90, technetium-99, cesium-137, and thorium-232

Although not identified as a COPC at this CAS, PCBs will be analyzed because it is a common concern at the NTS and has not been ruled out based upon process knowledge. 
CAS 23-17-01, Hazardous Waste Storage Area: Waste was originally stored on the ground without any lining between the waste containers and soil. It was noted that material had been released to the ground and subsequently cleaned up. No sample results were found to confirm clean up. The area has since been covered by gravel and is currently used as a parking and storage area for sanitary waste management activities. The following specific COPCs identified for this CAS are based on process knowledge, interviews, historical documents, and field observations:

- Herbicides - based upon potential waste stored

- PCBs - based upon potential waste stored

- Pesticides - based upon potential waste stored

- Petroleum hydrocarbons - based upon potential waste stored

- Radionuclides - based upon storage of scintillation cocktail waste, tritium

- RCRA metals - based upon potential waste stored

- SVOCs - based upon potential waste stored

- VOCs - based upon potential waste stored

\section{A.1.1.3.2 Buried Debris Conceptual Site Model}

The Buried Debris CSM applies to CAS 05-19-01 and 23-17-01. It is believed that neither CAS 05-08-01 nor CAS 05-17-01 have buried debris. A trench will be made through the gravel/rock path and the collapsed mound, respectively, to confirm this belief. The Buried Debris CSM will be applied to CAS 05-08-01 and/or CAS 05-17-01, if buried debris is found. Should the presence of buried debris be detected at any other site, this CSM will be applied.

Figure A.1-2 shows a representation of the Buried Debris CSM, and the following text provides additional details to supplement the model. The Buried Debris CSM is in addition to the Surface Material CSM (described in Section A.1.1.3.1) for these CASs.

Near-surface and subsurface soils are the potentially affected media where solid and/or liquid waste may have contributed contamination. Any contamination would be attributable to direct release to the subsurface of liquid waste or leaching of contaminants off the surface of the buried materials. The amount of leachate generated is unknown, but is assumed to be minimal based on low precipitation and high potential evapotranspiration rates. 


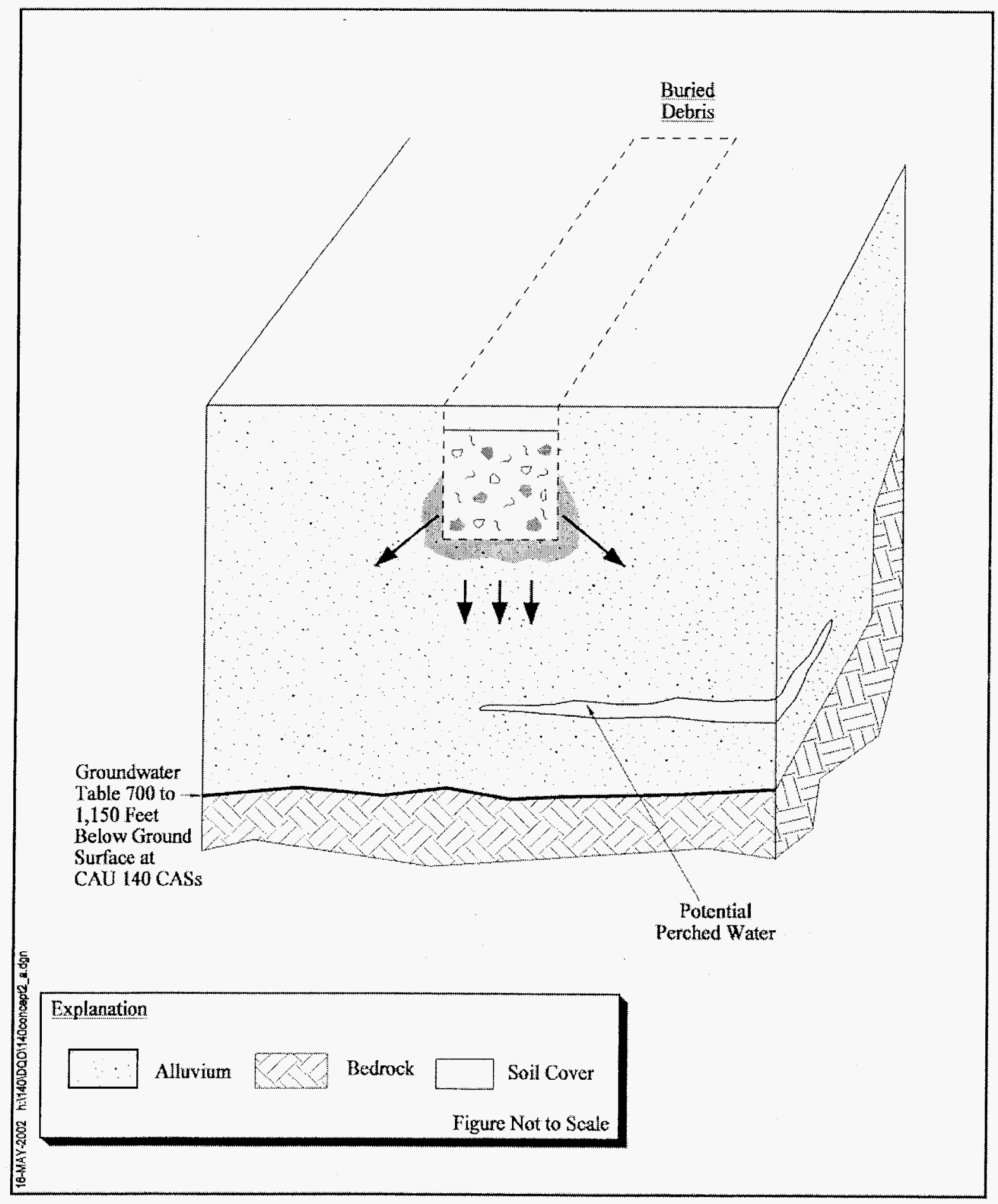

Figure A.1-2

CAU 140 Buried Debris Conceptual Site Model, Applicable to CASs 05-08-01, 05-17-01, 05-19-01, and 23-17-01 


\section{CSM Parameters}

Affected media includes near-surface and subsurface soil surrounding buried debris.

\section{Location of Contamination/Release}

Any contaminants at these CASs released to the affected media, regardless of physical or chemical characteristics, are expected directly beneath the buried debris and to the immediate lateral area.

\section{Transport Mechanisms}

Contaminants may have been transported by infiltration of precipitation through soil which serves as a driving force for downward migration of contaminants; however, the annual average precipitation on the valleys of the NTS ranges from 3 to 6 in. and on most of the ridges and mesas of the NTS averages less than 10 in. per year. The potential annual evaporation from lake and reservoir surfaces was estimated to range from 60 to 82 in. per year, or roughly 5 to 25 times the annual precipitation. (USGS, 1975)

\section{Preferential Pathways}

None outside of the CSM.

\section{Lateral and Vertical Extent of Contamination}

Contamination, if present, is expected to be contiguous to the site. Concentrations are expected to decrease with distance and depth from the site.

\section{COPCs/Released Material}

CAS 05-19-01, Waste Disposal Site: A geophysical survey indicated that buried waste is present in the Middle Disposal Area of CAS 05-19-01. The potential exists that any of the activities at Frenchman Lake could have contributed wastes to the site. Additional information regarding the COPCs and released material is presented in Section A.1.1.3.1.

CAS 23-17-01, Hazardous Waste Storage Area: Geophysical survey results indicate that buried waste is present at CAS 23-17-01. Additional information regarding the COPCs and released material is presented in Section A.1.1.3.1. 


\section{A.1.1.3.3 Internal Structure Conceptual Site Model}

Page $\mathrm{A}-17$ of $\mathrm{A}-47$

The Internal Structure CSM is applicable to CAS 05-23-01. Figure A.1-3 shows a representation of the CSM, and the following text provides additional details to supplement the model. The Internal Structure CSM is in addition to the Surface Material CSM (surface release from aerial dispersion).

\section{CSM Parameters}

\section{Affected Media}

Affected media includes the concrete walls, floor, and the gravel/soil making up the roof of the Gravel Gertie.

\section{Location of Contamination/Release}

The floor, walls, and roof in the detonation and adjoining corridors/rooms of the Gravel Gertie, along with the gravel in the roof of the Gravel Gertie, are the most likely places to find contamination. The contamination may have moved further into the roof of the Gravel Gertie during the detonation due to the inherent design of the structure.

\section{Transport Mechanisms}

It is unlikely that contaminants would have been transported by infiltration of precipitation through the Gravel Gertie as the annual average precipitation on the valleys of the NTS ranges from 3 to 6 in., and on most of the ridges and mesas of the NTS averages less than $10 \mathrm{in}$. per year. The potential annual evaporation from lake and reservoir surfaces was estimated to range from 60 to 82 in. per year, or roughly 5 to 25 times the annual precipitation (USGS, 1975), and the structure of the Gravel Gertie protects against runon.

\section{Preferential Pathways}

None outside of the CSM.

\section{Lateral and Vertical Extent of Contamination}

Contamination, if present, is expected to be contiguous to the site. Concentrations are expected to decrease with distance from the detonation point. 


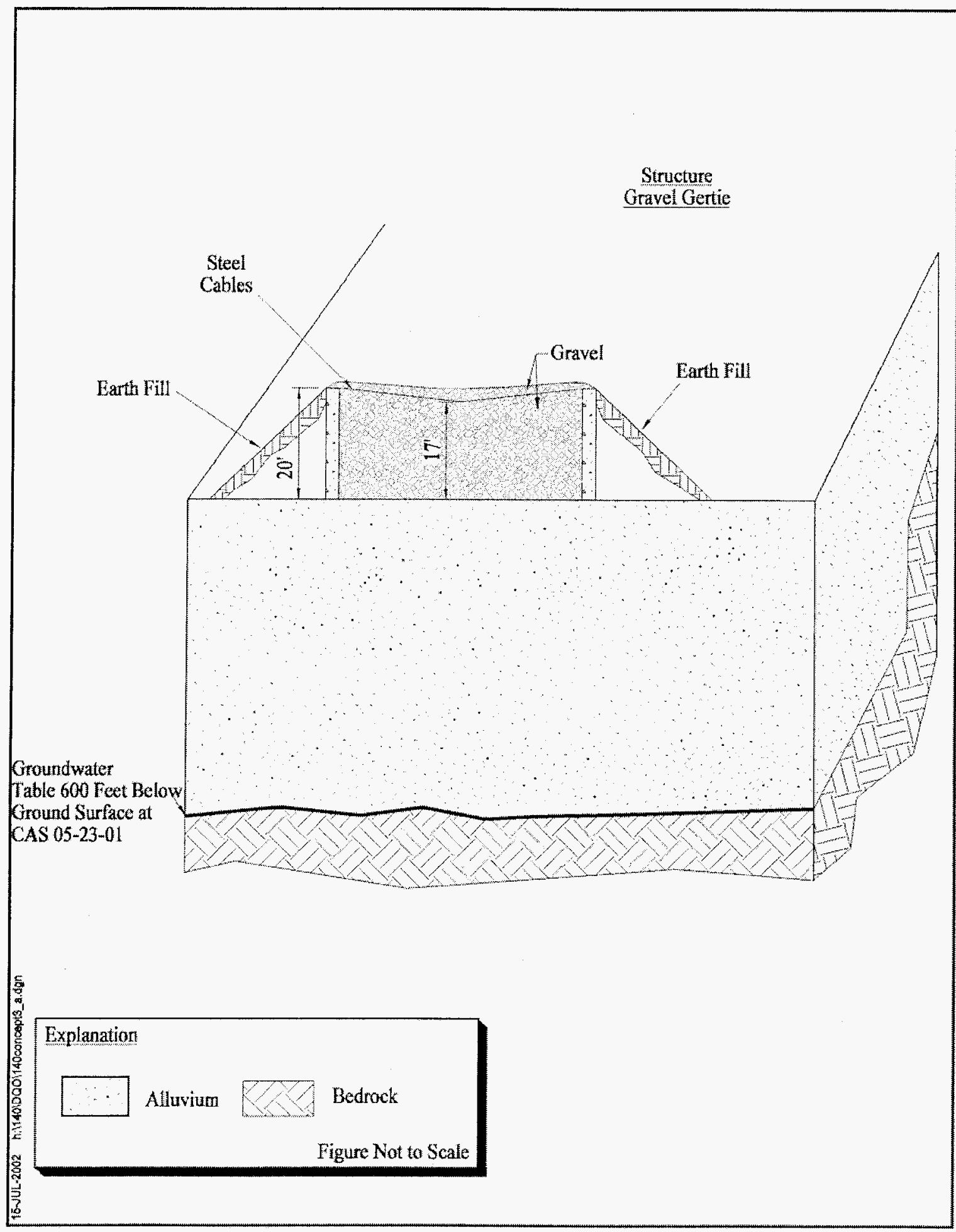

Figure A.1-3

CAU 140 Internal Structure Conceptual Site Model, Applicable to CAS 05-23-01 


\section{COPCs/Released Materials}

CAS 05-23-01, Gravel Gertie: Sandia National Laboratories used the Gravel Gertie for three tests in 1957 to test the ability to minimize contamination in the event of an accidental explosion associated with chemical explosives and nuclear material. The three tests involved $\mathrm{HE}$, and in the last two uranium was used as a tracer material. The structure was also used for similar testing in 1982, which allegedly involved $\mathrm{HE}$ and DU. It was believed that uranium would be trapped within the gravel. Additional information regarding the COPCs and released material is presented in Section A.1.1.3.1.

\section{A.1.2 Step 2 - Identify the Decision}

This step develops a decision statement and defines alternative actions. The following subsections identify decisions and alternative actions appropriate for Phase I.

\section{A.1.2.1 Develop a Decision Statement}

The decision statement for Phase I is "Determine if a COC is present."

\section{A.1.2.2 Alternative Actions to the Decision}

If a COC is not present, further assessment of the CAS is not required. If a COC is present, initiate Phase II.

\section{A.1.3 Step 3 - Identify the Inputs to the Decision}

This step identifies the information needed, determines sources for information, determines the basis for establishing the action level, and identifies sampling and analysis methods that can meet the data requirements. To determine if a COC is present, each sample result is compared to the PAL (Section A.1.3.2). If any sample result is greater than the PAL, then the applicable CAS is advanced to Phase II for that analyte. This approach does not use a statistical mean/average for comparison to the PAL, but rather the individual result, to identify COCs.

\section{A.1.3.1 Information Needs and Information}

In order to determine if a COC is present at a particular CAS, sample data must be collected and analyzed following these two criteria: (1) samples must be collected in areas most likely to contain a 
COC and (2) the analytical suite selected must be sufficient to detect any COCs present in the samples. Biasing factors to support these criteria include:

- Documented process knowledge on source and location of release

- Field observations

- Geophysical surveys

- Radiological surveys

- Historical sample results

- Experience and data from investigations of similar sites

- Professional judgement

Table A.1-5 lists the information needs, the source of information for each need, and the proposed methods to collect the data. The last column addresses, the QA/QC data type and associated metric. The data type is determined by the intended use of the resulting data in decision making. Data types are discussed in the following text.

All data to be collected are classified into one of three measurement quality categories: quantitative, semiquantitative, and qualitative. The categories for measurement quality are defined below.

\section{Quantitative Data}

Quantitative data results from direct measurement of a characteristic or component within the population of interest. These data require the highest level of QA/QC in collection and measurement systems because the intended use of the data is to resolve primary decision (i.e., rejecting or accepting the null hypothesis) and/or verifying closure standards have been met. Laboratory analytical data are usually assigned as quantitative data.

\section{Semiquantitative Data}

Semiquantitative data is generated from a measurement system that indirectly measures the quantity or amount of a characteristic or component of interest. Inferences are drawn about the quantity or amount of a characteristic or component because a correlation has been shown to exist between results from the indirect measurement and the quantitative measurement. The QA/QC requirements on semiquantitative collection and measurement systems are high but may not be as rigorous as a quantitative measurement system. Semiquantitative data contribute to decision making, but are not 
Table A.1-5

Information Needs to Resolve the Phase I Decision

\begin{tabular}{|c|c|c|c|}
\hline $\begin{array}{l}\text { Information } \\
\text { Need }\end{array}$ & Information Source & Collection Method & Data Type/Metric \\
\hline \multicolumn{4}{|c|}{$\begin{array}{l}\text { Decision I: Determine if a COC is present. } \\
\text { Criteria I: Samples will be collected in areas most likely to conta in a COC. }\end{array}$} \\
\hline \multirow{6}{*}{$\begin{array}{l}\text { Source and } \\
\text { location of } \\
\text { release points }\end{array}$} & $\begin{array}{l}\text { Process knowledge compiled } \\
\text { during the PA process and } \\
\text { previous investigations of } \\
\text { similar sites }\end{array}$ & $\begin{array}{l}\text { Information } \\
\text { documented in CSM } \\
\text { and public reports - } \\
\text { no additional data } \\
\text { needed }\end{array}$ & $\begin{array}{l}\text { Qualitative - CSM has not been } \\
\text { shown to be inaccurate }\end{array}$ \\
\hline & $\begin{array}{l}\text { Site visit and field } \\
\text { observations }\end{array}$ & $\begin{array}{l}\text { Conduct site visits } \\
\text { and document field } \\
\text { observations }\end{array}$ & $\begin{array}{l}\text { Qualitative - CSM has not been } \\
\text { shown to be inaccurate }\end{array}$ \\
\hline & Geophysical surveys & $\begin{array}{l}\text { Review and interpret } \\
\text { geophysical surveys }\end{array}$ & $\begin{array}{l}\text { Semiquantitative - Sampling } \\
\text { based on biasing criteria } \\
\text { stipulated in DQO Step } 7\end{array}$ \\
\hline & Radiological surveys & $\begin{array}{l}\text { Review and interpret } \\
\text { radiological surveys }\end{array}$ & $\begin{array}{l}\text { Semiquantitative - Sampling } \\
\text { based on biasing criteria } \\
\text { stipulated in DQO Step } 7\end{array}$ \\
\hline & Biased Samples & $\begin{array}{l}\text { Selection of locations } \\
\text { utilizing technical } \\
\text { expertise }\end{array}$ & $\begin{array}{l}\text { Semiquantitative - Sampling } \\
\text { based on process knowledge }\end{array}$ \\
\hline & $\begin{array}{l}\text { Systematic biased samples, } \\
\text { utilized when observable } \\
\text { biasing factors are not } \\
\text { present }\end{array}$ & $\begin{array}{l}\text { Generate sampling } \\
\text { points based on CAS } \\
\text { grid }\end{array}$ & $\begin{array}{l}\text { Semiquantitative - Sampling } \\
\text { based on CAS borders }\end{array}$ \\
\hline \multicolumn{4}{|c|}{$\begin{array}{l}\text { Decision I: Determine if a COC is present. } \\
\text { Criteria 2: Analyses must be sufficient to detect any COCs in samples. }\end{array}$} \\
\hline $\begin{array}{l}\text { Identification of } \\
\text { all potential } \\
\text { contaminants }\end{array}$ & $\begin{array}{l}\text { Process knowledge compiled } \\
\text { during PA process and } \\
\text { previous investigations of } \\
\text { similar sites }\end{array}$ & $\begin{array}{l}\text { Information } \\
\text { documented in CSM } \\
\text { and public reports - } \\
\text { no additional data } \\
\text { needed }\end{array}$ & $\begin{array}{l}\text { Qualitative - CSM has not been } \\
\text { shown to be inaccurate }\end{array}$ \\
\hline $\begin{array}{l}\text { Analytical } \\
\text { results }\end{array}$ & $\begin{array}{l}\text { Data packages of biased } \\
\text { samples }\end{array}$ & $\begin{array}{l}\text { Appropriate sampling } \\
\text { techniques and } \\
\text { approved analytical } \\
\text { methods will be used }\end{array}$ & $\begin{array}{l}\text { Quantitative - Validated } \\
\text { analytical results will be } \\
\text { compared to PALs }\end{array}$ \\
\hline
\end{tabular}


generally used alone to resolve primary decisions. The data are often used to guide investigations toward quantitative data collection.

\section{Qualitative Data}

Qualitative data identifies or describes the characteristics or components of the population of interest. The QA/QC requirements for qualitative data are the least rigorous on data collection methods and measurement systems. Professional judgement is often used to generate qualitative data. The intended use of the data is for information purposes, to refine conceptual models, and guide investigations rather than resolve primary decisions. This measurement of quality is typically associated with historical information and data where QA/QC may be highly variable or not known.

Metrics provide a tool to determine if the collected data support decision making as intended. Metrics tend to be numerical for quantitative and semiquantitative data, and descriptive for qualitative data.

\section{A.1.3.2 Determine the Basis for the Preliminary Action Levels}

Site workers may be exposed to contaminants through oral ingestion, inhalation, external (radiological), or dermal contact (absorption) of soil during disturbance of this media. Laboratory analytical results for soils will be compared to the following PALs to evaluate if COPCs are present at levels that may pose an unacceptable risk to human health and/or the environment:

- EPA Region IX Risk-Based Preliminary Remediation Goals for Industrial Soils (EPA, 2000).

- Background concentrations for metals when natural background exceeds the PRG, as is often the case with arsenic. Background is considered the mean plus two times the standard deviation of the mean for sediment samples collected by the Nevada Bureau of Mines and Geology throughout the Nellis Air Force Range (NBMG, 1998; Moore, 1999).

- TPH action level of $100 \mathrm{mg} / \mathrm{kg}$ per the NAC 445A.2272 (NAC, 2002).

- The PALs for radionuclides are isotope-specific and defined as the maximum concentration for that isotope found in samples from undisturbed background locations in the vicinity of the NTS (McArthur and Miller, 1989; US Ecology and Atlan-Tech, 1992; Black and Townsend, 1996). The PAL for chlorine-36 is based upon a 25 millirem per year ( $\mathrm{mrem} / \mathrm{yr}$ ) screening level and an industrial sites land use scenario (NCRP, 1999 and Adams, 2002). 


\section{A.1.3.3 Potential Sampling Techniques and Appropriate Analytical Methods Radiological Surveys}

Radiological surveys were used to determine presence/lateral extent of applicable waste. Radiological surveys followed standard procedures. Further information is provided in Section A.1.7.1.

\section{Soil Sampling}

Augering, direct push, excavation, drilling, or other appropriate sampling methods will be used. Sample collection and handling activities will follow standard procedures.

Section 6.0 of the CAIP provides analytical methods and laboratory requirements (e.g., detection limits, precision, and accuracy). Sample volumes are laboratory-and method-specific and will be determined in accordance with laboratory requirements. Specific analyses required for the disposal of IDW are identified in Section 5.0 of this CAIP.

To assure that laboratory analyses are sufficient to detect contamination in soil samples at concentrations exceeding the MRL, Phase I chemical and/or radiological parameters of interest have been selected for each CAS. The analyses for each CAS are identified in Table A.1-6.

The VOC and SVOC compounds expected to be analyzed for Phase I are included in Tables A.1-7 and A.1-8, respectively. The herbicide and pesticide compounds expected to be analyzed for Phase I are listed in Table A.1-9. The compounds expected to be analyzed for Phase $\mathrm{I}$ for explosives, polyaromatic hydrocarbons (PAH), PCBs, and pyrolytic oil are included in Table A.1-10.

\section{A.1.4 Step 4, Define the Boundaries of the Study}

The purpose of this step is to define the target population of interest, specify the spatial and temporal features of the population that are pertinent for decision making, determine practical constraints on data collection, and define the scale of decision making relevant to target populations. 
Table A.1-6

Phase I Analyses per CAS

\begin{tabular}{|c|c|c|c|c|c|c|c|c|c|}
\hline Analyses & $\begin{array}{l}5 \\
0 \\
1 \\
0 \\
0 \\
1 \\
1\end{array}$ & $\begin{array}{l}N \\
0 \\
\infty \\
0 \\
0 \\
1 \\
0\end{array}$ & $\frac{5}{\frac{1}{1}}$ & 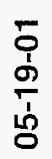 & 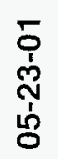 & 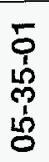 & 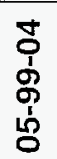 & 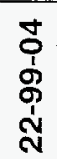 & $\frac{\bar{\sigma}}{\frac{1}{2}}$ \\
\hline \multicolumn{10}{|c|}{ Organics } \\
\hline VOC & $x$ & $x$ & $x$ & $x$ & & $x$ & $x$ & & $x$ \\
\hline SVOC & $x$ & $x$ & $x$ & $x$ & & $x$ & $x$ & & $x$ \\
\hline Pyrolytic oil ${ }^{b}$ & & & & $x$ & & $x$ & $x$ & & \\
\hline Ethylene Glycol & & & & & & & & & $x$ \\
\hline Explosives & $x$ & & $x$ & & $x$ & & & & \\
\hline Herbicides & & & & & & & & & $x$ \\
\hline Pesticides & & & $x$ & & & & & & $x$ \\
\hline PCB & $x$ & $x$ & $x$ & $x$ & $x$ & $x$ & $x$ & $x$ & $x$ \\
\hline $\begin{array}{l}\text { TPH (Diesel- and Gasoline-Range } \\
\text { Organics [C6-C38]) }\end{array}$ & & $\mathrm{X}$ & $x$ & $x$ & & $X$ & $x$ & & $x$ \\
\hline \multicolumn{10}{|c|}{ Metals } \\
\hline Total Antimony & & & & & $x$ & & & & \\
\hline Total Beryllium & & & $x$ & & & & & & \\
\hline Total Nickel, Zinc & & & & $x$ & & $x$ & $x$ & & \\
\hline Total RCRA Metals & $x$ & $x$ & $x$ & $x$ & & $x$ & $x$ & & $x$ \\
\hline \multicolumn{10}{|c|}{ Radionuclides } \\
\hline Gross Beta $^{\mathrm{C}}$ & & & & & & & & $x$ & \\
\hline Gamma Spectrometry ${ }^{\mathrm{d}}$ & $x$ & & & $x$ & $x$ & & & $x$ & \\
\hline Isotopic Uranium & $x$ & & & $x$ & $x$ & & & & \\
\hline Isotopic Plutonium & $x$ & & & $x$ & $x$ & & & & \\
\hline Technetium-99 & $X^{d}$ & & & $X^{d}$ & $X^{d}$ & & & $x$ & \\
\hline Strontium-90 & $x$ & & & $x$ & $x$ & & & $x$ & \\
\hline Tritium & & & & & & & & & $x$ \\
\hline
\end{tabular}

${ }^{a}$ For those analyses identified that include multiple parameters, the parameters with PALs will be evaluated.

${ }^{b}$ For the analyses requested for pyrolytic oil, see Table A. $1-10$.

${ }^{\circ}$ The determination as to whether chlorine-36 is advanced to Phase II will occur if gross beta results exceed the chlorine-36 PAL. In the event that a gamma spectrometry result is above the PAL, technetium will be analyzed on the first set of samples collected during Phase II. It is not necessary to analyze for technetium during Phase I because technetium (i.e., cesium-137) will not be present without gamma-emitting radionuclides also being present above PALs.

$X=$ Analyses 
Table A.1-7

Proposed VOCs for Analyses

\begin{tabular}{|c|c|c|}
\hline $\begin{array}{l}\text { 1,1,1-Trichloroethane } \\
\text { 1,1,1,2-Tetrachloroethane } \\
\text { 1,1,2,2-Tetrachloroethane } \\
\text { 1,1,2-Trichloroethane } \\
\text { 1,1-Dichloroethane } \\
\text { 1,1-Dichloroethene } \\
\text { cis-1,2-Dichloroethene } \\
\text { trans-1,2-Dichloroethene } \\
\text { 1,2-Dichloroethane } \\
\text { 1,2-Dichloropropane } \\
\text { 1,2,3-Trichloropropane } \\
\text { 1,2,4-Trimethylbenzene } \\
\text { 1,2-Dibromo-3-chloropropane } \\
\text { 1,2-Dibromoethane } \\
\text { 1,3,5-Trimethylbenzene } \\
\text { cis-1,3-Dichloropropene } \\
\text { trans-1,3-Dichloropropene } \\
\text { 2-Butanone } \\
\text { 2-Chlorotoluene }\end{array}$ & $\begin{array}{l}\text { 4-Methyl-2-pentanone } \\
\text { Acetone } \\
\text { Benzene } \\
\text { Bromobenzene } \\
\text { Bromochloromethane } \\
\text { Bromodichloromethane } \\
\text { Bromoform } \\
\text { Bromomethane } \\
\text { Carbon disulfide } \\
\text { Carbon tetrachloride } \\
\text { Chlorobenzene } \\
\text { Chloroethane } \\
\text { Chloroform }\end{array}$ & $\begin{array}{l}\text { Chloromethane } \\
\text { Dibromochloromethane } \\
\text { Dibromomethane } \\
\text { Dichlorodifluoromethane } \\
\text { Ethylbenzene } \\
\text { Isopropylbenzene } \\
\text { Methyl tertiary butyl ether } \\
\text { Methylene chloride } \\
\text { N-Butylbenzene } \\
\text { N-Propylbenzene } \\
\text { sec-Butylbenzene } \\
\text { Styrene } \\
\text { tert-Butylbenzene } \\
\text { Tetrachloroethene } \\
\text { Toluene } \\
\text { Trichloroethene } \\
\text { Trichlorofluoromethane } \\
\text { Trichlorotrifluoroethane } \\
\text { Vinyl acetate } \\
\text { Vinyl chloride } \\
\text { Xylene }\end{array}$ \\
\hline
\end{tabular}

\section{A.1.4.1 Define the Target Population}

The target populations represent locations within the CAS that will contain COCs if present. The target populations are dependent upon the CSM(s) applicable to the CAS. In identifying the target populations, the Surface Material CSM is further subdivided (Table A.1-11), better describing site conditions and more accurately defining sampling requirements and, hence, sampling locations. Contaminants in the Surface Material CSM would "act" the same, although there are different circumstances:

- Surface debris

- Surface release (some releases may have been fully or partially removed)

- Surface refuse burning

- Surface release with soil or gravel covering

- Surface release from aerial dispersion

The Phase I sampling locations are identified in Table A.1-12. Additional target populations may also be sampled during Phase I, as deemed most efficient and appropriate by the Site Supervisor. While these samples may not directly support Phase I decision making, they will be used if a CAS is elevated to Phase II. 
Table A.1-8

Proposed SVOCs for Analyses

\begin{tabular}{|l|l|l|}
\hline 1,2,4-Trichlorobenzene & Acenaphthene & Di-n-octyl Phthalate \\
1,2-Dichlorobenzene $e^{a}$ & Acenaphthylene & Fluoranthene \\
1,3-Dichlorobenzene & Fluorene \\
1,4-Dichlorobenzene & Aniline & Hexachlorobenzene \\
2,4,5-Trichlorophenol & Anthracene & Hexachlorobutadiene \\
2,4,6-Trichlorophenol & Benzo(a)anthracene & Hexachlorocyclopentadiene \\
2,4-Dichlorophenol & Benzo(a)pyrene & Hexachloroethane \\
2,4-Dimethylphenol & Benzo(b)fluoranthene & Indeno(1,2,3-cd)pyrene \\
2,4-Dinitrophenol & Benzo(g,h,i)perylene & Isophorone \\
2,4-Dinitrotoluene & Benzo(k)fluoranthene & Naphthalene \\
2,6-Dinitrotoluene & Benzoic Acid & Nitrobenzene \\
2-Chloronaphthalene & Benzyl Alcohol & N-Nitroso-di-n-propylamine \\
2-Chlorophenol & Bis(2-chloroethoxy) methane & N-Nitrosodimethylamine \\
2-Methylphenol & Bis(2-chloroethyl)ether & N-Nitrosodiphenylamine \\
2-Nitroaniline & Bis(2-chloroisopropyl)ether & Pentachlorophenol \\
3,3'-Dichlorobenzidine & Bis(2-ethylhexyl) phthalate & Phenanthrene \\
4-Bromophenyl phenyl ether & Butyl benzyl phthalate & Phenol \\
4-Chloroaniline & Carbazole & Pyrene \\
4-Methylphenol & Chrysene & Pyridine \\
4-Nitrophenol & Dibenzo(a,h)anthracene & CAS 23-17-01 \\
& Dibenzofuran & Antifreeze as Ethylene glycol \\
\hline
\end{tabular}

${ }^{a}$ May be reported with VOC.

${ }^{b}$ Analyzed by modified SW8015B.

\section{A.1.4.2 Identify the Spatial and Temporal Boundaries}

The spatial boundaries that apply to each CAS in Phase I are the sample locations selected for Phase I.

Temporal boundaries are those time constraints set up by weather conditions and project schedules. Significant temporal constraints due to weather conditions are not expected. Moist weather may place constraints on sampling and field screening contaminated soils because of the attenuating effect of moisture in samples (e.g., alpha-emitting radionuclides). There are no time constraints on collecting samples as environmental conditions at all sites will not significantly change in the near future and conditions would have stabilized over the years since the sites were last used.

\section{A.1.4.3 Identify Practical Constraints}

The NTS-controlled activities may affect ability to characterize these sites, especially at CAS 05-19-01 which is near the Spill Test Facility and CAS 23-17-01 where material is stored on the 
Table A.1-9

\section{Proposed Herbicides and Pesticides for Analyses}

\begin{tabular}{|l|l|}
\hline \multicolumn{1}{|c|}{ Herbicides } & \multicolumn{1}{|c|}{ Pesticides } \\
\hline \hline $2,4,5-T$ & 4,4 '-DDD \\
$2,4,5-T P($ Silvex $)$ & $4,4 '$-DDE \\
$2,4-D$ & $4,4 '$-DDT \\
$2,4-D B$ & Aldrin \\
Dalapon & Alpha-BHC \\
Dicamba & Alpha-chlordane \\
Dinoseb & Beta-BHC \\
MCPA & Delta-BHC \\
MCPP & Dieldrin \\
& Endosulfan I \\
& Endosulfan II \\
& Endosulfan Sulfate \\
& Endrin \\
& Endrin Aldehyde \\
& Endrin Ketone \\
& Gamma-BHC (lindane) \\
& Gamma-chlordane \\
& Heptachlor \\
& Heptachior epoxide \\
& Methoxychlor \\
& Toxaphene \\
\hline
\end{tabular}

${ }^{a}$ Included in the Endrin PRG when data is reviewed.

gravel above the CAS. Underground utilities may exist at some of the sites, which may limit intrusive sampling locations. Table A.1-13 indicates other practical constraints that may be encountered at each CAS.

\section{A.1.4.4 Define the Scale of Decision Making}

The scale of decision making in Phase I is defined as each CAS.

\section{A.1.5 Step 5 - Develop a Decision Rule}

This step integrates outputs from the previous step with the inputs developed in this step into a decision rule ("If..., then...") statement. This rule describes the conditions under which possible alternative actions would be chosen. 
Table A.1-10

Proposed Explosives, PAH, PCB, and Pyrolytic Oil Compounds for Analyses

\begin{tabular}{|c|c|c|c|}
\hline Explosives & PAH & PCB & Pyrolytic Oil \\
\hline $\begin{array}{l}\text { 1,3,5-Trinitrobenzene } \\
\text { 1,3-Dinitrobenzene } \\
\text { 2,4,6-Trinitrotoluene } \\
\text { 2,4-Dinitrotoluene } \\
\text { 2,6-Dinitrotoluene } \\
\text { 2-Nitrotoluene } \\
\text { 3-Nitrotoluene } \\
\text { 4-Nitrotoluene } \\
\text { HMX } \\
\text { Nitrobenzene } \\
\text { RDX } \\
\text { Tetryl }\end{array}$ & $\begin{array}{l}\text { SVOCs } \\
\text { 3,3'-Dichlorobenzidine } \\
\text { Acenaphthene } \\
\text { Acenaphthylene } \\
\text { Anthracene } \\
\text { Benzo(a)anthracene } \\
\text { Benzo(a)pyrene } \\
\text { Benzo(b)fluoranthene } \\
\text { Benzo(g,h,i)perylene } \\
\text { Benzo(k)fluoranthene } \\
\text { Chrysene } \\
\text { Dibenzo(a,h)anthracene } \\
\text { Dibenzofuran } \\
\text { Fluoranthene } \\
\text { Fluorene } \\
\text { Indene(1,2,3-cd)pyrene } \\
\text { Naphthalene } \\
\text { Phenanthrene } \\
\text { Pyrene }\end{array}$ & $\begin{array}{l}\text { Aroclor-1016 } \\
\text { Aroclor-1221 } \\
\text { Aroclor-1232 } \\
\text { Aroclor- } 1242 \\
\text { Aroclor-1248 } \\
\text { Aroclor-1254 } \\
\text { Aroclor-1260 }\end{array}$ & $\begin{array}{l}\text { VOCs } \\
\text { Benzene } \\
\text { Ethylbenzene } \\
\text { Toluene } \\
\text { Xylene } \\
\text { SVOCs } \\
\text { 1,2,4-Trimethylbenzene } \\
\text { 1,3,5-Trimethylbenzene } \\
\text { 2-Chlorotoluene } \\
\text { Acenaphthene } \\
\text { Acenaphthylene } \\
\text { Anthracene } \\
\text { Bromobenzene } \\
\text { Isopropylbenzene } \\
\text { Naphthalene } \\
\mathrm{N} \text {-butylbenzene } \\
\mathrm{N}-\mathrm{Nitroso} \text {-di-n-propylamine } \\
\mathrm{N}-\mathrm{Nitrosodiphenylamine} \\
\mathrm{N}-\mathrm{Propylbenzene} \\
\text { sec-Butylbenzene } \\
\text { tert-Butylbenzene } \\
\text { PAH } \\
\text { PAH list per this table. } \\
\text { TPH } \\
\text { Diesel range }\left(\mathrm{C}_{10}-\mathrm{C}_{38}\right) \\
\text { Gasoline range }\left(\mathrm{C}_{6}-\mathrm{C}_{10}\right)\end{array}$ \\
\hline
\end{tabular}

\section{A.1.5.1 Specify the Population Parameter}

The population parameter is the maximum observed concentration of each COC within the target population. For radiological surveys, the maximum observed concentration of each $\mathrm{COC}$ will be the population parameter. If sampling is performed to support survey results, the maximum observed concentration of each $\mathrm{COC}$ will be the population parameter. Radionuclide concentrations detected in samples will supersede radiological survey data.

\section{A.1.5.2 Choose an Action Level}

Action levels are the indicators defined in Section A.1.3.2. 
Table A.1-11

CSMs and Their Applicable CASs Utilized in Determining Target Populations

\begin{tabular}{|c|c|c|c|c|c|c|c|c|c|c|}
\hline & CSMs & 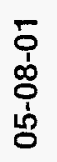 & $\begin{array}{l}\text { ô } \\
0 \\
0 \\
0 \\
0 \\
1 \\
0\end{array}$ & $\frac{\substack{0 \\
\stackrel{1}{1}}}{\frac{1}{8}}$ & $\frac{5}{\grave{o}}$ & 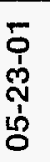 & 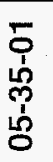 & 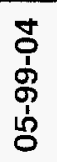 & 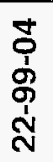 & 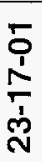 \\
\hline & Surface debris & $x$ & $x$ & $x$ & $x$ & $x$ & $x$ & $x$ & & \\
\hline & $\begin{array}{l}\text { Surface release (some } \\
\text { releases may have been fully } \\
\text { or partially removed) }\end{array}$ & $x$ & $x$ & $\mathrm{x}$ & $x$ & & $x$ & & $x$ & $x$ \\
\hline $\begin{array}{l}\text { Surface } \\
\text { Material }\end{array}$ & Surface refuse burning & & & & $x$ & & $x$ & $x$ & & \\
\hline & $\begin{array}{l}\text { Surface release with soil or } \\
\text { gravel covering }\end{array}$ & & & $x$ & & & $x$ & & & $x$ \\
\hline & $\begin{array}{l}\text { Surface release from aerial } \\
\text { dispersion }\end{array}$ & $x$ & & & & $x$ & & & & \\
\hline Buried D & & $x$ & & $\mathrm{x}$ & $x$ & & & & & $x$ \\
\hline Internal s & ucture & & & & & $x$ & & & & \\
\hline
\end{tabular}

$X$ - The CSM applies to this CAS.

\section{A.1.5.3 Measurement and Analysis Methods}

Radiological surveys were used to identify sampling locations for Phase I at select CASs.

The analyses identified in Section A.1.3.3 for each CAS will be used to identify the presence and location of COCs in Phase I. Indicators (e.g., field conditions, process knowledge) may also be used to identify the presence and location of COCs in Phase I.

The measurement and analysis methods in the Industrial Sites QAPP are capable of achieving the expected range of values to resolve the Phase I Decision. The detection limit of the measurement method to be used is less than the PAL for each COPC unless specified otherwise in the CAIP.

\section{A.1.5.4 Decision Rule}

If the concentration of any COPC in a target population exceeds the PAL for that COPC, then that COPC is identified as a COC and Phase II will be conducted. If the Site Supervisor determines that sufficient indicators are present, then Phase I can be terminated and Phase II initiated. If the COPC concentration is less than the PAL, then the decision will be no further action. 
Table A.1-12

Target Populations and Associated Sampling Locations for Each CAS

\begin{tabular}{|c|c|c|}
\hline CAS & COC Concentrations in the Following & Depth \\
\hline $05-08-01$ & $\begin{array}{l}\text { One biased sample from each detonation pit. One biased sample from each trench. } \\
\text { One biased sample will be collected between the detonation pits based upon } \\
\text { radiological survey results. } \\
\text { One trench will be excavated across the north-south gravel/rock area to confirm no } \\
\text { buried debris requiring sampling is present. }\end{array}$ & 0 to $1 \mathrm{ft}$ \\
\hline $05-08-02$ & $\begin{array}{l}\text { Five biased samples, one from the drum, one from below the overflow pipe, one at the } \\
\text { low point of the smaller evaporation area, and two at the low points of the larger } \\
\text { evaporation area. } \\
\text { One biased sample will be collected from each of three locations where oil/fuel filters } \\
\text { are located. }\end{array}$ & $\begin{array}{l}0 \text { to } 1 \mathrm{ft} \text {, } \\
3 \text { to } 4 \mathrm{ft} \\
0 \text { to } 1 \mathrm{ft}\end{array}$ \\
\hline $05-17-01$ & $\begin{array}{l}\text { One biased sample from a stain area within each of four quadrants. One biased } \\
\text { sample at the concave portion of the mound. } \\
\text { Additionally, a trench will be made through the soil mound to confirm no buried debris } \\
\text { requiring sampling is present. }\end{array}$ & 0 to $1 \mathrm{ft}$ \\
\hline $\begin{array}{l}\text { 05-19-01, } \\
\text { Eastern Area }\end{array}$ & One biased sample from below the debris pile. & 0 to $1 \mathrm{ft}$ \\
\hline $\begin{array}{l}\text { 05-19-01, } \\
\text { Middle Area }\end{array}$ & $\begin{array}{l}\text { Three biased locations at the outside edges of the buried debris boundary. } \\
\text { One biased sample from below the debris pile. }\end{array}$ & $\begin{array}{l}0 \text { to } 1 \mathrm{ft} \\
4 \text { to } 5 \mathrm{ft} \\
0 \text { to } 1 \mathrm{ft}\end{array}$ \\
\hline $\begin{array}{l}05-19-01 \\
\text { Western Area }\end{array}$ & $\begin{array}{l}\text { One biased sample collected from the burn area. One biased sample from below the } \\
\text { debris pile. }\end{array}$ & 0 to $1 \mathrm{ft}$ \\
\hline $\begin{array}{l}\text { 05-23-01, } \\
\text { Structure }\end{array}$ & $\begin{array}{l}\text { Two biased locations will be sampled on the top of the roof based upon radiological } \\
\text { survey results. } \\
\text { The determination of COCs present, within the Gravel Gertie, will be based upon } \\
\text { process knowledge. }\end{array}$ & $\begin{array}{l}0 \text { to } 1 \mathrm{ft} \text { into } \\
\text { roof }\end{array}$ \\
\hline $\begin{array}{l}\text { 05-23-01, } \\
\text { excluding } \\
\text { structure }\end{array}$ & $\begin{array}{l}\text { One biased location in front of door. Two biased locations will be sampled based upon } \\
\text { radiological survey results. }\end{array}$ & 0 to $1 \mathrm{ft}$ \\
\hline $05-35-01$ & $\begin{array}{l}\text { One biased sample from each quadrant designated by north-south and east-west } \\
\text { intersecting lines. The burn stains in the road will be used as the biasing locations in } \\
\text { the applicable quadrants. }\end{array}$ & $\begin{array}{l}0 \text { to } 1 \mathrm{ft} \\
3 \text { to } 4 \mathrm{ft}\end{array}$ \\
\hline $05-99-04$ & One biased sample from each of the three burn areas. & 0 to $1 \mathrm{ft}$ \\
\hline $22-99-04$ & One biased sample from the center of the sandbags. & 0 to $1 \mathrm{ft}$ \\
\hline $23-17-01$ & $\begin{array}{l}\text { Eight systematic grid locations. } \\
\text { Samples will be collected adjacent to the outside edge of the buried debris. }\end{array}$ & $\begin{array}{l}0 \text { to } 1 \mathrm{ft} \\
3 \text { to } 4 \mathrm{ft} \\
4 \text { to } 5 \mathrm{ft} \\
9 \text { to } 10 \mathrm{ft} \\
14 \text { to } 15 \mathrm{ft}\end{array}$ \\
\hline
\end{tabular}

${ }_{b}^{\mathrm{a}}$ The sampling locations are tentative and may be altered based upon additional information.

${ }^{\mathrm{b}}$ Additional information regarding sampling is detailed in Section A.1.7.2. 
Table A.1-13

Practical Constraints Identified for CAU 140

\begin{tabular}{|c|c|c|c|c|c|}
\hline CAS & $\begin{array}{l}\text { Utilities Likely to } \\
\text { be Encountered }\end{array}$ & $\begin{array}{c}\text { Topography/Site } \\
\text { Conditions Likely } \\
\text { to Effect Planned } \\
\text { Activities }\end{array}$ & $\begin{array}{c}\text { Structures } \\
\text { (e.g., materials) } \\
\text { Likely to Effect } \\
\text { Planned Activities }\end{array}$ & $\begin{array}{l}\text { Area Subject to } \\
\text { Access } \\
\text { Restrictions }^{b}\end{array}$ & $\begin{array}{l}\text { Confined } \\
\text { Space, } \\
\text { Structural } \\
\text { Integrity } \\
\text { Issues }\end{array}$ \\
\hline $05-08-01$ & None known & No & No & Yes & No \\
\hline $05-08-02$ & None known & No & No & No & No \\
\hline $05-17-01$ & None known & No & No & No & No \\
\hline 05-19-01 & None known & No & No & Yes & No \\
\hline $05-23-01$ & Historical & No & Yes & No & Yes \\
\hline $05-35-01$ & None known & No & No & Yes & No \\
\hline $05-99-04$ & None known & No & No & No & No \\
\hline $22-99-04$ & None known & No & No & Yes & No \\
\hline $23-17-01$ & None known & No & Yes & Yes & No \\
\hline
\end{tabular}

Source: Site visits

a Utility constraints are subject to change as detailed information is collected prior to commencement of investigation activities and will be appropriately documented. All CASs will be surveyed for utilities prior to field activities in accordance with the SSHASP.

${ }^{b}$ Access restrictions include both scheduling conflicts on the NTS with other entities and areas posted as contamination areas requiring appropriate work controls, and areas requiring authorized access.

\section{A.1.6 Step 6 - Specify the Tolerable Limits on Decision Errors}

The sampling approach for Phase I relies on biased sampling locations. Only validated analytical results (quantitative data) will be used to determine if COCs are present, unless otherwise stated. The baseline condition (i.e., null hypothesis) and alternative condition for Phase I are:

- Baseline condition - A COC is present

- Alternative condition - A COC is not present

Decisions and/or criteria have an alpha (false negative) or beta (false positive) error associated with their determination (discussed in the following subsections). Since quantitative data are individually compared to action levels, statistical evaluations of the data such as averages or confidence intervals are not appropriate. 


\section{A.1.6.1 False Rejection Decision Error}

The false rejection (alpha) decision error would mean deciding that a COC is not present when it is, increasing risk to human health and environment.

A false rejection decision error (where consequences are more severe) is controlled by meeting these criteria: (1) having a high degree of confidence that the sample locations selected will identify COCs if present anywhere within the CAS and (2) having a high degree of confidence that analyses conducted will be sufficient to detect any COCs present in the samples.

To satisfy the first criterion, Phase I data and samples will be collected in areas most likely to be contaminated by any COCs. To accomplish this, the following characteristics are considered:

- Source and location of release

- Chemical nature and fate properties

- Physical transport pathways and properties

- Hydrologic drivers

These characteristics were considered during the development of the CSMs and selection of sampling locations. The biasing factors listed in Section A.1.3.1 will be used to further ensure that these criteria are met.

To satisfy the second criterion, all Phase I samples will be analyzed for the chemical and radiological parameters listed in Section A.1.3.3. Strict adherence to established procedures and QA/QC protocol protects against false negatives.

\section{A.1.6.2 False Acceptance Decision Error}

The false acceptance (beta) decision error would mean deciding that a COC is present when it is not, resulting in increased costs for unnecessary characterization.

The false acceptance decision error is controlled by protecting against false positive analytical results. False positive results are typically attributed to laboratory and/or sampling/handling errors. Quality assurance/quality control samples such as field blanks, trip blanks, laboratory control samples, and method blanks are used to determine if a false positive analytical result may have occurred. Other 
measures include proper decontamination of sampling equipment and using certified clean sample containers to avoid cross contamination.

\section{A.1.6.3 Quality Assurance/Quality Control}

Radiological survey instruments will be calibrated in accordance with manufacturer's instructions and periodic calibrations will be performed in accordance with approved procedures.

Quality control samples will be collected as required by established procedures. The required QC samples include:

- Trip blanks (1 per sample cooler containing VOC environmental samples)

- Equipment blanks (1 per sampling event for each type of decontamination procedure)

- Source blanks (1 per source lot per sampling event)

- Field duplicates (minimum of 1 per matrix per 20 environmental samples)

- Field blanks (minimum of 1 per 20 environmental samples or 1 per sampling day, whichever best exemplifies field conditions)

- Matrix spike/matrix spike duplicate (minimum of 1 per matrix per 20 environmental samples), not needed for some radioanalytical measurements (e.g., gamma spectrometry)

Additional QC samples may be submitted based on site conditions.

Data Quality Indicators of precision, accuracy, comparability, completeness, and representativeness are defined in the Industrial Sites QAPP (NNSA/NV, 2002). In addition, sensitivity has been included as a DQI for laboratory analyses. Site-specific DQIs are discussed in more detail in Section 6.0 of the CAIP.

\section{A.1.7 Step 7 - Optimize the Design for Obtaining Data}

Intrusive sampling will be conducted at CAU 140 during Phase I. Sampling locations were determined based on the results of surveys and other biasing factors listed in Section A.1.3.1. The Site Supervisor has the discretion to modify the biased locations, but only if the modified locations 
meet the decision needs and criteria stipulated in Section A.1.3. The following sections provide general Phase I activities.

\section{A.1.7.1 Radiological Survey Methodologies and Instruments}

Radiological surveys were conducted at CASs 05-08-01, 05-19-01, and 05-23-01 to determine the presence of surficial gamma and high energy beta-emitting radiological contaminants exceeding background at the 95 percent confidence level.

A combination of walk-over surveys using handheld instruments and drive-over surveys using a vehicle-mounted detector were performed on those portions of the CAU 140 investigation area based on CAS accessibility and resulting in a nearly 100 percent survey. The TSA-PRM-470B was used as the handheld instrument. The DLAPS and TSA-VMR-3 were used as the vehicle-mounted instruments. Additional equipment and software used in the radiological data collection and processing included a Trimble ${ }^{\mathrm{TM}}$ GPS receiver, laptop computer used to log and process the walk-over and drive-over radiological data, and Surfer ${ }^{\mathrm{TM}}$ to plot the data.

\section{A.1.7.2 Intrusive Investigation}

Intrusive investigations will be conducted at each of the CAU 140 CASs to determine if a COC is present. Samples from each site will be collected from the biased locations identified in Table A.1-13. Biased locations for these activities are determined based on the biasing factors listed in Section A.1.3.1.

Rotary-sonic drilling, hollow-stem auger drilling, direct push, handheld augers, excavation, or other appropriate collection techniques will be used to access sample intervals for laboratory analysis at select locations to determine if a COC is present. Due to the potentially dangerous nature of buried waste (e.g., compressed gas cylinders, medical waste, asbestos), sample locations may be biased adjacent to any buried wastes. Buried waste may be accessed directly based upon the technical judgement of the Site Supervisor.

\section{Sampling at CASs 05-08-01, 05-99-04, and 22-99-04}

Biased sampling locations in these CASs are based upon soil staining, site characteristics, and radiological surveys. Samples from these CASs will be collected in the 0- to 1-ft interval. 


\section{Sampling at CAS 05-08-02}

Biased samples are to be collected at the low point in each of the two depressions which resemble evaporation ponds, at the low point within the ponds. Two sample locations will be collected in the larger of the evaporation ponds. Additional biased samples will be collected from below the "overflow" pipe and from the partially buried drum. If the area resembling an evaporator pond was ever used as an evaporator pond, contaminants may have migrated further in the vertical direction. For this reason, samples from the CAS 05-08-02 evaporator pond will be collected in the 0- to $1-\mathrm{ft}$ and 3- to 4-ft intervals. Additionally, biasing factors will be utilized to identify and collect samples between $1 \mathrm{ft}$ and $3 \mathrm{ft}$, as necessary.

A biased sample will be collected from each of three locations where oil/fuel filters are located. These samples will be collected in the 0 - to 1 - $\mathrm{ft}$ interval.

\section{Sampling at CAS 05-17-01}

A biased sample is to be collected immediately adjacent to the concave portion of the dirt/gravel pile. This is the location where the wood frame structure from the bunker is believed to have been removed. The location for biased samples will be determined by drawing an approximately north-south and east-west line through the CAS. Four samples, one sample from a stained area within each quadrant will be collected. Samples from CAS 05-17-01 will be collected in the 0-to 1-ft interval.

\section{Sampling at CAS 05-19-01}

Biased sampling locations in CAS 05-19-01 are based upon debris locations and radiological surveys. Soil samples collected in the vicinity of the buried debris are expected to be collected at the edge of the buried debris area (i.e., where there is not the risk of disturbing the buried debris). Three samples will be collected adjacent to the outside edge of the buried debris, approximately 120 degrees from each other. Samples will be collected in the 0 - to 1 - $\mathrm{ft}$ and 4 - to 5 -ft intervals.

Should buried debris be identified at other CASs, the sampling strategy stated above will be utilized for those areas where buried debris is located. 


\section{Sampling at CAS 05-23-01}

Two biased samples will be collected on the top of the roof of Gravel Gertie in the 0- to 1-ft interval to determine if surface contamination is present. These locations were selected based upon the radiological survey (Alderson, 2002).

The determination as to whether COCs are present within the Gravel Gertie structure will be based on a study of operational activities. The results of the study will be presented in the CADD.

Samples from CAS 23-17-01, exterior to the Gravel Gertie structure, will be collected from locations identified by radiological surveys. Those locations that are determined to have radioactive contamination significantly exceeding background at the 95 percent confidence level will be evaluated for sampling. Two sample locations were identified from the radiological survey. Additionally, one sample will be collected in front of the entrance (based upon the testing map generated after detonation testing [Sandia Corporation, 1964]). Samples from CAS 23-17-01, exterior to the Gravel Gertie, will be collected in the 0 - to 1 - $\mathrm{ft}$ interval.

\section{Sampling at CAS 05-35-01}

The location for samples will be determined by drawing an approximately north-south and east-west line through the CAS. One sample will then be collected from each of the grids based on the presence of biasing factors. When biasing criteria are absent, samples may be omitted from the respective grid. The burn stain areas in the dirt road will be used as the biased sample for the quadrant they are in. This site has been graded, and the top portion of the soil disturbed. For this reason, samples from CAS 05-35-01 will be collected in the 0- to 1-ft and 3- to 4-ft intervals. Additionally, biasing factors will be utilized to identify and collect samples between $1 \mathrm{ft}$ and $3 \mathrm{ft}$, as necessary.

\section{Sampling at CAS 23-17-01}

The surface storage area of CAS 23-17-01 is sampled using a systematic grid. The location for the systematic grid samples will be determined by griding the site into 8 sections. One sample location will then be identified in each of the grids. Biasing factors will be used to select the locations, if available. Information obtained during the PA indicates that spills had occurred and soil was removed. For this reason, samples from CAS 23-17-01 will be collected in the 0 - to 1 -ft and 3- to 4-ft 
intervals. Dependent upon the depth of the landfill, the planned 3- to 4-ft interval may be collected at a shallower depth. Additionally, biasing factors will be utilized to identify and collect samples between $1 \mathrm{ft}$ and $3 \mathrm{ft}$, as necessary. Measurements for sample depth will begin after the gravel from the parking/storage area has been moved aside.

Sample locations and intervals have been selected based on the results of the EM31 and resistivity geophysical surveys. The bottom depth of the buried debris is expected to be 12- to 14-ft bgs. The boundaries of buried metallic debris and conductivity anomalies are shown in Figure 4-10. Samples will be collected at the 4- to 5-ft, 9- to $10-\mathrm{ft}$, and 14- to $15-\mathrm{ft}$ intervals for locations placed adjacent to buried metallic debris.

For the elevated conductivity (non-metallic) area, two boreholes will be drilled to a depth of $14 \mathrm{ft}$ to determine if biasing factors (e.g., buried debris) are present. If biasing factors are present, a 1-ft sample interval will be collected at the deepest biasing factor (e.g., buried debris)/soil interface and from select locations within the borehole based upon the technical judgement of the Site Supervisor. Buried debris will not be sampled for analysis. 


\section{A.2.0 Seven-Step DQO Process for Phase II Investigations}

This section discusses the DQO process for Phase II for any CAS that requires further assessment based on Phase I results. If COCs are identified, the CAS will proceed to Phase II.

\section{A.2.1 Step 1 - State the Problem}

Refer to Section A.1.1 for information regarding Step 1.

\section{A.2.2 Step 2 - Identify the Decision}

This step develops a decision statement and defines alternative actions.

\section{A.2.2.1 Develop a Decision Statement}

The decision statement for Phase II is "Determine the lateral and vertical extent of a COC."

\section{A.2.2.2 Alternative Actions to the Decision}

If extent of a COC is defined in both the lateral and vertical directions, further assessment of the CAS is not required. If extent is not defined, reevaluate site conditions and collect additional samples.

\section{A.2.3 Step 3 - Identify the Inputs to the Decision}

This step identifies the information needed, determines sources for information, determines the basis for establishing the action level, and identifies sampling and analysis methods that can meet the data requirements.

\section{A.2.3.1 Information Needs and Information Sources}

In order to determine the extent of a COC, samples must be collected at locations to bound the lateral and vertical extent of COCs. The data required to satisfy the information need for each COC is a sample result that is below the PAL. Step-out locations, as defined in Section A.2.7, will be selected. 
Samples will only be analyzed for those parameters that exceeded PALs (i.e., COCs) in prior samples. Biasing factors to support these information needs may include:

- Geophysical and/or radiological surveys

- Documented process knowledge on source and location of release

- Field observations

- Field-screening results

- Historical sample results

- Experience and data from investigations of similar sites

- Professional judgement

- Phase I and prior Phase II sample results

Table A.2-1 lists the information inputs, the source of information for each input, and the proposed methods to collect the data. Additional information is provided in Section A.1.3.1.

Table A.2-1

Information Needed to Resolve the Phase II Decision

\begin{tabular}{|l|l|l|l|}
\hline \multicolumn{1}{|c|}{ Information Need } & Information Source & Collection Method & Data Type/Metric \\
\hline \multicolumn{3}{|c|}{ Decision: Determine the extent of a COC } \\
\hline $\begin{array}{l}\text { Identification of } \\
\text { applicable Phase II } \\
\text { contaminants }\end{array}$ & $\begin{array}{l}\text { Data packages of prior } \\
\text { samples }\end{array}$ & $\begin{array}{l}\text { Review analytical results } \\
\text { to select Phase II COCs. }\end{array}$ & $\begin{array}{l}\text { Quantitative - Only COCs } \\
\text { previously identified will } \\
\text { be analyzed in future } \\
\text { sampling events. }\end{array}$ \\
\hline \multirow{3}{*}{ Extent of Contamination } & Field observations & $\begin{array}{l}\text { Document field } \\
\text { observations. }\end{array}$ & $\begin{array}{l}\text { Qualitative - CSM has not } \\
\text { been shown to be } \\
\text { inaccurate. }\end{array}$ \\
\cline { 2 - 5 } & Field screening & $\begin{array}{l}\text { Conduct field screening } \\
\text { with appropriate } \\
\text { instrumentation. }\end{array}$ & $\begin{array}{l}\text { Semiquantitative - FSRs } \\
\text { will be compared to FSLs. }\end{array}$ \\
\cline { 2 - 5 } & Phase II analytical results & $\begin{array}{l}\text { Appropriate sampling } \\
\text { techniques and approved } \\
\text { analytical methods will be } \\
\text { used to bound COCs. }\end{array}$ & $\begin{array}{l}\text { Quantitative - Validated } \\
\text { analytical results will be } \\
\text { compared to PALs to } \\
\text { determine COC extent. }\end{array}$ \\
\hline
\end{tabular}

\section{A.2.3.2 Determine the Basis for Preliminary Action Levels}

Laboratory analytical results will be compared to the applicable PALs presented in Section A.1.3.2 to determine if COPCs are present at levels that may pose an unacceptable risk to human health and/or the environment (i.e., COCs). 


\section{A.2.3.3 Potential Sampling Techniques and Appropriate Analytical Methods}

Section A.1.3.3 provides details regarding potential sampling techniques. To assure that laboratory analyses are sufficient to detect contamination in samples, chemical and radiological parameters will be selected based on Phase I analytical data. Only those COCs identified will be analyzed during Phase II. This parameter selection process will be applied independently to each CAS as discussed in Section A.2.4.4, "Scale of Decision Making."

\section{A.2.4 Step 4 - Define the Boundaries of the Study}

The purpose of this step is to define the target population of interest, specify the spatial and temporal features of that population that are pertinent for decision making, determine practical constraints on data collection, and define the scale of decision making relevant to target populations.

\section{A.2.4.1 Define the Target Population}

The target populations for each CAS are COC concentrations in soil at step-out locations (lateral and/or vertical) at each CAS.

Phase II target populations will be limited to COCs. These target populations represent locations within the system that, when sampled, will provide sufficient data to address data needs discussed in Section A.2.2.

\section{A.2.4.2 Determine the Spatial and Temporal Boundaries}

The spatial boundaries that apply to each CAS for Phase II are shown in Table A.2-2. In general, geographic boundaries are defined by the impacted soil. Intrusive activities are not intended to extend into CASs not in CAU 140. Temporal boundaries are defined in Section A.1.4.2.

\section{A.2.4.3 Identify Practical Constraints}

Practical constraints are listed in Section A.1.4.3.

\section{A.2.4.4 Define the Scale of Decision Making}

The scale of decision making is defined as a contiguous area contaminated with any COC at each CAS. 
Table A.2-2

Spatial Boundaries for Phase II Sites

\begin{tabular}{|c|c|c|}
\hline \multirow{2}{*}{ CAS } & \multicolumn{2}{|l|}{ Spatial Boundary } \\
\hline & Horizontal & Vertical \\
\hline $\begin{array}{l}05-08-01 \\
\text { Detonation Pits }\end{array}$ & $100-\mathrm{ft}$ buffer around the CAS. & $50 \mathrm{ft}$ bgs \\
\hline $\begin{array}{l}05-08-02 \\
\text { Debris Pits }\end{array}$ & 100-ft buffer around the CAS. & $50 \mathrm{ft}$ bgs \\
\hline $\begin{array}{l}05-17-01 \\
\text { Hazardous Waste } \\
\text { Accumulation Site }\end{array}$ & 100-ft buffer around the CAS. & $50 \mathrm{ft} \mathrm{bgs}$ \\
\hline $\begin{array}{l}05-19-01 \\
\text { Waste Disposal Site }\end{array}$ & 100-ft buffer around the CAS. & $50 \mathrm{ft}$ bgs \\
\hline $\begin{array}{l}05-23-01 \\
\text { Gravel Gertie }\end{array}$ & $\begin{array}{l}100-\mathrm{ft} \text { buffer around the CAS. } 1,800-\mathrm{ft} \text { buffer for the } \\
\text { radiological survey drive-over. }\end{array}$ & $50 \mathrm{ft}$ bgs \\
\hline $\begin{array}{l}05-35-01 \\
\text { Burn Pit }\end{array}$ & 100-ft buffer around the CAS. & $50 \mathrm{ft}$ bgs \\
\hline $\begin{array}{l}05-99-04 \\
\text { Burn Pit }\end{array}$ & 100-ft buffer around the CAS. & $50 \mathrm{ft}$ bgs \\
\hline $\begin{array}{l}22-99-04 \\
\text { Radioactive Waste } \\
\text { Dump }\end{array}$ & 100-ft buffer around the CAS. & $50 \mathrm{ft}$ bgs \\
\hline $\begin{array}{l}23-17-01 \\
\text { Hazardous Waste } \\
\text { Storage Area }\end{array}$ & $\begin{array}{l}\text { 100-ft buffer around the CAS. The closed Hazardous Waste } \\
\text { Trenches (CAU 112, CAS 23-21-02) and adjacent landfills } \\
\text { will not be entered. }\end{array}$ & $50 \mathrm{ft} \mathrm{bgs}$ \\
\hline
\end{tabular}

\section{A.2.5 Step 5 - Develop a Decision Rule}

This step integrates outputs from previous steps with the inputs developed in this step into a decision rule ("If....., then....") statement. This rule describes the conditions under which possible alternative actions would be chosen.

\section{A.2.5.1 Specify the Population Parameter}

The population parameter will be the observed concentration of each COC contained in any sample.

\section{A.2.5.2 Choose an Action Level}

Action levels were previously defined in Section A.1.3.2. 


\section{A.2.5.3 Measurement and Analysis Methods}

The measurement and analysis methods in the Industrial Sites QAPP (NNSA/NV, 2002) are capable of achieving the expected range of values. The detection limit of the measurement method to be used is less than the PAL for each COPC, unless specified otherwise in the CAIP. See Section A.1.3.3 for additional details.

\section{A.2.5.4 Decision Rule}

If the observed concentration of any COPC in a sample exceeds the PALs, then additional samples will be collected to define extent. If the observed concentration is less than PALs, then the decision will be that the extent of contamination has been defined in the lateral and/or vertical direction.

If contamination is inconsistent with the CSM or extends beyond the spatial boundaries identified in Table A.2-2, then work will be suspended and the investigation strategy will be reevaluated. If contamination is consistent with the CSM and is within spatial boundaries, then the decision will be to continue sampling to define the extent.

\section{A.2.6 Step 6 - Specify Tolerable Limits on Decision Errors}

The sampling approach for Phase II relies upon biased samples; therefore, statistical analysis is not appropriate. Only validated analytical results (quantitative) will be used to determine COC extent.

The baseline condition (i.e., null hypothesis) and alternative condition for Phase II are as follows:

- Baseline condition - The extent of a COC has not been defined.

- Alternative condition - Extent of a COC has been defined.

\section{A.2.6.1 False Rejection Decision Error}

The false rejection (alpha) decision error would mean accepting that the extent of a COC has been defined when it has not, increasing risk to human health and environment.

A false rejection decision error (where consequences are more severe) is controlled by meeting these criteria: (1) having a high degree of confidence that the sample locations selected will identify the extent of COCs and (2) having a high degree of confidence that analyses conducted will be sufficient to detect any COCs present in the samples. 
To satisfy that the first criterion is met, the Phase II data collection will sample areas that represent the lateral and vertical extent of contamination by considering the following characteristics:

- Source and location of release

- Chemical nature and fate properties

- Physical transport pathways and properties

- Hydrologic drivers

These characteristics were considered during the development of the CSMs. The biasing factors listed in Section A.2.3.1 will be used to further ensure that the first criterion is met.

To meet the second criterion, Phase II samples will be analyzed for those chemical and radiological parameters that were identified as COCs in Phase I samples. Strict adherence to established procedures and $\mathrm{QA} / \mathrm{QC}$ protocol protects against false negatives.

\section{A.2.6.2 False Acceptance Decision Error}

The false acceptance (beta) decision error would mean accepting that the extent of a COC has not been defined when it really has, resulting in increased costs for unnecessary corrective action.

The false acceptance decision error is controlled by protecting against false positive analytical results. False positive results are typically attributed to laboratory errors and sampling/handling errors. Quality assurance/quality control samples such as field blanks, trip blanks, laboratory control samples, and method blanks are used to determine if a false positive analytical result may have occurred. Other measures include proper decontamination of sampling equipment and using certified clean sample containers to avoid cross contamination.

\section{A.2.6.3 Quality Assurance/Quality Control}

Quality assurance/quality control protocols are presented in Section A.1.6.3.

\section{A.2.7 Step 7 - Optimize the Design for Obtaining Data}

Biased sampling for laboratory analysis will be conducted at CAU 140 during Phase II. Biased sampling locations will be determined prior to the investigation, based on process knowledge and analytical results from Phase I. As field data are generated (e.g., radiological surveys, field-screening, and Phase I analytical results), the Site Supervisor has the discretion to modify these 
locations but only if the modified locations meet the decision needs and criteria stipulated in Section A.2.3.

Rotary-sonic drilling, hollow-stem auger drilling, direct push, handheld augers, excavation, or other appropriate collection techniques will be used to access sample intervals for laboratory analysis at select locations to determine if a COC is present. Due to the potentially dangerous nature of buried waste (e.g., compressed gas cylinders, medical waste, asbestos), sample locations may be biased adjacent to any buried wastes. Buried waste may be accessed directly at the discretion of the Site Supervisor.

Step-out sample locations will be selected approximately $15 \mathrm{ft}$ from outer boundary sample locations where COCs were detected. If biasing factors indicate COCs extend beyond the proposed Phase II sample locations, further step-out locations may be necessary. At each Phase II surface area location, soil samples will be collected at the depth(s) and at $2 \mathrm{ft}$ below the lowest depth where COCs were encountered. At each Phase II subsurface area location, soil samples will be collected at the depth(s) and at $4 \mathrm{ft}$ below the lowest depth where COCs were encountered. When indicators or biasing factors indicate that the step-out sample results may exceed the PAL, then an additional step-out distance may be used. If the step-out locations from different original locations approach each other, then the Site Supervisor may consider this as one area, and collect samples only in the outward directions.

For the Gravel Gertie structure roof samples, the step-out locations will be selected which are adjacent to the exterior of the Gravel Gertie, in the 0 - to 1 - $\mathrm{ft}$ interval.

For the elevated conductivity (non-metallic) area in CAS 23-17-01, the lateral Phase II sampling locations will be located adjacent to the edge of the higher conductivity area or as necessary to determine the extent of the landfill cells. If COCs are present, then samples will be collected during the drilling.

In general, samples submitted for laboratory analysis would be those that define the lateral and vertical extent of COCs. Additional samples will be collected to define the extent of COCs, if necessary. 
Adams, S.R., IT Corporation. 2002. Memorandum to D. Wilson (Science Applications International Corporation) entitled, "Chlorine-36 Issues at Corrective Action Unit (CAU) 140," 28 March. Las Vegas, NV.

Alderson, S., IT Corporation. 2002. Memorandum to J. Nicklas (Science Applications International Corporation) entitled, "Radiological Land Area Surveys of Corrective Action Unit (CAU) 140 at The Nevada Test Site," 28 June. Las Vegas, NV.

Bechtel Nevada. 1997. Application for Permit to Operate a Class II Solid Waste Disposal Site at the Nevada Test Site, Area Disposal Site, Rev. 1. Las Vegas, NV.

Black, S. C., and Y. E. Townsend. 1996. U.S. Department of Energy Nevada Operations Office, Environmental Data Report for the Nevada Test Site - 1994, DOE/NV/11718-026, DOE/NV/11432-176. Las Vegas, NV.

BN, see Bechtel Nevada.

California Integrated Waste Management Board. 2001. "Evaluation of Employee Health Risk from Open Tire Burning." As accessed at www.ciwmb.ca.gov/leaadvisory/46/ on 29 September.

CIWMB, see California Integrated Waste Management Board.

DOE/NV, see U.S. Department of Energy, Nevada Operations Office.

EPA, see U.S. Environmental Protection Agency.

McArthur, R.D., and F.L. Miller, Jr. 1989. Off-Site Radiation Exposure Review Project (ORERP), Phase II Soil Program, DOE/NV/10384-23, Publication No. 45064. Las Vegas, NV: Desert Research Institute.

Metcalf, J., Sandia National Laboratories. 2002. Record of telecon with A. Dudley (Science Applications International Corporation) regarding CAU140, CAS 05-23-01, 6 March. Las Vegas, NV: ITLV.

Moore, J., Science Applications International Corporation. 1999. Memorandum to M. Todd (SAIC) entitled, "Background Concentrations for NTS and TTR Soil Samples," 3 February.

Las Vegas, NV: IT Corporation.

NAC, see Nevada Administrative Code. 
National Council on Radiation Protection and Measurements. 1999. Recommended Screening Limits for Contaminated Surface Soil and Review of Factors Relevant to Site-Specific Studies, NCRP Report No. 129. Bethesda, MD.

NBMG, see Nevada Bureau of Mines and Geology.

NCRP, see National Council on Radiation Protection and Measurements.

Nevada Administrative Code. 2002. NAC 445A.2272, "Contamination of Soil: Establishment of Action Levels." Carson City, NV.

Nevada Bureau of Mines and Geology. 1998. Mineral and Energy Resource Assessment of the Nellis Air Force Range, Open-File Report 98-1. Reno, NV.

NNSA/NV, see U.S. Department of Energy, National Nuclear Security Administration Nevada Operations Office.

SAIC, see Science Applications International Corporation.

Sandia Corporation. 1964. Measurements from Gravel Gertie Tests, July, SC-R-64-127. Albuquerque, NM.

Science Applications International Corporation. 2001. Surface Geophysical Survey Report Preliminary Assessment Sites Nevada Test Site, December. Prepared for IT Corporation in Las Vegas, Nevada. Harrisburg, PA.

U.S. Department of Energy, National Nuclear Security Administration Nevada Operations Office. 2002. Industrial Sites Quality Assurance Project Plan, Nevada Test Site, Nevada, Rev. 3, DOE/NV--372. Las Vegas, NV.

U. S. Department of Energy, Nevada Operations Office. 1986. Environmental Assessment for the LGF Spill Test Facility at Frenchman Flat, Nevada Test Site. Las Vegas, NV.

U.S. Department of Energy, Nevada Operations Office. 1997. Annual Report Post-Closure Monitoring and Inspection for the Mercury Landfill Hazardous Waste Trenches for the Period October 1995-October 1996, DOE/NV-11718-092, UC-712, January. Las Vegas, NV.

U.S. Department of Energy, Nevada Operations Office. 1998. Nevada Test Site Resource Management Plan, DOE/NV-518. Las Vegas, NV.

US Ecology and Atlan-Tech. 1992. Environmental Monitoring Report for the Proposed Ward Valley, California, LLRW Facility. Rosewell, GA.

U.S. Environmental Protection Agency. 2000. Region IX Preliminary Remediation Goals (PRGs). Prepared by S.J. Smucker. San Francisco, CA. 
USGS, see U.S. Geological Survey.

U.S. Geological Survey. 1964. Summary of Hydraulic Data, Quality of Water, and Lithologic Log for Army Well 1, Mercury Valley, Nye County, Nevada, Technical Letter NTS-71, 15 January. Prepared by G.L. Meyer, and R.E. Smith. Denver, CO.

U.S. Geological Survey. 1975. Hydrogeologic and Hydrochemical Framework, South-Central Great Basin, Nevada-California, with Special Reference to the Nevada Test Site,

USGS-PP712-C. Prepared by I. J. Winogard and W. Thordarson on behalf of the U.S. Atomic Energy Commission. Denver, CO.

Williams, K., Bechtel Nevada. 1998. Record of meeting with J. Markowsky (Science Applications International Corporation), regarding the Area 23 Hazardous Waste Storage Area, 29 January. Las Vegas, NV. 


\section{APPENDIX B*}

\section{CLOSURE CERTIFICATION}

*Appendix B, Closure Certification, of the standardized outline for a Federal Facility Agreement and Consent Order Closure Report is not applicable to the closure of CAU 140. 
Closure Report - CAU 140

Section: Appendix B

Revision: 0

Date: August 2005

THIS PAGE INTENTIONALLY LEFT BLANK 


\section{APPENDIX C*}

\section{AS-BUILT DOCUMENTATION}

* Appendix C, As-Built Documentation, of the standardized outline for a Federal Facility Agreement and Consent Order Closure Report is not applicable to CAU 140, as no engineered structures were built. 
Closure Report - CAU 140

Section: Appendix C

Revision: 0

Date: August 2005

THIS PAGE INTENTIONALLY LEFT BLANK 


\section{APPENDIX D}

\section{SAMPLE ANALYTICAL RESULTS}


Closure Report - CAU 140

Section: Appendix D

Revision: 0

Date: August 2005

THIS PAGE INTENTIONALLY LEFT BLANK 
Closure Report - CAU 140

Section: Appendix D

Revision: 0

Date: August 2005

THIS PAGE INTENTIONALLY LEFT BLANK 


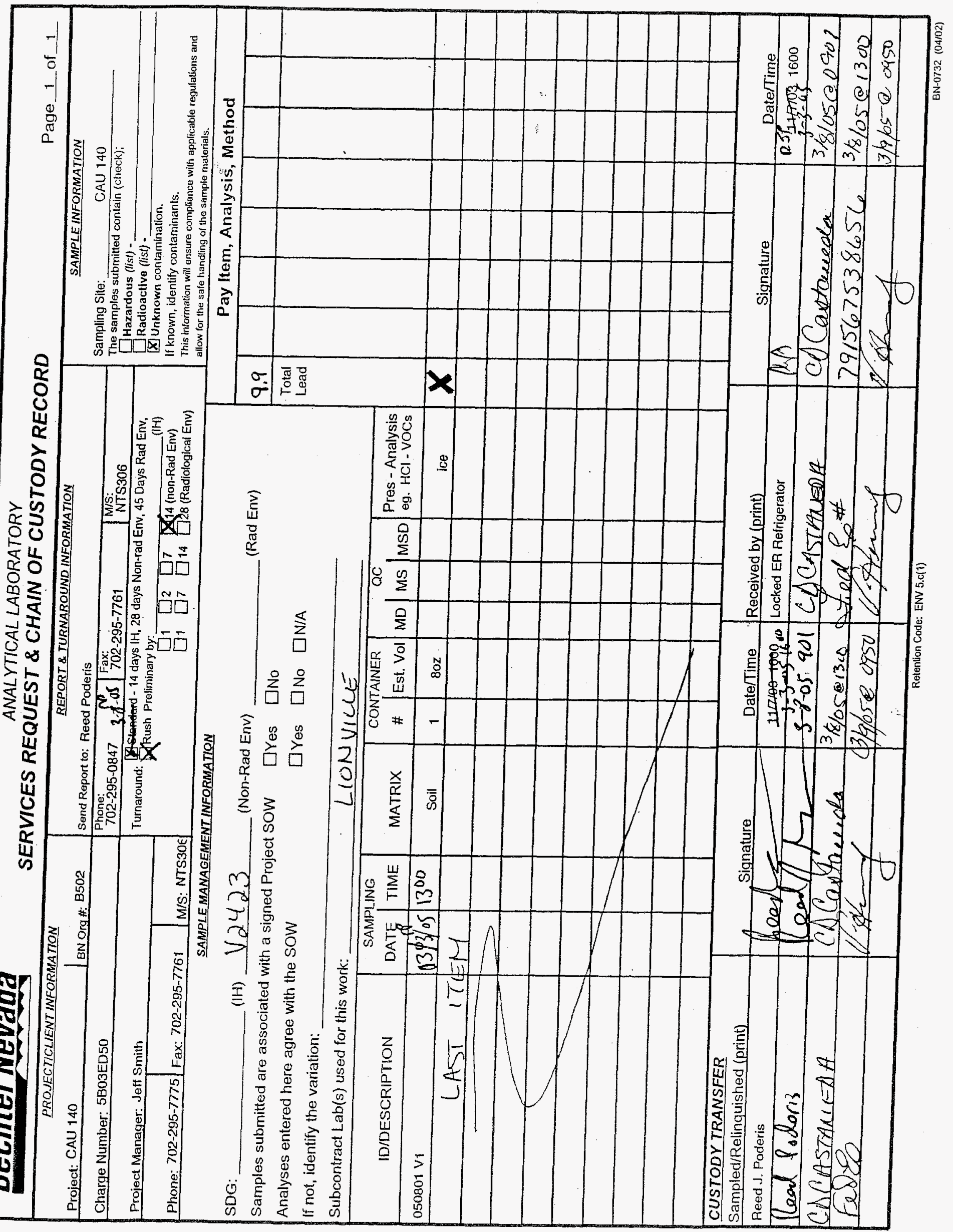




\section{Analytical-Repor}

Client : BECHTEL NEVADA V2423

LVL\#: 0503L945
W.O.\# : 60052-001-001-0001-00

Date Received : 03-09-05

\section{SW846 METALS}

1. This narrative covers the analysis of I soil sample

2. The sample was prepared and analyzed in accordance with SW-846 protocol and reported with a CLP deliverable.

3. ICVs, CCVs, and LCSs stock standards were purchased from Inorganic Ventures Laboratory and High Purity.

4. All analyses were performed within the required holding times.

5. All results presented in this report are derived from samples that met LvLI's sample acceptance policy.

6. All Initial and Continuing Calibration Verifications (ICV/CCVs) were within control limits.

7. All Initial and Continuing Calibration Blanks (ICB/CCBs) were within method criteria.

8. The preparation/method blank was within method criteria. Refer to form 3.

9. All ICP Interference Check Standards were within control limits. Refer to form 4.

10. The laboratory control sample (LCS) was within the $80-120 \%$ control limits. Refer to form 7

11. All QC was performed on another client's sample within the same digestion batch.

12. All sample IDs were changed to accommodate the EPA naming convention which allows a maximum of 6 characters on all CLP Forms. Refer to the comments section of form 1 for the original ID.

13. Recoveries on the Laboratory Summary Report and CLP forms will vary depending on the number of significant figures used in the recovery calculation.
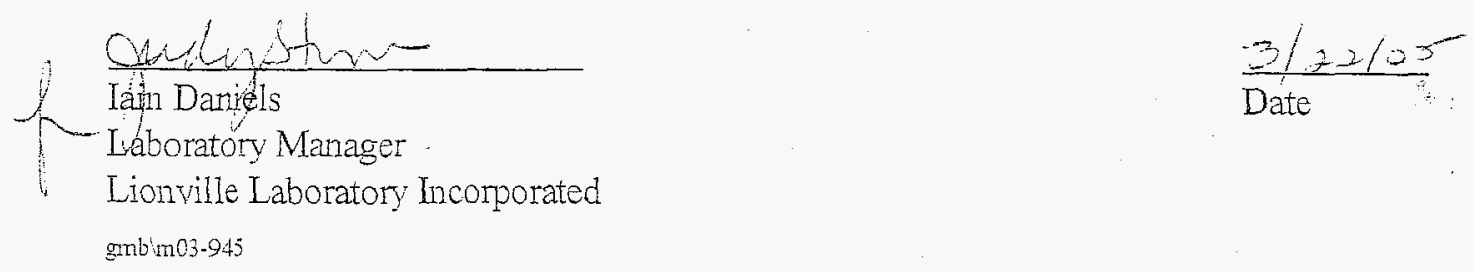

Láboratory Manager

gmbmo3-94j 


\section{METHOD REFERENCES AND DATA QUALIFIERS}

\section{DATA OUALIFIERS}

$\mathrm{U}=$ Indicates that the parameter was not detected at or above the reported limit. The associated numerical value is the sample detection limit.

$\mathrm{B}=$ Indicates that the parameter was between the Instrument Detection Limit (IDL) and the Contract Required Detection Iimit (CRDL)

\section{QQUALIFIERS}

$E=$ The reported value is estimated because of the presence of interference.

$M=$ Duplicate injection precision not met.

$N=$ Spiked sample recovery not within control limits.

$S=\quad$ The reported value was determined by the Method of Standard Additions (MSA).

$\mathrm{W}=$ Post Digestion spike for Furnace AA analysis is out of control limits $(85-115 \%)$, while sample absorbance is less than $50 \%$ of spike absorbance.

* = Duplicate analysis not within control limits.

$+=$ Correlation coefficient for the MSA is less than 0.995 .

\section{ABBREVIATIONS}

$\mathrm{PB}=$ Method or Preparation Blank.

$S=$ Matrix Spike.

$T=$ Matrix Spike Duplicate.

$\mathrm{R}$ or $\mathrm{D}=$ Sample Replicate

\section{ANALYTICAL METAL METHODS}

1. Not included in the method element list.

2. Modified $\mathrm{Hg}$ : $\mathrm{Hg} 1$ and $\mathrm{Hg} 2$ require less total volume of digestate due to the autosampler analysis. Sample volumes and reagents for mercury determinations in water and soil have been proportionately scaled down to adapt to this semiautomated technique. The sample volume used for water analysis is $33 \mathrm{~mL}$. For soils, approximately 0.3 grams of sample is taken to a final volume of $50 \mathrm{~mL}$ (including all reagents).

3. Flame AA.

4. Graphite Furnace AA.

RFW 21-21L-033/0.01/97 
Lionville Laboratory, Inc.

INORGANICS DATA SUMMARY REPORT 03/22/05

CIIENT: BECHTEL NEVADE V2423

WORK ORDER: 60052-001-001-0001-00

$\begin{array}{lll}\text { SAMPLE } & \text { SITE ID } & \text { IIALYTE } \\ ==\pi=== & ================= & ================== \\ -001 & 050801 \mathrm{VI} & \text { Lead, } \text { TotaI }\end{array}$

IVL LOT \#: 0503 I.945

\begin{tabular}{|c|c|c|c|}
\hline & & REPORTING & DILUTION \\
\hline RESULT & UNITS & LIMIT & FECTOR \\
\hline$== \pm===\equiv=$ & $======$ & $=== \pm= \pm===\Omega$ & $====\approx===$ \\
\hline 21.9 & $\mathrm{MG} / \mathrm{KG}$ & 1.2 & 6.0 \\
\hline
\end{tabular}


Lionville Laboratory, Ino.

IHORGPNICS METHOD BLINK DATE SUMMARY RAGE 03/22/05

CIIENT: BECHTEL NEVADA V2423

WORE: ORDER: 50052-001-001-0001-00

\begin{tabular}{|c|c|c|}
\hline SEMPLE & SITE ID & ENAIYTE \\
\hline$=====$ & 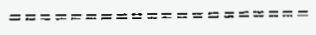 & 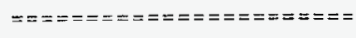 \\
\hline CANSIK1 & $05 L 0143-M B 1$ & Lead, Total \\
\hline
\end{tabular}

LVI LOT

\begin{tabular}{|c|c|c|c|}
\hline & & REPORTING & DILITION \\
\hline RESULT & UNITS & LIMIT & FACTOR \\
\hline 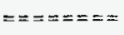 & $== \pm===$ & $==:=-===-=$ = & $\approx= \pm=====$ \\
\hline $0.19 u$ & $M G / K G$ & 0.19 & 1.0 \\
\hline
\end{tabular}


Iionville Laboratory, Inc.

INORGANICS LIBORETORY CONTROL STANDARDS REPORT 03/22/05

CLIENT: BECFTEL NEVEDE V2423

MORK ORDER: 60052-001-001-0001-00

\begin{tabular}{|c|c|c|}
\hline$E$ & SITE ID & MNALYTE \\
\hline$=====$ & 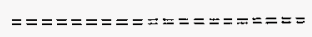 & 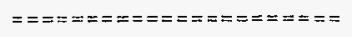 \\
\hline
\end{tabular}

L, CS 1

0510113-LC1 yead, LCS
LVL LOT \#: $0503 \pm 945$

\begin{tabular}{|c|c|c|c|}
\hline SPIKED & SPIKED & & \\
\hline SAMPIE & RMOUNT & UNITS & $\frac{\circ}{6} \mathrm{RECOV}$ \\
\hline$== \pm=$ & $======$ & $== \pm \approx= \pm=$ & $==\approx==\approx$ \\
\hline 47 & 250 & $M G / K G$ & 98 \\
\hline
\end{tabular}




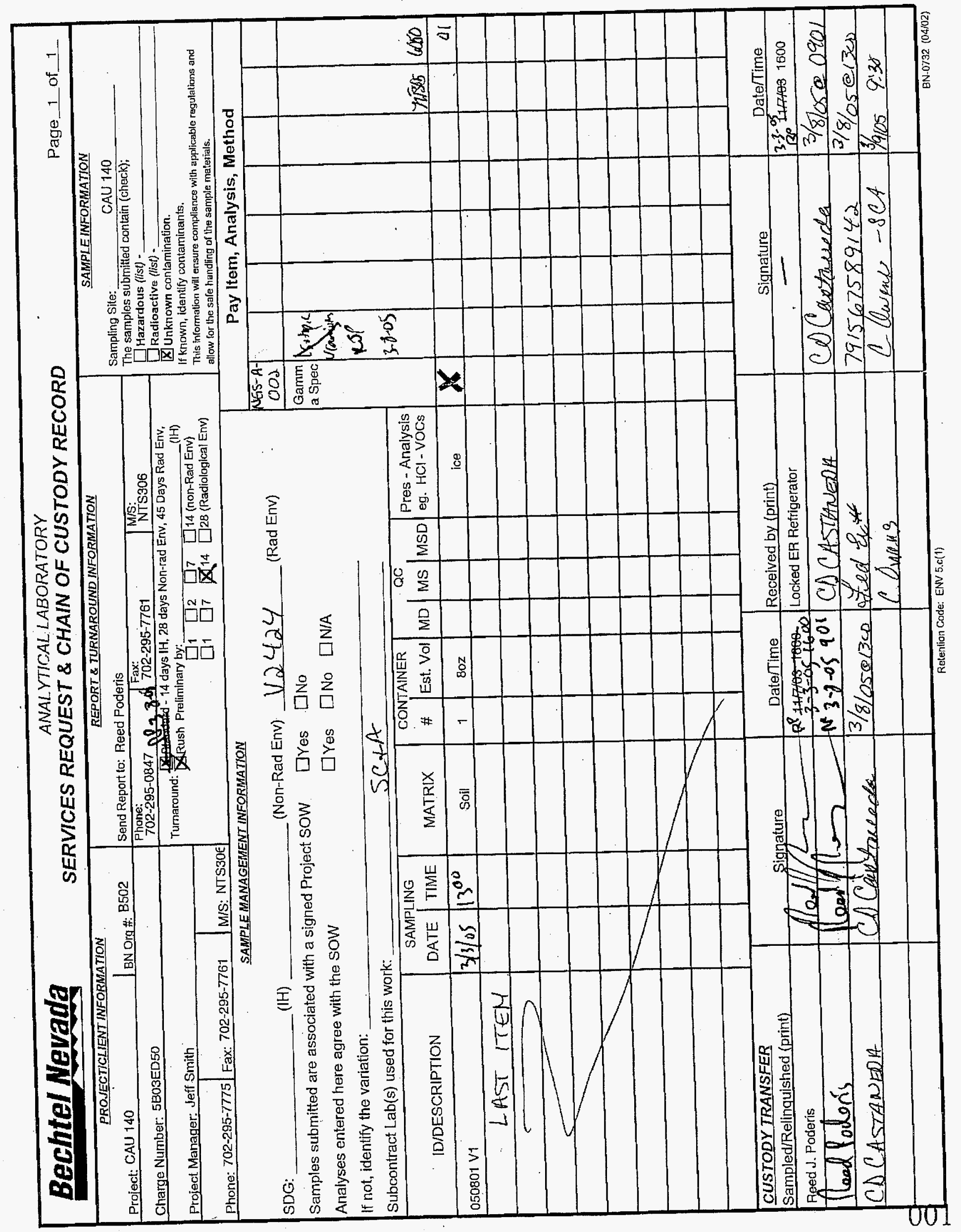




\section{CASE NARRATIVE \\ SDG V2424 \\ Laboratory Report Identification Number: 6050}

March 23, 2005

\section{Introduction}

On March 9, 2005, one soil sample, (SDG V2424), was received for analysis at the Sanford Cohen and Associates (SC\&A) Southeastern Envirommental Laboratory, located in Montgomery, Alabama. The chain-of-custody requested the results to be reported within 14 days of receipt. The sample was analyzed in accordance with the Bechtel Nevada Services Subcontract Task Order Agreement Form, Exhibit B, Statement of Work and Specifications, Rev 1, 1/23/01.

\section{Analytical Methodology}

The radioanalytical results reported for each sample include the site and laboratory sample identification numbers, collection date, method of analysis, and the quality control samples that were analyzed concurrently. Sample was analyzed in accordance with the following method.

\begin{tabular}{|c|c|c|c|}
\hline Radionuclide & $\begin{array}{c}\text { Method } \\
\text { Number }\end{array}$ & \multicolumn{1}{|c|}{$\begin{array}{c}\text { Method } \\
\text { Name }\end{array}$} & $\begin{array}{l}\text { Counting } \\
\text { Method }\end{array}$ \\
\hline $\begin{array}{l}\text { Gamma Emitting } \\
\text { Radionuclides }\end{array}$ & EPA 901.1 & $\begin{array}{l}\text { Gamma Emitting } \\
\text { Radionuclides }\end{array}$ & $\begin{array}{l}\text { Gamma } \\
\text { Spectrometry }\end{array}$ \\
\hline
\end{tabular}

\section{Analytical Results}

\section{Deficiencies}

None.

\section{Matrix Interferences}

There were no indications of matrix interference.

Dilutions

There were no dilutions. 


\section{Detection Limits}

The required detection limits (RDL) were met for all analyses.

$\underline{\text { Re-analysis }}$

There were no re-analysis.

Deviations from Protocols

There were no deviations from the written protocols and analytical methods.

Contacts with the CTR

There was no contact with the CTR regarding these samples.

\section{Quality Control}

Site Samples Used for Quality Control Samples:

\begin{tabular}{|c|c|c|}
\hline Site Sample Number & Laboratory Sample Number & $\begin{array}{c}\text { Type of Quality Control Analysis } \\
\text { Sample }\end{array}$ \\
\hline \hline Laboratory Type II Water & SCAQC-6049-LC1 & Laboratory Control Sample \\
\hline $250706-V 1$ & SCAQC-6049-LD1 & Laboratory Duplicate Sample \\
\hline Laboratory Type II Water & SCAQC-6049-PB1 & Preparation Blank \\
\hline
\end{tabular}

The analytical results of all quality control samples met the acceptance criteria specified in the SOW.

Sincerely,

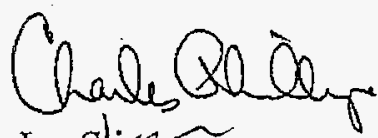
Joe stingson 


\section{Sanford Cohen \& Associates \\ Southeastern Environmental Laboratory}

Radioanalytical Results

Report Identification Number: V2424

\begin{tabular}{|c|c|c|c|c|c|c|}
\hline \multicolumn{2}{|c|}{$\begin{array}{l}\text { Project Name: Bechtel Nevada } \\
\text { Site Sample ID: } 050801 \mathrm{V1} \\
\text { Other Sample ID: }\end{array}$} & \multicolumn{3}{|c|}{ Chain-of-Custody Number; } & \multicolumn{2}{|c|}{ Matrix: Soil } \\
\hline Method Number & Radionuclide & $\begin{array}{l}\text { Laboratory } \\
\text { Sample ID }\end{array}$ & $\begin{array}{l}\text { Activity } \\
\text { (pCila) }\end{array}$ & $\begin{array}{l}2 \sigma \text { TPU } \\
(\mathrm{pCi} / \mathrm{g})\end{array}$ & $\begin{array}{l}\text { Total Error } \\
\text { (pCiig) } \\
\end{array}$ & $\begin{array}{c}\text { MDA } \\
\text { (pCifg) }\end{array}$ \\
\hline EPA 901.1 & $B E-7$ & NTS05-6050-01 & -0.061 & 0.177 & 0.177 & 0.293 \\
\hline EPA 901.1 & $K-40$ & NTS05-6050-01 & 34.0 & 2.11 & 4.00 & 0.260 \\
\hline EPA 901.1 & $\mathrm{CO}-60$ & NTS05-6050-01 & -0.003 & 0.025 & 0.025 & 0.032 \\
\hline EPA 901.1 & $Y-88$ & NTS05-6050-01 & -0.003 & 0.014 & 0.014 & 0.024 \\
\hline EPA 901.1 & RU-106 & NTS05-6050-01 & 0.053 & 0.178 & 0.178 & 0.297 \\
\hline EPA 901.1 & SB-125 & NTSO5-6050-01 & -0.002 & 0.051 & 0.051 & 0.086 \\
\hline EPA 901.1 & CS-134 & NTS05-6050-01 & -0.013 & 0.021 & 0.024 & 0.029 \\
\hline EPA 901.1 & CS-137 & NTS05-6050-01 & 0.052 & 0.035 & 0.035 & 0.037 \\
\hline EPA 901.1 & CE-144 & NTS05-6050-01 & 0.340 & 2.70 & 2.70 & 0.259 \\
\hline EPA 901.1 & PM-144 & NTS05-6050-01 & 0.004 & 0.019 & 0.019 & 0.030 \\
\hline EPA 901.1 & PM-146 & NTS05-6050-01 & 0.017 & 0.025 & 0.025 & 0.043 \\
\hline EPA 901.1 & EU-152 & NTS05-6050-01 & 0.037 & 0.059 & 0.059 & 0.093 \\
\hline EPA 901.1 & EU-154 & NTS05-6050-01 & 0.002 & 0.042 & 0.042 & 0.069 \\
\hline EPA 901.1 & EU-155 & NTS05-6050-01 & 0.580 & 0.127 & 0.140 & 0.144 \\
\hline EPA 901.1 & PB-212 & NTS05-6050-01 & 2.34 & 0.154 & 0.279 & 0.060 \\
\hline EPA 901.1 & TH-234 & NTS05-6050-01 & 21.2 & 1.60 & 2.66 & 0.750 \\
\hline EPA 901.1 & U-235 & NTS05-6050-01 & 0.343 & 0.222 & 0.224 & 0.049 \\
\hline EPA 901.1 & U-238 & NTS05-6050-01 & 38.6 & 6.70 & 7.73 & 5.83 \\
\hline EPA 901.1 & $A M-241$ & NTS05-6050-01 & 0.257 & 0.191 & 0.192 & 0.302 \\
\hline
\end{tabular}

\begin{tabular}{|llll|}
\hline Radionuclide & \multicolumn{2}{c}{ Quality Control Samples } & Laboratory Control (LC) \\
Gamma & $\frac{\text { Laboratory Duplicate (LD) }}{\text { SCAQC-6049-LC1 }}$ & Matrix Spike (MS) & Preparation Blank (PB) \\
\hline
\end{tabular}


SaMPle ANALYTICAL Results

CAS 05-08-02, DEBRIS PITS 
Closure Report - CAU 140

Section: Appendix D

Revision: 0

Date: August 2005

THIS PAGE INTENTIONALLY LEFT BLANK 


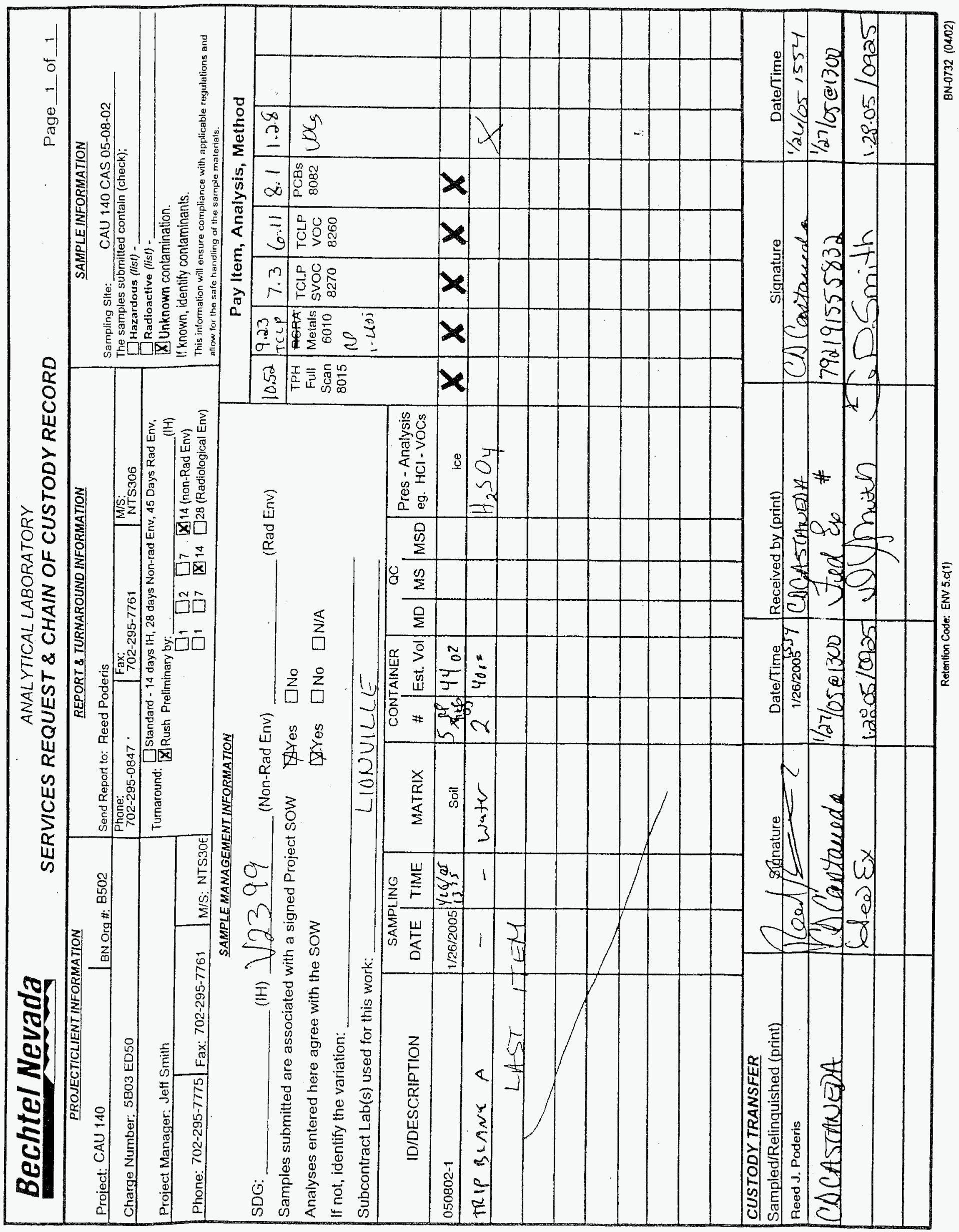


Client: BECHTEL-NEVADA V2399

W.O. \#: 60052-001-001-0001-00

LVL \#: 0501L696

Date Received: 01-28-2005

\section{DIESEL RANGE ORGANICS}

One (1) soil sample was collected on 01-26-2005.

The sample and its associated QC samples were extracted on 01-31-2005 and analyzed according to Lionville Laboratory SOPs on 02-04-2005. The extraction procedure was based on method 3540C and the extracts were analyzed based on method $8015 \mathrm{~B}$ for Diesel Range Petroleum Hydrocarbons.

1. All results presented in this report are derived from a sample that met LvLI's sample acceptance policy.

2. The sample was extracted and analyzed within required holding time.

3. The method blank was below the reporting limits for all target compounds.

4. All surrogate recoveries were within acceptance criteria.

5. The blank spike recovery was within acceptance criteria.

6. The matrix spike recoveries were within acceptance criteria.

7. The initial calibrations associated with this data set were within acceptance criteria.

8. The continuing calibration standards prior to sample extracts were within acceptance criteria.

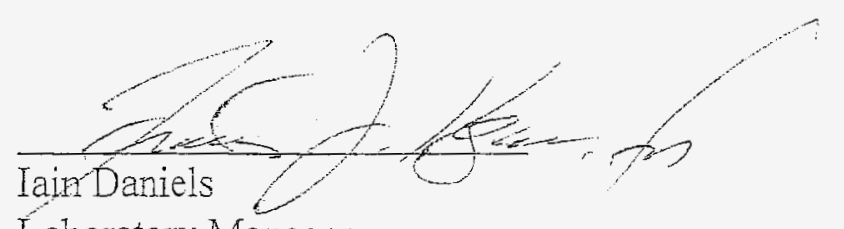

Laboratory Manager

Lionville Laboratory Incorporated

somiriteroupldataidrolbecheel $0501-695$, doc

000000004 


\section{GLOSSARY OF DATA}

\section{DATA QUALIFIERS}

$\mathrm{U}=$ Indicates that the compound was analyzed for but not detected. The minimum detection limit for the sample (not the method detection limit) is reported with the $\mathrm{U}$ (e.g., 10U).

$\mathbf{J}=$ Indicates an estimated value. This flag is used in cases where a target analyte is detected at a level less than the lower quantification level. If the limit of quantification is $10 \mathrm{ug} / \mathrm{L}$ and a concentration of $3 \mathrm{ug} / \mathrm{L}$ is calculated, it is reported as $3 \mathrm{~J}$.

B = This flag is used when the analyte is found in the associated blank as well as in the sample. It indicates possible/probable blank contamination.

$\mathbf{E}=$ Indicates that the compound was detected beyond the calibration range and was subsequently analyzed at a dilution.

$1=$ Interference.

$.1=$ Indicates an interference on one analytical column only. Result is reported from remaining analytical column.

\section{ABBREVIATIONS}

BS = Indicates blank spike in which reagent grade water is spiked with the CLP matrix spiking solutions and carried through all the steps in the method. Spike recoveries are reported.

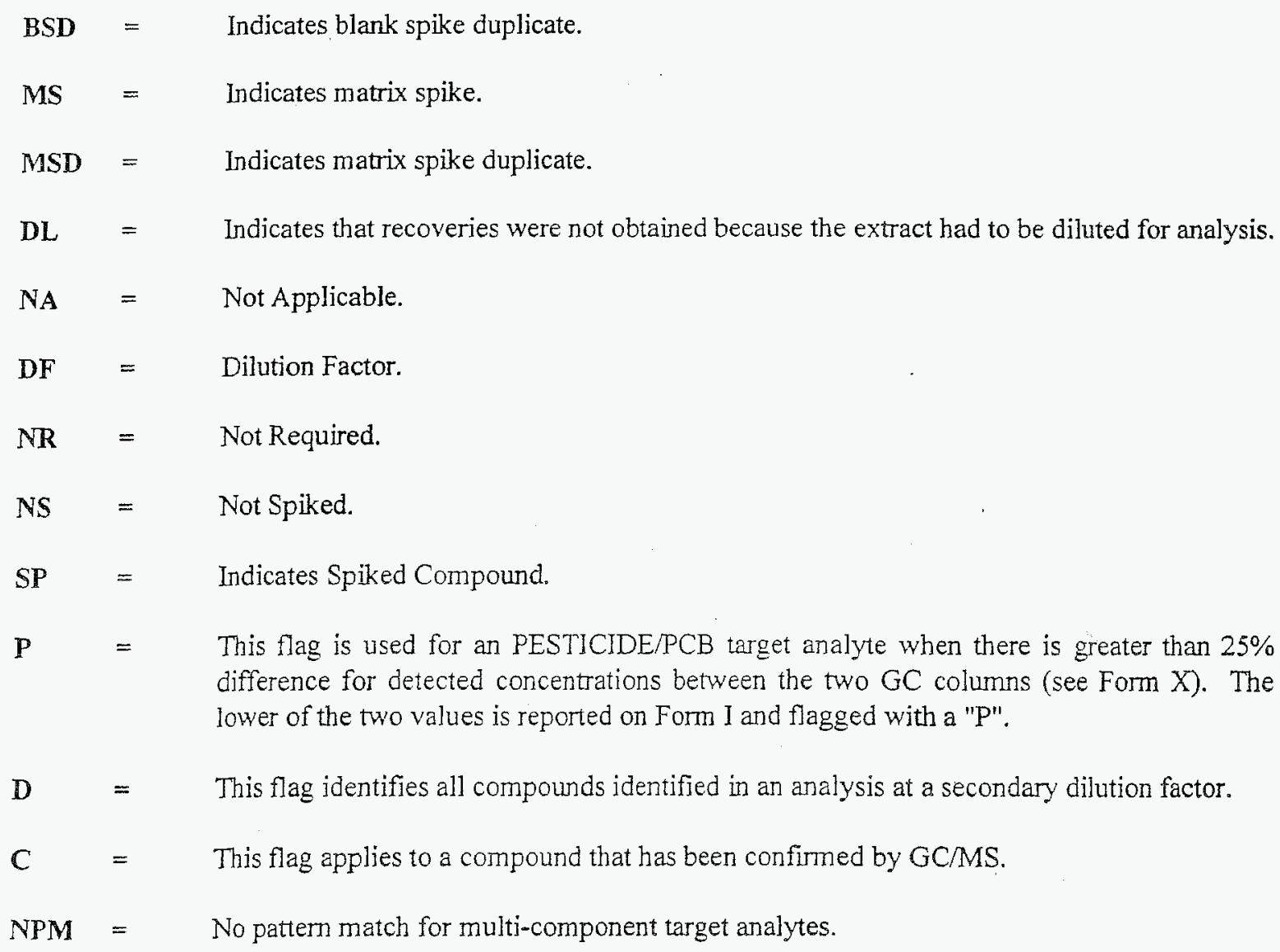




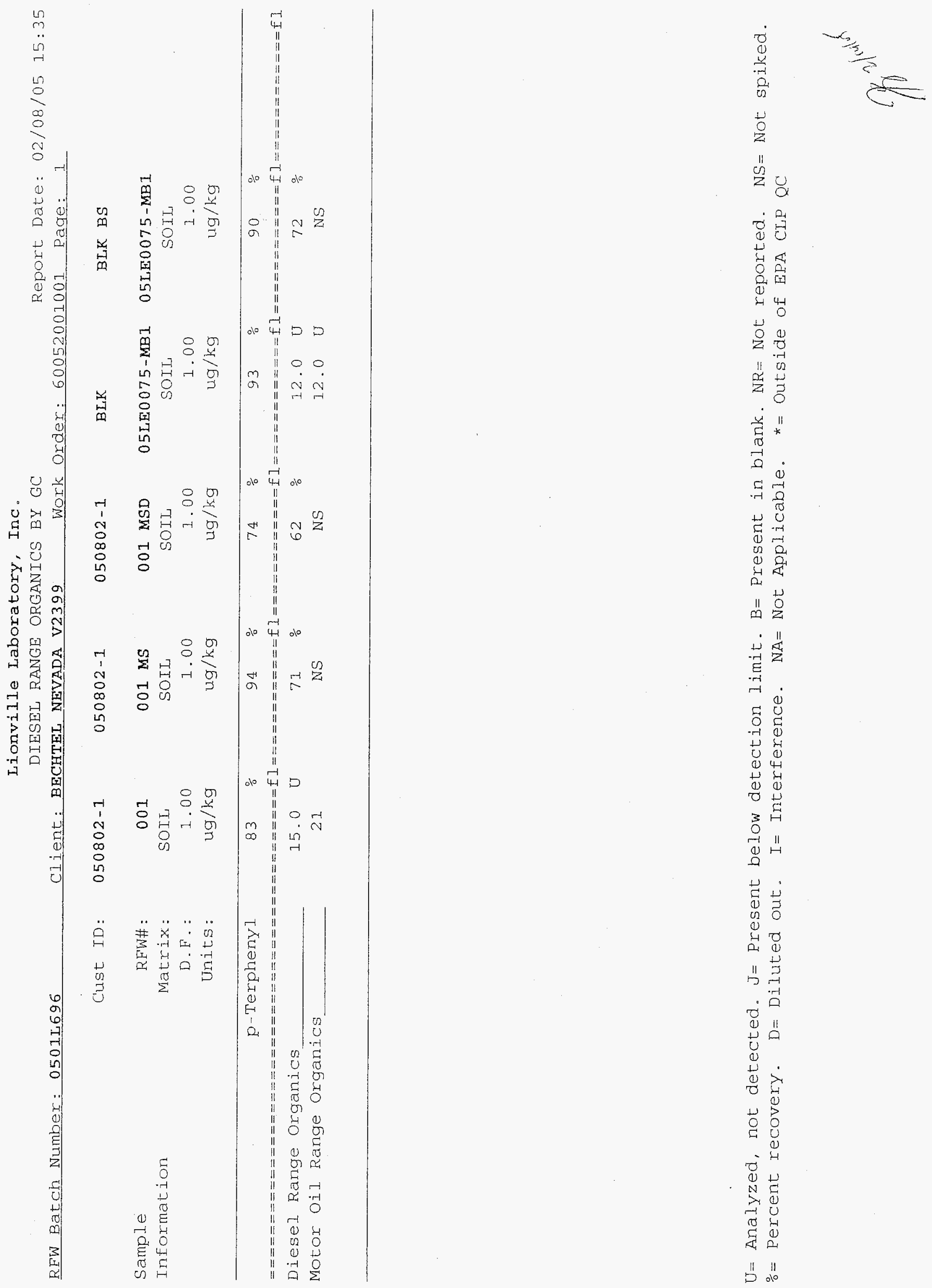




\section{Case Narrative}

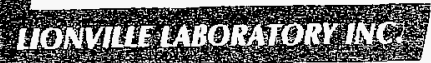

Client: BECHTEL-NEVADA V2399

LVL \#:0501L696
W.O. \#: 60052-001-001-0001-00

Date Received: 01-28-2005

\section{GRO}

One (1) soil sample was collected on 01-26-2005.

The sample and its associated QC samples were analyzed according to Lionville Laboratory SOPS based on SW-846 method 8015B for Gasoline Range Organics (GRO) on 02-01-2005.

The following is a summary of the QC results accompanying these sample results and a description of any problems encountered during their analyses:

1. All results presented in this report are derived from a sample that met LVLI's sample acceptance policy.

2. The sample was analyzed within required holding time.

3. The method blank was below the reporting limit for the target compound.

4. All surrogate recoveries were within acceptance criteria.

5. The blank spike recovery was within acceptance criteria.

6. The matrix spike recoveries were within acceptance criteria.

7. All initial calibrations associated with this data set were within acceptance criteria.

8. The closing CCV was outside the acceptance criteria for the surrogate and the target compound; however, the target compound was not detected in the sample. A copy of the Sample Discrepancy Report (SDR) has been enclosed.
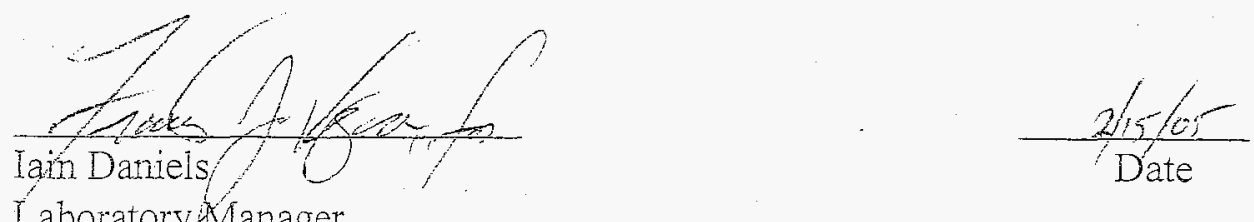

Laboratory Kanager

Lionville Laboratory Incorporated

somitgroupldatalGRO10501-696,doc 


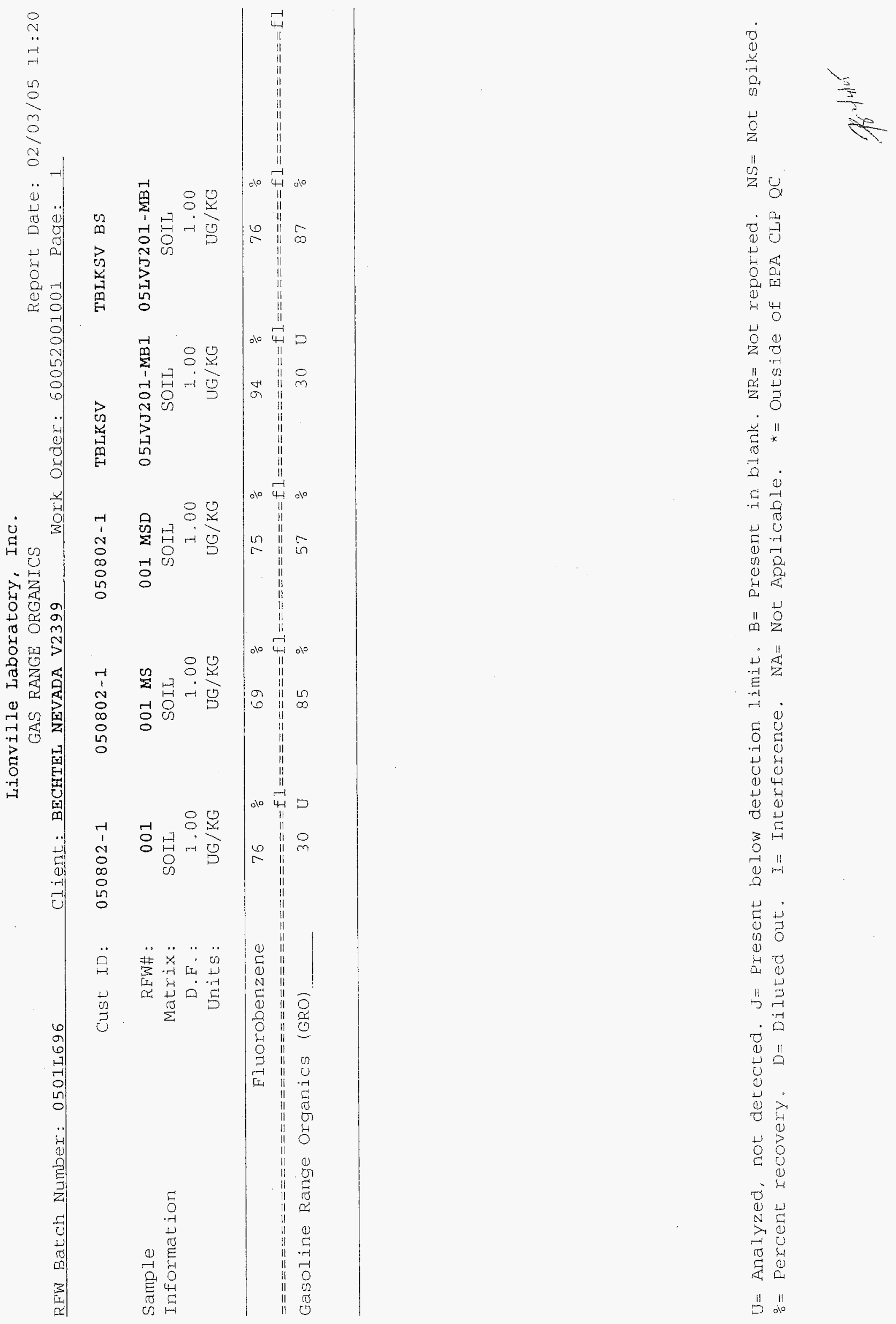


Client : BECHTEL NEVADA V2399

LVL\# : 0501L696
W.O.\# : 60052-001-001-9999-00

Date Received : 01-28-05

\section{SW846 METALS}

1. This narrative covers the analysis of 1 TCLP leachate sample.

2. The sample was prepared and analyzed in accordance with SW-846 protocol and reported with a CLP deliverable. The samples were run with six fold dilutions for ICP analytes due to sample matrix.

3. ICVs, CCVs, and LCSs stock standards were purchased from Inorganic Ventures Laboratory and High Purity.

4. All analyses were performed within the required holding times.

5. All results presented in this report are derived from samples that met LvLI's sample acceptance policy.

6. All Initial and Continuing Calibration Verifications (ICV/CCVs) were within control limits with the exception of the ending CCVs for Barium. All samples were surrounded by CCVs in control.

7. All Initial and Continuing Calibration Blanks (ICB/CCBs) were within method criteria.

8. All preparation/method blanks were within method criteria. Refer to form 3.

9. All ICP Interference Check Standards were within control limits. Refer to form 4.

10. All laboratory control samples (LCS) were within the $80-120 \%$ control limits. Refer to form 7.

11. All serial dilution percent differences were within SW-846 control limits. Refer to form 9 .

12. The TCLP extract from sample 050802-1 was selected for the matrix spike (MS) for this analytical batch. The MS recoveries for all analytes in the TCLP extract were above 50\% per method criteria. 
13. Ail sample IDs were changed to accommodate the EPA naming convention which allows a maximum of 6 characters on all CLP Forms. Refer to the comments section of form 1 for the original ID

14. Recoveries on the Laboratory Summary Report and CLP forms will vary depending on the number of significant figures used in the recovery calculation.

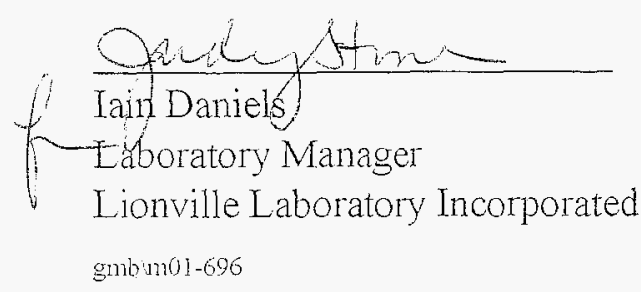

$\frac{2 / 1510}{\text { Date }}$

Eåboratory Manager

gnb $1301-696$

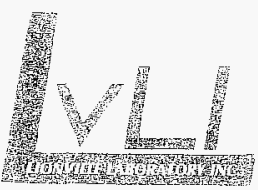


INORGANICS DATA SUMMARY REPORT 02/09/05

CLIENT: BECHTEI NEVADE V2399

WORK ORDER: 60052-001-001-0001-00

\begin{tabular}{|c|c|c|}
\hline SAMPLE & SITE ID & FINALTTE \\
\hline$=== \pm===$ & $====-==$ = = = = = = = = = = = = & $==\equiv=$ = = = = = \\
\hline-004 & $050802-1$ & $\begin{array}{l}\text { Silver, TCLP Leachate } \\
\text { Prsenic, TCLP Leachate } \\
\text { Barium, TCLP Leachate } \\
\text { Cadmium, TCLP Leachate } \\
\text { Chromium, TCLP Leachate } \\
\text { Mercury, TCLP Leachate } \\
\text { Lead, TCLP Leachate } \\
\text { Selenium, TCLP Leachate }\end{array}$ \\
\hline
\end{tabular}

LVL LOT \#: OSO1LE96

\begin{tabular}{|c|c|c|c|c|}
\hline & & & REPORTING & DILUTION \\
\hline RESULT & & UNITS & IIMIT & FACTOR \\
\hline$====\mp=0$ & & $=====$ = & $== \pm=====\approx=$ & $z===\approx=z=z$ \\
\hline 3.0 & $u$ & $\mathrm{UG} / \mathrm{I}$ & 3.0 & 6.0 \\
\hline 29.5 & & $U G / L$ & 17.4 & 6.0 \\
\hline 1040 & & $U G / I$ & 1.2 & 6.0 \\
\hline 2.4 & $\mathrm{LI}$ & $\mathrm{UG} / \mathrm{I}$ & 2.4 & 6.0 \\
\hline 2.4 & $u$ & $\mathrm{UG} / \mathrm{L}$ & 2.4 & 6.0 \\
\hline 0.88 & & UG $/ \mathrm{L}$ & 0.10 & 1.0 \\
\hline 11.4 & $\mathrm{u}$ & $\mathrm{UG} / \mathrm{I}$ & 11.4 & 6.0 \\
\hline 21.0 & $\mathrm{u}$ & $\mathrm{UG} / \mathrm{L}$ & 24.0 & 6.0 \\
\hline
\end{tabular}


Litonville Laboratory, Inc.

INORGPNICS METHOD EILAMT DETA SUMMARY PAGE 02/09/05

CLIENT: BECHTEL NEVADA V2399

WORK ORDER: 60052-001-001-0001-00

$\begin{array}{ll}\text { SAMPLE } & \text { SITE ID } \\ =\neq= \pm=== & ==================== \\ \text { BIANKI } & \text { 05L0065-MB } 1\end{array}$

BLANC2 05L0065-MB2

BLANK3

$05[0065-\mathrm{MB} 3$

$\begin{array}{lll}\text { BLANIK1 } & \text { 05C0025-MB1 } & \text { Mercury, TCLP Leachate } \\ \text { BLANK2 } & 0500025-M B 2 & \text { Mercury, TCLP Leachate } \\ \text { BIANK3 } & 0500025-M B 3 & \text { Mercury, TCLP Leachate } \\ \text { ELANK4 } & 0500025-M B 4 & \text { Mercury, TCLP Leachate } \\ \text { BLAINK5 } & 0500025-M B 5 & \end{array}$

INALYTE

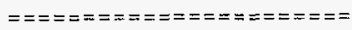

Silver, TCLP Leachate

Arsenic, TCLP Leachate

Barium, TCLP Leachate

Cadmium, TCLP Leachate

Chromium, TCLP Leachate

Lead, TCLP Leachate

Selenium, TCre Eeachate

Silver, TCLP Leachate

Arsenic, TCIP Leachate

Barium, TCLP Leachate

Cadmium, TCLP Leachate

Chromium, TCLP Leachate

Lead, TCLP Leachate

selenium, TCLP Leachate

Silver, TCLP Leachate

Arsenic, TCuP Leachate

Barium, TCLP Leachate

Cadmium, TCLP Leachate

Chromium, TCLP Leachate

Lead, TCLP Leachate

selenium, TCLP Ieachate

LVL LOT $\frac{H}{*}: 05011696$

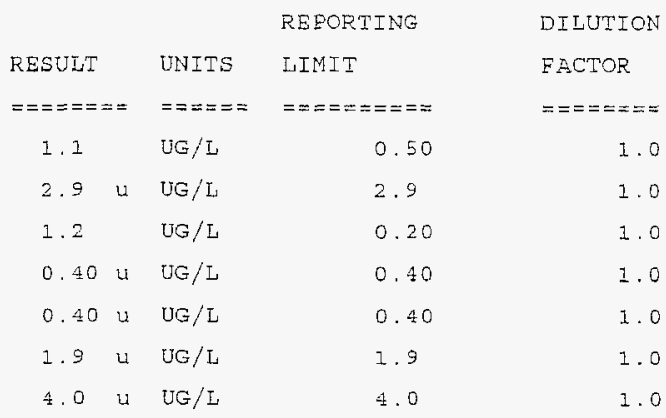

$5.5 \quad \mathrm{UG} / \mathrm{L}$

17.4 u UG/L

$1.6 \mathrm{UG} / \mathrm{I}$

2.4 U UG/L

2.4 ᄂ UG/L

11.4 U $\mathrm{UG} / \mathrm{I}$

24.0 บ UG/I

3.0 บ UG/L

$17.4 \cup \quad$ UG $/ \mathrm{L}$

$7.8 \quad \mathrm{UG} / \mathrm{I}$

2.4 u UG $/ \mathrm{J}$

11.3 UG/L

$11.4 \cup \mathrm{UG} / \mathrm{I}$

24.0 ᄂ UE/L

$0.10 \mathrm{U}$ UG/L

$0.10 \cup \mathrm{UG} / \mathrm{L}$

3.0

17.4

1. 2

2,4

2.4

11.4

24.0

3.0

17.4

1. 2

2. 4

2,4

11.4

24.0

0.10

0.10

$0.10 \mathrm{U}$ UG/L $0.10 \quad 1.0$

$\begin{array}{llll}0.39 & \text { UG } / \mathrm{O} & 0.10 & 1.0\end{array}$

$\begin{array}{lll}0.39 \text { UG } / I \quad 0.10 & 1.0\end{array}$

$0.10 \cup \mathrm{UG} / \mathrm{L}$

0.10

6.0

6.0

6.0

6.0

6.0

6.0

5.0

6.0

6.0

6.0

6.0

6.0

6.0

6.0

1.0

1.0

1. 0 
CLIENT: BECHTEL NEVADA V2399

WORK ORDER: 50052-001-001-0001-00
LVL LOT \#

\begin{tabular}{|c|c|c|c|c|c|}
\hline & SPIKED & INITIEI & SETIKED & & DILUTION \\
\hline LYTE & SAMPLE & RESULT & BMOUNT & $\because R E C O V$ & FACTOR (SPK) \\
\hline 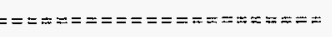 & $======$ & $=======$ & $\approx=====$ & $=======$ & $=z==-=z=z=$ \\
\hline ver, TCLP Leachate & 4330 & $3.0 \mathrm{u}$ & 5000 & 86.5 & 6.0 \\
\hline enic, ICLP Leachate & 5010 & 29.5 & 5000 & 99.7 & 6.0 \\
\hline rium, TCLP Leachate & 99600 & 1040 & 100000 & 98.5 & 6.0 \\
\hline Imium, TCLP Leachate & 984 & 2.44 & 1000 & 98.4 & 6.0 \\
\hline omium, TCLP Leachat & 4920 & $2.4 u$ & 5000 & 98.5 & 5.0 \\
\hline ury, TCLP Leachate & 192 & 0.88 & 200 & 95.4 & 50.0 \\
\hline TCLP L & 5120 & $11.4 u$ & 5000 & 102.3 & 6.0 \\
\hline nium, & 1050 & $24.0 \mathrm{u}$ & 1000 & 105.1 & 6.0 \\
\hline
\end{tabular}


Lionvilie Laboratory, Inc.

INORGANICS LAEORATORY CONTROL STANDARDS REPORT 02/09/05

\begin{tabular}{|c|c|c|c|c|c|c|}
\hline \multirow{2}{*}{\multicolumn{3}{|c|}{$\begin{array}{l}\text { CLIENT: BECHTEL NEVADA V2399 } \\
\text { WORE ORDER: 60052-001-001-0001-00 }\end{array}$}} & \multicolumn{4}{|c|}{ LVI LOT $\#$ : 0501L696 } \\
\hline & & & SPIKED & SPIKED & & \\
\hline SAVPLE & STTE ID & PNALYTE & SAMFLE & AMOUNT & UNITS & sRECOV \\
\hline$===== \pm$ & 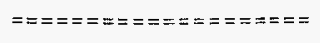 & 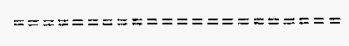 & $=====$ & $\Rightarrow=\approx \approx==$ & $=z====$ & $===-==$ \\
\hline \multirow[t]{7}{*}{ LCS1 } & $05 L 0055-\mathrm{LCI}$ & Silver, LCS & 492 & 500 & UG $/ \mathrm{L}$ & 98.4 \\
\hline & & Arsenic, LCS & 9560 & 10000 & $\mathrm{UG} / \mathrm{L}$ & 95.6 \\
\hline & & Barium, LCS & 4950 & 5000 & $\mathrm{UG} / \mathrm{L}$ & 99.0 \\
\hline & & Cadmium, ICS & 247 & 250 & $\mathrm{UG} / \mathrm{L}$ & 98.7 \\
\hline & & Chromium, LCS & 500 & 500 & $\mathrm{UG} / \mathrm{L}$ & 99.9 \\
\hline & & Lead, LCS & 2500 & 2500 & UG $/ \mathrm{L}$ & 100.0 \\
\hline & & Selenium, LCS & 9460 & 10000 & $\mathrm{UG} / \mathrm{L}$ & 94.6 \\
\hline $\operatorname{LCS} 1$ & $05 \mathrm{C0025- \textrm {LCl }}$ & Mercury, LCS & 4.9 & 5.0 & $\mathrm{UG} / \mathrm{L}$ & 98.7 \\
\hline
\end{tabular}




\section{Case Narrative}

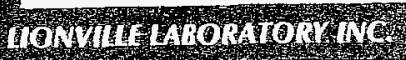

Client: BECHTEL-NEVADA V2399

LVL \#: 0501L696

W.O. \#: 60052-001-001-0001-00

Date Received: 01-28-2005

\section{SEMIVOLATILE-TCLP}

One (1) leachate sample was generated on 02-05-2005 from a soil sample collected on 01-26-2005.

The sample and its associated QC șamples were extracted according to Lionville Laboratory SOPS based on SW 846 method $3520 \mathrm{C}$ on $02-06-2005$ and analyzed according to criteria set forth in Lionville Laboratory SOPs based on method 8270C for TCLP Semivolatile target compounds on 0208-2005.

The following is a summary of the QC results accompanying the sample results and a description of any problems encountered during their analyses:

1. All results presented in this report are derived from a sample that met LvLI's sample acceptance policy.

2. The sample was extracted and analyzed within required holding time.

3. The sample was extracted at a 5-fold dilution (200 mL has been used instead of $1000 \mathrm{~mL})$ due to the leachate sample matrix.

4. One (1) of thirty-six (36) surrogate recoveries was outside acceptance criteria. However, the surrogate recovery criteria were met (i.e., no more than one outlier per fraction \{acid and base neutral $\}$ and no recoveries less than $10 \%$ ).

5. Two (2) of twenty-four (24) matrix spike recoveries were outside acceptance criteria.

6. All blank spike recoveries were within acceptance criteria.

7. Internal standard area and retention time criteria were met.

8. Mamual integrations are performed according to SOP QA-125 to produce quality data with the utmost integrity. All manual integrations are required to be technically valid and properly documented. Appropriate technical flags are defined in the Glossary ("Technical Flags For Manual Integration").
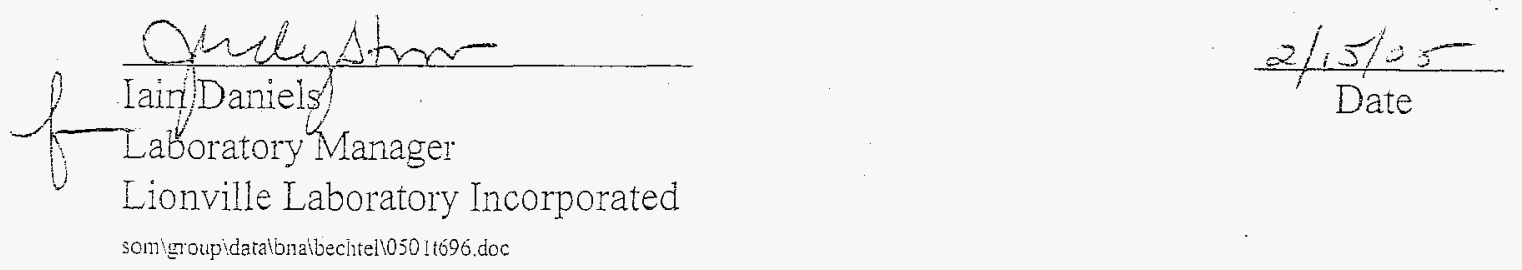


\section{GLOSSARY}

\section{DATA QUAIIFIERS}
$\mathrm{U}=$ Compound was analyzed for but not detected. The associated numerical value is the estinated sample quantitation limit which is included and corrected for dijution and percent moisture.
$\mathrm{J}=$ Indicates an estimated value. This flag is used under the following circumstances: 1) when estimating a concentration for tentatively identified compounds (TICs) where a $1: 1$ response is assumed; or 2) when the mass spectral data indicate the presence of a compound that meets the identification criteria but the result is less than the specified detection limit but greater than zero. For example, if the limit of detection is $10 \mathrm{ug} / \mathrm{L}$ and a concentration of $3 \mathrm{ug} / \mathrm{L}$ is calculated, it is reported as 33 .

B = This flag is used when the analyte is found in the associated blank as well as in the sample. It indicates possible/probable blank contamination. This flag is also used for a TIC as well as for a positively identified TCL compound.

E = Indicates that the compound was detected beyond the calibration range and was subsequently analyzed at a dilution.

D = Identifies all compounds identifjed in an analysis at a secondary dilution facior.

$1=$ interference.

NQ $=$ Result qualitatively confirmed but not able to quantify.

A $=$ Indicates that a TIC is a suspected aldol-condensation product.

$N=$ Indicates presumptive evidence of a compound. This flag is only used for tentatively identified compounds (TICs), where the identification is based on a mass spectral library search. It is applied to all TIC results. For generic characterization of a TIC, such as chlorinated hydrocarbon, the $\mathrm{N}$ code is not used.

$\mathrm{X}=$ This flag is used for a TIC compound which is quantified relative to a response factor generated from a daily calibration standard (rather than quantified relative to the closest internal standard).

$y=$ Additional qualifiers used as required are explained in the case narrative.

mmzl10-94kgloss.bna

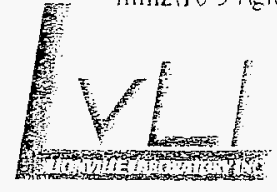




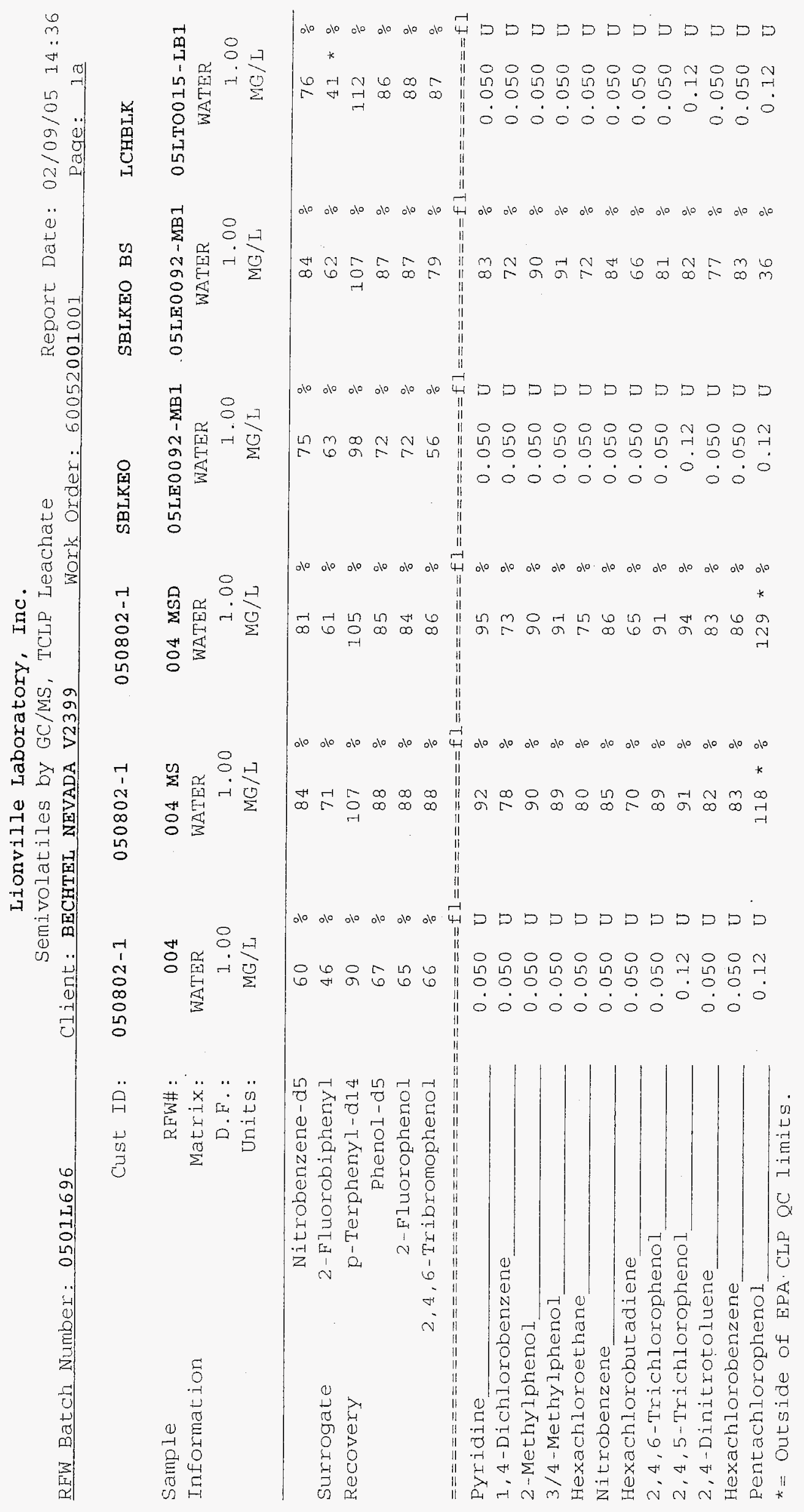




\section{Case Narrative}

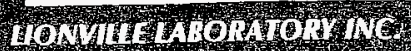

Client: BECHTEL-NEVADA V2399

W.O. \#: 60052-001-001-0001-00

LVL \#: $0501 \mathrm{~L} 696$

Date Received: 01-28-2005

\section{GC/MS VOLATILE-TCLP}

The set of samples consisted of one (1) leachate and one (1)-water samples collected on 01-26-2005. The leachate sample was generated from a soil sample on 02-08-2005.

The samples and their associated QC samples were analyzed according to criteria set forth in Lionville Laboratory SOPs based on SW 846 Method 8260B for TCLP Volatile target compounds on 02-08,09. 2005.

The following is a summary of the QC results accompanying the sample results and a description of any problems encountered during their analyses:

1. All results presented in this report are derived from samples that met LvLI's sample acceptance policy.

2. The required holding time for analysis was met.

3. The leachate sample 050802-1 required a 5-fold dilution due to high levels of target compounds.

4. All surrogate recoveries were within acceptance criteria.

5. All matrix spike recoveries were within acceptance criteria.

6. All blank spike recoveries were within acceptance criteria.

7. Internal standard area and retention time criteria were met.

8. Manual integrations are performed according to SOP QA-125 to produce quality data with the utmost integrity. All manual integrations are required to be technically valid and properly documented. Appropriate technical flags are defined in the Glossary ("Technical Flags For Manual Integration").
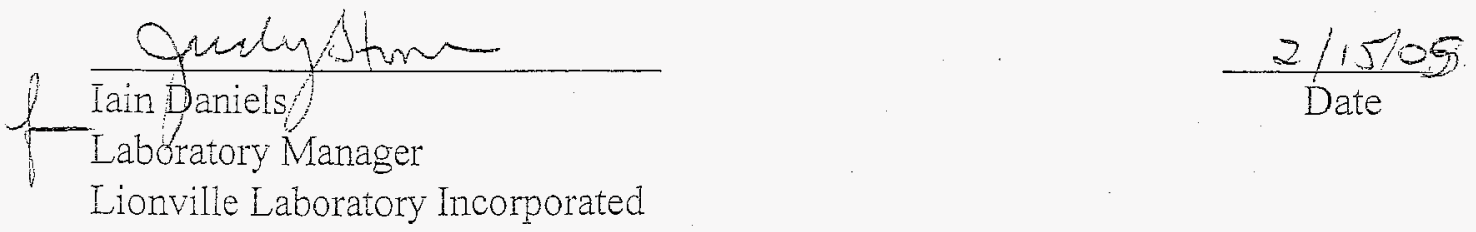

somigroupidatatroabectel-nevadalo $501+696 \mathrm{dm}$ 


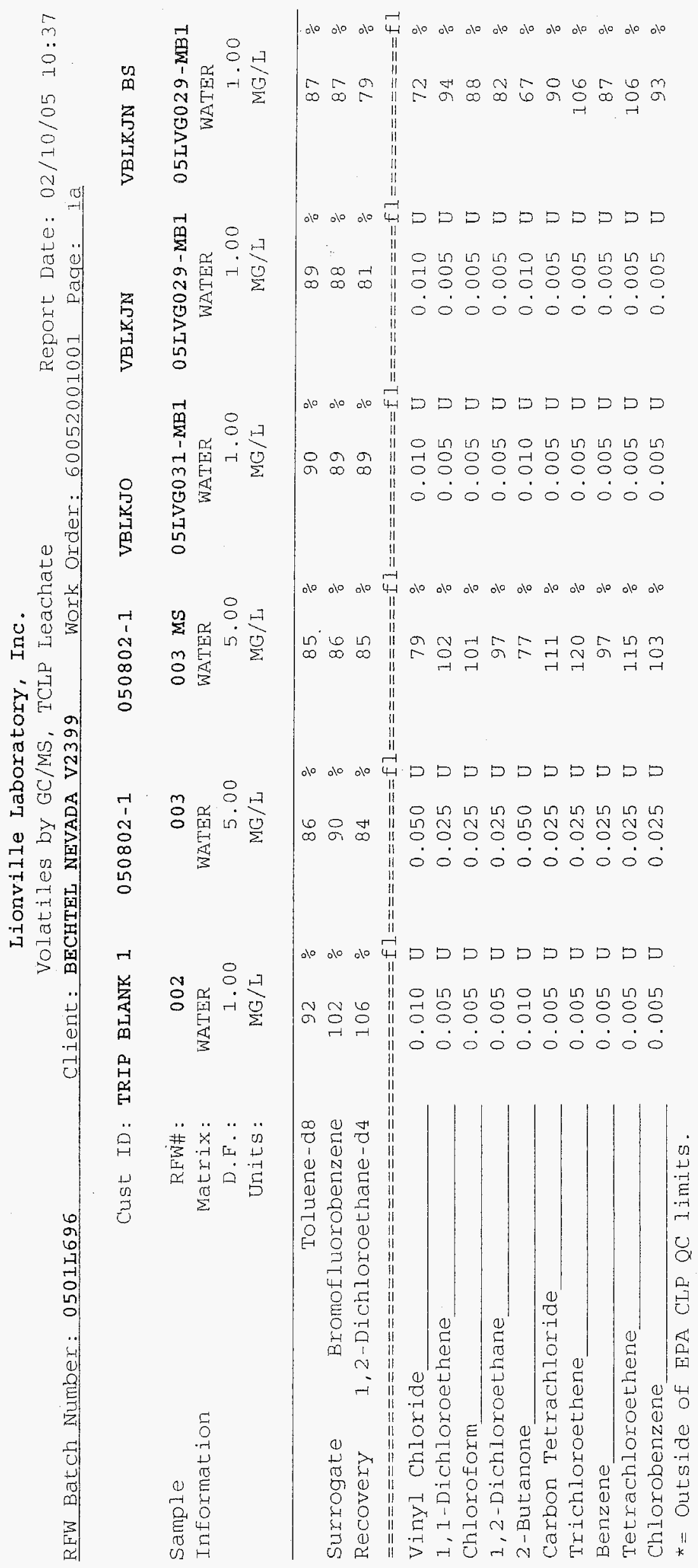




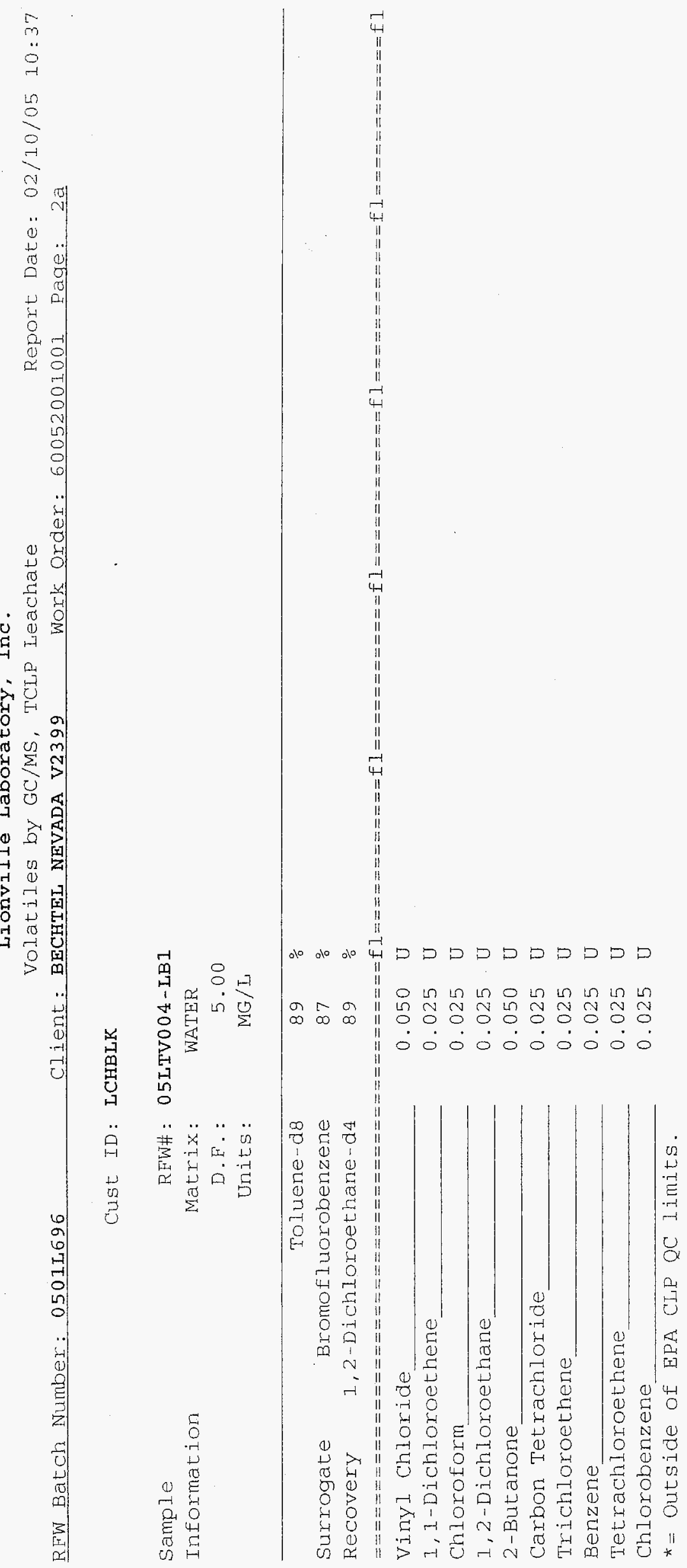




\section{Case Narrative}

Client: BECHTEL-NEVADA V2399

LVL \#:0501I696
W.O. \#: 60052-001-001-0001-00

Date Received: 01-28-2005

\section{PCB}

One (1) soil sample was collected on 01-26-2005.

The sample and its associated QC samples were extracted on 02-04-2005 and analyzed according to Lionville Laboratory SOPS on 02-08-2005. The extraction procedure was based on method $3540 \mathrm{C}$ and the extracts were analyzed based on method 8082 .

The following is a summary of the QC results accompanying the sample results and a description of any. problems encountered during their analyses:

1. All results presented in this report are derived from a sample that met LVLI's sample acceptance policy.

2. The required holding time for extraction and analysis was met.

3. The sample and its associated QC samples received Copper-Sulfur and Sulfuric Acid cleanups according to Lionville Laboratory SOPs based on SW846 methods 3660A and 3665A respectively.

4. The method blank was below the reporting limits for all target compounds.

5. All surrogate recoveries were within acceptance criteria.

6. The blank spike recoveries were within acceptance criteria.

7. All matrix spike recoveries were within acceptance criteria.

8. The initial calibration associated with this data set was within acceptance criteria.

9. The continuing calibration standard analyzed prior to sample extract was within acceptance criteria.
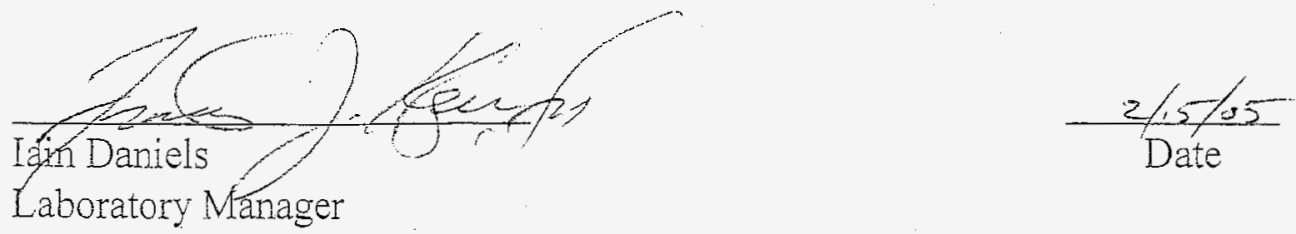

Lionville Laboratory Incorporated

somirigroupidatalpest bechitel10501-696.n.h 


\section{GLOSSARY OF DATA}

\section{DATA QUALIFIERS}
$\mathrm{U}=$ Indicates that the compound was analyzed for but not detected. The minimum detection limit for the sample (not the method detection limit) is reported with the U (e.g., 10U).
$\mathrm{J}=$ Indicates an estimated value. This flag is used in cases where a target analyte is detected at a level less than the lower quantification level. If the limit of quantification is $10 \mathrm{ug} / \mathrm{L}$ and a concentration of $3 \mathrm{ug} / \mathrm{L}$ is calculated, it is reported as $3 \mathrm{~J}$.
B = This flag is used when the analyte is found in the associated blank as well as in the sample. It indicates possible/probable blank contamination.
$\mathbf{E}=$ Indicates that the compound was detected beyond the calibration range and was subsequently analyzed at a dilution.
$1=$ Interference.
.I = Indicates an interference on one analytical column only. Result is reported from remaining analytical column.

\section{ABBREVIATIONS}

BS = Indicates blank spike in which reagent grade water is spiked with the CLP matrix spiking solutions and carried through all the steps in the method. Spike recoveries are reported.
BSD $=$ Indicates blank spike duplicate.
MS = Indicates matrix spike.
MSD $=$ Indicates matrix spike duplicate.
DL = Indicates that recoveries were not obtained because the extract had to be diluted for analysis.
NA $=$ Not Applicable.
DF $=$ Dilution Factor.
NR $=\quad$ Not Required.
NS $=$ Not Spiked.
$\mathrm{SP} \quad=\quad$ Indicates Spiked Compound.
$\mathrm{P}=\quad$ This flag is used for an PESTICIDE $P C B$ target analyte when there is greater than $25 \%$ difference for detected concentrations between the two GC columns (see Form $X$ ). The lower of the two values is seported on Form I and flagged with a "P".
$\mathrm{D}=\quad$ This flag identifies all compounds identified in an analysis at a secondary dilution factor.
C = This flag applies to a compound that has been confurmed by GCMS.
NPM = No pattern match for multi-component target analytes. 


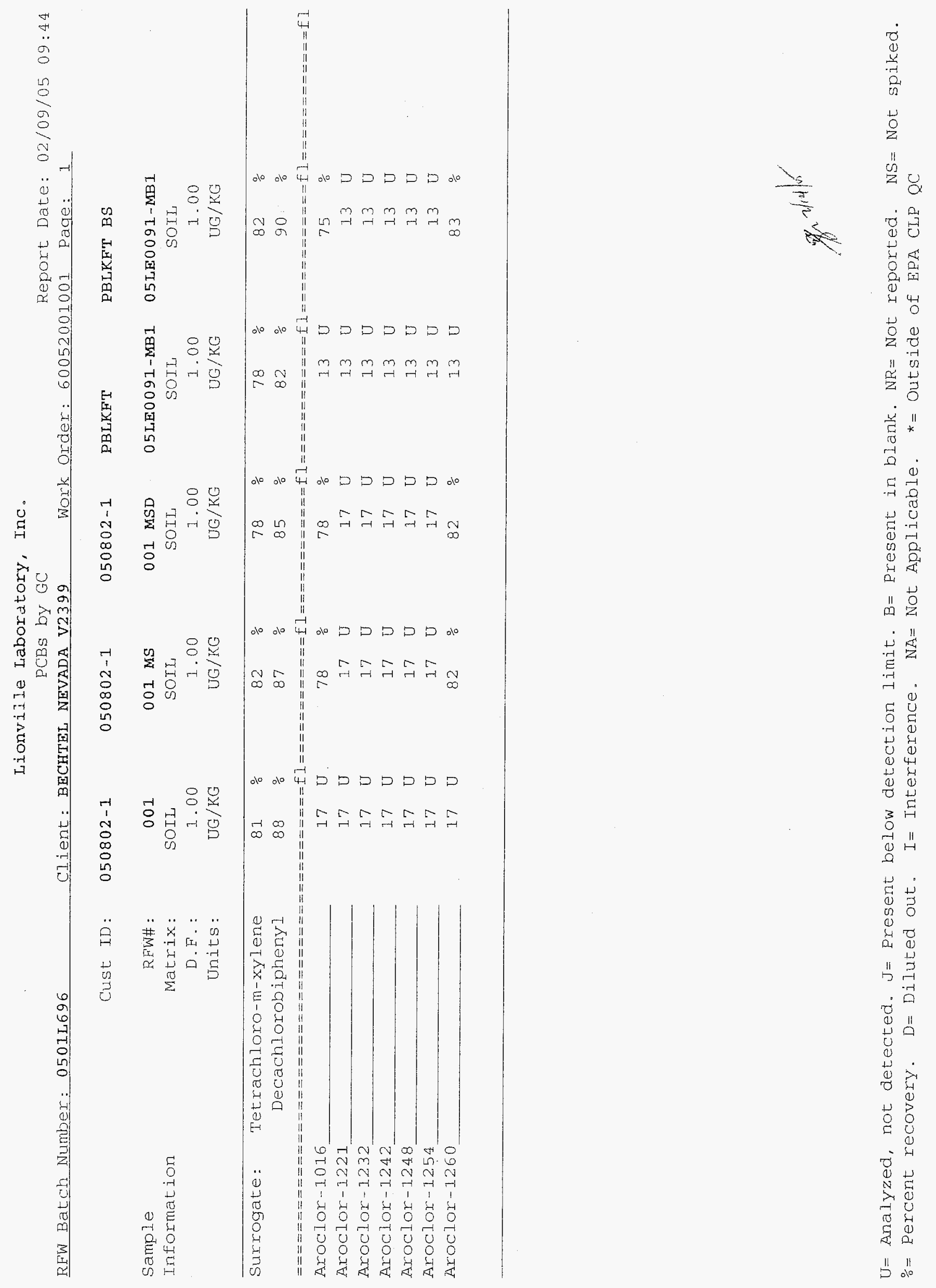




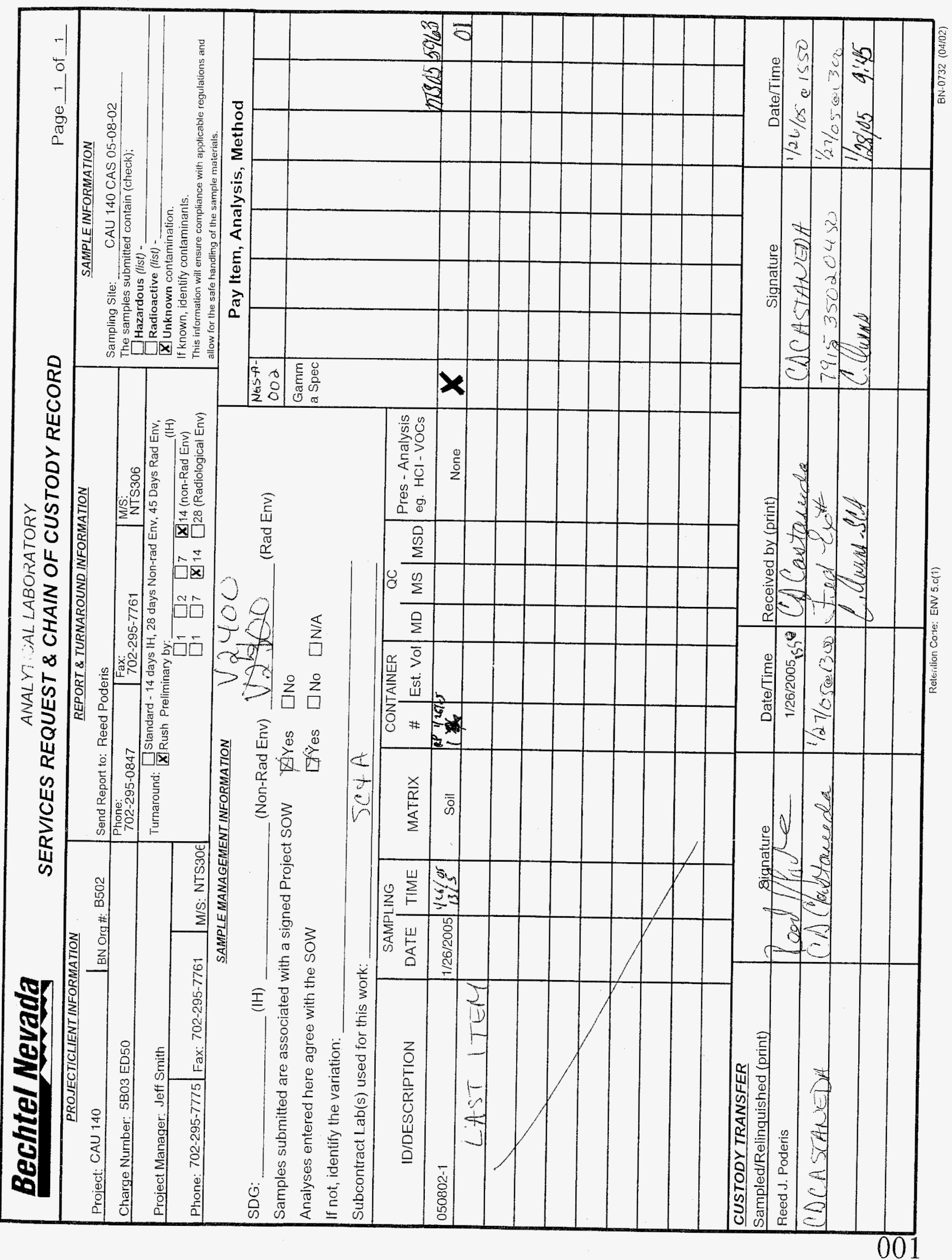




\section{CASE NARRATIVE \\ SDG V2400 \\ Laboratory Report Identification Number: 5963}

February 11,2005

\section{Introduction}

On January 28, 2005, one soil sample, (SDG V2400), was received for analysis at the Sanford Cohen and Associates (SC\&A) Southeastern Environmental Laboratory, located in Montgomery, Alabama.. The sample was analyzed in accordance with the Bechtel Nevada Services Subcontract Task Order Agreement Form, Exhibit B, Statement of Work and Specifications, Rev 1, 1/23/01.

\section{Analytical Methodology}

The radioanalytical results reported for each sample include the site and laboratory sample identification numbers, collection date, method of analysis, and the quality control samples that were analyzed concurrently. Sample was analyzed in accordance with the following method.

\begin{tabular}{|c|c|l|l|}
\hline Radionuclide & $\begin{array}{c}\text { Method } \\
\text { Number }\end{array}$ & $\begin{array}{c}\text { Method } \\
\text { Name }\end{array}$ & $\begin{array}{l}\text { Counting } \\
\text { Method }\end{array}$ \\
\hline \hline $\begin{array}{l}\text { Gamma Emitting } \\
\text { Radionuclides }\end{array}$ & EPA 901.1 & $\begin{array}{l}\text { Gamma Emitting } \\
\text { Radionuclides }\end{array}$ & $\begin{array}{l}\text { Gamma } \\
\text { Spectrometry }\end{array}$ \\
\hline
\end{tabular}

\section{Analytical Results}

Deficiencies

None.

Matrix Interferences

There were no indications of matrix interference.

\section{Dilutions}

There were no dilutions.

\section{Detection Limits}

The required detection limits (RDL) were met for all analyses. 
$\underline{\text { Re-analysis }}$

There were no re-analysis.

Deviations from Protocols

There were no deviations from the written protocols and analytical methods.

Contacts with the CTR

There was no contact with the CTR regarding these samples.

\section{Quality Control}

Site Samples Used for Quality Control Samples:

\begin{tabular}{|c|c|c|}
\hline Site Sample Number & Laboratory Sample Number & $\begin{array}{c}\text { Type of Quality Control Analysis } \\
\text { Sample }\end{array}$ \\
\hline \hline Laboratory Type II Water & SCAQC-5963-LC1 & Laboratory Control Sample \\
\hline 050802-1 & SCAQC-5963-LD1 & Laboratory Duplicate Sample \\
\hline Laboratory Type II Water & SCAQC-5963-PB1 & Preparation Blank \\
\hline
\end{tabular}

The analytical results of all quality control samples met the acceptance criteria specified in the SOW.

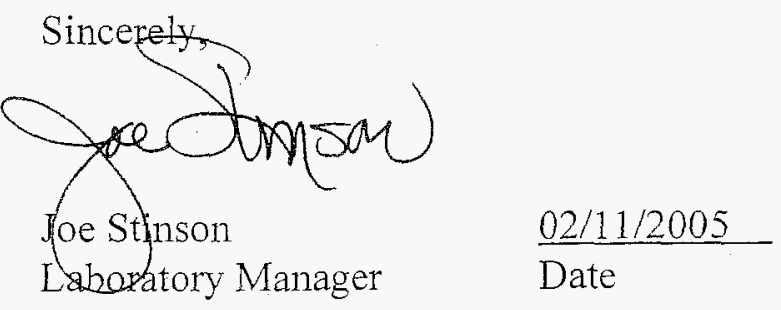




\section{Sanford Cohen \& Associates \\ Southeastern Environmental Laboratory}

\section{Radioanalytical Results}

Report Identification Number: V2400

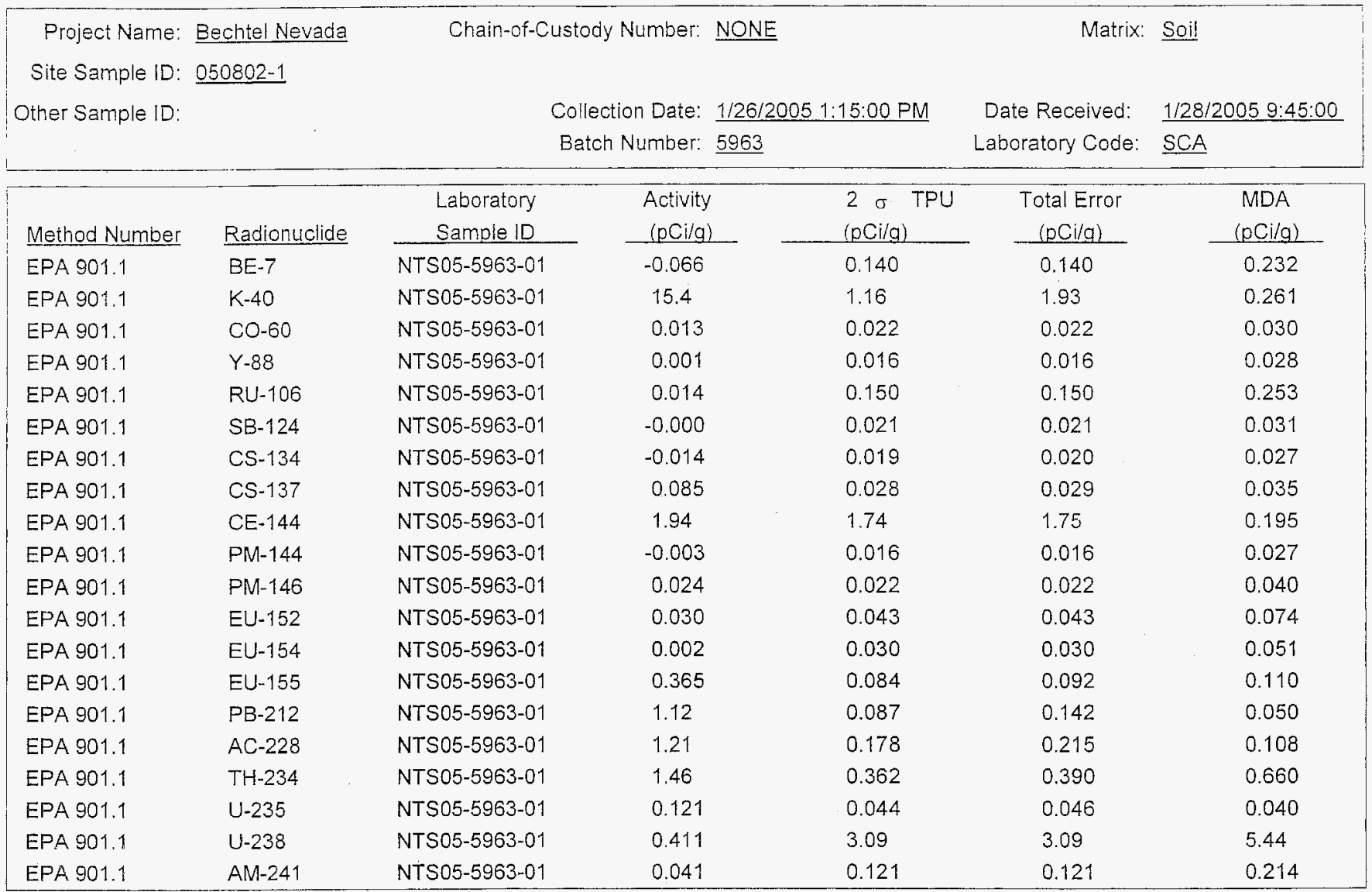

\begin{tabular}{|cllll}
\hline Radionuclide & Quality Control Samples & Laboratory Control (LC) \\
Gamma & $\frac{\text { Laboratory Duplicate (LD) }}{\text { SCAQC-5963-LC1 }}$ & Matrix Spike (MS) & $\frac{\text { Preparation Blank (PB) }}{\text { SCAQC-5963-LD1 }}$ & \\
\hline
\end{tabular}


Closure Report - CAU 140

Section: Appendix D

Revision: 0

Date: August 2005

Sample Analytical Results

\section{CAS 05-17-01, HaZARdous WASTE ACCUMUlation Site (BURIED)}


Closure Report - CAU 140

Section: Appendix D

Revision: 0

Date: August 2005

THIS PAGE INTENTIONALLY LEFT BLANK 


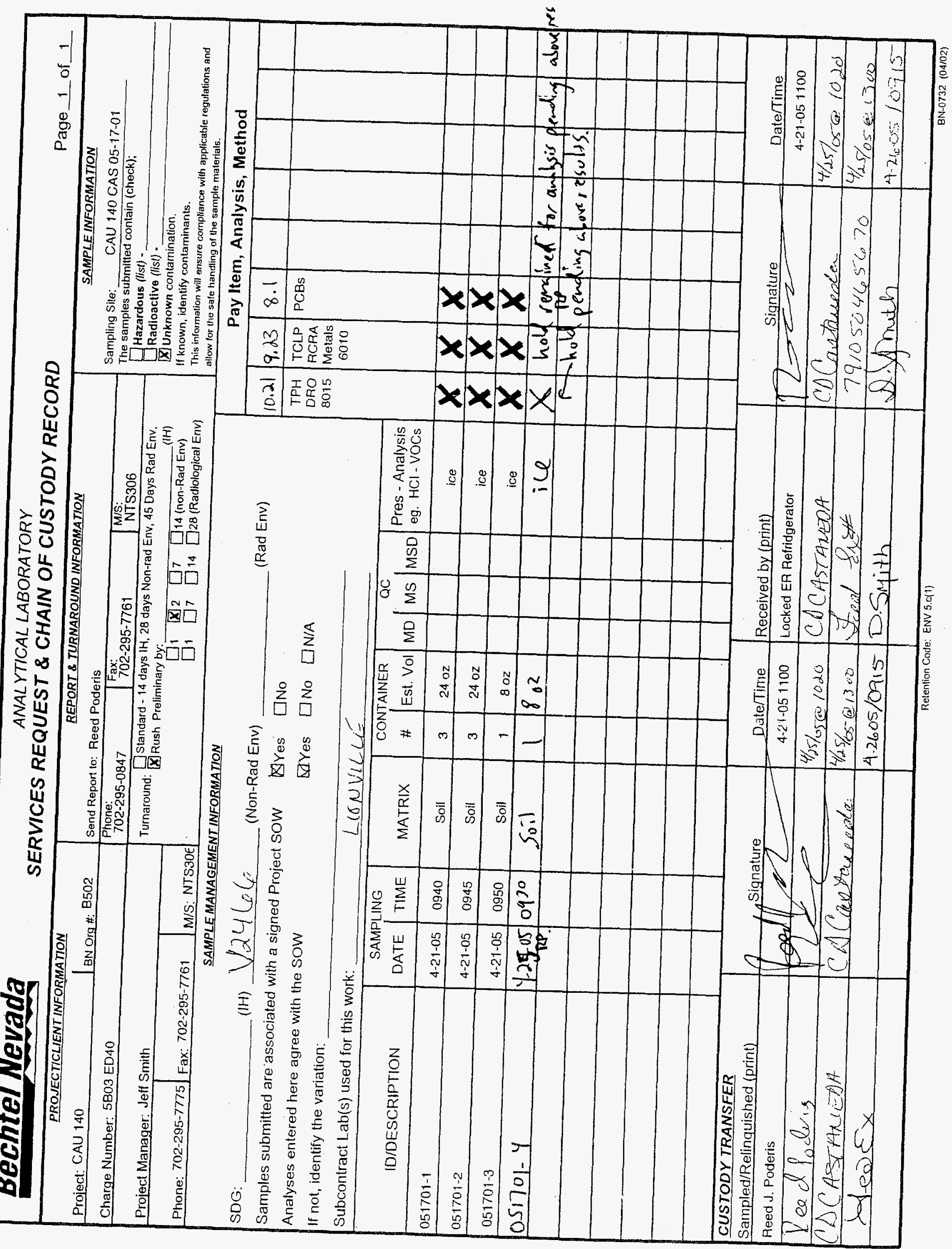




\section{Case Narrative}

Client: BECHTEL-NEVADA V2466

LVL \#: 0504L310
W.O. \#: 60052-001-001-0001-00

Date Received: 04-26-2005

\section{DIESEL RANGE ORGANICS}

Four (4) soil samples were collected on 04-21,25-2005.

The samples and their associated QC samples were extracted on 04-26-2005, 05-03-2005 and analyzed according to Lionville Laboratory SOPS on 04-29-2005 and 05-02,04-2005. The extraction procedure was based on method $3540 \mathrm{C}$ and the extracts were analyzed based on method $8015 \mathrm{~B}$ for Diesel Range Organics.

1. All results presented in this report are derived from samples that met LvLI's sample acceptance policy.

2. Samples were extracted and analyzed within required holding time.

3. The method blank was below the reporting limits for all target compounds.

4. All obtainable surrogate recoveries were within acceptance criteria.

5. The blank spike recoveries were within acceptance criteria.

6. The matrix spike recoveries were within acceptance criteria.

7. Several samples required 50 to 100 -fold dilution due to high concentration of target analytes.

8. The initial calibrations associated with this data set were within acceptance criteria.

9. The continuing calibration standard analyzed prior to sample extracts were within acceptance criteria.
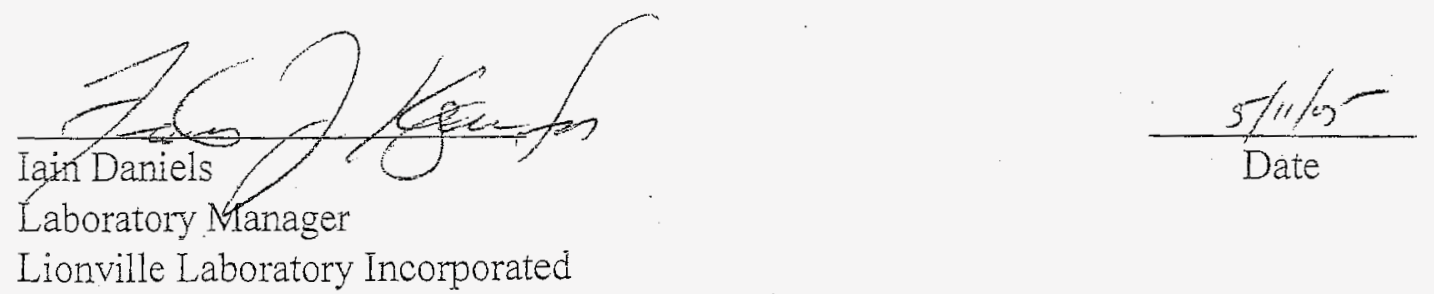


\section{GLOSSARY OF DATA}

\section{DATA QUALIFIERS}

$\mathrm{U}=$ Indicates that the compound was analyzed for but not detected. The minimum detection limit for the sample (not the method detection limit) is reported with the U (e.g., 10U).

$\mathbf{J}=\quad$ Indicates an estimated value. This flag is used in cases where a target analyte is detected at a level less than the lower quantification level. If the limit of quantification is $10 \mathrm{ug} / \mathrm{L}$ and a concentration of $3 \mathrm{ug} / \mathrm{L}$ is calculated, it is reported as $3 \mathrm{~J}$.

B = This flag is used when the analyte is found in the associated blank as well as in the sample. It indicates possible/probable blank contamination.

$\mathbf{E}=$ Indicates that the compound was detected beyond the calibration range and was subsequently analyzed at a dilution.

$1=$ Interference.

$.1=$ Indicates an interference on one analytical column only. Result is reported from remaining analytical column.

\section{ABBREVIATIONS}

BS = Indicates blank spike in which reagent grade water is spiked with the CLP matrix spiking solutions and carried through all the steps in the method. Spike recoveries are reported.

BSD $=$ Indicates blank spike duplicate.

MS $\quad=\quad$ Indicates matrix spike.

MSD = Indicates matrix spike duplicate.

$\mathrm{DL}=$ Indicates that recoveries were not obtained because the extract had to be diluted for analysis.

NA $=$ Not Applicable.

DF $\quad=\quad$ Dilution Factor.

NR $=\quad$ Not Required.

NS $\quad=\quad$ Not Spiked.

SP $\quad=\quad$ Indicates Spiked Compound.

$P \quad=\quad$ This flag is used for an PESTICIDE/PCB target analyte when there is greater than $25 \%$ difference for detected concentrations between the two GC columns (see Form X). The lower of the two values is reported on Form I and flagged with a "P".

D = This flag identifies all compounds identified in an analysis at a secondary dilution factor.

$\mathrm{C}=$ This flag applies to a compound that has been confirmed by GC/MS.

$\mathrm{NPM}=\quad$ No pattern match for multi-component target analytes. 


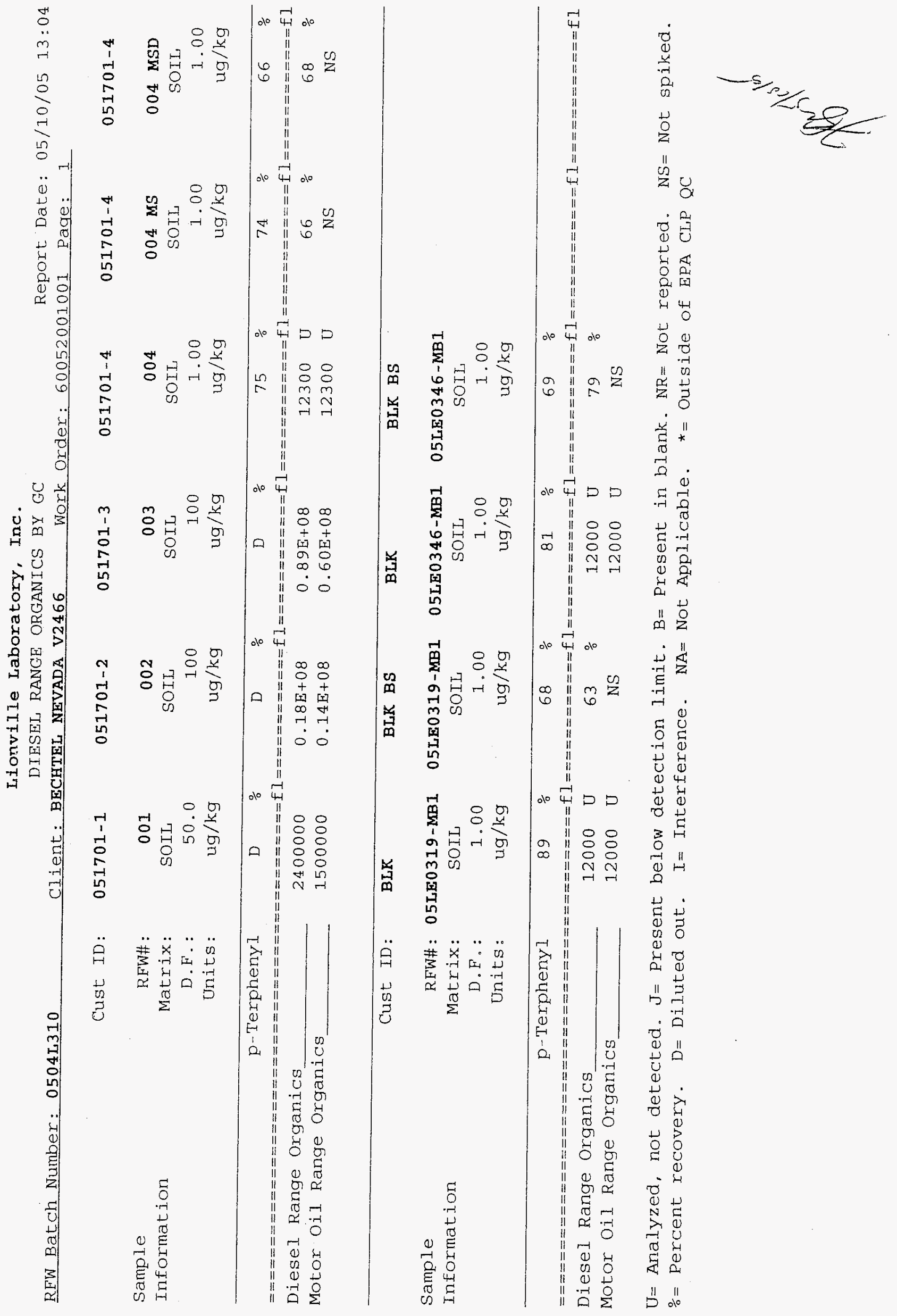




\section{Case Narrative}

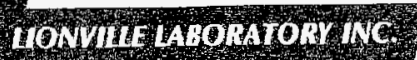

Client: BECHTEL-NEVADA V2466

LVL \#: 0504L310

W.O.\#: 60052-001-001-0001-00

Date Received: 04-26-2005

\section{GRO}

One (1) soil sample was collected on 04-25-2005.

The sample and its associated QC samples were analyzed according to Lionville Laboratory SOPs based on SW-846 method 8015B for Gasoline Range Organics (GRO) on 05-03-2005.

The following is a summary of the QC results accompanying these sample results and a description of any problems encountered during their analyses:

1. All results presented in this report are derived from a sample that met LVLI's sample acceptance policy.

2. The sample was analyzed within required holding time.

3. The method blank was below the reporting limit for the target compound.

4. All surrogate recoveries were within acceptance criteria.

5. The blank spike recovery was within acceptance criteria.

6. The matrix spike recoveries were within acceptance criteria.

7. All initial calibrations associated with this data set were within acceptance criteria.

8. The continuing calibration standard analyzed prior to sample extracts were within acceptance criteria.

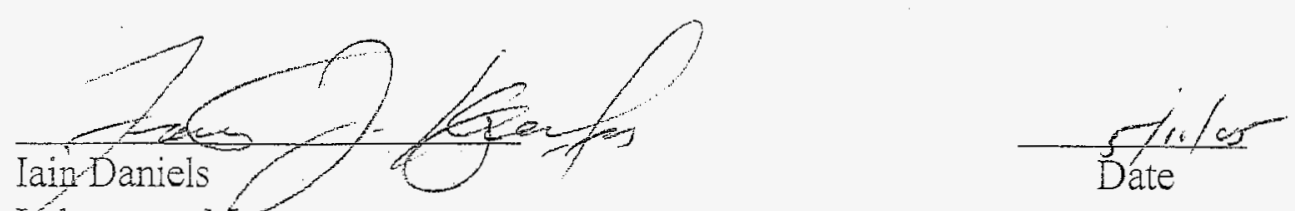

Eaboratory Manager

Lionville Laboratory Incorporated

som W GroupldataiGRO10504-310.doc 


\section{GLOSSARY OF DATA}

\section{DATA QUALIFIERS}

$\mathbf{U}=$ Indicates that the compound was analyzed for but not detected. The minimum detection limit for the sample (not the method detection limit) is reported with the U (e.g., 10U).

$\mathrm{J}=\quad$ Indicates an estimated value. This flag is used in cases where a target analyte is detected at a level less than the lower quantification level. If the limit of quantification is $10 \mathrm{ug} / \mathrm{L}$ and a concentration of $3 \mathrm{ug} / \mathrm{L}$ is caiculated, it is reported as $3 \mathrm{~J}$.

B = This flag is used when the analyte is found in the associated blank as well as in the sample. It indicates possible/probable blank contamination.

$\mathbf{E}=$ Indicates that the compound was detected beyond the calibration range and was subsequently analyzed at a dilution.

$\mathbf{I}=\quad$ Interference.

$.1=$ Indicates an interference on one analytical column only. Result is reported from remaining analytical column.

\section{ABBREVIATIONS}

BS = Indicates blank spike in which reagent grade water is spiked with the CLP matrix spiking solutions and carried through all the steps in the method. Spike recoveries are reported.

$\mathrm{BSD}=$ Indicates blank spike duplicate.

MS $\quad=\quad$ Indicates matrix spike.

MSD = Indicates matrix spike duplicate.

DL = Indicates that recoveries were not obtained because the extract had to be diluted for analysis.

NA $=\quad$ Not Applicable.

DF $=$ Dilution Factor.

$\mathrm{NR}=\quad$ Not Required.

NS $\quad=\quad$ Not Spiked.

SP $\quad=\quad$ Indicates Spiked Compound.

$\mathrm{P}=\quad$ This flag is used for an PESTICIDE/PCB target analyte when there is greater than $25 \%$ difference for detected concentrations between the two GC columns (see Form X). The lower of the two values is reported on Form I and flagged with a "P".

D = This flag identifies all compounds identified in an analysis at a secondary dilution factor.

C $=$ This flag applies to a compound that has been confirmed by GCMS.

NPM $=\quad$ No pattern match for multi-component target analytes. 


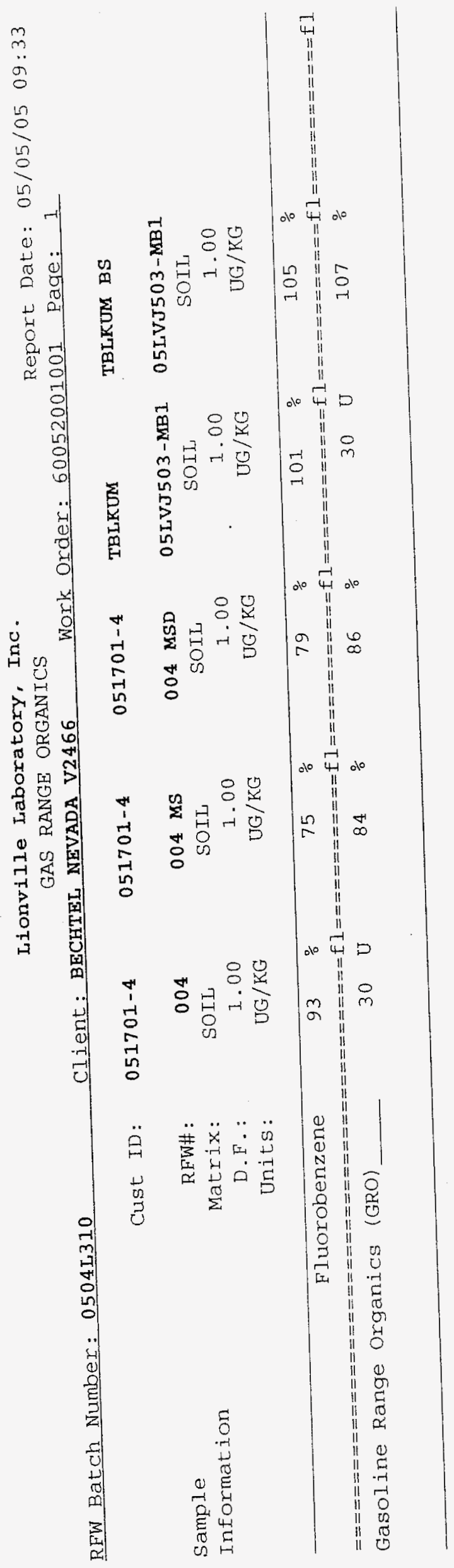

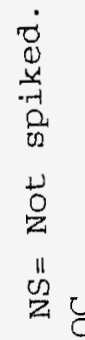

ช

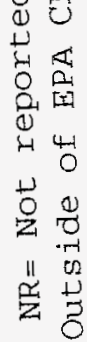

莙 *

영

$5 \frac{0}{0}$

茬

o

क्ष

11

i.

말

$\rightarrow$

동

感 (1)

$3 \stackrel{5}{H}$

वै

崩

क्ष 8

13

.

गु

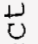

1

0 के

至

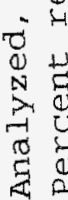

Ð 
Client : BECHTEL NEVADA V2466

LVLH: 0504L310
W.O.\# : 60052-001-001-0001-00

Date Received : 04-26-05

\section{SW846 METALS}

1. This narrative covers the analyses of 3 TCLP leachate samples.

2. The samples were prepared and analyzed in accordance with SW-846 protocol and reported with a CLP deliverable. All samples were analyzed with 6-fold dilutions for ICP metals due to sample matrix. Sample 051701-3 was digested with a 3-fold dilution for $\mathrm{Hg}$ after the sample did not maintain purple color from Potassium Permanganate addition for the required 15 minutes.

3. ICVs, CCVs, and LCSs stock standards were purchased from Inorganic Ventures Laboratory and High Purity.

4. All analyses were performed within the required holding times.

5. All results presented in this report are derived from samples that met LvLI's sample acceptance policy.

6. All Initial and Continuing Calibration Verifications (ICV/CCVs) were within control limits.

7. All Initial and Continuing Calibration Blanks (ICB/CCBs) were within method criteria.

8. All preparation/method blanks were within method criteria. Refer to form 3.

9. All ICP Interference Check Standards were within control limits. Refer to form 4.

10. All laboratory control samples (LCS) were within the $80-120 \%$ control limits. Refer to form 7.

11. All serial dilution percent differences were within SW-846 control limits. Refer to form 9 .

12. The duplicate analysis for Mercury was within the $20 \%$ Relative Percent Difference (RPD) control limits. Refer to form 6 .

13. The TCLP extract from sample 051701-2 was selected for the matrix spike (MS) for this analytical batch. 
The MS recoveries for all analytes in the ICLP extract were above 50\% except for Silver $(5.5 \%)$. The result in the TCLP Leachate was below $80-120 \%$ of the action level so standard addition was not required per Federal Register, Vol.57, No.227, Nov. 24, 1992, page 55117.

14. All sample $\mathrm{D}$ s were changed to accommodate the EPA naming convention which allows a maximum of 6 characters on all CLP Forms. Refer to the comments section of form 1 for the original ID.

15. Recoveries on the Laboratory Summary Report and CLP forms will vary depending on the number of significant figures used in the recovery calculation.

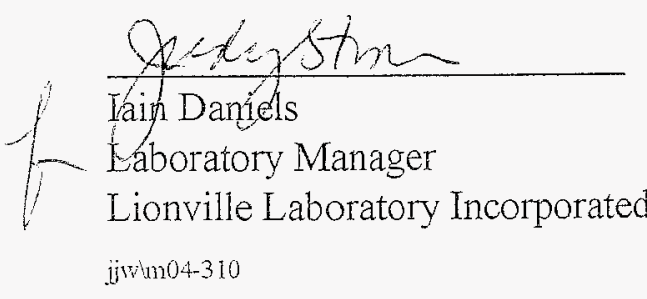

$\frac{5 / 00 / 05}{\text { Date }}$ 


\section{METHOD REFERENCES AND DATA QUALIFIERS}

\section{DATA QUALIFIERS}

$\mathrm{U}=$ Indicates that the parameter was not detected at or above the reported limit. The associated numerical value is the sample detection limit.

$\mathrm{B}=$ Indicates that the parameter was between the Instrument Detection Limit (IDL) and the Contract Required Detection Limit (CRDL)

\section{Q QUALIFIERS}

$E=$ The reported value is estimated because of the presence of interference.

$M=$ Duplicate injection precision not met.

$N=$ Spiked sample recovery not within control limits.

$S=\quad$ The reported value was determined by the Method of Standard Additions (MSA).

$\mathrm{W}=$ Post Digestion spike for Furnace AA analysis is out of control limits (85-115\%), while sample absorbance is less than $50 \%$ of spike absorbance.

* = Duplicate analysis not within control limits.

$+=$ Correlation coefficient for the MSA is less than 0.995 .

\section{ABBREVIATIONS}

$\mathrm{PB}=$ Method or Preparation Blank.

$S=$ Matrix Spike.

$\mathrm{T}=$ Matrix Spike Duplicate.

$\mathrm{R}$ or $\mathrm{D}=$ Sample Replicate

\section{ANALYTICAL METAL METHODS}

1. Not included in the method element list.

2. Modified $\mathrm{Hg}$ : $\mathrm{Hg} 1$ and $\mathrm{Hg} 2$ require less total volume of digestate due to the autosampler analysis. Sample volumes and reagents for mercury determinations in water and soil have been proportionately scaled down to adapt to this semiautomated technique. The sample volume used for water analysis is $33 \mathrm{~mL}$. For soils, approximately 0.3 grams of sample is taken to a final volume of $50 \mathrm{~mL}$ (including all reagents).

3. Flame AA.

4. Graphite Furnace AA.

RFW 21-21L-033/0-01/97 
CIIENT: BECHTEL NEVADA V2466

WORK ORDER: 60052-001-001-0001-00

\begin{tabular}{|c|c|c|}
\hline SAMPLE & STTE ID & ANALYTE \\
\hline$z== \pm===$ & 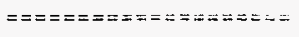 & 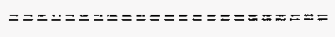 \\
\hline-005 & $051701-1$ & $\begin{array}{l}\text { Bilver, TCLE Leachate } \\
\text { Arseric, TCLE Leachate } \\
\text { Barium, TCLP Leachate } \\
\text { Cadmium, TCL? Leachate } \\
\text { Chromium, TCLE Leachate } \\
\text { Mercury, TCLP Leachate } \\
\text { Lead, TCLP Leachate } \\
\text { Selenium, TCLE Leachate }\end{array}$ \\
\hline
\end{tabular}

$-006 \quad 051701-2$

$-007 \quad 051701-3$
LVL LOT \# : 0504L310

\begin{tabular}{|c|c|c|c|c|}
\hline & & & REPOR'TING & DILUTION \\
\hline RESULT & & UNITS & LIMIT & EACTOR \\
\hline$==m===$ = & & $=== \pm==$ & 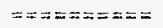 & $==\Sigma===\approx=$ \\
\hline 3.0 & $\mathrm{u}$ & $\mathrm{UG} / \mathrm{L}$ & 3.0 & 6.0 \\
\hline 17.4 & u. & UG $/ \mathrm{L}$ & 17.4 & 6.0 \\
\hline 174 & & UG $/ L$ & 1.2 & 6.0 \\
\hline 2.4 & $\mathrm{u}$ & $\mathrm{UG} / \mathrm{I}$ & 2.4 & 6.0 \\
\hline 6.2 & & $U G / L$ & 2.4 & 6.0 \\
\hline 0.10 & $\mathrm{u}$ & $\mathrm{UG} / \mathrm{L}$ & 0.10 & 1.0 \\
\hline 22.3 & & $\mathrm{UG} / \mathrm{L}$ & 11.4 & 6.0 \\
\hline 24.0 & $u$ & $\mathrm{UG} / \mathrm{L}$ & 24.0 & 6.0 \\
\hline 3.0 & $\mathrm{u}$ & $\mathrm{UG} / \mathrm{L}$ & 3.0 & 6.0 \\
\hline 17.4 & $u$ & UG/L & 17.4 & 6.0 \\
\hline 143 & & UG/L & 1.2 & 6.0 \\
\hline 2.4 & $\mathrm{u}$ & UG $/ \mathrm{L}$ & 2.4 & 6.0 \\
\hline 5.1 & & $\mathrm{UG} / \mathrm{L}$ & 2,4 & 6.0 \\
\hline 0.20 & $\mathrm{u}$ & $\mathrm{UG} / \mathrm{L}$ & 0.10 & 1.0 \\
\hline 22.1 & & UG $/ \mathrm{L}$ & 21.4 & 6.0 \\
\hline 24.0 & $\mathrm{u}$ & $U G / L$ & 24.0 & 6.0 \\
\hline 3.0 & $\mathrm{u}$ & UG $/ L$ & 3.0 & 6.0 \\
\hline 29.1 & & $\mathrm{UG} / \mathrm{L}$ & 27.4 & 6.0 \\
\hline 507 & & UG/工 & 1.2 & 6.0 \\
\hline 2.4 & $\mathrm{u}$ & UG/L & 2.4 & 6.0 \\
\hline 24.1 & & UG / L & 2.7 & 6.0 \\
\hline 0.30 & $\mathrm{u}$ & $\mathrm{UG} / \mathrm{L}$ & 0.30 & 3,0 \\
\hline 55.1 & & UG/L & 11.4 & 6.0 \\
\hline 24.0 & u & $\mathrm{UG} / \mathrm{L}$ & 24.0 & 6.0 \\
\hline
\end{tabular}


CLIENT: BECHTEL NEVADA V246E

WORK ORDER: 60052-001-001-0001-00

$\begin{array}{ll}\text { SAMLLE } & \text { SITE ID } \\ ====== & ================= \\ \text { BLANK1 } & 05 \text { L0224-MBI }\end{array}$

BLANK2 05LO224-MB2

$\begin{array}{ll}\text { BLANK1 } & 05 \mathrm{C} 0090-\mathrm{MB} 1 \\ \text { BLANIK2 } & 05 \mathrm{C0} 090-\mathrm{MB2} \\ \text { BLANK3 } & 05 \mathrm{CO} 090-\mathrm{MB3} \\ \text { BLANK4 } & 05 \mathrm{CO} 090-\mathrm{MB} 4\end{array}$

ANALYTE

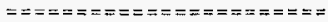

Silver, TCLP Leachate

Arsenic, TCLP Leachate

Barium, TClp Leachate

Cadmium, TCLF Leachate

Chromium, TCLE Leachate

Lead, TCLE Leachate

Selenium, TCLP Leachate

Silver, TCIP Leachate

Arnenic, TCLP Leachate

Barium, TCLP Leachate

Cadmiun, TCLF Leachate

Chromium, IICLP Leachate

Lead, TCL? Leachate

selenium, tCLP Leachate

Mercury, Total

Mercury, TCLP Leachate

Hercury, TCLI Leachate

Vexcury, TCLP Leachate
LVL LOI \#

\begin{tabular}{|c|c|c|c|c|}
\hline & & & REPORTING & DILUTION \\
\hline RESULT & & UNITS & LIMIT & FACTOR \\
\hline$== \pm===$ & & $===\pi==$ & 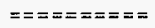 & $= \pm \approx==\leq=\leq$ \\
\hline 0.50 & $u$ & UG/L & 0.50 & 1.0 \\
\hline 2.9 & $u$ & $U G / L$ & 2.9 & 1.0 \\
\hline 1.5 & & $\mathrm{UG} / \mathrm{L}$ & 0.20 & 1.0 \\
\hline 0.40 & $u$ & $\mathrm{UG} / \mathrm{L}$. & 0.40 & 1.0 \\
\hline 0.65 & & UG/L & 0.40 & 1.0 \\
\hline 2.9 & $u$ & $\mathrm{UG} / \mathrm{L}$ & 1.9 & 1.0 \\
\hline 4.0 & u & $\mathrm{UG} / \mathrm{L}$ & 4.0 & 1.0 \\
\hline 3.0 & $u$ & $\mathrm{UG} / \mathrm{L}$ & 3.0 & 6.0 \\
\hline 17.4 & u & $\mathrm{UG} / \mathrm{L}$ & 17.4 & 6.0 \\
\hline 1.8 & & $U G / L$ & 1.2 & 6.0 \\
\hline 2.4 & $u$ & $U G / L$ & 2.4 & 6.0 \\
\hline 2.5 & & $U G / L$ & 2.4 & 6.0 \\
\hline 11.4 & $u$ & UG / L & 11.4 & 6.0 \\
\hline 21.0 & $\mathrm{u}$ & UG $/ \mathrm{L}$ & 24.0 & 5.0 \\
\hline
\end{tabular}

$0.20 \mathrm{UL} \quad \mathrm{UG} / \mathrm{L}$

0.10

1.0

$0.10 \mathrm{U}$ UGG $/ \mathrm{L}$

0.10

1.0

0.10 บ UG/L

0.10

1.0

0.10 u UG/L

0.10 


\section{Case Narrative}

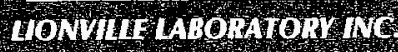

Client: BECHTEL-NEVADA V2466

LVL \#:0504L310
W.O. \#: 60052-001-001-0001-00

Date Received: 04-26-2005

\section{PCB}

Three (3) soil samples were collected on 04-21-2005.

The samples and their associated QC samples were extracted on 04-26-2005 and analyzed according to Lionville Laboratory SOPs on 04-28-2005. The extraction procedure was based on method 3540 C and the extracts were analyzed based on method 8082 .

The following is a summary of the $\mathrm{QC}$ results accompanying the sample results and a description of any problems encountered during their analyses:

1. All results presented in this report are derived from samples that met LVLI's sample acceptance policy.

2. The required holding time for extraction and analysis was met.

3. Samples and their associated QC samples received Copper-Sulfur and Sulfuric Acid cleanups according to Lionville Laboratory SOPs based on SW846 methods 3660A and 3665A respectively.

4. The method blank was below the reporting limits for all target compounds.

5. All surrogate recoveries were within acceptance criteria.

6. The blank spike recoveries were within acceptance criteria.

7. Sample 051701-03 was reported on a wet-weight basis due insufficient sample volume for $\%$ solid analysis. A copy of the Sample Discrepancy Report (SDR) has been enclosed.

8. The initial calibration associated with this data set was within acceptance criteria.

9. The continuing calibration standard analyzed prior to sample extract was within acceptance criteria.

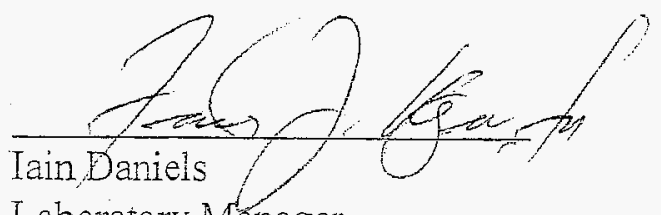

Laboratory Manager

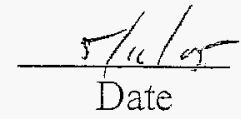

Lionville Laboratory Incorporated

somir:igroupldatalpestbechrell0504-310.pcb 


\section{GLOSSARY OF DATA}

\section{DATA QUALIFIERS}

$\mathbf{U}=$ Indicates that the compound was analyzed for but not detected. The minimum detection limit for the sample (not the method detection limit) is reported with the $U$ (e.g., 10U).

$\mathbf{J}=\quad$ Indicates an estimated value. This flag is used in cases where a target analyte is detected at a level less than the lower quantification level. If the limit of quantification is $10 \mathrm{ug} / \mathrm{L}$ and a concentration of $3 \mathrm{ug} / \mathrm{L}$ is calculated, it is reported as $3 \mathrm{~J}$.

B = This flag is used when the analyte is found in the associated blank as well as in the sample. It indicates possible/probable blank contamination.

$\mathbf{E}=$ Indicates that the compound was detected beyond the calibration range and was subsequently analyzed at a dilution.

I $=$ Interference.

$.1=$ Indicates an interference on one analytical column only. Result is reported from remaining analytical column.

\section{ABBREVIATIONS}

BS = Indicates blank spike in which reagent grade water is spiked with the CLP matrix spiking solutions and carried through all the steps in the method. Spike recoveries are reported.

BSD $=$ Indicates blank spike duplicate.

MS $\quad=\quad$ Indicates matrix spike.

MSD = Indicates matrix spike duplicate.

DL = Indicates that recoveries were not obtained because the extract had to be diluted for analysis.

NA $=$ Not Applicable.

DF $\quad=\quad$ Dilution Factor.

$\mathrm{NR}=$ Not Required.

NS $\quad=\quad$ Not Spiked.

SP $\quad=\quad$ Indicates Spiked Compound.

$P=\quad=\quad$ This flag is used for an PESTICIDE/PCB target analyte when there is greater than $25 \%$ difference for detected concentrations between the two GC columns (see Form X). The lower of the two values is reported on Form I and flagged with a "P".

D $=$ This flag identifies all compounds identified in an analysis at a secondary dilution factor.

$\mathrm{C}=$ This flag applies to a compound that has been confirmed by GC/MS.

NPM $=\quad$ No pattern match for multi-component target analytes. 


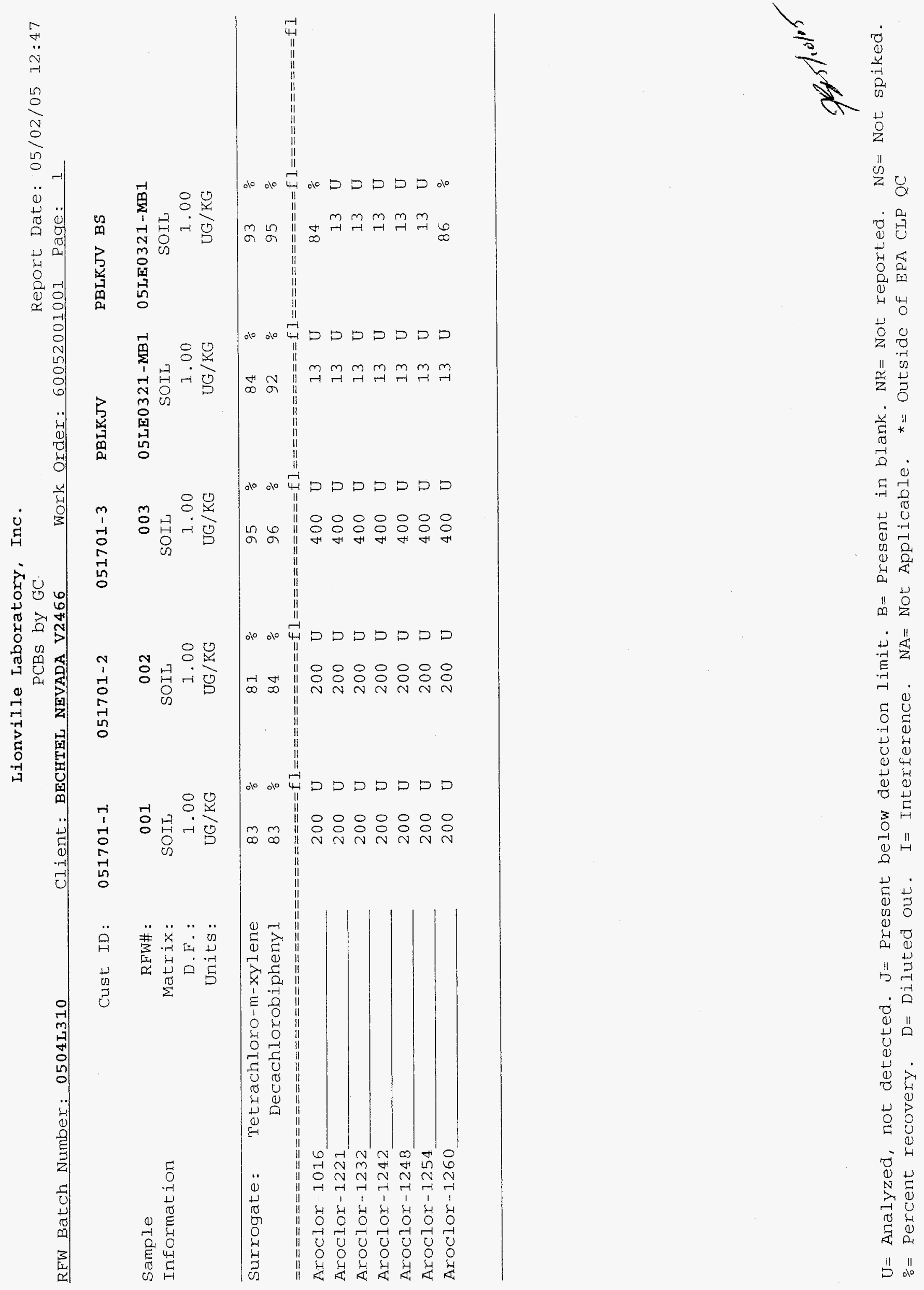


Closure Report - CAU 140

Section: Appendix E

Revision: 0

Date: August 2005

\section{APPENDIX E}

\section{WASTE DISPOSITION DOCUMENTATION}


Closure Report - CAU 140

Section: Appendix E

Revision: 0

Date: August 2005

THIS PAGE INTENTIONALLY LEFT BLANK 
For waste characterization, approval, andlor assistance, contact Solid Waste Operation (SWO) at 5-7898.

\section{REQUIRED: WASTE GENERATOR INFORMATION}

(This form is for rolloffs, dump trucks, and other onsite disposal of materials.)

Waste Generator: BN Environmental Restoration-Reed Poderis Phone Number: $\underline{7-0847}$

Location / Origin: CAU 140 CAS 05-08-01

\begin{tabular}{|c|c|c|c|c|}
\hline Waste Category: (check one) & $\square$ & Commercial & X Industrial & \\
\hline Waste Type: & $\square$ & Putrescible & X FFACO-onsite & $\square$ WAC Exception \\
\hline$\square$ Non-Putrescible & $\square$ & Asbestos Containing Material & FFACO-offsite & $\square$ Historic DOE/NV \\
\hline Pollution Prevention Category: (check one) & $x$ & Environmental management & $\square$ Defense Projects & \\
\hline Pollution Prevention Category: (check one) & $\bar{X}$ & Clean-Up & $\square$ Routine & \\
\hline Method of Characterization: (check one) & $x$ & Sampling \& Analysis & $\square$ Process Knowledge & $\square$ Contents \\
\hline
\end{tabular}

at all three NTS landfills: wastes (needles, sharps, bloody clothing).

Additional Prohibited Waste Sewage Sludge; Animal carcasses-, Wet garbage (food waste); and Friable asbestos at the Area 9 U10c Landfill:

\section{REQUIRED: WASTE CONTENTS ALLOWABLE WASTES}

Check all allowable wastes that are contained within this load:

NOTE: Waste disposed at the Area 6 Hydrocarbon Landfill must have come into contact with petroleum hydrocarbons or coolants such as: gasoline (no benzene, lead); jet fuel; diesel fuel; lubricants and hydraulics; kerosene; asphaltic petroleum hydrocarbon; and ethylene glycol.
Acceptable waste at any NTS landfill:
$\square$ Asphalt
[X] Metal
[X] Wood
$\square$ Paper
$\square$ Rocks / unaltered geologic materials
X] Empty containers
[X] Plastic
[X] Wire
X Cable
X] Soil
$\square$ Rubber (excluding tires)
X] Demolition debris

$[\mathbf{X}$ Manufactured items: (swamp coolers, furniture, rugs, carpet, electronic components, PPE, etc.)

Additional waste accepted at the Area 23 Mercury Landfill: $\square$ Office waste $\square$ Food Waste $\square$ Animal Carcasses

Asbestos: $\square$ Friable $\square$ Non-Friable (contact SWO if regulated load) Quantity:

Additional waste accepted at the Area 9 U10c Landfill:
$\square$ Non-friable asbestos
$\square$ Drained automobiles and military vehicles
$\square$ Light ballasts (contact SWO)
$\square$ Drained fuel filters (gas \& diesel)
Solid fractions from sand/oil/water separators
Hydrocarbons (contact SWO)
$\square$ Deconned Underground and Above Ground
Tanks

Additional waste accepted at the Area 6 Hydrocarbon Landfill:
$\square$ Septic sludge $\square$ Rags
$\square$ Drained fuel filters (gas \& diesel)
$\square$ Plants
$\square$ Sludge from sand/oil/water separators
Crushed non-terne plated oil filters REQUIRED: WASTE GENERATOR SIGNATURE

Initials: (If initialed, no radiological clearance is necessary.)

The above mentioned waste was generated outside of a Controlled Waste Management Area (CWMA) and to the best of my knowledge, does not contain radiological materials.

To the best of my knowledge, the waste described above contains only those $n$ site. I have verified this through the waste characterization method identified at prohibited and allowable waste items.

Print Name: Reed J. Poderis (BN ER)
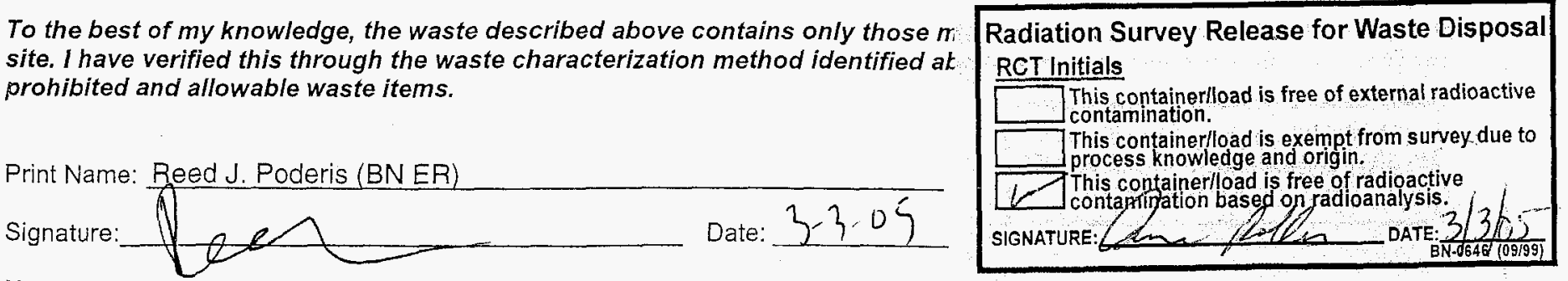

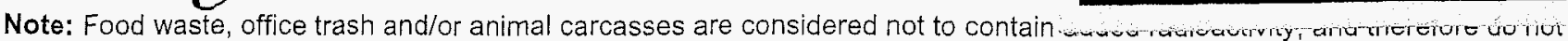
require a radiological clearance.

SWO USE ONLY

Load Weight (net from scale or estimate):

Signature of Certifier

sectecto

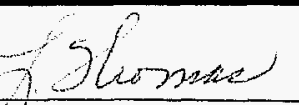


(Waste definitions are avallable on page 2)

\begin{tabular}{lllll}
\hline SWO USE (Circle One Area) AREA & 23 & 6 & 9 & LANDFIL.
\end{tabular}

For waste characterization, approval, and/or assistance, contact Solid Waste Operation (SWO) at 5-7898.

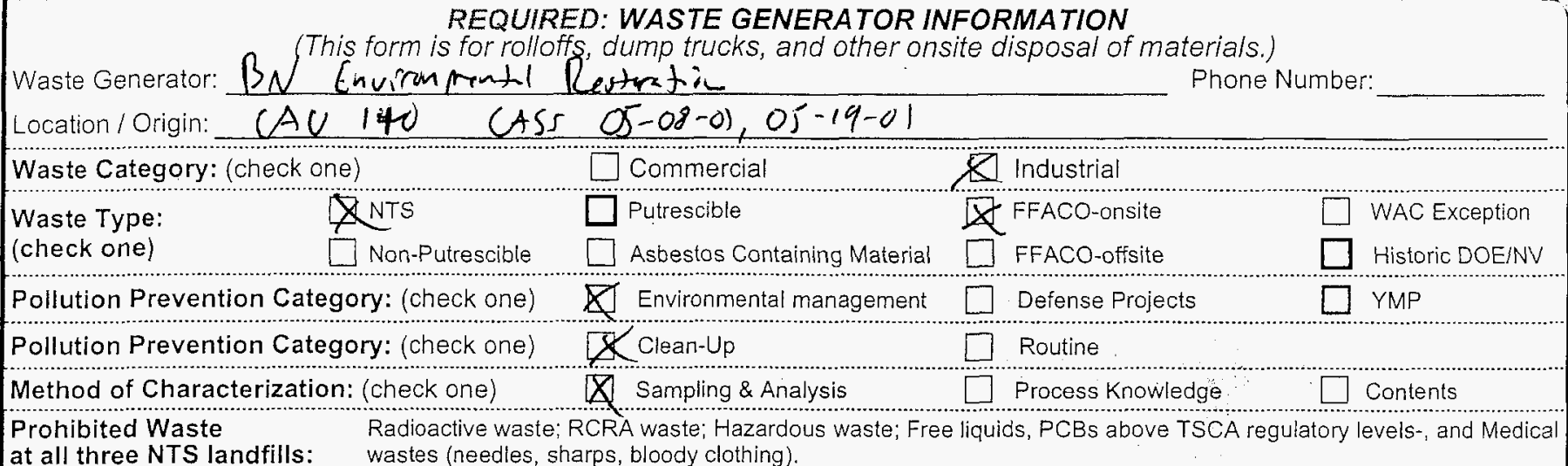
at all three NTS landfills: $\quad$ wastes (needles, sharps, bloody clothing).

Additional Prohibited Waste Sewage Sludge; Animal carcasses-, Wet garbage (food waste); and Friable asbestos at the Area 9 U10c Landfill:

REQUIRED: WASTE CONTENTS ALLOWABLE WASTES

Check all allowable wastes that are contained within this load:

NOTE: Waste disposed at the Area 6 Hydrocarbon Landfill must have come into contact with petroleum hydrocarbons or coolants such as: gasoline (no benzene, lead); jet fuel; diesel fuel; lubricants and hydraulics; kerosene; asphaltic petroleum hydrocarbon; and ethylene glycol.

Acceptable waste at any NTS landfill $\quad \square$ Paper $\quad \square$ Rocks / unaltered geologic materials

$\square$ Asphalt $\quad \square$ Metal $\square$ Wood $\square$ Soil $\square$ Rubber (excluding tires)

$\not$ Plastic $\bigotimes$ Wire $\not$ Cable $\not$ Cloth $\quad \square$ insulation (non-Asbestosform)

D.Manufactured items: (swamp coolers, furniture, rugs, carpet, electronic components, PPE, etc.)

Additional waste accepted at the Area 23 Mercury Landfill: $\square$ Office waste $\square$ Food Waste $\square$ Animal Carcasses

$\square$ Asbestos: $\square$ Friable $\square$ Non-Friable (contact SWO if regulated load) Quantity:

Additional waste accepted at the Area 9 U10c Landfill:
$\square$ Non-friable asbestos
$\square$ Drained automobiles and military vehicles
Solid fractions from sand/oil/water separators
$\square$ Light ballasts (contact SWO)
$\square$ Drained fuel filters (gas \& diesel)
Deconned Underground and Above Ground
$\square$ Hydrocarbons (contact SWO)
$\square$ Other
Tanks
Additional waste accepted at the Area 6 Hydrocarbon Landfill:
$\square$ Septic sludge $\square$ Rags
$\square$ Drained fuel filters (gas \& diesel)
[Plants
$\square$ Soil
$\square$ sludge from sand/oil/water separators
Other
Crushed non-terne plated oil filters
REQUIRED: WASTE GENERATOR SIGNATURE

Initials:

(If initialed, no radiological clearance is necessary.)

The above mentioned waste was generated outside of a Controlled Waste $M i$ knowledge, does not contain radiological materials.

To the best of my knowledge, the waste described above contains only thos site. I have verified this through the waste characterization method identifiec prohibited and allowable waste items.

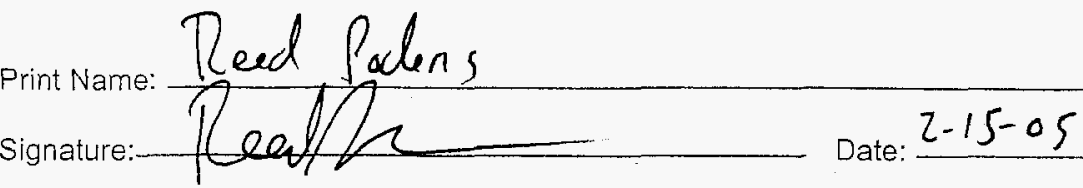

Radiation Survey Release for Waste Disposal RCT Initials

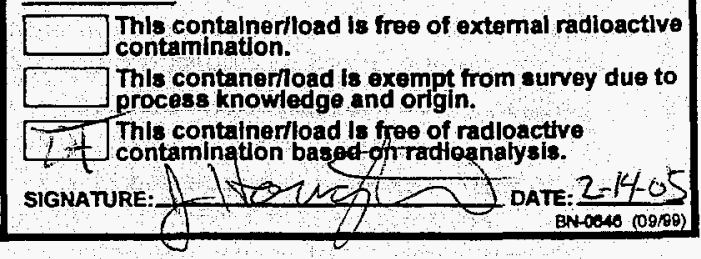

Note: Food waste, office trash and/or animal carcasses are considered not to contain added radioactivity, and therefore do not require a radiological clearance.

SWO USE ONLY

Load Weight (net from scale or estimate) 14,320

Signature of Certifier:

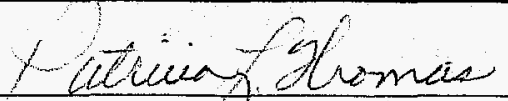


(Waste definitions are available on page 2)

\begin{tabular}{lllllll}
\hline SWO USE (Circle One Area) AREA & 23 & 6 & 9 & LANDFILL
\end{tabular}

For waste characterization, approval, and/or assistance, contact Solid Waste Operation (SWO) at 5-7898.

$$
\text { REQUIRED: WASTE GENERATOR INFORMATION }
$$

Waste Generator: $B N$ (This form is for rolloffs, dump trud

Location / Origin: CAV 140 CAS 05-99-07, 05-19-01,05-08-01

Waste Category: (check one) $\square$ Commercial $\quad$ Industrial

Waste Type: $\quad$ NTS $\square$ Putrescible

(check one) $\square$ Non-Putrescible $\square$ Asbestos Containing Material

Pollution Prevention Category: (check one)

D Environmental management

A FFACO-onsite

FFACO-Offsite

Phone Number:

Pollution Prevention Category: (check one)

Method of Characterization: (check one)

Clean-Up

10 Sampling \& Analysis

$\square$ Defense Projects

$\square$ Routine

Prohibited Waste $\quad$ Radioactive waste; RCRA waste; Hazardous waste; Free liquids, PCBs above TSCA regulatory levels-, and Medical at all three NTS landfills: $\quad$ wastes (needles, sharps, bloody clothing).

Additional Prohibited Waste Sewage Sludge; Animal carcasses-, Wet garbage (food waste); and Friable asbestos at the Area 9 U10c Landfill:

\section{REQUIRED: WASTE CONTENTS ALLOWABLE WASTES}

Check all allowable wastes that are contained within this load:

NOTE: Waste disposed at the Area 6 Hydrocarbon Landfill must have come into contact with petroleum hydrocarbons or coolants such as: gasoline (no benzene, lead); jet fuel; diesel fuel; lubricants and hydraulics; kerosene; asphaltic petroleum hydrocarbon; and ethylene glycol. Acceptable waste at any NTS landfill: $\square$ Paper \ Rocks/ unaltered geologic materials $\quad$ D Empty containers

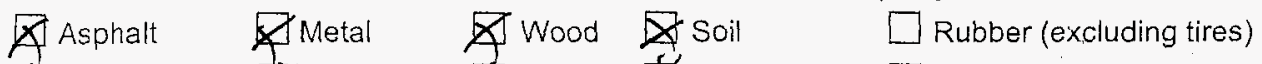

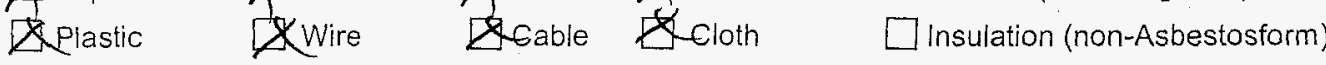

X Manufactured items: (swamp coolers, furniture, rugs, carpet, electronic components, PPE, etc.)

Additional waste accepted at the Area 23 Mercury Landfill: $\square$ Office waste $\square$ Food Waste $\square$ Animal Carcasses

$\square$ Asbestos: $\square$ Friable $\square$ Non-Friable (contact SWO if regulated load) Quantity:

Additional waste accepted at the Area 9 U10c Landfill:
$\square$ Non-friable asbestos
$\square$ Drained automobiles and military vehicles
Solid fractions from sand/oil/water separators
$\square$ Light ballasts (contact SWO)
Drained fuel filters (gas \& diesel)
$\square$ Deconned Underground and Above Ground
Hydrocarbons (contact SWO)
Other
Additional waste accepted at the Area 6 Hydrocarbon Landfill:

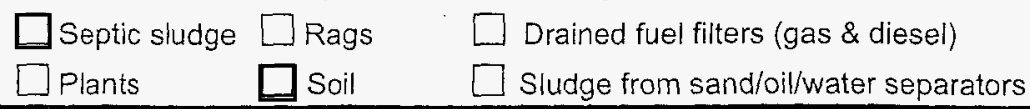
$\square$ Tanks
REQUIRED: WASTE GENERATOR SIGNATURE
Initials:
(If initialed, no radiological clearance is necessary.)

The above mentioned waste was generated outside of a Controlled Waste $M$

knowledge, does not contain radiological materials.

To the best of my knowledge, the waste described above contains only thos site. I have verified this through the waste characterization method identifie prohibited and allowable waste items.

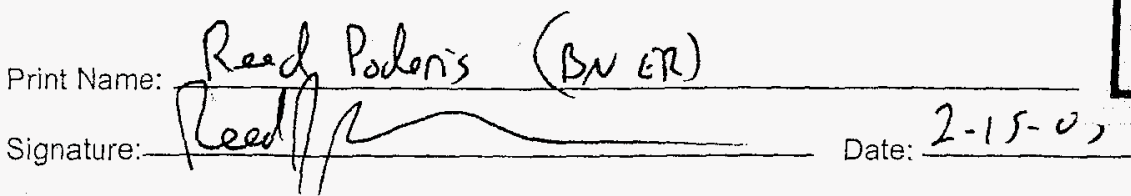

Radiation Survey Release for Waste Disposal RCT Initials

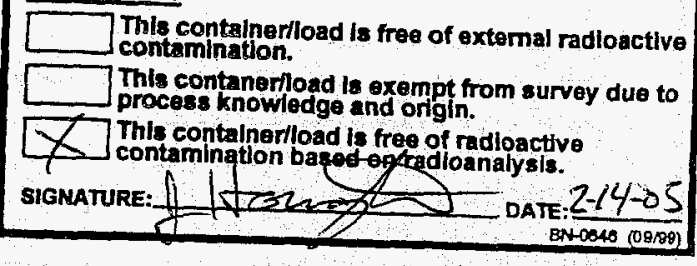

Note: Food waste, office trash and/or animal carcasses are considered not to contain added radioactivity, and therefore do not require a radiological clearance.

SWO USE ONLY

Load Weight (net from scale ér estimate) 29,500 signature of Certifier: thuith thmu 
(Waste definitions are available on page 2)

$\begin{array}{llllll}\text { SWO USE (Circle One Area) AREA } & 23 & 6 & & \text { LANDFILL }\end{array}$

For waste characterization, approval, andlor assistance, contact Solid Waste Operation (SWO) at 5-7898.

\section{REQUIRED: WASTE GENERATOR INFORMATION}

(This form is for rolloffs, dump trucks, and other onsite disposal of materials.)

Waste Generator: BN Environmental Restoration - Reed Poderis

Phone Number: 7-0847

Location / Origin: CAU 140 CASs 05-23-01, 05-08-02, 05-19-01, 23-17-01

Method of Characterization: (check one) $\quad[X]$ Sampling \& Analysis $\square$ Process Knowledge $\square$ Contents

Prohibited Waste Radioactive waste; RCRA waste; Hazardous waste; Free liquids, PCBs above TSCA regulatory levels-, and Medical at all three NTS landfills: $\quad$ wastes (needles, sharps, bloody clothing)

Additional Prohibited Waste Sewage Sludge; Animal carcasses-, Wet garbage (food waste); and Friable asbestos at the Area 9 U10c Landfill:

REQUIRED: WASTE CONTENTS ALLOWABLE WASTES

Check all allowable wastes that are contained within this load:

NOTE: Waste disposed at the Area 6 Hydrocarbon Landfill must have come into contact with petroleum hydrocarbons or coolants such as: gasoline (no benzene, lead); jet fuel; diesel fuel; lubricants and hydraulics; kerosene; asphaltic petroleum hydrocarbon; and ethylene glycol.

Acceptable waste at any NTS landfill: $\square$ Paper $\square$ Rocks / unaltered geologic materials $\quad[\mathbf{X}$ Empty containers

$\square$ Asphalt $\quad \boldsymbol{X}$ Metal $\quad \boldsymbol{X}$ Wood $[\boldsymbol{X}$ Soil $\quad \boldsymbol{X}$ Rubber (excluding tires)

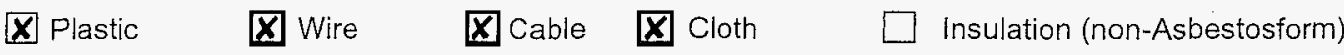

X] Demolition debris

X Manufactured items: (swamp coolers, furniture, rugs, carpet, electronic components, PPE, etc.)

Additional waste accepted at the Area 23 Mercury Landfill: $\square$ Office waste $\square$ Food Waste $\square$ Animal Carcasses

$\square$ Asbestos: $\square$ Friable $\square$ Non-Friable (contact SWO if regulated load) Quantity:

Additional waste accepted at the Area 9 U10c Landfill:
$\square$ Non-friable asbestos
$\square$ Drained automobiles and military vehicles
Solid fractions from sand/oil/water separators
$\square$ Light ballasts (contact SWO)
$\square$ Drained fuel filters (gas \& diesel)
Deconned Underground and Above Ground
$\square$ Hydrocarbons (contact SWO)
Tanks

Additional waste accepted at the Area 6 Hydrocarbon Landfill:
$\square$ Septic sludge $\square$ Rags
Drained fuel filters (gas \& diesel)
Crushed non-terne plated oil filters
$\square$ Plants
Sludge from sand/oil/water separators
PCBs below 50 parts per million

Initials:

REQUIRED: WASTE GENERATOR SIGNATURE

The above mentioned waste was generated outside of a Controlled Waste Management Area (CWMA) and to the best of my knowledge, does not contain radiological materials.

To the best of my knowledge, the waste described above contains only those site. I have verified this through the waste characterization method identified: prohibited and allowable waste items.

Print Name: Reed J. Ppderis (BNER)

Signature:<smiles>CC(C)(C)C12CC3CC(CC(C3)C1)C2</smiles><smiles>C1=CC1</smiles><smiles>C1=CC1</smiles>
Date: $2-15-05$

Note: Food waste, office trash and/or animal carcasses are considered not to conta require a radiological clearance.

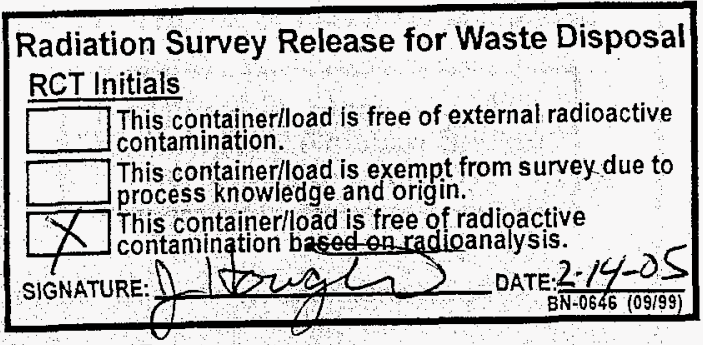

Radiation Survey Release for Waste Disposal This containerload is free of external radioactive contamination This container oad is exempt from survey due to . .

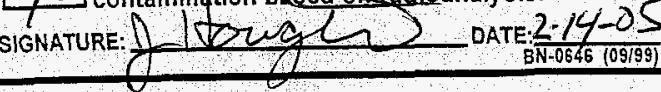

\section{SWO USE ONLY}

Load Weight (net from scale or estimate) 31,500

Signature of Certifier:

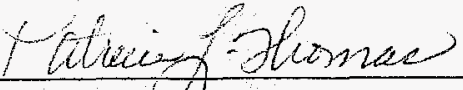


NTS Landfill Load Verification

(Waste definitions are available on page 2)

$\begin{array}{ccccc}\text { SWO USE (Circle One Area) AREA } & 23 & 6 & \text { LANDl. }\end{array}$

REQUIRED: WASTE GENERATOR INFORMATION

(This form is for rolloffs, dump trucks, and other onsite disposal of materials.)

Waste Generator: BN Environmental Restoration - Reed Poderis

Phone Number: 7-0847

Location / Origin: CAU 140 CAS 05-17-01

Waste Category: (check one)

Waste Type:

X] NTS

Commercial

X Industrial

(check one)

$\square$ Non-Putrescible

$\square$ Putrescible

X FFACO-onsite

WAC Exception

Pollution Prevention Category: (check one)

$\square$ Asbestos Containing Materia!

$\square$ FFACO-offsite

Historic DOE/NV

Pollution Prevention Category: (check one)

$\boldsymbol{X}$ Environmental management

Defense Projects

Method of Characterization: (check one)

$\boldsymbol{X}$ Clean-Up

$\square$ Routine

Prohibited Waste Radioactive waste; RCRA waste; Hazardous waste; Free liquids, PCBs above TSCA regulatory levels-, and Medical at all three NTS landfills:

wastes (needles, sharps, bloody clothing)

Additional Prohibited Waste Sewage Sludge; Animal carcasses-, Wet garbage (food waste); and Friable asbestos at the Area 9 U10c Landfill:

\section{REQUIRED: WASTE CONTENTS ALLOWABLE WASTES}

Check all allowable wastes that are contained within this load:

NOTE: Waste disposed at the Area 6 Hydrocarbon Landfill must have come into contact with petroleum hydrocarbons or coolants such as: gasoline (no benzene, lead); jet fuel; diesel fuel; lubricants and hydraulics; kerosene; asphaltic petroleum hydrocarbon; and ethylene glycol.

Acceptable waste at any NTS landfill $\quad \square$ Paper $\square$ Rocks / unaltered geologic materials

$\square$ Asphalt $\quad[\mathbf{X}$ Metal $\quad[\mathbf{X}$ Wood $[\mathbf{X}$ Soil $\square$ Rubber (excluding tires)

$\boldsymbol{X}$ Plastic $\quad \boldsymbol{X}$ Wire $\quad \boldsymbol{X}$ Cable $\mathbf{X}$ Cloth $\square$ insulation (non-Asbestosform)

$[\boldsymbol{X}$ Manufactured items: (swamp coolers, furniture, rugs, carpet, electronic components, PPE, etc.)

Additional waste accepted at the Area 23 Mercury Landfill: $\square$ Office waste $\square$ Food Waste $\square$ Animal Carcasses

$\square$ Asbestos: $\square$ Friable $\square$ Non-Friable (contact $S W O$ if regulated load) Quantity:

Additional waste accepted at the Area 9 U10c Landfill:
$\square$ Non-friable asbestos
$\square$ Drained automobiles and military vehicles
Light ballasts (contact SWO)
Drained fuel filters (gas \& diesel)
Hydrocarbons (contact SWO)
$\square$ Deconned Underground and Above Ground
Additional waste accepted at the Area 6 Hydrocarbon Landfill:
$\square$ Septic sludge $\square$ Rags
$\square$ Plants
$\square$ Drained fuel filters (gas \& diesel)
Sludge from sand/oil/water separators

Solid fractions from sand/oil/water separators

$\mathbf{X}$ Empty containers

X] Demolition debris

X Cement \& concrete REQUIRED: WASTE GENERATOR SIGNATURE

Initials: (If initialed, no radiological clearance is necessary.)

The above mentioned waste was generated outside of a Controlled Waste Management Area (CWMA) and to the best of my knowledge, does not contain radiological materials.

To the best of my knowledge, the waste described above contains only those materials that are allowed for disposal at this site. I have verified this through the waste characterization method identified above and a review of the above-mentioned prohibited and allowable waste items.

Print Name: Reed J. Poderis (BN ER)

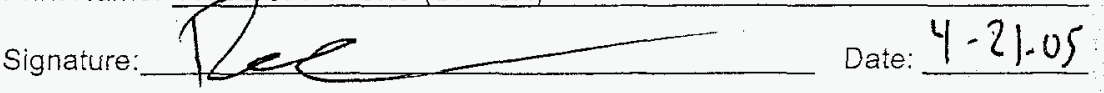

Note: Food waste, office trash and/or animal carcasses are considered not to con require a radiological clearance.

SWO USE ONLY

Load Weight (net from scale or estimate): 100

Signature of Certifier

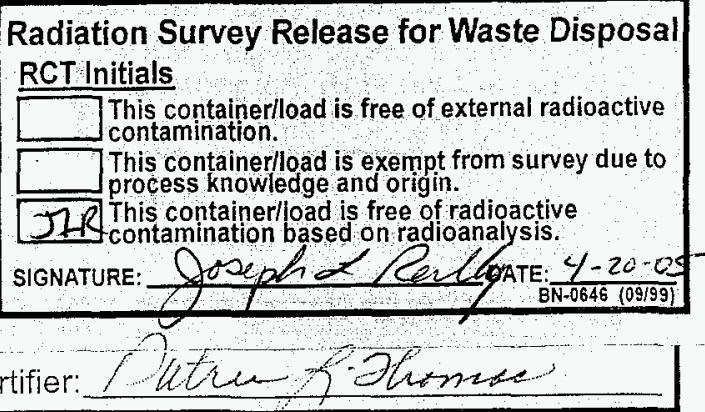

$8 \mathrm{~N}-0918(09 / 00)$ 


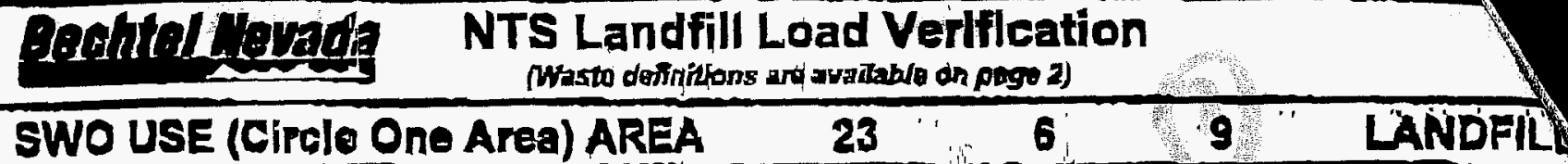

For wasto charattorization, agproval, andror assistance, contect Solid Waste Operation (SWO) al 57898. REOUIREO: WASTE GENERATOR INFOAMATION

This form is tor rollotis, dump (rucks, and other onsite disposal of materials.)

Waste Generator. Fhomw Environmangal Ine.

Phane Number. 52999 Location / Origin: Am:23, CALL Z2, CAS 23-17-09

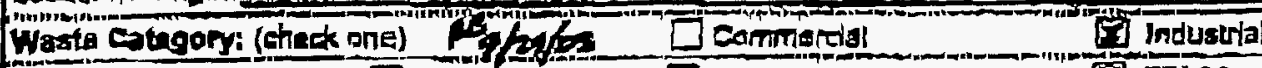

$\square$ NTS $\square$ Putregole

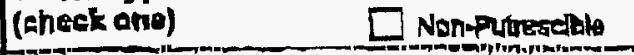

$\square$ sobestos Cantolning Mabsilal

D FFAco-olítite

F] Emirenmanks managomon:

Defiense Projasts

(1) Clopan-Lp

Polutuen Provention Category (chedk one)

Mothed ol Characteint tons (chack one)

F] Samping 2 arioly ic

Rowtine

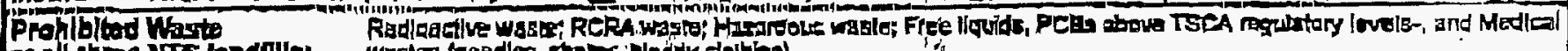

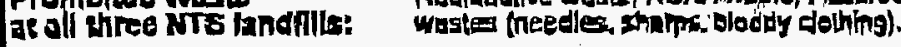

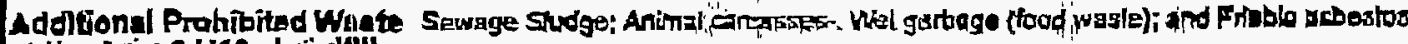
at tho Aria 9 Utoe Lindill:

\section{REQUURED: WASTE CONTENTS ALLOWAGLEWASTES}

Check all allowable wastas ihal are contained whinth this tagd:

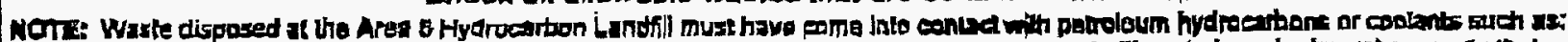

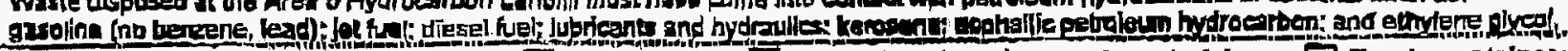

Acceplat Paper
E Asphatt
口 Metri
$\square$ woot
[L] Soil
$\square$ Rubber (excluding tires)
$\square$ Dernolition debris
20 Plastice
$\square$ wire
$\square$ cable $\square$ clech
पInsulation (non-asesstosfom)
$\square$ cement \& conersto

D Manufactured items: (gwamp coolers, furniture, nigs, Gapet, electronio components, PPE, atE)

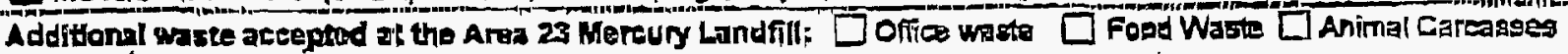

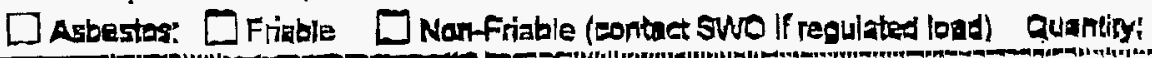

Additional wante accegped ait the Area 9 uque Lundill:
QNonufinbla asbescos
$\square$ Drained autoriobiles and military vehides.'.
$\square$ Light ballests (eankat swo)
$\square$ Drained fuel filrers taza \& diegel\}
Solid fractions from sond/oilwater separotors
Q Hydroeatons (contaed swa)
other
a. Deconned Undstaround and Above Gound
Additonal wate aceoptid at Uhe Area 6 Hydracarbon Landill:
$\square$ septle sluage $\square$ Fiags
$\square$ plonts $\square$ soil
D Drained tuel thiters (gas \& diese?
i
Initials: 15
S sludge from andlaikwater geparators
$\square$ cushed non-ieme plated oil nilters REQUIRED: WASTE GENERATOR SIGNATURE.

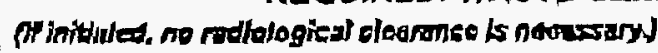

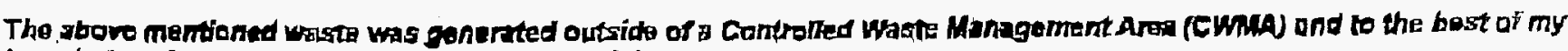
knowledge, deas not contion radiolagical matavits.

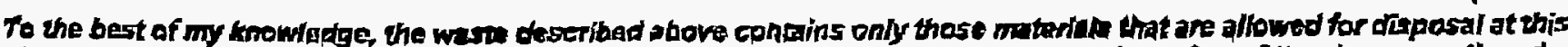

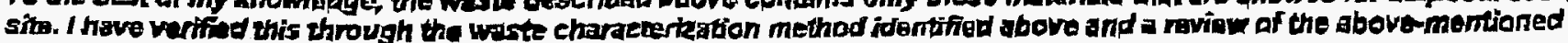
pnohibited and allowible waste thens.

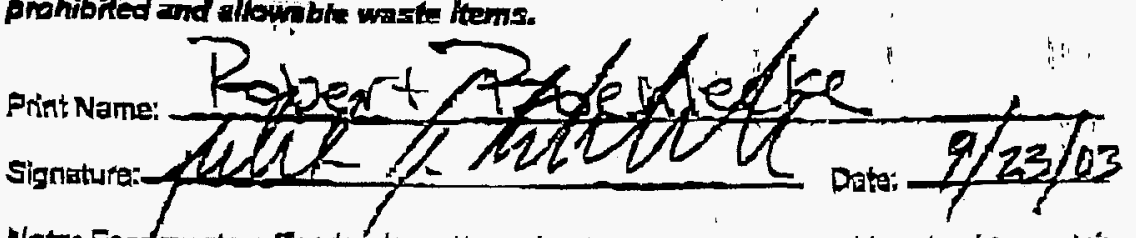

If applieablo, pluce BN-OBAG, "Redlologieal Retarie streker' hore. Onsile uge only.

Notw: Food waste, fille trosh and/or animal oreages are censidered not to contain added radionedivity, and therefore do not requile a radiologigal dearance.

SWO USE ONYY.

Load Wolght (not trom (seale/ar estimata): 500

Signature of Certifier.
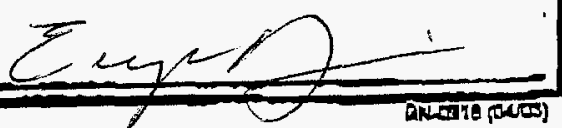


\section{APPENDIX F*}

\section{MODIFICATIONS TO THE POST-CLOSURE PLAN}

*Appendix F, Modifications to the Post-Closure Plan, of the standardized outline for a Federal Facility Agreement and Consent Order Closure Report is not applicable to the closure of CAU 140. No modifications to the plan were required. 
Closure Report - CAU 140

Section: Appendix F

Revision: 0

Date: August 2005

THIS PAGE INTENTIONALLY LEFT BLANK 


\section{APPENDIX G}

\section{USE RESTRICTION DOCUMENTATION}


Closure Report - CAU 140

Section: Appendix G

Revision: 0

Date: August 2005

THIS PAGE INTENTIONALLY LEFT BLANK 


\section{CAU Land-Use Restriction Information}

CAU Number/Description: CAU 140: Waste Dumps, Burn Pits, and Storage Area

Applicable CAS Numbers/Descriptions: CAS 05-23-01, Gravel Gertie

Contact (organization/project): NNSA/NSO Industrial Sites Project Manager

Surveyed Area (NAD 83 Geodetic, decimals): CAS 05-23-01, Gravel Gertie

\begin{tabular}{|c|c|c|}
\hline Fence Points & Northing $(\mathbf{m})$ & Easting $(\mathbf{m})$ \\
\hline \hline Fence Point \#1 & 4069191.283 & 591872.551 \\
\hline Fence Point \#2 & 4069189.852 & 591882.135 \\
\hline Fence Point \#3 & 4069183.145 & 591900.980 \\
\hline Fence Point \#4 & 4069173.065 & 591918.290 \\
\hline Fence Point \#5 & 4069155.437 & 591927.977 \\
\hline Fence Point \#6 & 4069139.960 & 591926.037 \\
\hline Fence Point \#7 & 4069122.760 & 591914.814 \\
\hline Fence Point \#8 & 4069112.689 & 591899.158 \\
\hline Fence Point \#9 & 4069111.515 & 591879.675 \\
\hline Fence Point \#10 & 4069118.270 & 591858.161 \\
\hline Fence Point \#11 & 4069127.880 & 591844.739 \\
\hline Fence Point \#12 & 4069142.511 & 591840.440 \\
\hline Fence Point \#13 & 4069162.856 & 591851.085 \\
\hline Fence Point \#14 & 4069179.297 & 591861.566 \\
\hline
\end{tabular}

Survey Date: $\underline{04 / 12 / 2005}$ Survey Method Transit

Site Monitoring Requirements: Visual Inspections

Required Frequency (quarterly, annually?): Annually

If Monitoring Has Started, Indicate last Completion Date: $\underline{\mathrm{N} / \mathrm{A}}$

\section{Use Restrictions}

The future use of any land related to this Corrective Action Unit (CAU), as described by the above surveyed location, is restricted from any DOE or Air Force activity that may alter or modify the containment control as approved by the state and identified in the CAU Closure Report or other CAU documentation unless appropriate concurrence is obtained in advance.

Comments: See the CAU 140 Closure Report for additional information on the condition of the site and any monitoring and/or inspection requirements.

Submitted By:

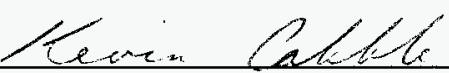

Date: $7-27-65$

Attachments: Site Figure survey locations and coordinates (CAU 140, CAS 05-23-01 UR) 


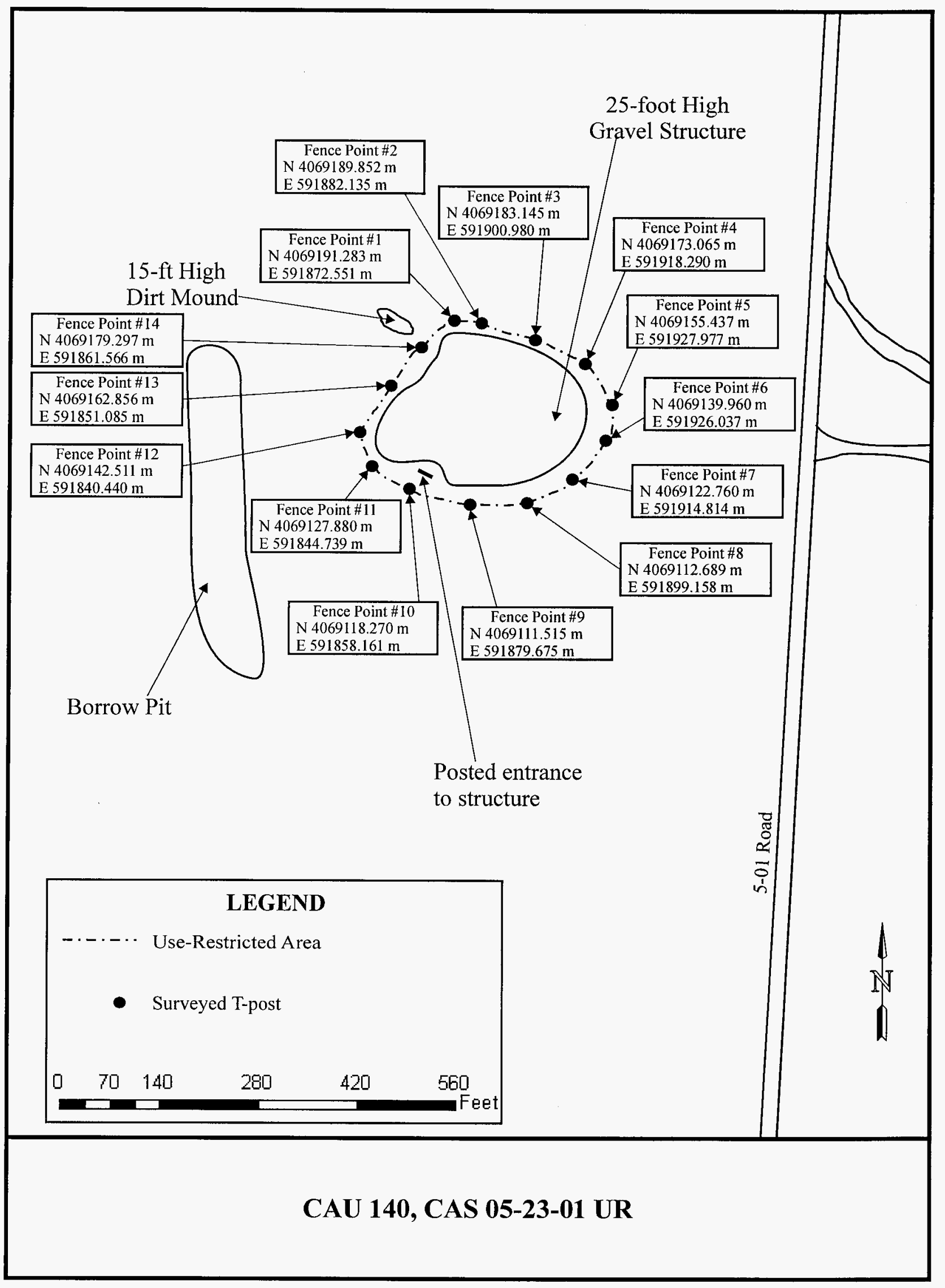




\section{CAU Land-Use Restriction Information}

CAU Number/Description: CAU 140: Waste Dumps, Burn Pits, and Storage Area

Applicable CAS Numbers/Descriptions: CAS 23-17-01, Hazardous Waste Storage Area

Contact (organization/project): $\underline{\text { NSA/NSO Industrial Sites Project Manager }}$

Surveyed Area (NAD 83 Geodetic, decimals): CAS 23-17-01, Hazardous Waste Storage Area

\begin{tabular}{|c|c|c|}
\hline \hline & Landfll Monuments & Easting (m) \\
\hline & Northing $\mathbf{( m )}$ & 588170.842 \\
\hline Fence Corner & 4057415.084 & 588199.911 \\
\hline Monument \#1 & 4057442.835 & 588234.208 \\
\hline Monument \#2 & 4057415.079 & 588265.229 \\
\hline Monument \#3 & 4057390.396 & 588301.116 \\
\hline Monument \#4 & 4057362.765 & 588272.144 \\
\hline Monument \#5 & 4057341.227 & . \\
\hline
\end{tabular}

\begin{tabular}{|c|c|c|}
\hline & TPH-Impacted Area & \\
\hline & Northing $(\mathbf{m})$ & Easting $(\mathbf{m})$ \\
\hline Corner \#1 & 4057483.113 & 588277.959 \\
\hline Corner \#2 & 4057496.550 & 588284.605 \\
\hline Corner \#3 & 4057504.270 & 588272.423 \\
\hline Corner \#4 & 4057490.849 & 588264.615 \\
\hline
\end{tabular}

Survey Date: $\underline{04 / 12 / 2005}$ Survey Method Transit

Site Monitoring Requirements: Visual Inspections

Required Frequency (quarterly, annually?): Annually

If Monitoring Has Started, Indicate last Completion Date: $\underline{\mathrm{N} / \mathrm{A}}$

\section{Use Restrictions}

The future use of any land related to this Corrective Action Unit (CAU), as described by the above surveyed location, is restricted from any DOE or Air Force activity that may alter or modify the containment control as approved by the state and identified in the CAU Closure Report or other CAU documentation unless appropriate concurrence is obtained in advance.

Comments: See the CAU 140 Closure Report for additional information on the condition of the site and any monitoring and/or inspection requirements.

Submitted By:

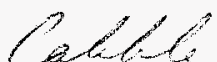

Date:

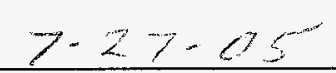

Attachments: Site Figure survey locations and coordinates (CAU 140, CAS 23-14-01 UR) 


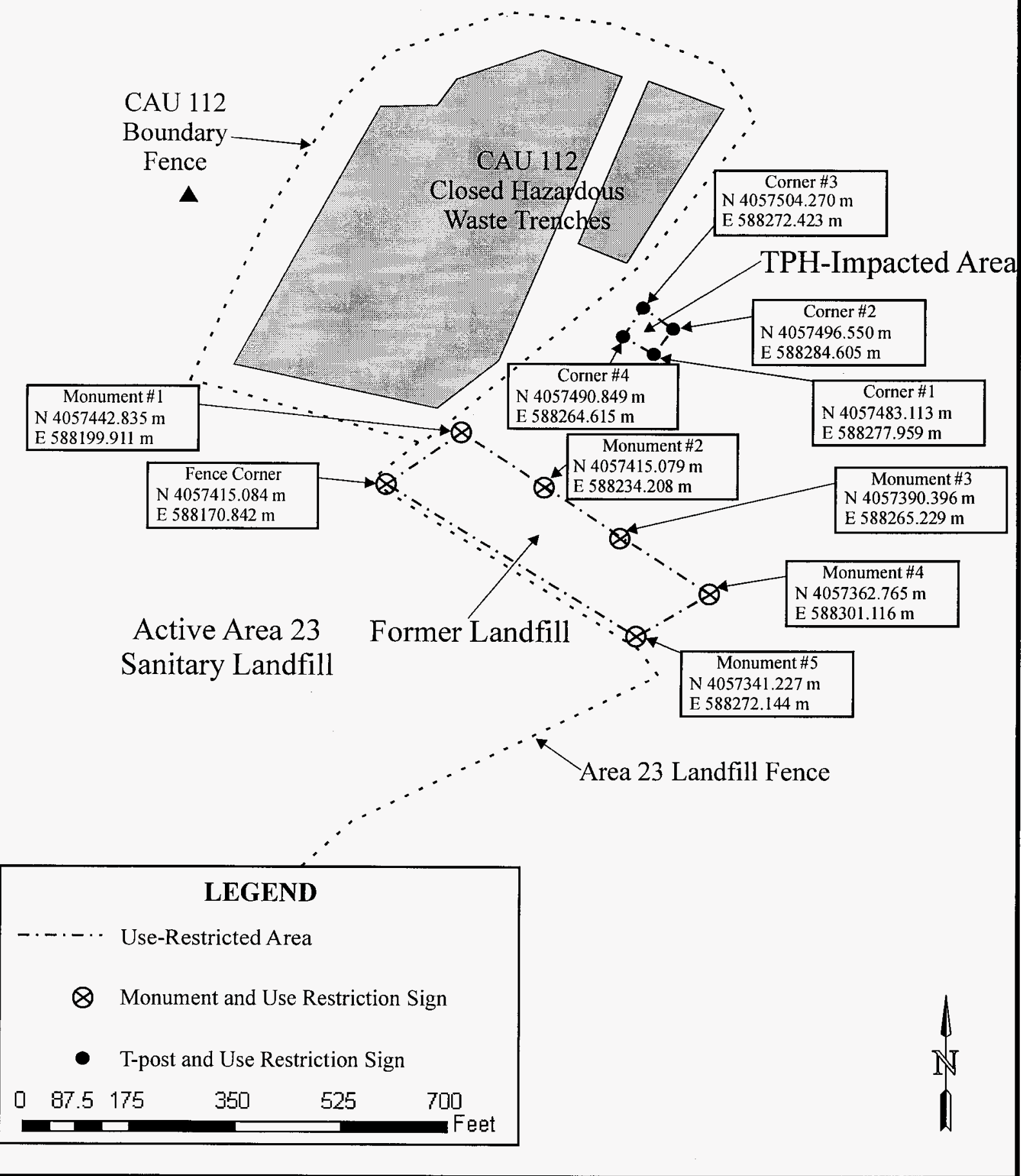

CAU 140, CAS 23-17-01 UR 


\section{APPENDIX H}

\section{SITE CLOSURE PHOTOGRAPHS}


Closure Report - CAU 140

Section: Appendix H

Revision: 0

Date: August 2005

THIS PAGE INTENTIONALLY LEFT BLANK 


\section{PHOTOGRAPHIC LOG}

\begin{tabular}{|c|c|c|l||}
\hline $\begin{array}{c}\text { Photograph } \\
\text { Number }\end{array}$ & \multicolumn{1}{|c||}{ Date } & $\begin{array}{c}\text { CORRECTIVE } \\
\text { ACTION SITE }\end{array}$ & \multicolumn{1}{|c||}{ DescriPTION } \\
\hline 1 & $12 / 13 / 2004$ & $05-08-01$ & Before closure activities \\
\hline 2 & $04 / 07 / 2005$ & $05-08-01$ & After closure activities \\
\hline 3 & $12 / 13 / 2004$ & $05-08-02$ & Before closure activities \\
\hline 4 & $02 / 09 / 2005$ & $05-08-02$ & After closure activities \\
\hline 5 & $12 / 13 / 2004$ & $05-17-01$ & Before closure activities \\
\hline 6 & $04 / 21 / 2005$ & $05-17-01$ & After closure activities \\
\hline 7 & $12 / 13 / 2004$ & $05-19-01$ & Before closure activities \\
\hline 8 & $02 / 15 / 2005$ & $05-19-01$ & After closure activities \\
\hline 9 & $12 / 13 / 2004$ & $05-23-01$ & Before closure activities \\
\hline 10 & $04 / 07 / 2005$ & $05-23-01$ & After closure activities \\
\hline 11 & $12 / 13 / 2004$ & $05-35-01$ & No Further Action site \\
\hline 12 & $01 / 26 / 2005$ & $05-99-04$ & Before closure activities \\
\hline 13 & $02 / 11 / 2005$ & $05-99-04$ & After closure activities \\
\hline 14 & $12 / 13 / 2004$ & $22-99-04$ & Before closure activities \\
\hline 15 & $02 / 10 / 2005$ & $22-99-04$ & After closure activities \\
\hline 16 & $12 / 13 / 2004$ & $23-17-01$ & After closure activities \\
\hline 17 & $04 / 07 / 2005$ & $23-17-01$ & After closure activities \\
\hline 18 & $04 / 07 / 2005$ & $23-17-01$ & After closure activities \\
\hline
\end{tabular}


Closure Report - CAU 140

Section: Appendix $\mathrm{H}$

Revision: 0

Date: August 2005

THIS PAGE INTENTIONALLY LEFT BLANK 


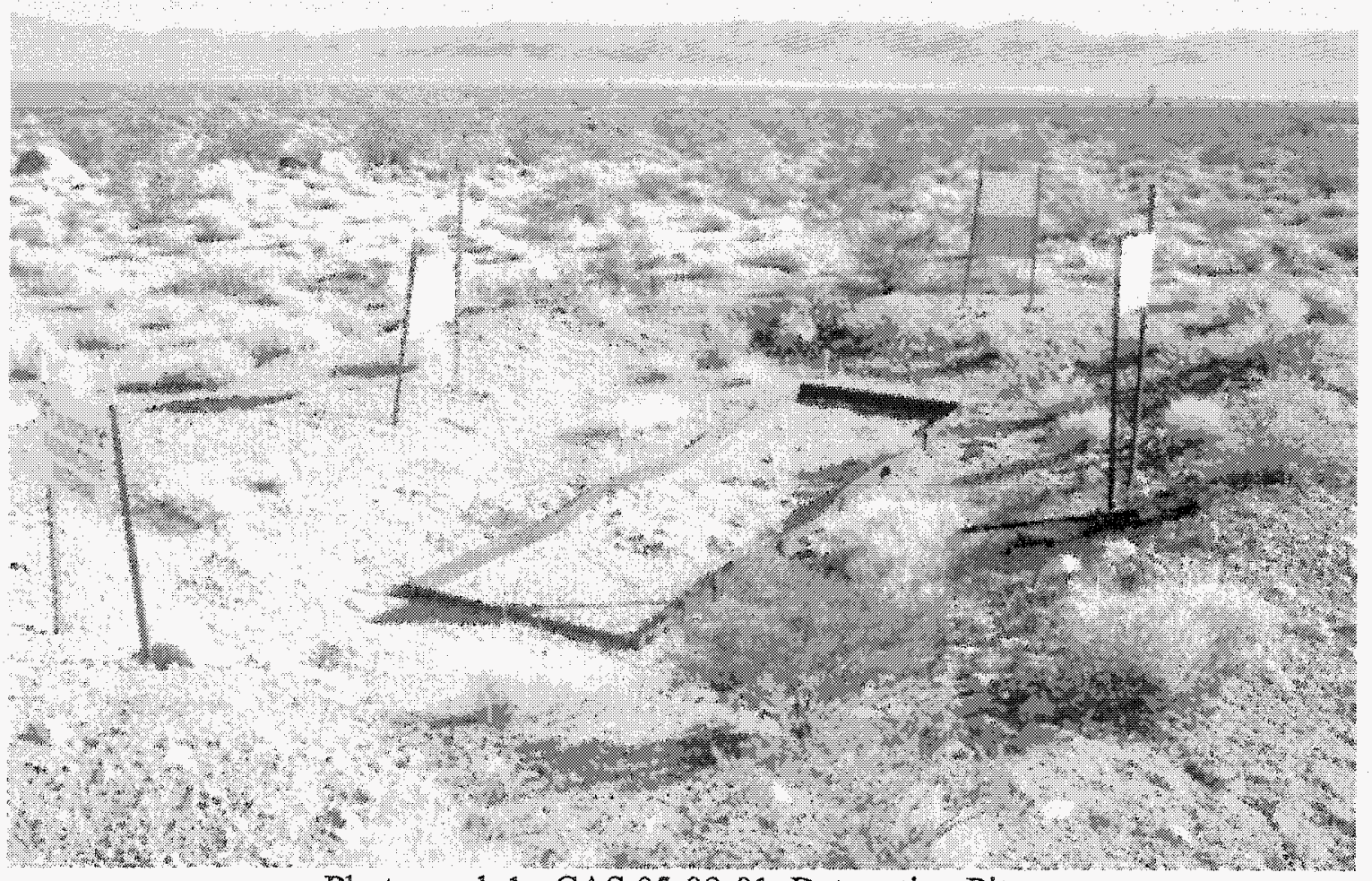

Photograph 1: CAS 05-08-01, Detonation Pits,

Before closure activities, 12/13/2004

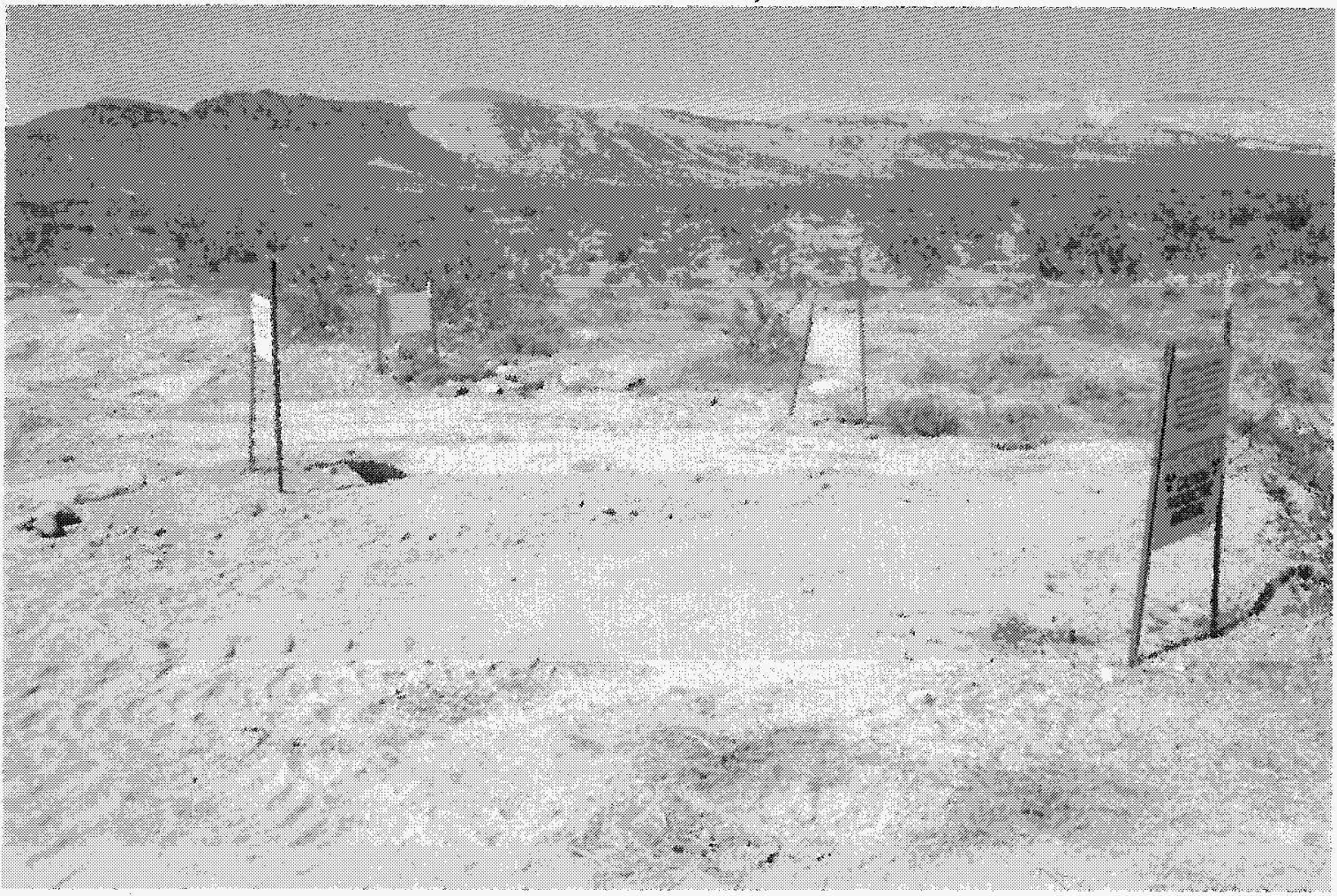

Photograph 2: CAS 05-08-01, Detonation Pits, After closure activities, 04/07/2005 


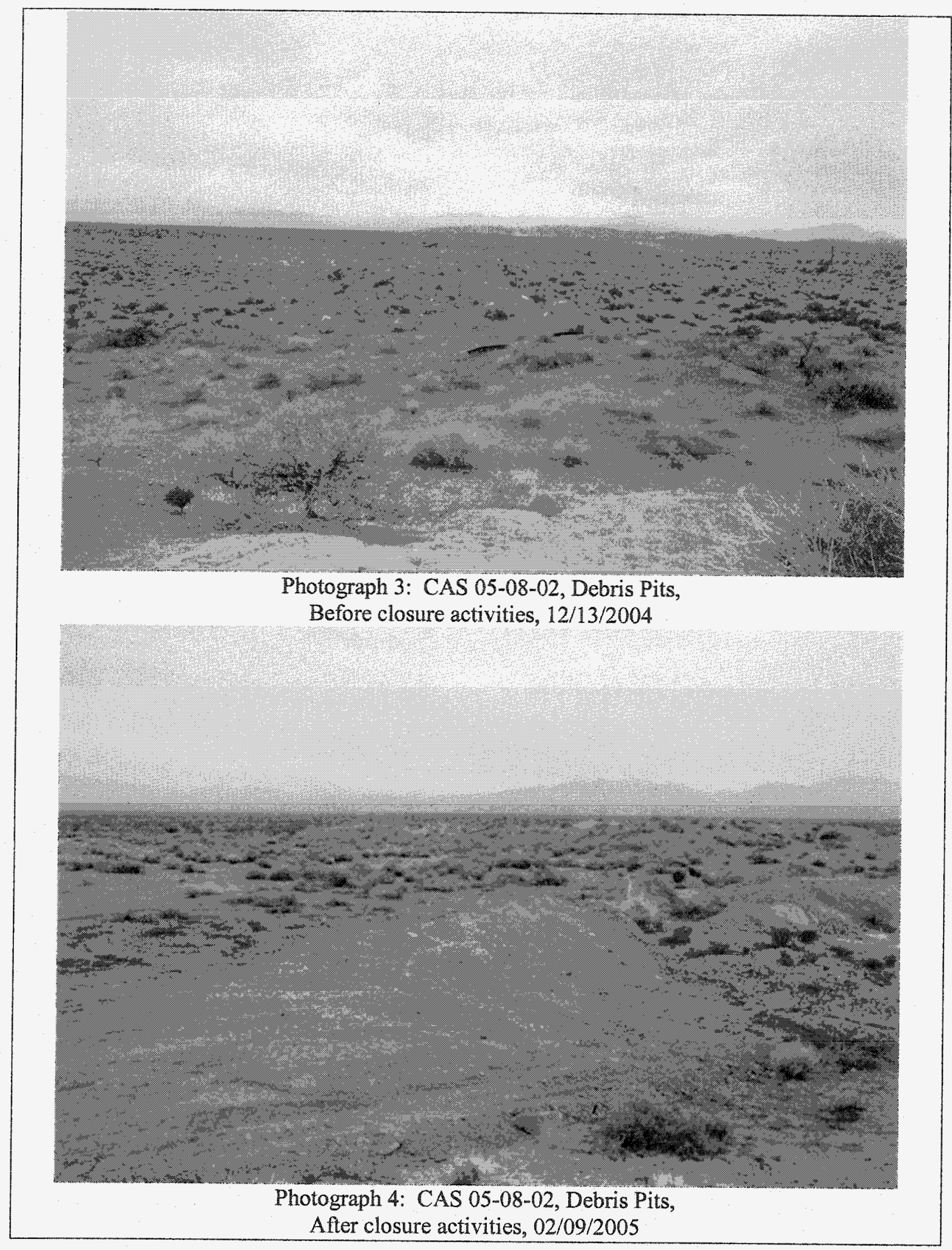




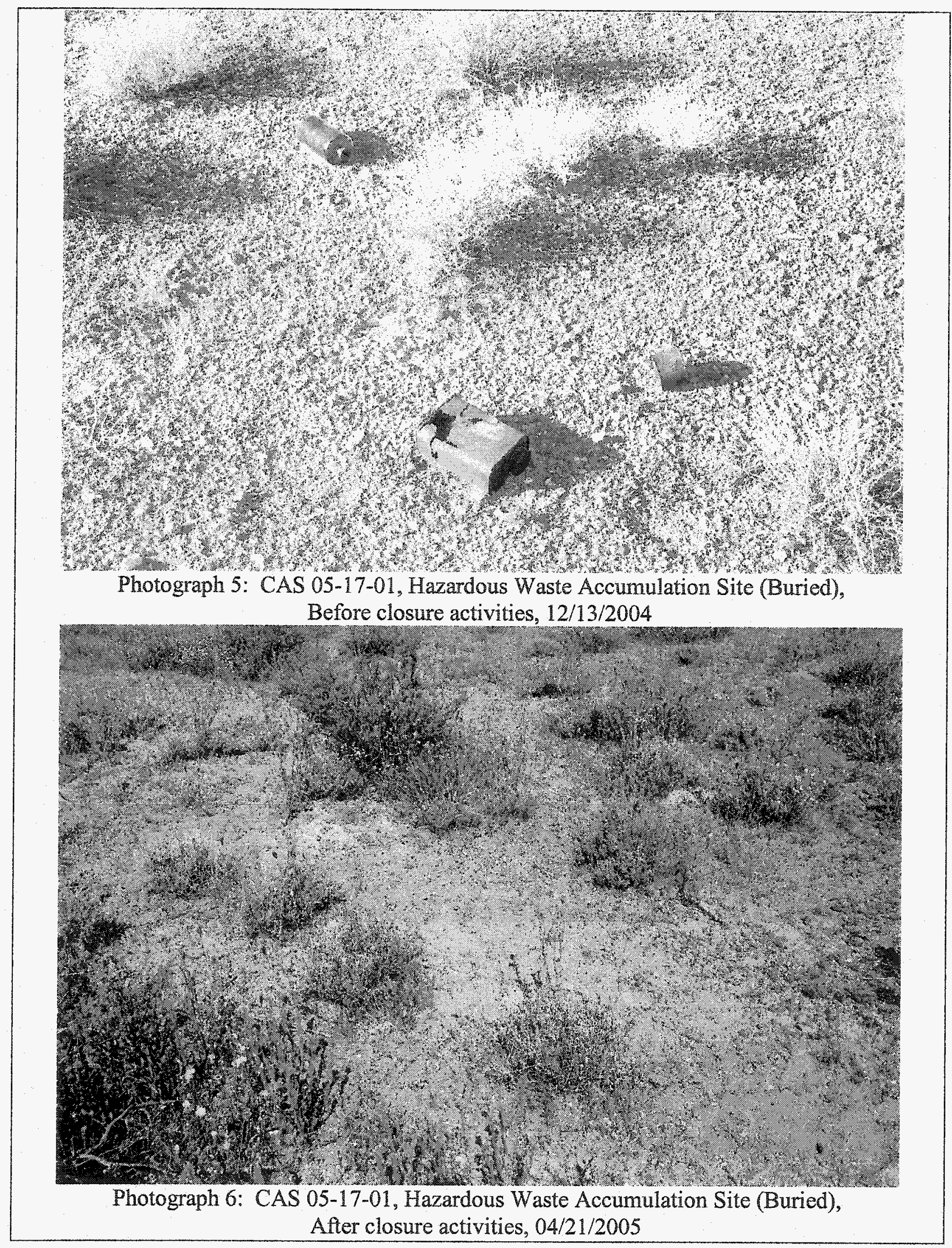




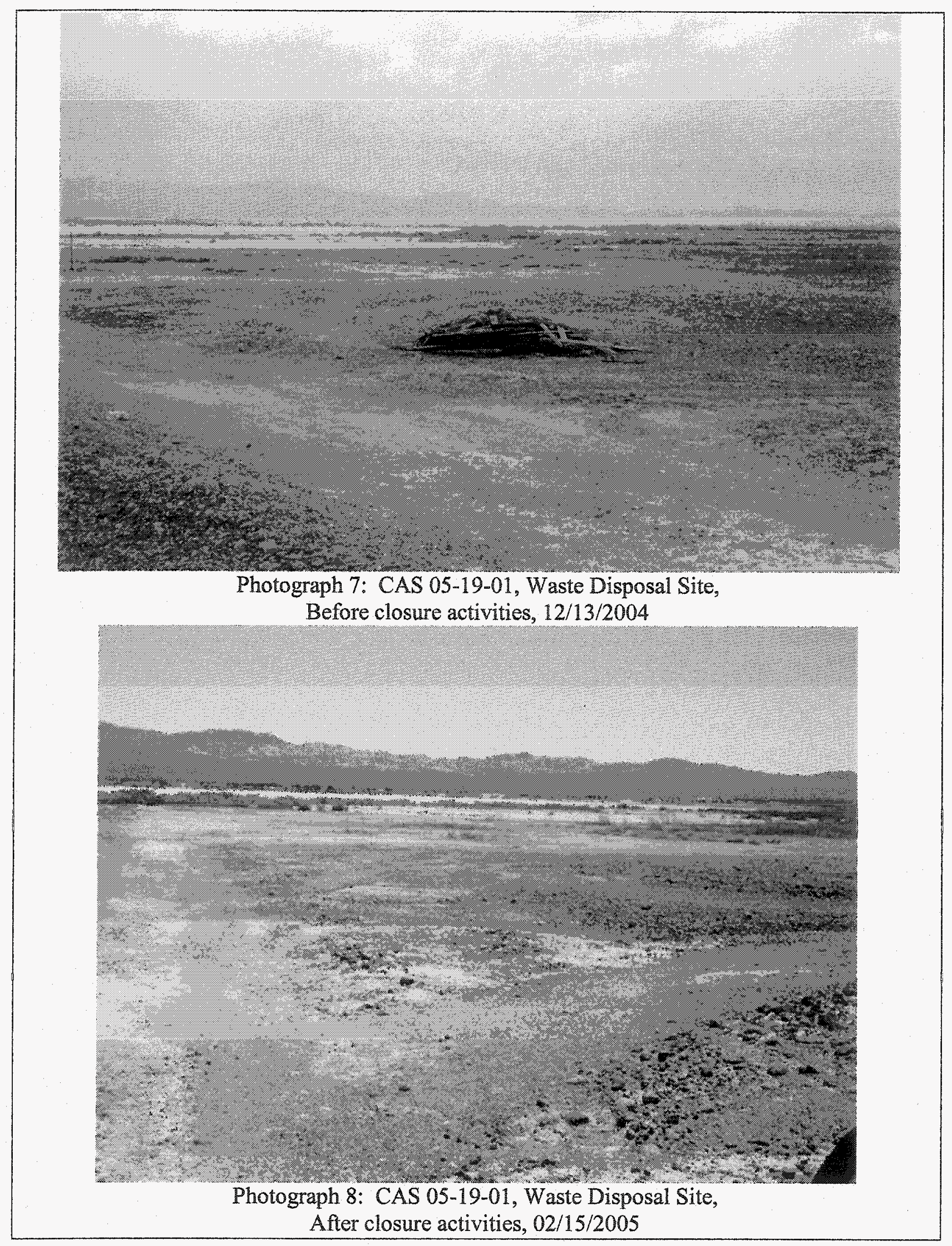




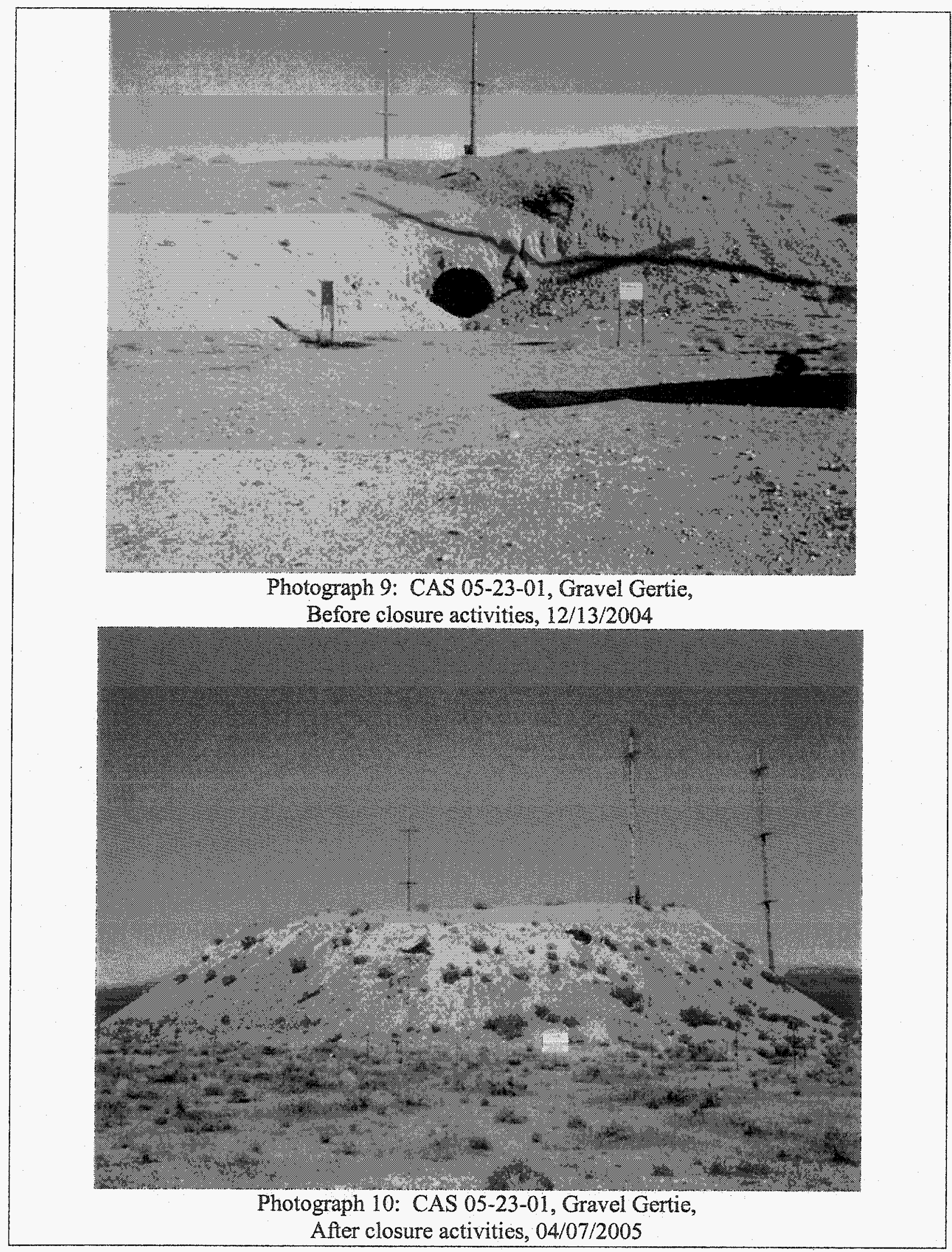




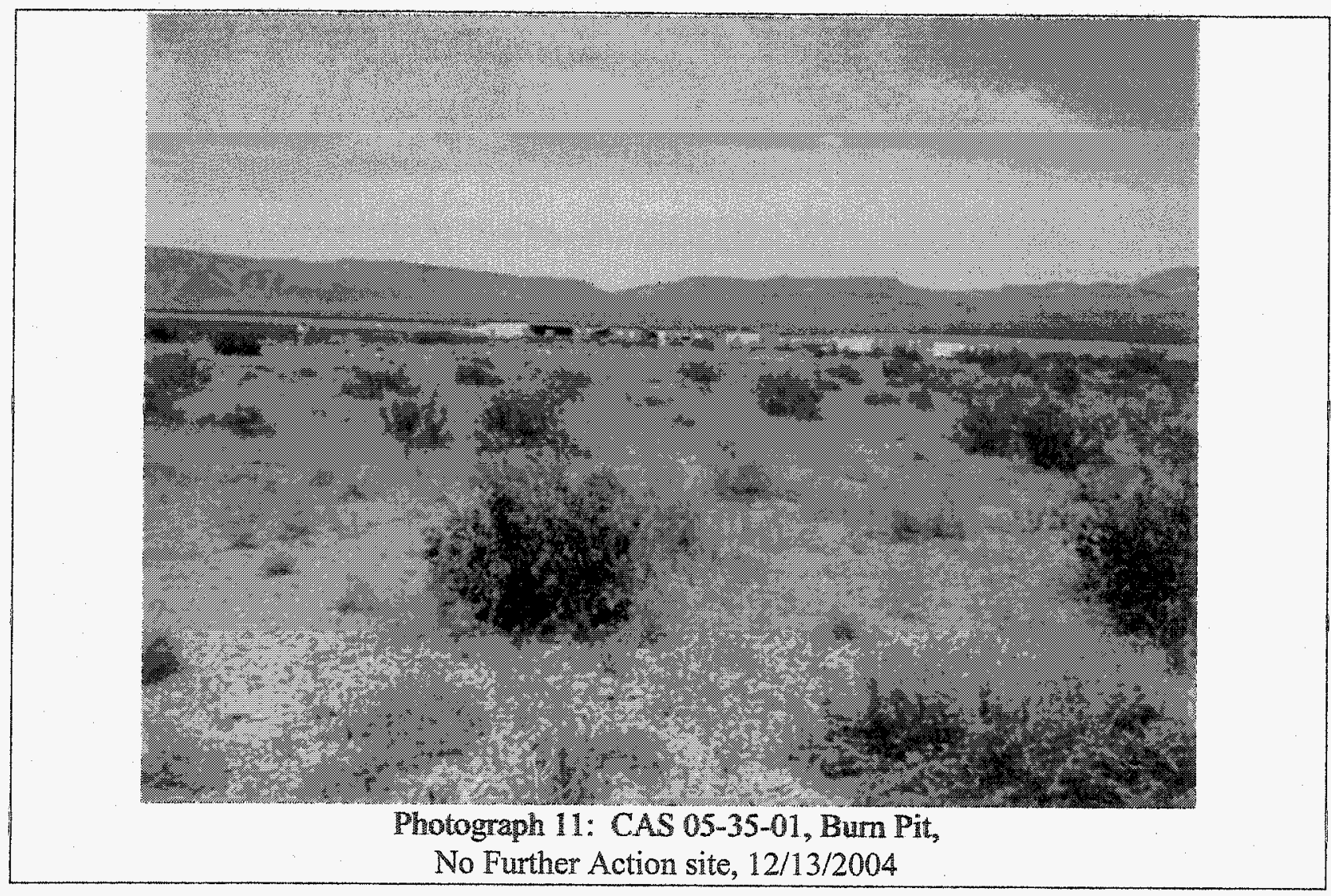




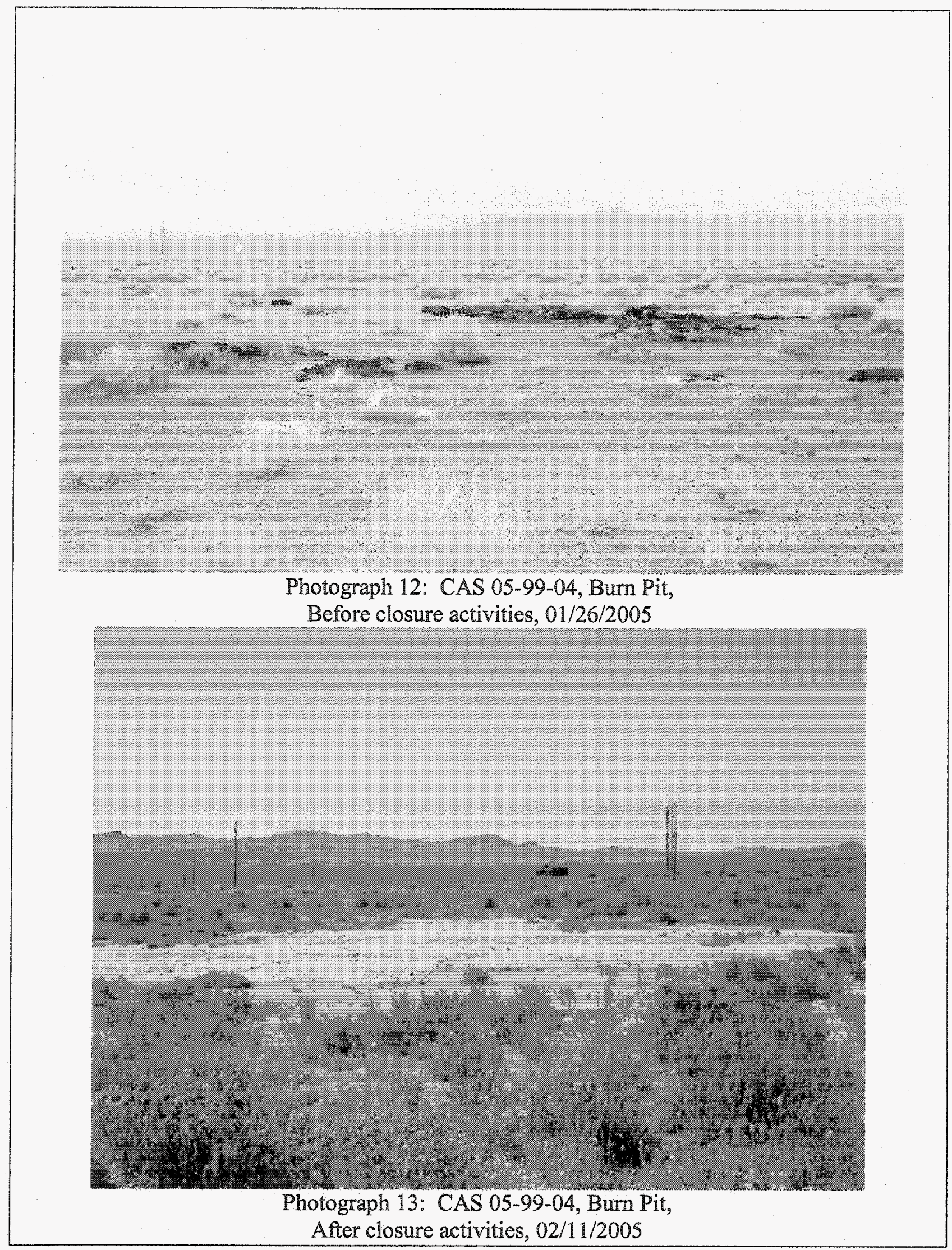




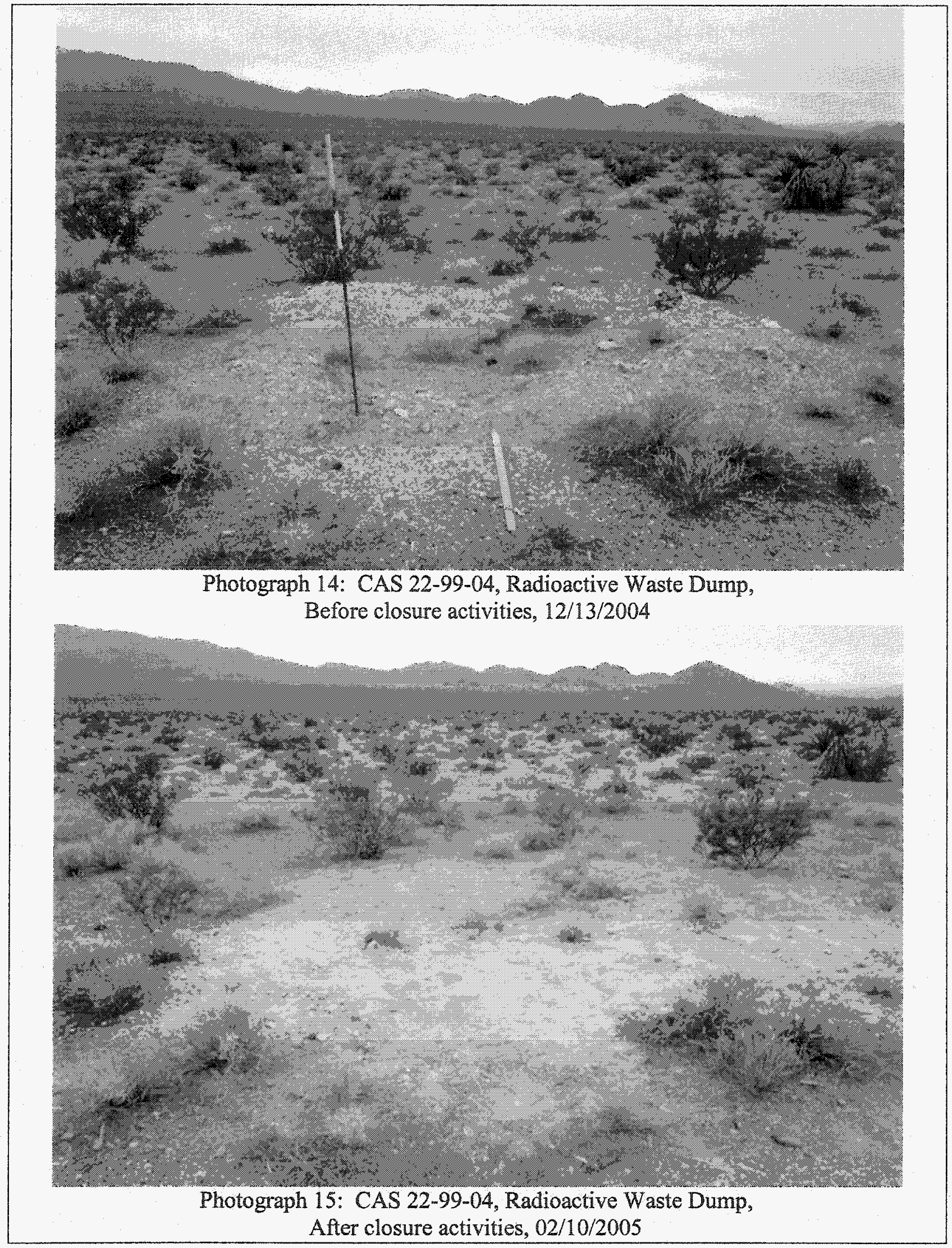




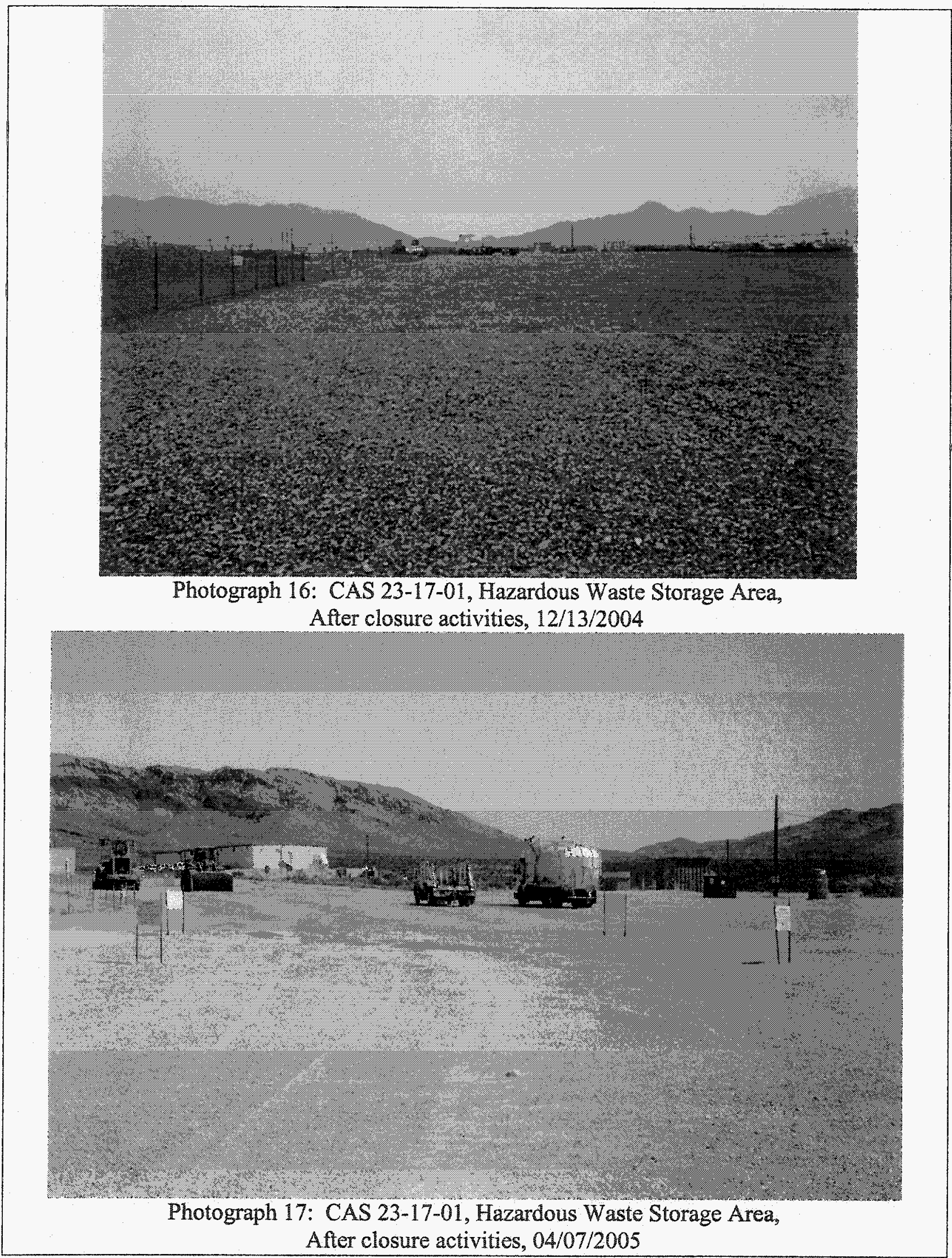


Closure Report - CAU 140

Section: Appendix H

Revision: 0

Date: August 2005

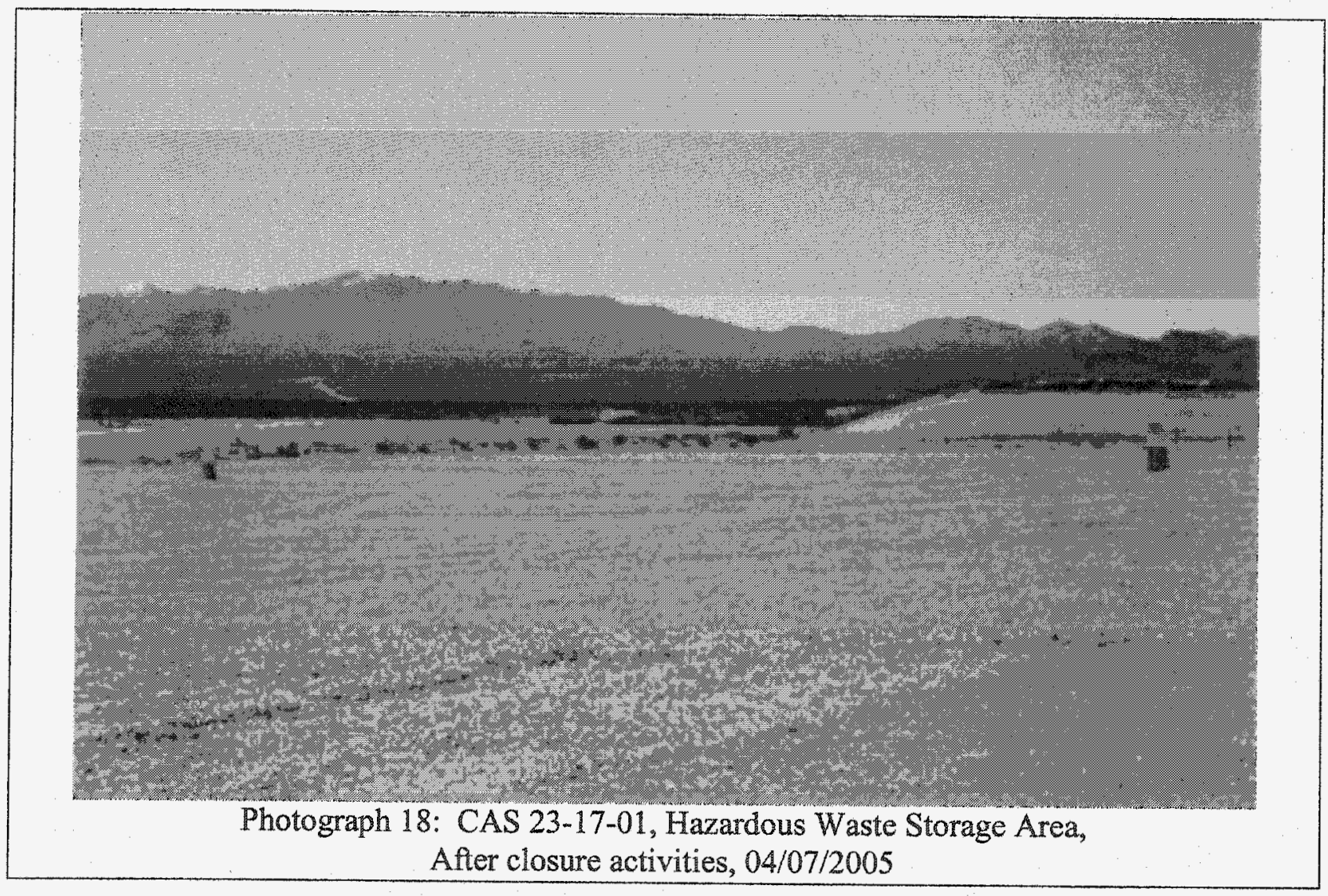




\section{APPENDIX I}

\section{NEVADA ENVIRONMENTAL RESTORATION PROJECT DOCUMENT REVIEW SHEET}


Closure Report - CAU 140

Section: Appendix I

Revision: 0

Date: August 2005

THIS PAGE INTENTIONALLY LEFT BLANK 


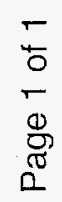
过

늘

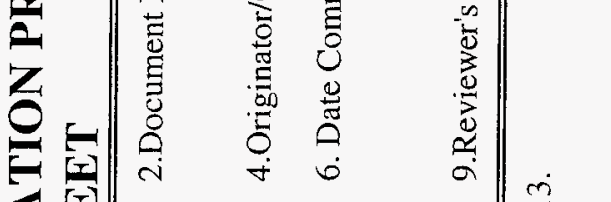

3

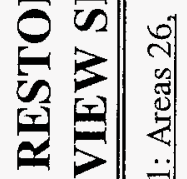

는

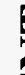

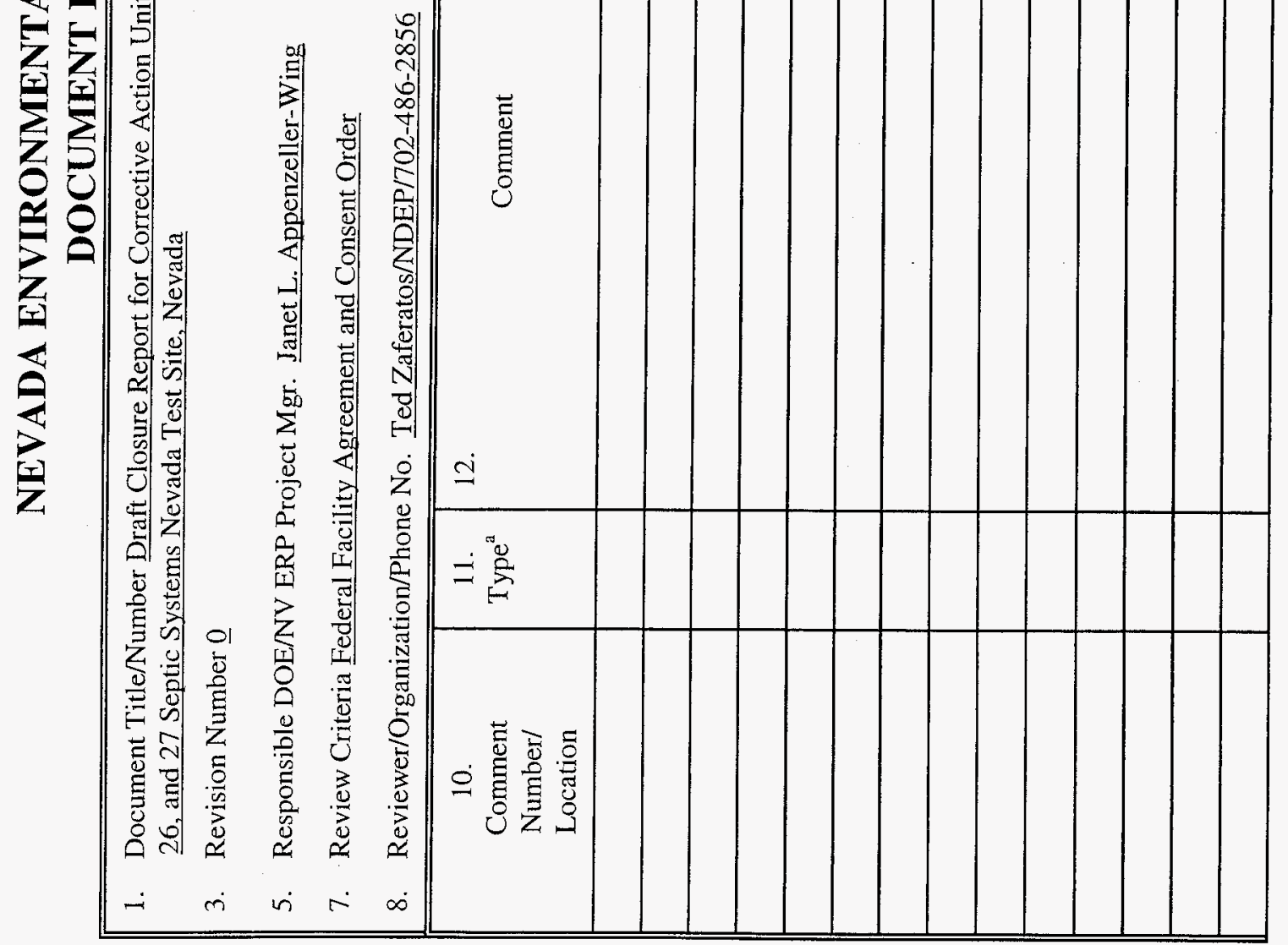

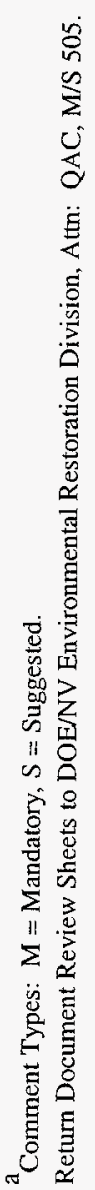


Closure Report - CAU 140

Section: Appendix J

Revision: 0

Date: August 2005

\section{APPENDIX J}

\section{NATIONAL ENVIRONMENTAL POLICY ACT CHECKLIST}


Closure Report - CAU 140

Section: Appendix J

Revision: 0

Date: August 2005

THIS PAGE INTENTIONALLY LEFT BLANK 


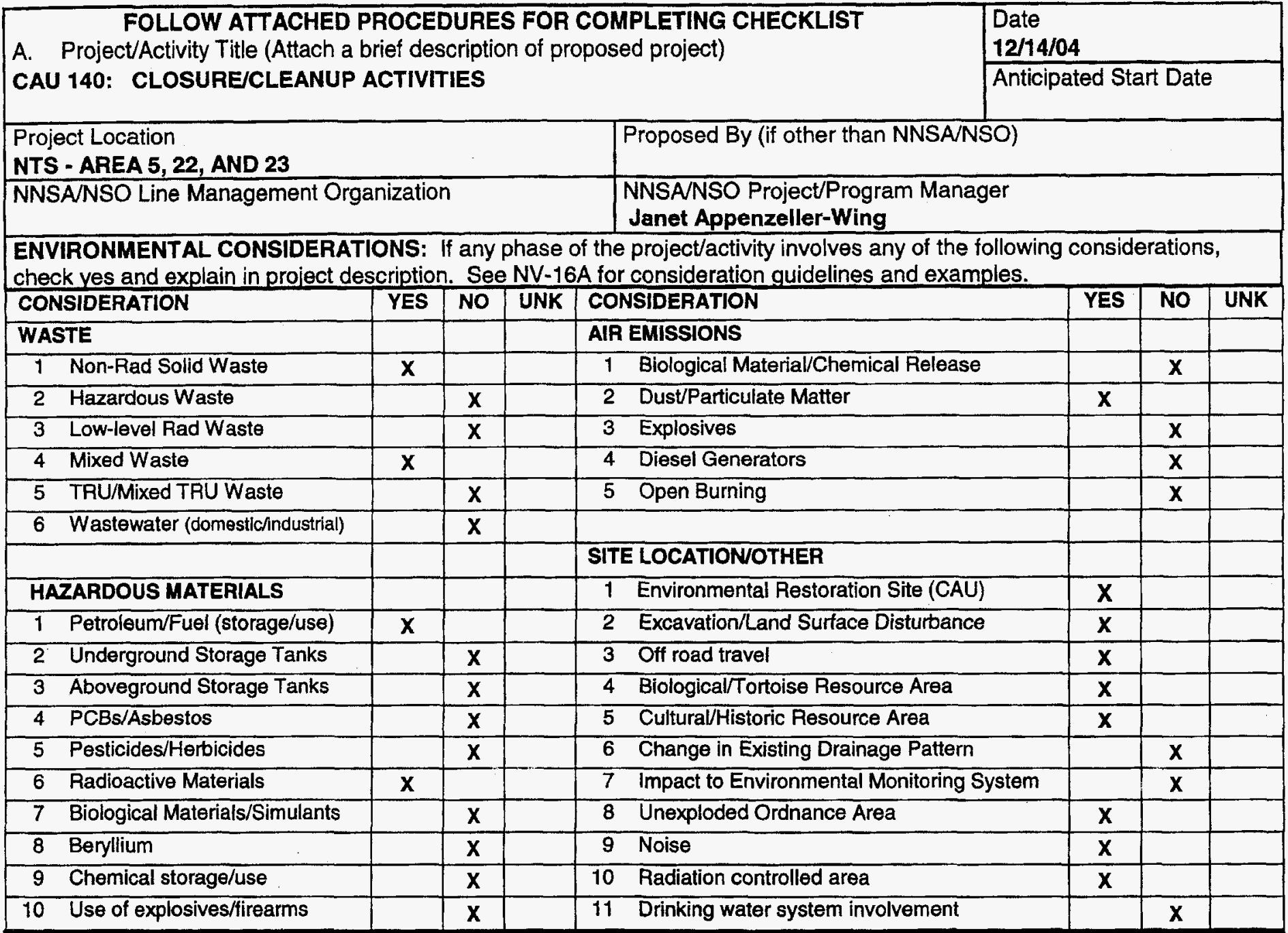

7.7.7.7.

B. Is the project/activity included in the final NTS EIS and the ROD or other NEPA document? Yes $\quad \mathrm{X}$ (complete Sections C, D, and E) No ___ (complete Sections D, E, and F)

C. This project/activity is included in the NTS EIS/ROD (or other NEPA document) under the following section and page no.: NTS/EIS Volume 1, Appendix A, A.3.1.3 - Environmental Restoration Program - Industrial Sites Project

D. Does the proposed project/activity require any local, state, or federal permits or notifications?

Yes $\underline{X}$ No

E. If, based on the project description and the preliminary environmental considerations noted above, the proposed action fits within a class of action listed In Subpart D of 10 CFR 1021, write in the space below, the paragraph number and short title from the appropriate table of contents of Subpart D, Appendix B, C, or D, for a CX, EA, or EIS. If the proposed action does not fit within any class of action, write "Not Listed" below.

F. NEPA COMPLIANCE OFFICER DETERMINATION OR RECOMMENDATION:

I have determined that the proposed activity as described in item $A$ above, has been adequately addressed in the document cited in item $E$ and meets all requirements for categorical exclusion. No further analysis or documentation is required pursuant to NEPA.

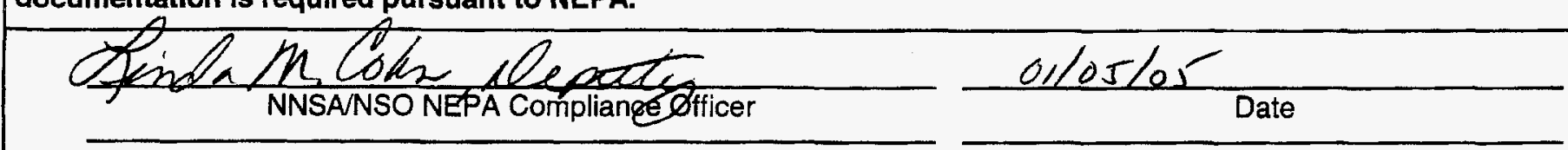




\section{CAU 140: CLOSURE/CLEANUP ACTIVITIES}

\section{Project Description}

Corrective Action Unit (CAU) 140 consists of nine Corrective Action Sites (CASs), located at in Areas 5, 22, and 23 of the Nevada Test Site (NTS). CAU 140 sites will be closed by removing debris, contaminated soil and implementing use restrictions. Each CAS is briefing described below.

\section{AREA 5}

\section{CAS 05-08-01, Detonation Pits}

This site consists of miscellaneous surface debris and two backfilled detonation pits. Soil at one of the detonation pits is contaminated with lead and uranium-235. The site will be closed by removing the surface debris and removing and disposing of a limited amount of soil as mixed waste.

\section{CAS 05-08-02, Debris Pits}

The site consists of miscellaneous surface debris and an evaporation basin. The surface debris will be removed and disposed.

\section{CAS 05-17-01, Hazardous Waste Accumulation Site (Buried)}

The site consists of a small mound with minimal staining and surface debris. The surface debris will be removed and disposed.

\section{CAS 05-19-01. Waste Disposal Site}

The site consists of three separate areas of surface debris. The debris will be removed and disposed.

\section{CAS 05-23-01, Gravel Gertie}

The site consists of the Gravel Gertie and surface debris. The debris will be removed and disposed and a use restriction fence will be placed around the Gravel Gertie.

\section{CAS 05-35-01, Burn Pit}

The site consists of two surface burn stains. No work will be performed at this site.

\section{CAS 05-99-04, Burn Pit}

The site consists of three separate burn areas with surface debris. The debris will be removed and disposed.

\section{AREA 22}

\section{CAS 22-99-04, Radioactive Waste Dump}

The site consists of a bermed area with deteriorating sand bags. The sand bags will be removed and disposed.

\section{AREA 23}

CAS 23-17-04. Hazardous Waste Storage Area

The site consists of a former hazardous waste storage facility and a landfill with buried debris. A use restriction fence will be placed around the area.

\section{Environmental Considerations}

Waste

1. Non-Radioactive Solid Waste will be removed from several of the CASs as a best management practice. This includes scrap metal, wood, and other non-hazardous debris.

4. Mixed waste may be generated at CAS 05-08-01 as a small amount of soil is to be excavated that is impacted with lead and potentially Thorium. 


\section{Hazardous Materials}

1. Heavy equipment on site will use petroleum fuel. No fuel will be stored on site outside of the equipment. Absorbent pads will be used if equipment appears to be leaking petroleum.

6. The contaminated soil at CAS 05-08-01 is expected to be mixed waste for lead and radiological constituents. The soil will be removed and placed in 55 gallon steel drums, managed as mixed waste, and disposed of off-site at a licensed Treatment, Storage and Disposal facility.

\section{Air Emissions}

2. Dust/Particulate Matter will be controlled during soil excavation by the use of water sprays.

\section{Site Location/Other}

1. Environmental Restoration Site: These sites are included in the Federal Facility Agreement and Consent Order between the Department of Energy and the state of Nevada as part of Corrective Action Unit 140. (See Project Description).

2. Excavation will occur at CAS 05-08-01 to remove approximately 2 cubic yards of soil. Soil will be removed by using either a backhoe or front-end loader.

3. Off-Road Travel: All sites will be accessed by using existing unimproved roads.

4. Several of the sites are located in a Biological/Tortoise Resource Area. A biological pre-activity survey will be conducted prior to starting field activities.

5. Cultura//Historic Resource Area: CAS 05-23-01 is located at the Gravel Gertie which is of historical interest. A cultural survey of the site has been performed and determined that the approved closure activities will not affect the cultural significance of the site. Closure work will include minor housekeeping and the installation of a fence around the structure.

8. Unexploded Ordnance Area: CAS 05-08-01 is a former detonation pit area and the area will be screened for UXO prior to initiating activities

9. Elevated noise levels may result from the operation of a backhoe and/or loader equipment. Personnel not directly involved with operation of this equipment will be kept back at least 15 feet while equipment is in use. The equipment operator will follow the instructions as directed in the Site Specific Health and Safety Plan.

10. CAS 05-23-01 is adjacent to a posted Underground Radiation Area. Actual site work will not be performed inside the posted area. CAS 05-08-01 is located in a posted Radiological Materials Area. 
Closure Report - CAU 140

Section: Library Distribution List

Revision: 0

Date: August 2005

\section{LIBRARY DISTRIBUTION LIST}


Closure Report - CAU 140

Section: Library Distribution List

Revision: 0

Date: August 2005

THIS PAGE INTENTIONALLY LEFT BLANK 


\section{LIBRARY DISTRIBUTION LIST}

U.S. Department of Energy

National Nuclear Security Administration

Nevada Site Office

Technical Library

P.O. Box 98518, M/S 505

Las Vegas, NV 89193-8518

U.S. Department of Energy

Office of Scientific and Technical Information

P.O. Box 62

Oak Ridge, TN 37831-0062

Southern Nevada Public Reading Facility c/o Nuclear Testing Archive

P.O. Box 98521, M/S 400

Las Vegas, NV 89193-8521

Manager, Northern Nevada FFACO

Public Reading Facility

c/o Nevada State Library \& Archives

Carson City, NV 89701-4285
1 (Uncontrolled)

1 (Uncontrolled, electronic copy)

2 (Uncontrolled, electronic copies)

1 (Uncontrolled, electronic copy) 
Revision: 0

Date: August 2005

THIS PAGE INTENTIONALLY LEFT BLANK 